WSRC-RP-95-237

Revision 0

\title{
Groundwater Model Recalibration and \\ Remediation Well Network Design \\ at the \\ F-Area Seepage Basins (U)

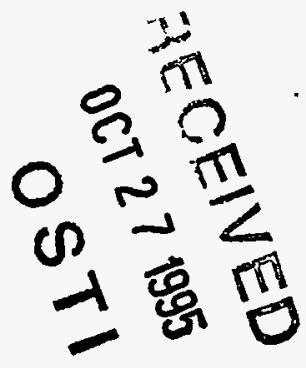

Unclassified

Does Not Contain Unclassified Controlled Nuclear Information (UCNI)

April 1995

\begin{abstract}
William R. Sadler
Site Geotechnical Services Department

Westinghouse Savannah River Company

Savannahi River Site

Aiken, SC 29808

PREPARED FOR THE U.S. DEPARTMENT OF ENERGY UNDER CONTRACT DE-ACO9-89R18035

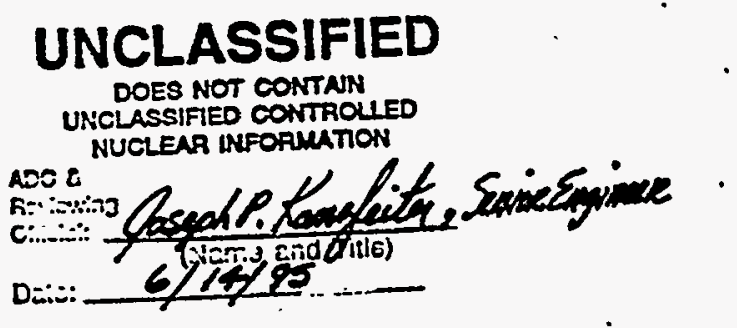




\section{Disclaimer}

This report was prepared as an account of work sponsored by an agency of the United States Government. Neither the United States Government nor any agency thereof, nor any of their employees, makes any warranty, expressed or implied, or assumes any legal liability or responsibility for the accuracy, completeness, or usefulness of any information, apparatus, product, or process disclosed, or represents that its use would not infringe privately owned rights. Reference herein to any specific commercial product, process, or service by the trade name, trademark, manufacturer, or otherwise, does not necessarily constitute or imply its endorsement, recommendation, or favoring by the United States Government or any agency thereof. The views and opinions of authors expressed herein do no necessarily state or reflect those of the United States Government or any agency thereof. 


\section{DISCLAIMER}

Portions of this document may be illegible in electronic image products. Images are produced from the best available original document. 
Document: WSRC-RP-95-237, Revision 0

Title: Groundwater Model Recalibration and Remediation Well Network Design at the F-Area Seepage Basins (U)

Author:

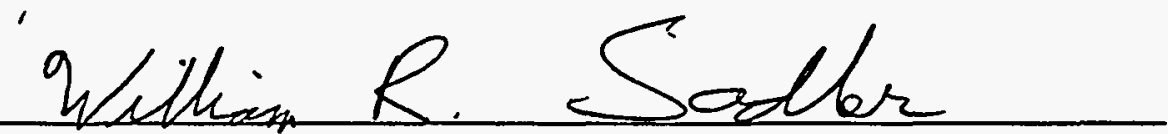

William R. Sadler

$4-3-95$

Fate and Transport Analysis Group

Site Geotechnical Services Department

Engineering and Construction Services Department

Technical Reviewer:

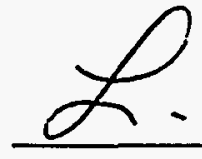<smiles>CC1(C)CCCC1(C)C</smiles>

L. Larry Hamm<smiles>[Mg][V]</smiles>

Engineering, Modeling, and Simulation Group

Applied Technology Section

Savannah River Technology Center

Approval:

William F. Swift

$\omega 7$

Manager, Fate and Transport Analysis Group

$4-3-95$

Date

\section{Date}




\section{TABLE OF CONTENTS}

EXECUTTVE SUMMARY xi

ACKNOWLEDGMENTS. xii

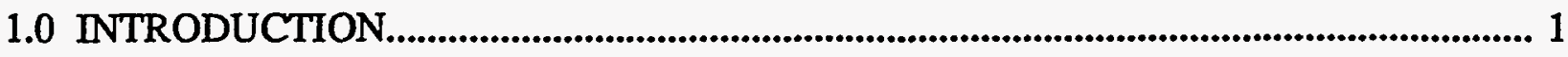

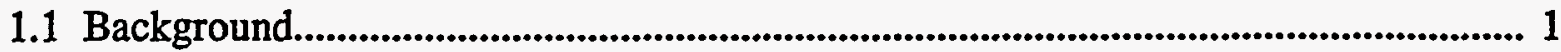

1.2 Objective and Approach.......................................................................................... 1

1.3 Hydrogeology................................................................................................................ 2

1.3.1 General.............................................................................................................. 2

1.3.2 Estimate of Hydraulic Conductivity....................................................................... 2

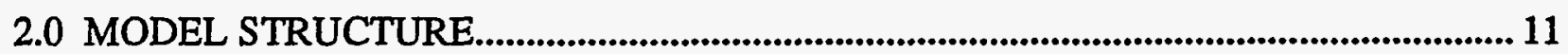

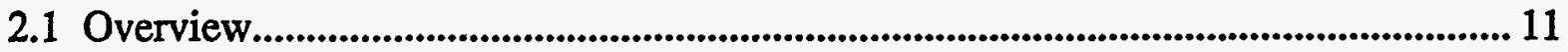

2.2 Horizontal Discretization..................................................................................................... 11

2.3 Vertical Discretization.................................................................................................... 11

2.4 Boundary Conditions............................................................................................................... 13

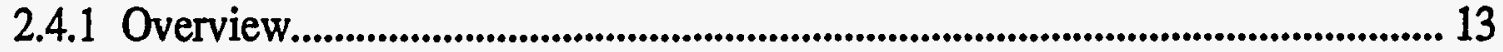

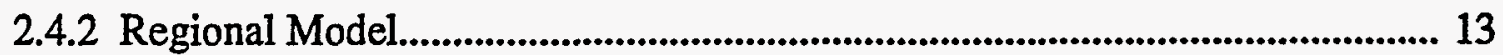

2.4.3 Local Model..................................................................................................... 14

2.5 Model Code and Version....................................................................................................... 16

3.0 MODELING APPROACH AND PROCESS.......................................................... 17

3.1 Modeling Approach.............................................................................................................. 17

3.2 Calibration Process................................................................................................................. 19

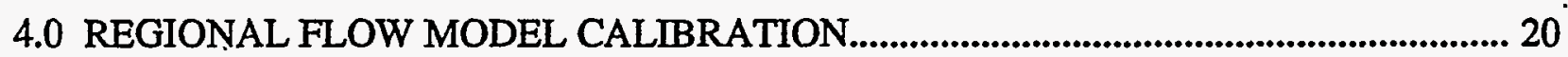

4.1 Conceptual Model.................................................................................................................... 20

4.2 Calibration Results......................................................................................................... 20

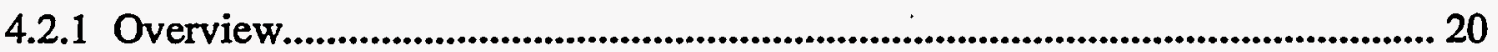

4.2.2 Hydraulic Conductivity Values.......................................................................... 21

4.2.3 Connection of Aquifer Zone $\mathrm{IIB}_{1}$ (Barnwell/McBean) to Fourmile Branch......... 22

4.2.4 Congaree and Upper Three Runs Creek............................................................. 24

4.2.5 Recharge Rates.......................................................................................................... 25

4.2.6 Changes in Layer Thickness from GeoTrans (1993)............................................. 25

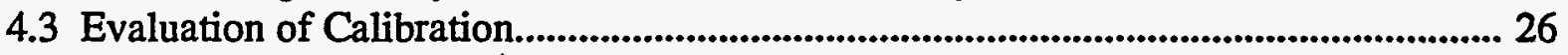

4.3.1 Hydraulic Head and Hydraulic Gradients........................................................... 26

4.3.2 Particle Tracking........................................................................................... 27

4.3.3 Water Flux to Fourmile Branch......................................................................... 28

4.4 Regional Model with Seepage Basins Operational........................................................ 28 


\section{TABLE OF CONTENTS (Continued)}

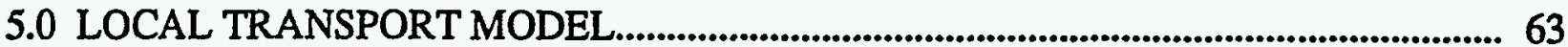

5.1 Transport Model Setup........................................................................................................ 63

5.2 Transport Model Results.................................................................................................... 63

5.3 Transport Simulations for 1992 - 1997.......................................................................... 65

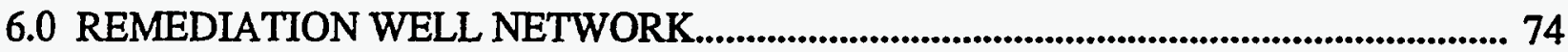

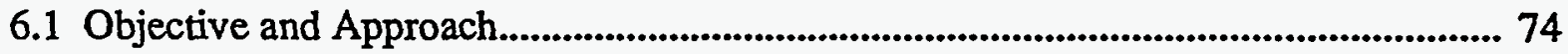

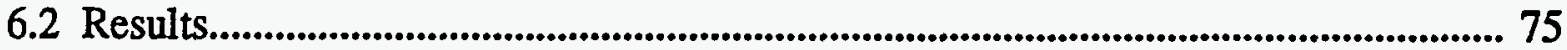

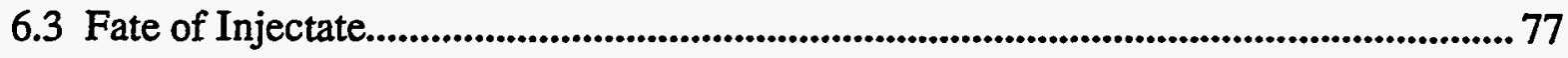

7.0 RECOMMENDATIONS FOR FURTHER MODELING EFFORTS.................................. 93

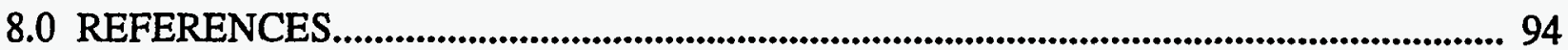

APPENDIX 1. COMPARISON OF HYDRAULIC HEADS FROM REGIONAL AND LOCAL MODEL............................................................... 97

APPENDIX 2. CALIBRATION REȘULTS FOR TOTAL MODEL AREA..............................101

APPENDIX 3. SIMULATED TRITIUM CONCENTRATIONS

FOR YEARS 1991, 1988, 1986, 1978, AND 1970......................................... 114. 


\section{LIST OF FIGURES}

1.1 Map of the study area.

1.2 Hydrostratigraphic nomenclature used from Aadland, 1990.......................................... 4

1.3 Hydraulic head distribution of Aquifer Zone $\mathrm{IBB}_{2}$ (Water Table) near the F-Area Seepage Basins for second quarter of 1991.

1.4 Hydraulic head distribution of Aquifer Zone IIB $_{1}$ (Barnwell/McBean) near the F-Area Seepage Basins for second quarter of 1991.

1.5 Hydraulic head distribution of Aquifer Unit IIA (Congaree) near the F-Area

Seepage Bassins for second quarter of 1991

1.6 Location of test wells and observation wells for F-Area multiple well tests

1.7 Location of test wells and observation wells for $\mathrm{H}$-Area multiple well tests

2.1 Regional model grid with local model grid outlined....................................................... 12

3.1 Section of the regional and local models which were modified in this modeling effort.

4.1 Nonvolatile Beta Activities in Aquifer Zone IB $_{1}$.(Barnwell/MacBean) at the F-Area Seepage Basins, second quarter, 1994 with the location of test well FSB-OPC.

4.2 Cross section from well clusster FSB-79, through Fourmile Branch, to well cluster FSB-115.

4.3 Original model thickness of Confining Zone $\mathrm{IBB}_{1}$. $\mathrm{IB}_{2}$ (Tan Clay) (in feet), and the area where the thickness was modified.

4.4 Original model thickness of Confining Zone IIB-IIB (Green Clay) (in feet), for the area where the thickness was modified.

4.5 Simulated hydraulic head distribution of Aquifer Zone $\mathrm{IB}_{1} \cdot \mathrm{IB}_{2}$ (Water Table); from the regional model near the F-Area Seepage Basins.

4.6 Simulated hydraulic head distribution for Aquifer Zone $\mathrm{IB}_{1}$ (Barnwell/McBean); from the regional model near the F-Area Seepage Basins.

4.7 Simulated hydraulic head distribution for Aquifer Unit III (Congaree); from the regional model near the F-Area Seepage Basins.

4.8 Difference in hydraulic head values between the current modeling effort and the model in GeoTrans (1993) for Aquifer Zone $\mathrm{IBB}_{2}$ (Water Table) near the H-Area Seepage Basins..

4.9 Difference in hydraulic head values between the current modeling effort and the model in GeoTrans (1993) for Aquifer Zone IBB $_{1}$ (Barnwell/McBean) near the H-Area Seepage Basins.

4.10 Difference in hydraulic head values between the current modeling effort and the model in GeoTrans (1993) for Aquifer Unit IIA (Congaree).

4.11 Areal distribution of hydraulic head residuals for Aquifer Zone $\mathbb{I B}_{2}$ (Water Table) near F-Area Seepage Basins..

4.12 Areal distribution of hydraulic head residuals for Aquifer Zone $\mathrm{IB}_{1}$ (Barnwell/McBean) near F-Area Seepage Basins.

4.13 Histogram of hydraulic head residuals in Aquifer Zone $\mathrm{IBB}_{2}$ (Water Table) from the modified model area (columns 1 through 30 ).. 


\section{LIST OF FIGURES (Continued)}

4.14 Histogram of hydraulic head residuals in Aquifer Zone IIB $_{1}$ (Barnwell/McBean) from the modified model area (columns 1 through 30 ). ................................................55

4.15 Comparison of simulated to observed hydraulic heads ( $\mathrm{ft}$ ) in Aquifer Zone $\mathrm{IBB}_{2}$ (Water Table) from the modified model area (columns 1 through 30).............................56

4.16 Comparison of simulated to observed hydraulic heads ( $\mathrm{ft}$ ) in Aquifer Zone $\mathrm{IB}_{1}$ (Barnwell/McBean) from the modified model area (columns 1 through 30)..................57

4.17 Horizontal particle traces within Aquifer Zone $\mathrm{IB}_{2}$ (Water Table) for current conditions (seepage basins not operational).

4.18 Horizontal particle traces within Aquifer Zone $\mathrm{IB}_{1}$ (Barnwell/McBean) for current conditions (seepage basins not operational).

4.19 Horizontal particle traces within Aquifer Zone $\mathrm{IIB}_{2}$ (Water Table) for conditions during operation of seepage basins.

4.20 Horizontal particle traces within Aquifer Zone $\mathrm{IB}_{1}$ (Barnwell/McBean) for conditions during operation of seepage basins.

5.1 Simulated tritium concentrations ( $\mathrm{pCi} / \mathrm{ml}$ ) within Aquifer Zone $\mathrm{IBB}_{2}$ (Water Table) for 1962 .

5.2 Simulated tritium concentrations $(\mathrm{pCi} / \mathrm{ml})$ within Aquifer Zone $\mathrm{IB}_{1}$ (Barnwell/McBean) for 1962.

5.3 Simulated tritium concentrations ( $\mathrm{pCi} / \mathrm{ml}$ ) within Aquifer Zone $\mathrm{IB}_{2}$ (Water Table) for 1992 .

5.4 Simulated tritium concentrations $(\mathrm{pCi} / \mathrm{ml})$ within Aquifer $\mathrm{Z}_{\text {nene }} \mathrm{IB}_{1}$ (Barnwell/McBean) for 1992.

5.5 Tritium activity discharged to Fourmile Branch over time from the vicinity of the F-Area Seepage Basins. Graphs are: 1) calculated from measurements, 2) simulated from this modeling effort, and 3) simulated from modeling effort reported in GeoTrans (1993).

5.6 Simulated tritium concentrations ( $\mathrm{pCi} / \mathrm{ml}$ ) within Aquifer Zone $\mathrm{IB}_{2}$ (Water Table) for 1997.

5.7 Simulated tritium concentrations $(\mathrm{pCi} / \mathrm{ml})$ within Aquifer Zone $\mathrm{IIB}_{1}$ (Barnwell/McBean) for 1997 .

6.1 Well locations within Aquifer Zone $\mathrm{IB}_{2}$ (Water Table) for an early well network scenario.

6.2 Well locations within Aquifer Zone $\mathrm{IB}_{1}$ (Barnwell/McBean) for an early well network scenario.

6.3 Well locations within Aquifer Zone $\mathrm{IB}_{2}$ (Water Table) for the simulated network before the decision to utilize well locations specified in GeoTrans (1993) where possible and before field verification.

6.4 Well locations within Aquifer Zone $\mathrm{IBB}_{1}$ (Barnwell/McBean) for the simulated network before the decision to utilize well locations specified in GeoTrans (1993) where possible and before field verification.

6.5 Well locations within Aquifer Zone $\mathrm{IB}_{2}$ (Water Table) for the final well network.. ....... 82 


\section{LIST OF FIGURES (Continued)}

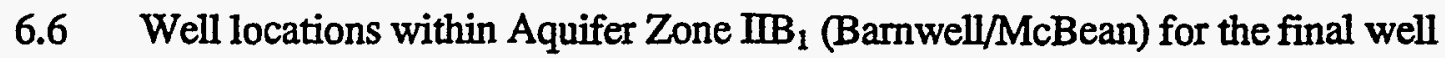
network.

6.7 Simulated hydraulic head distributions for Aquifer Zone $\mathrm{IIB}_{2}$

(Water Table) with the remediation well network active.

6.8 Simulated hydraulic head distributions for Aquifer Zone IIB $_{1}$ (Barnwell/McBean) with the remediation well network active.

6.9 Simulated extraction well capture zones within Aquifer Zone IIB $_{2}$ (Water Table)......... 87

6.10 Simulated extraction well capture zones within Aquifer Zone IIB $_{1}$ (Barnwell/McBean).

6.11 Particle traces from injection wells within Aquifer Zone $\mathrm{IB}_{2}$ (Water Table)................. 89

6.12 Particle traces from injection wells within Aquifer Zone $\mathrm{IBB}_{1}$ (Barnwell/McBean).........90

6.13 Simulated tritium concentration $\left(\mathrm{pCi} / \mathrm{ml}\right.$ ) within Aquifer Zone $\mathrm{IB}_{2}$ (Water Table) for injection wells injecting $10,000 \mathrm{pCi} / \mathrm{ml}$ over 30 years..

6.14 Simulated tritium concentration (pCi/mi) within Aquifer Zone $\mathrm{IIB}_{1}$ (Barnwell/McBean) for the injection wells injecting $10,000 \mathrm{pCi} / \mathrm{ml}$ over 30 years.

A1.1 Simulated hydraulic head distribution for Aquifer Zone $\mathbf{I B}_{2}$ (Water Table) from the regional and local models...

A1.2 Simulated hydraulic head distribution for Aquifer Zone IIB $_{1}$ (Barnwell/McBean) from the regional and local models.

A2.1 Simulated hydraulic head distribution for Aquifer Zone $\mathrm{IB}_{2}$ (Water Table) from entire regional model..

A2.2 Simulated hydraulic head distribution for Aquifer Zone $\mathbb{I B B}_{1}$ (Barnwell/McBean) from entire regional model.

A2.3 Simulated hydraulic head distribution for Aquifer Unit IIA (Congaree) from entire regional model ........................................................................................................ 104

A2.4 Areal distribution of hydraulic head residuals for Aquifer Zone IIB $_{2}$ (Water Table) for entire model area.

A2.5 Areal distribution of hydraulic head residuals for Aquifer Zone $\mathbf{I B}_{1}$ (Barnwell/McBean) for entire model area

A2.6 Areal distribution of hydraulic head residuals for Aquifer Unit IIA (Congaree) for entire model area.

A2.7 Histogram of hydraulic head residuals in Aquifer Zone $\mathrm{IB}_{2}$ (Water Table) from entire model area..

A2.8 Histogram of hydraulic head residuals in Aquifer Zone IIB 1 (Barriwell/McBean) from entire model area.

A2.9 Histogram of hydraulic head residuals in Aquifer Unit IIA (Congaree) from entire model area..

A2.10 Comparison of simulated to observed hydraulic heads ( $\mathrm{ft}$ ) in Aquifer Zone $\mathrm{IIB}_{2}$ (Water Table) from the entire model area.

A2.11 Comparison of simulated to observed hydraulic heads ( $\mathrm{ft}$ ) in Aquifer Zone II $_{1}$ (Barnwell/McBean) from the entire model area.. 


\section{LIST OF FIGURES (Continued)}

A2.12 Comparison of simulated to observed hydraulic heads ( $\mathrm{ft}$ ) in Aquifer

Unit IIA (Congaree) from the entire model area.

A3.1 Simulated tritium concentrations $(\mathrm{pCi} / \mathrm{ml})$ within Aquifer Zone $\mathrm{IBB}_{2}$ (Water Table) for 1991 .

A3.2 Simulated tritium concentrations ( $\mathrm{pCi} / \mathrm{ml})$ within Aquifer $\mathrm{Zone} \mathrm{IIB}_{1}$ (Barnwell/McBean) for 1991.

A3.3 Simulated tritium concentrations ( $\mathrm{pCi} / \mathrm{ml}$ ) within Aquifer Zone $\mathrm{IB}_{2}$ (Water Table) for 1988

A3.4 Simulated tritium concentrations (pCi/ml) within Aquifer Zone $\mathrm{IB}_{1}$ (Barnwell/McBean) for 1988.

A3.5 Simulated tritium concentrations (pCi/ml) within Aquifer Zone $\mathrm{IB}_{2}$ (Water Table) for 1986

A3.6 Simulated tritium concentrations ( $\mathrm{pCi} / \mathrm{ml})$ within Aquifer $\mathrm{Zone} \mathrm{IB}_{1}$ (Barnwell/McBean) for 1986

A3.7 Simulated tritium concentrations ( $\mathrm{pCi} / \mathrm{ml}$ ) within Aquifer Zone $\mathrm{IB}_{2}$ (Water Table) for 1978

A3.8 Simulated tritium concentrations $(\mathrm{pCi} / \mathrm{ml})$ within Aquifer $\mathrm{Zone} \mathrm{IIB}_{1}$ (Barnwell/McBean) for 1978..

A3.9 Simulated tritium concentrations ( $\mathrm{pCi} / \mathrm{ml}$ ) within Aquifer Zone $\mathrm{IB}_{2}$ (Water Table) for 1970

A3.10 Simulated tritium concentrations ( $\mathrm{pCi} / \mathrm{ml}$ ) within Aquifer Zone $\mathrm{IB}_{1}$ (Barnwell/McBean) for 1970 . 


\section{LIST OF TABLES}

1.1 Hydraulic Conductivity Values from Multiple Well Aquifer Tests within the vicinity of the F- and H-Area Seepage Basins.

2.1 Hydrostratigraphic unit represented by each model layer. ................................................. 13

4.1 Model parameters used for flow model calibration. The parameters are for regional model columns 1 through 30 .

- 4.2 Model elevations of Fourmile Creek bed and top of Confining Zone $\mathrm{IBB}_{1}-\mathrm{IIB}_{2}$ (Tan Clay) and the difference between them in feet

4.3a Residual values for observation wells within modified model area (F-Area Seepage Basins)

4.3b Residual values for observation wells outside modified area.. .........................................43

4.4a Residual head statistics for the modified area and layers. ...........................................58

4.4b Residual head statistics for the entire model area......................................................58

5.1 Transport parameters used for transport model simulations. The parameters were used for the entire model...........................................................................................66

6.1 F-Area Seepage Basins remediation well locations, flow rates, and drawdowns............. 84 


\section{EXECUTIVE SUMMARY}

The objective of the groundwater modeling effort described in this report is to develop a remediation well network capable of containing and controlling specified groundwater plumes near the F-Area Seepage Basins, Savannah River Site. The specified plumes are the 10,000 $\mathrm{pCi} / \mathrm{ml}$ tritium plumes defined in the RCRA Hazardous Waste Part B Permit for the F-Area Basins (WSRC, 1992a). The remediation system consists of a total of 18 wells with an estimated total flow rate of 165 gallons per minute. The well network within Aquifer Zone $\mathrm{IIB}_{2}$ (Water Table) consists of 7 extraction wells and 7 injection wells with a simulated pumping rate of 139 gallons per minute. The well network within Aquifer Zone $\mathrm{IBB}_{1}$ (Barnwell/McBean) consists of 2 extraction wells and 2 injection wells with a simulated pumping rate of 26 gallons per minute. Remediation well locations are specified which not only capture the required plumes using the model calibrated parameters, but also will conceptually have the ability to capture the required plumes under a variety of hydraulic parameter distributions. Well pumping and injection rates are based on rates and well efficiencies seen during field testing; however, the flow rates are approximate and will need to be adjusted to compensate for field versus model conditions.

The remediation well network was simulated in both a regional model of the General Separations Area (GSA) and a local model of the area near the F- and H-Area Seepage Basins. The regional model was calibrated to measured hydraulic head values, particle traces of advective flow and water gain along Fourmile Branch. The local model was dependent on the regional model for boundary conditions. Tritium transport was simulated within the local model from 1955 through 1992 and compared to measured tritium concentrations near the F-Area Seepage Basins.

The current modeling effort is built upon a previous modeling effort of the GSA and the F- and H-Area Seepage Basins areas documented in GeoTrans (1993). Because the area near the F-Area Seepage Basins is the main focus for current effort, model parameters were modified for only the western third of the GeoTrans (1993) model. The model calibration process and scenarios simulated are based on the GeoTrans (1993) model. 


\section{ACKNOWLEDGMENTS}

\section{Todd Ross}

* Wrote computer programs to access FTWORK output files to create MODPATH input files.

* Set up and ran MODPATH program for the local flow model and well network scenarios.

* Debugged MODPATH input files that were being read incorrectly.

* Created computer programs that read MODPATH output files and created input files with the proper format to be used in TECPLOT.

* Used TECPLOT to create plots that contained particle paths generated by MODPATH

* Both plan view and cross-sections of particle paths were created in TECPLOT.

* TECPLOT and MODPATH output files used to determine the percent of capture with the final well network scenario.

* Set up and ran EARTHVISON software with MODPATH output to create 3-D models of the particle paths.

* Set up and ran QUICKFLOW analytical groundwater flow modeling program to help check well network scenarios.

Larry Hamm

* Set up the FTWORK package (FTWORK, SLICER, TECPLOT) and maintained it in a code configuration management system.

* Upgraded FTWORK to create graphics output data.

* Developed SLICER to probe the graphics output data and generate TECPLOT-ready graphics files.

* Setup of TECPLOT and UNIX environmental variables necessary for operation.

* Tested the overall package and certified that package was adequate for use.

* Created the General Separations Area basemaps (roads, buildings, streams, and seepage lines) for use within TECPLOT.

Dan Boltz

* Wrote FORTRAN program RTOL which uses linear interpolation to calculate hydraulic head values for the local model from the hydraulic head values of the regional model. In addition to calculating the local model hydraulic head values, this program flags local nodes that are dry cells or are no-flow boundaries. The output file from this program is used as input to FTWORK.

* Computer support: worked with local network system administrators to facilitate use of applications and graphics software and hardcopy output devices. 


\section{Larry Koffman}

* Debugged the FTWORK code version being used to correctly format output to be used with MODPATH, and documented the changes to the source code.

* Set up the FTMOD17 program from Geo'Trans to automate generation of MODPATH input files from the FTWORK output; use of FTMOD17 and MODPATH was documented as a procedure.

* Provided computer programs to generate particle tracking input locations for MODPATH.

* Debugged a MODPATH input file that was being read incorrectly and corrected the read format in the file.

* Assisted with TECPLOT usage and helped set up and maintain computing and printing capabilities.

Chris Langevin

* Wrote and tested ARC/INFO program to overlay regional and local model grid. The program was used to aid in the transferring of data from the regional to the local model. 


\subsection{INTRODUCTION}

\subsection{Background}

On September 30, 1992, the South Carolina Department of Health and Environmental Control (SCDHEC) issued a Resource Conservation and Recovery Act (RCRA) Hazardous Waste Part B Permit prescribing remediation of contaminated groundwater beneath and downgradient of the Fand $\mathrm{H}$-Area Seepage Basins at the Savannah River Site (Figure 1.1). The remediation outlined in the Part B Permit calls for a three phase approach. For the F-Area Seepage Basins, the first phase requires the "installation of an adequate number of pumping and injection wells or trenches, as appropriate, to capture and remediate those portions of the contaminant plume delineated by the $10,000 \mathrm{pCi} / \mathrm{ml}$ tritium isoconcentration contour." Geochemical results from 1992 groundwater monitoring were used to delineate this isoconcentration contour in the Corrective Action Program (CAP) (WSRC, 1992a). The 1992 results were used based on SCDHEC written requirement to use the most recent data available at the time the CAP was formulated. The rationale used by SCDHEC in selecting the $10,000 \mathrm{pCi} / \mathrm{ml}$ tritium isoconcentration contour was that it also encompassed most of the other contaminants listed in the Groundwater Protection Standards. After extraction and treatment, the water is required to be reinjected into the aquifer due to the high levels of tritium still present in the treated water. The conceptual plan is to have recirculation of the tritium (as much as can practically be accomplished) to allow more time for radioactive decay before natural discharge to surface water.

\subsection{Objective and Approach}

- The objective of this modeling effort was to develop a remediation well network capable of containing and controlling the plumes as required by SCDHEC near the F-Area Seepage Basins. The network was developed using a three-dimensional groundwater flow and transport model calibrated to measured field data. The specified remediation well locations would not only capture the required plumes as simulated by the model, but also would conceptually have the ability to capture the required plumes under a variety of hydraulic parameter distributions. Well pumping and injection rates within the model are based on rates and well efficiencies observed during field testing.

This modeling effort is built upon a previous modeling effort simulating the General Separations Area (GSA) and the F- and H-Area Seepage Basins areas documented in GeoTrans (1993). The present modeling effort was initiated due to several technical uncertainties present in the GeoTrans (1993) model (Schappell and Sadler, 1993), and the availability of recent aquifer testing results. The approach for this present modeling effort consisted of starting with the GeoTrans (1993) model, modifying the parameters near the F-Area Seepage Basins to simulate a simplified hydrogeologic system utilizing recent aquifer test data, and calibrating the model to the same measured heads used in GeoTrans (1993). Because of this approach, many model attributes reported in GeoTrans (1993) are the same for this modeling effort. Description of the similar attributes will be repeated in this report only briefly. Description of model differences will addressed in more detail. 


\subsection{Hydrogeology}

\subsubsection{General}

The hydrostratigraphic unit nomenclature used in this report is presented in Figure 1.2. A general description of the hydrogeologic setting is given in GeoTrans (1993) and WSRC (1992a). The hydraulic head distributions near the F-Area Seepage Basins from the second quarter of 1991 are shown in Figures 1.3 through 1.5 for each aquifer zone.

\subsubsection{Estimate of Hydraulic Conductivity}

Within the past two years, six aquifer tests have been performed near the F- and H-Area Seepage Basins; three within Aquifer Zone $\mathrm{IB}_{2}$ (Water Table) and three within Aquifer Zone $\mathrm{IBB}_{1}$ (Barnwell/McBean). Each of the tests utilized observation wells to provide data for analysis (multiple well tests). Before these tests, no multiple well aquifer tests had been performed within Aquifer Zone $\mathrm{IB}_{2}$ (Water Table) and only one had been performed within Aquifer Zone $\mathrm{IB}_{1}$ (Barnwell/McBean). Previous field tests for hydraulic conductivity in these aquifer zones have been either slug tests or single well pumping tests. A summary of the multiple well tests are presented in Table 1.1. Location of test wells and observation wells are shown in Figures 1.6 and 1.7:

The hydraulic conductivity values estimated from the three multiple well aquifer tests in Aquifer Zone $\mathrm{IIB}_{2}$ (Water Table) are much higher than the values estimated from slug and single well testing. Most of the slug and single well tests were performed on water quality monitoring wells which were drilled with the mud rotary technique and on which well development was limited to physical means; no chemical additive was used to help breakup the mud cake on the wall of the borehole. Well development was not a priority because the wells were planned to be used for water quality monitoring only. This practice produces hydraulically inefficient wells. The problem with slug tests and single well pumping tests is that they depend only upon the water level in the stressed well, not in observation wells. When an inefficient well is stressed, changes in the well are much different than in the aquifer just outside the borehole. Therefore, there is a possibility that the hydraulic conductivity values from slug and single well pumping tests in the vicinity of the F- and H-Area Seepage Basins are systematically low due to the effects of clay on the borehole walls. Some single well tests in the area have been analyzed accounting for well inefficiency. However, these analyses used well efficiency values of around 90 percent, when well efficiencies are probably much lower.

The hydraulic conductivity values used in this modeling effort are based on the multiple well aquifer testing listed above. Analytical results from slug and single well aquifer testing were not used. 


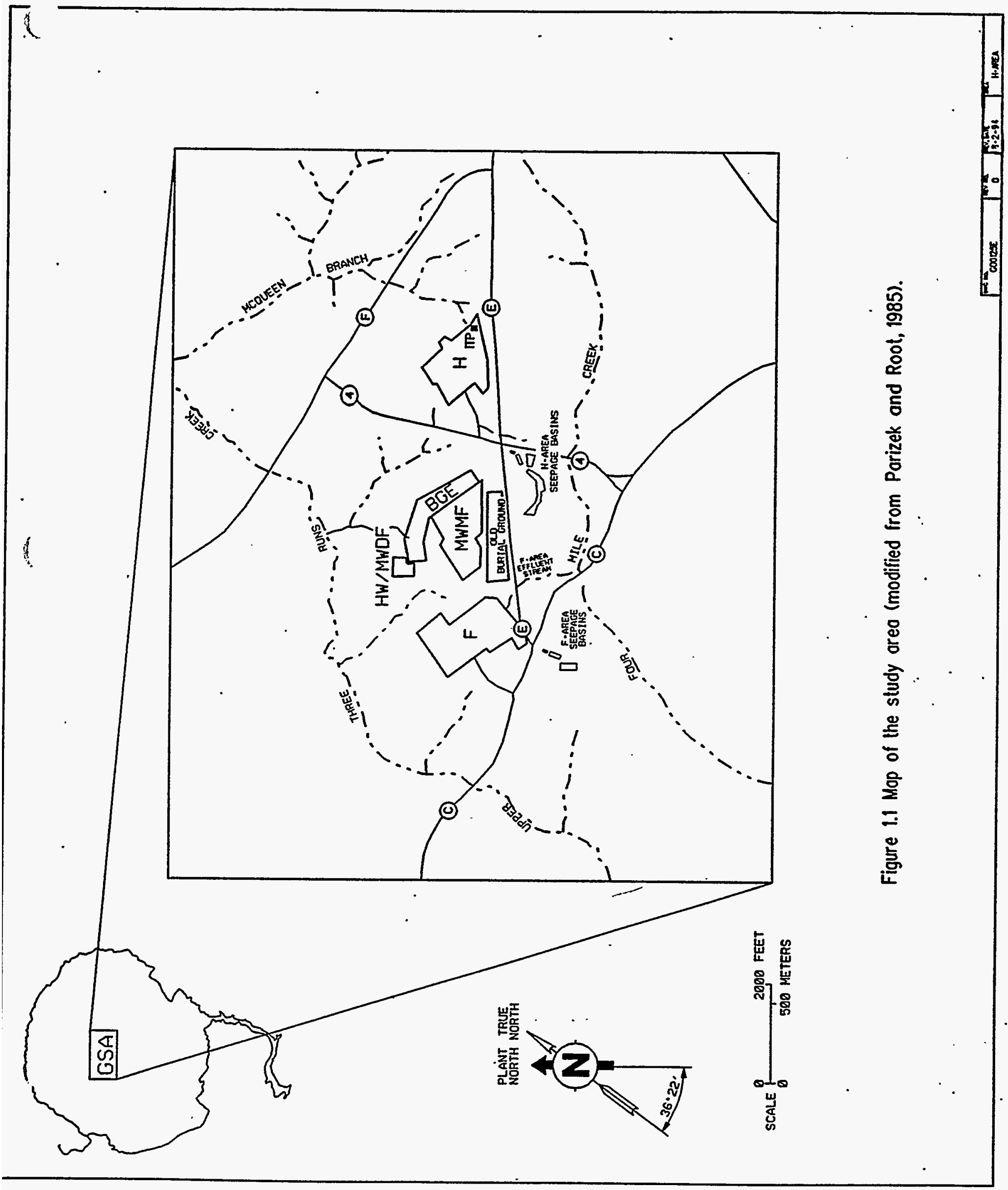




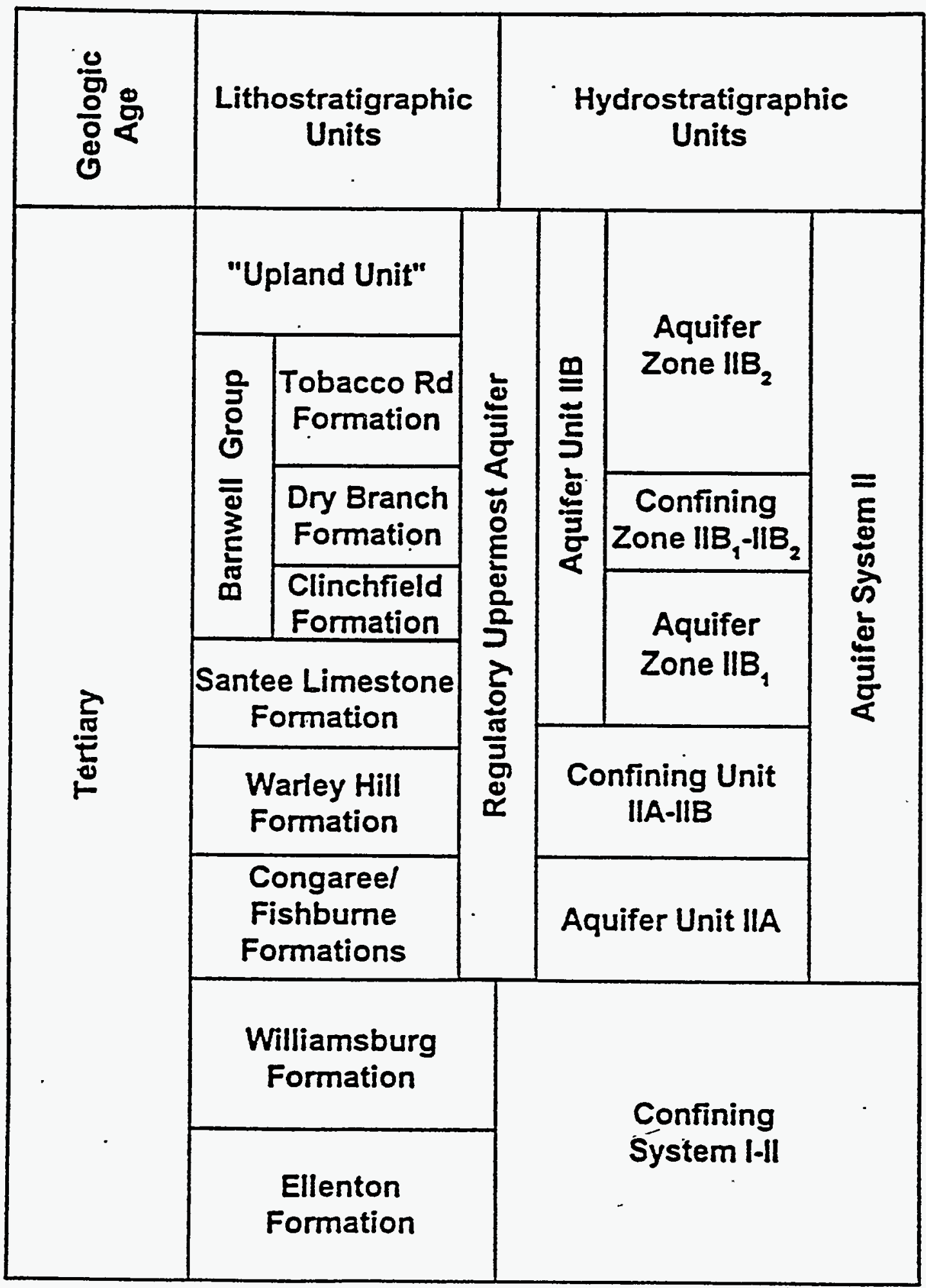

Aadland, 1990

Figure 1.2. Hydrostratigraphic nomenclature used from Aadland, 1990. 


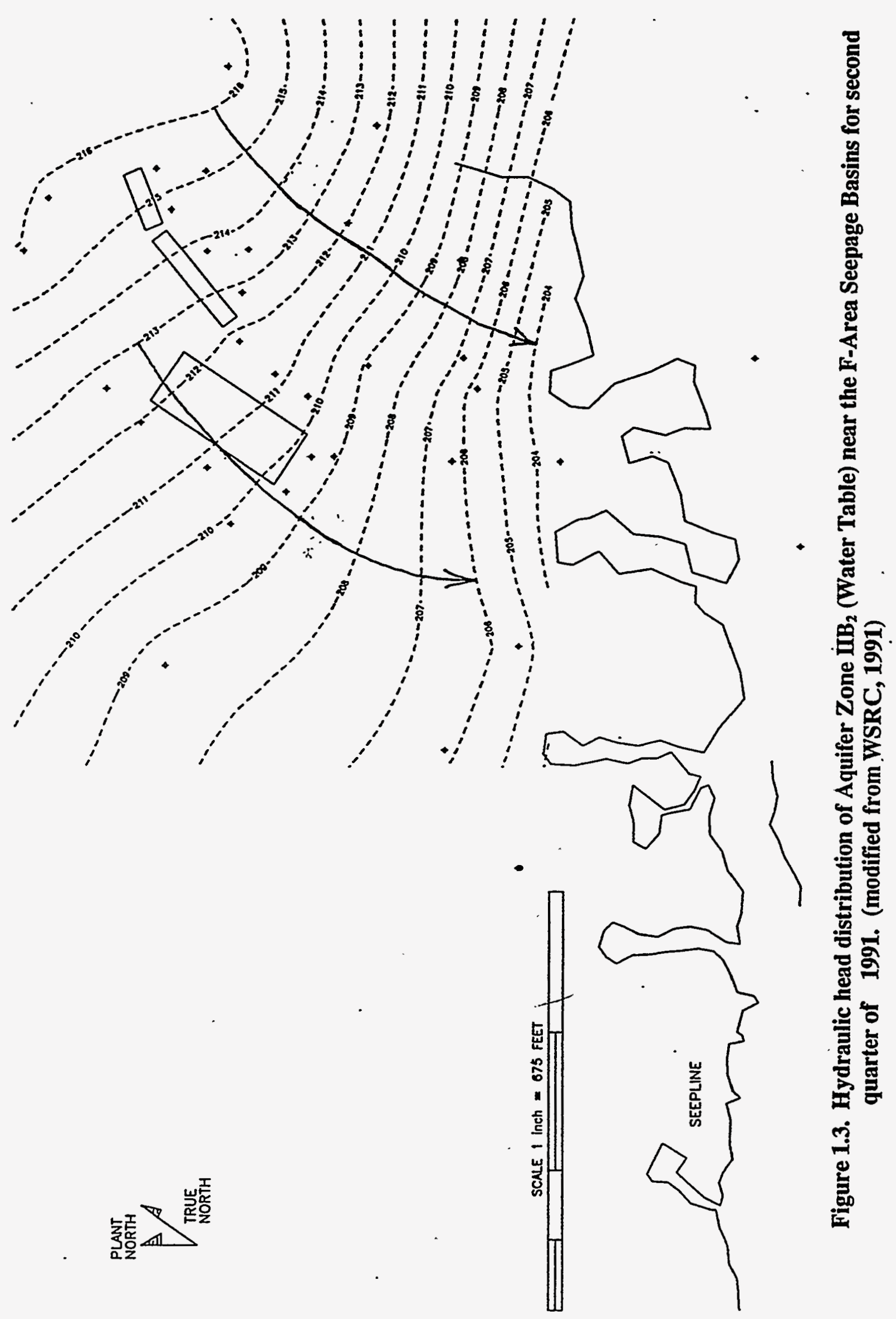




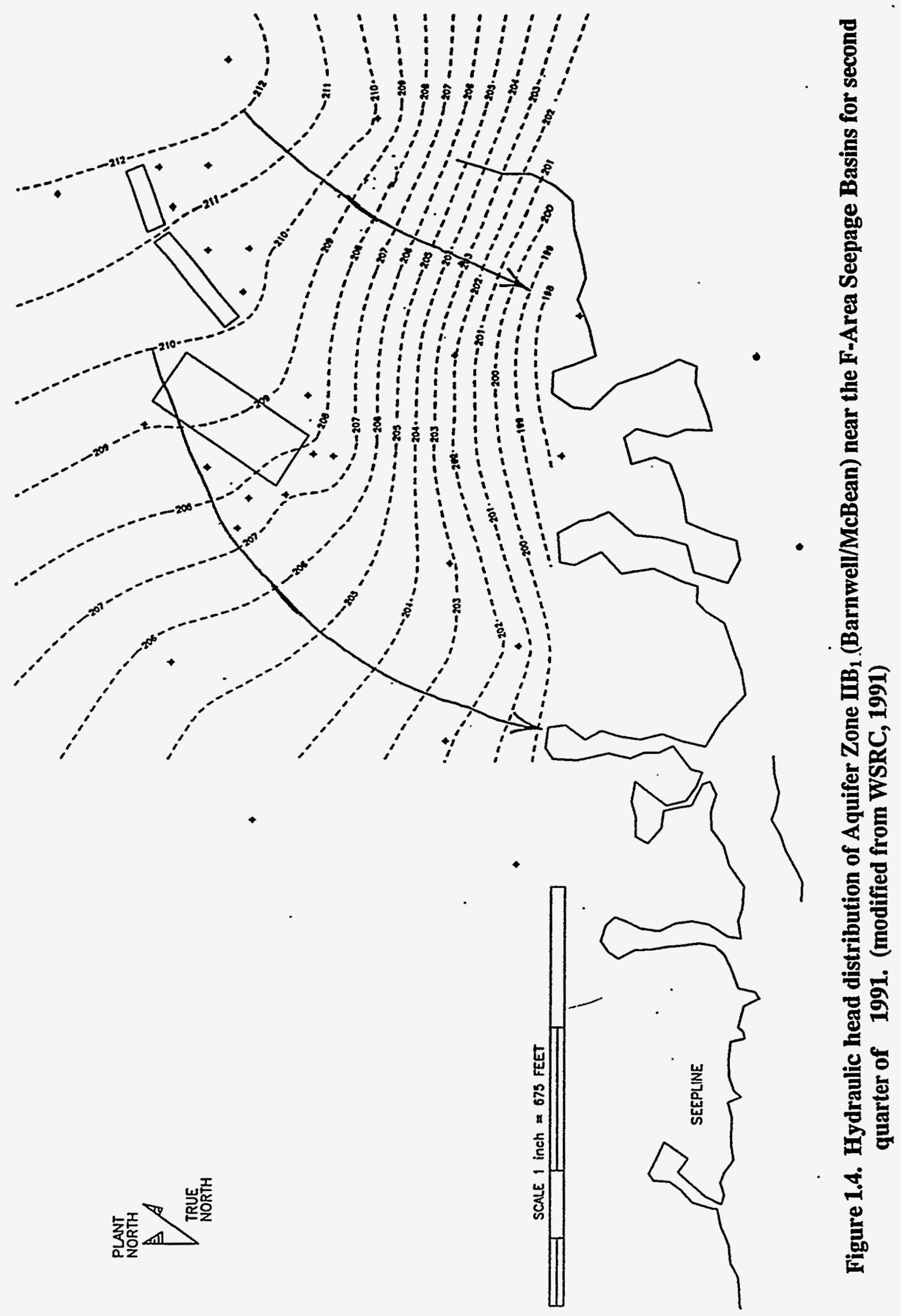




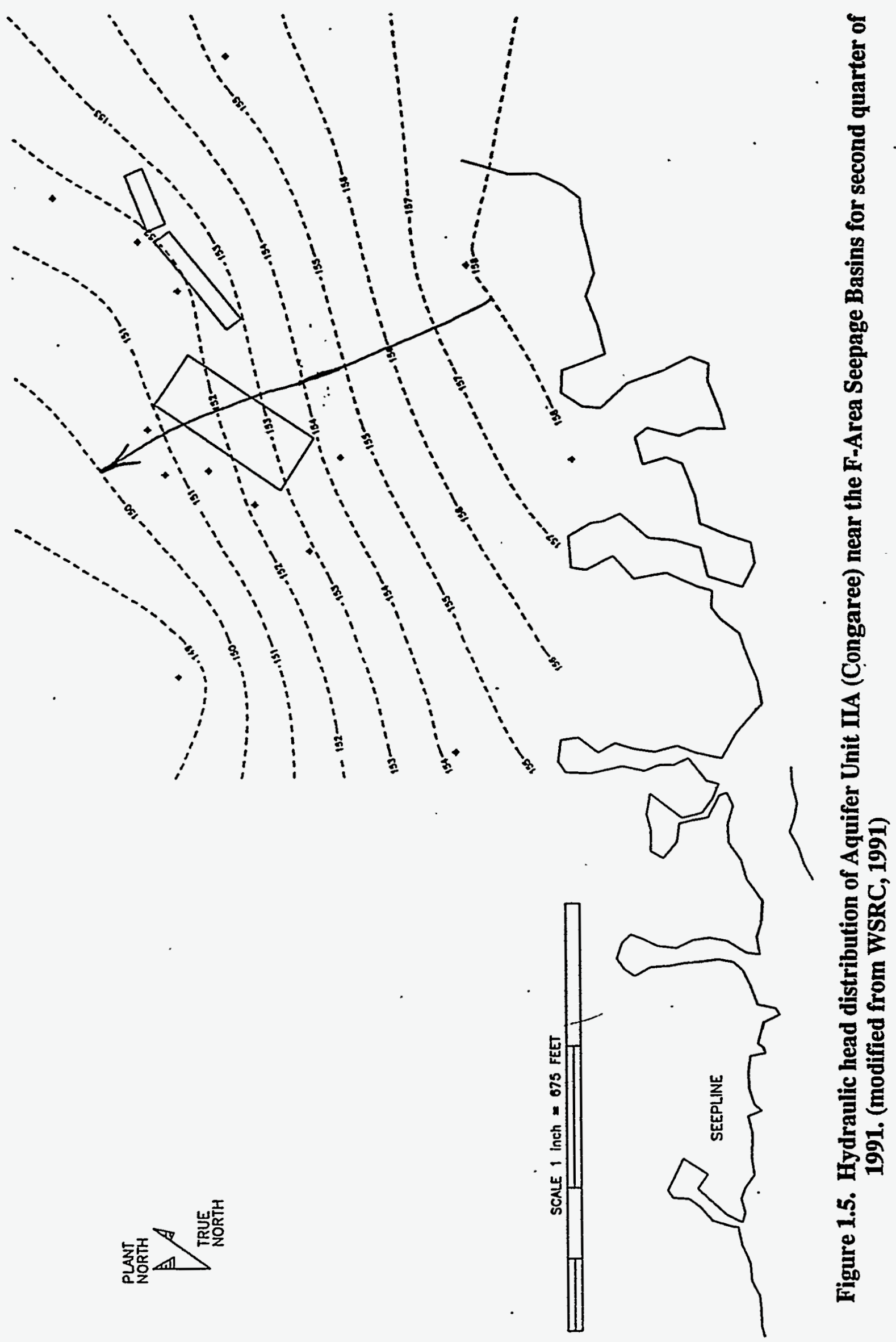


Table 1.1. Hydraulic Conductivity Values from Multiple Well Aquifer Tests within the vicinity of the F- and H-Area Seepage Basins.

\begin{tabular}{|l|l|c|l|}
\hline Test Well & \multicolumn{1}{|c|}{ Aquifer Zone } & $\begin{array}{l}\text { Approximate Horizontal } \\
\text { Hydraulic Conductivity }\end{array}$ & Reference \\
\hline FIW-1ID & $\mathrm{IIB}_{2}$ (Water Table) & $40 \mathrm{ft} /$ day & Sadler (1993) \\
\hline FSB-OPD & $\mathrm{IBB}_{2}$ (Water Table) & $42 \mathrm{ft} /$ day & Day (1995a) \\
\hline HIW-1ID & $\mathrm{IB}_{2}$ (Water Table) & $20 \mathrm{ft} /$ day & Sadler (1993) \\
\hline FIW-2IC & $\mathrm{IB}_{1}$ (Barnwell/McBean) & $8 \mathrm{ft} /$ day & Sadler (1993) \\
\hline FSB-OPC & $\mathrm{IB}_{1}$ (Barnwell/McBean) & $2 \mathrm{ft} /$ day & Swift (1994) \\
\hline FSB-88C & $\mathrm{IB}_{1}$ (Barnwell/McBean) & $8 \mathrm{ft} /$ day & C.T. Main (1990) \\
\hline HIW-2IC & $\mathrm{IB}_{1}$ (Barnwell/McBean) & $4 \mathrm{ft} /$ day & Day (1995b) \\
\hline
\end{tabular}




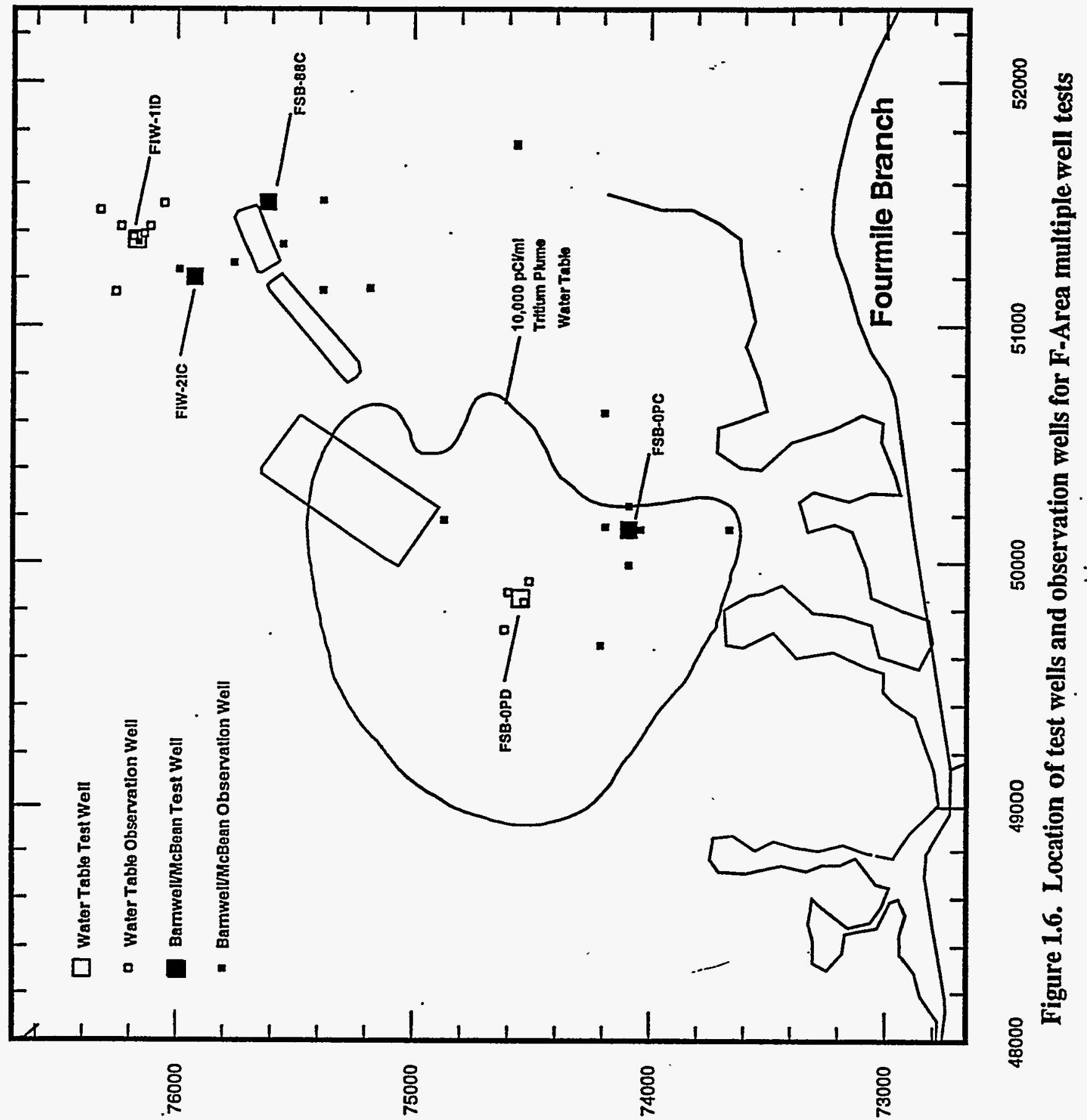




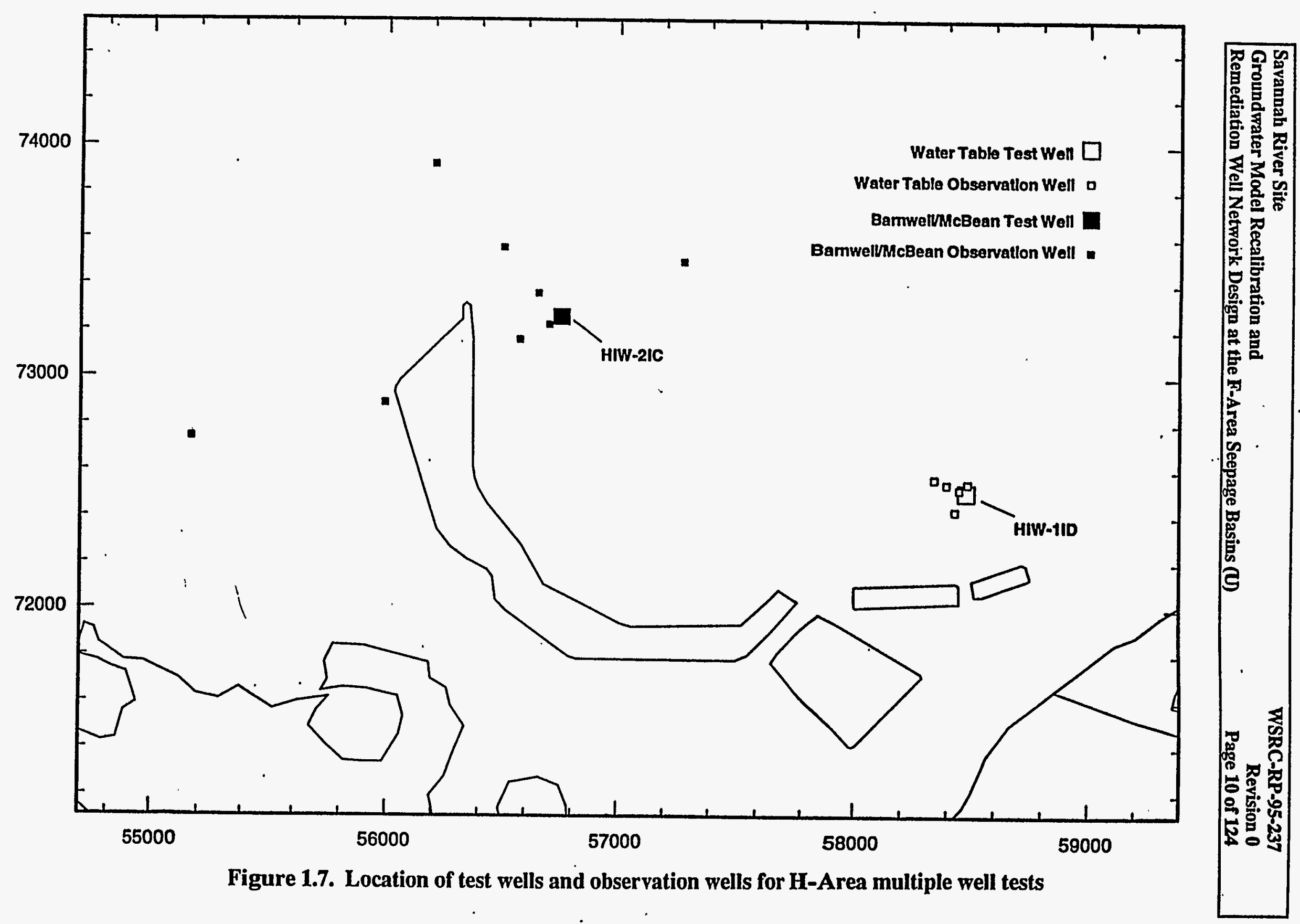




\subsection{MODEL STRUCTURE}

\section{.2 .1 Overview}

The model structure of GeoTrans (1993) was the base for the present modeling effort. Modifications to this structure were minimal. The model structure includes model grid origin, orientation, horizontal discretization, vertical discretization; stratigraphic delineation; boundary conditions; seepage basin recharge and concentration input; and calibration targets. The limited differences between the two model structures are in layer thickness in two areas, stream boundary conditions along a section of Fourmile Branch, and the omission of monitoring wells suspected of crossing confining zones as calibration targets. Details of these modifications are given in Sections 4.2.6, 4.2.3, and 4.3.1, respectively. As with the GeoTrans (1993) methodology, two models were actually used in this effort; a regional model of the General Separations Area and a local model of the F- and H-Area Seepage Basins. The coarser gridded regional model was used to supply boundary conditions for the finer gridded local model.

\subsection{Horizontal Discretization}

The horizontal grid discretization, in both the regional and local model, is the same as in GeoTrans (1993).

The finite difference areal grid for the regional model contains 91 columns and 75 rows. The lower left corner of the grid is located at SRS coordinates E42500 N69500. The grid is oriented at an angle of 13.285 degrees, clockwise, relative to SRS coordinates. Most of the modeled area is covered by the minimum grid spacing of 200 feet by 200 feet. The maximum grid spacing is 1,246 feet at the edge of the model area. The ratio between adjacent grid spacings is less than 1.2 .

The areal grid for the local model contains 202 columns and 91 rows. The lower left comer of the local grid is located at E46354 N73499 and the grid is oriented at an angle of 28.902 degrees, clockwise relative to SRS coordinates. The local grid is totally encompassed by the regional grid (Figure 2.1). The smallest grid spacing of 45 feet covers most of the area of concern, while the largest spacing, outside the area of most concern, is 300 feet. The ratio between adjacent grid spacings is less than 1.2.

\subsection{Vertical Discretization}

The vertical discretization in the current modeling effort is the same as in GeoTrans (1993) except for changes to layer thicknesses in two areas; details of these differences are given in Section 4.2.6.

The regional model contains five layers while the local model contains three layers (Table 2.1). The local model uses a general head boundary to simulate vertical flow across Confining Unit IIA-IIB (Green Clay) into Aquifer Unit IIA. (Congaree). 


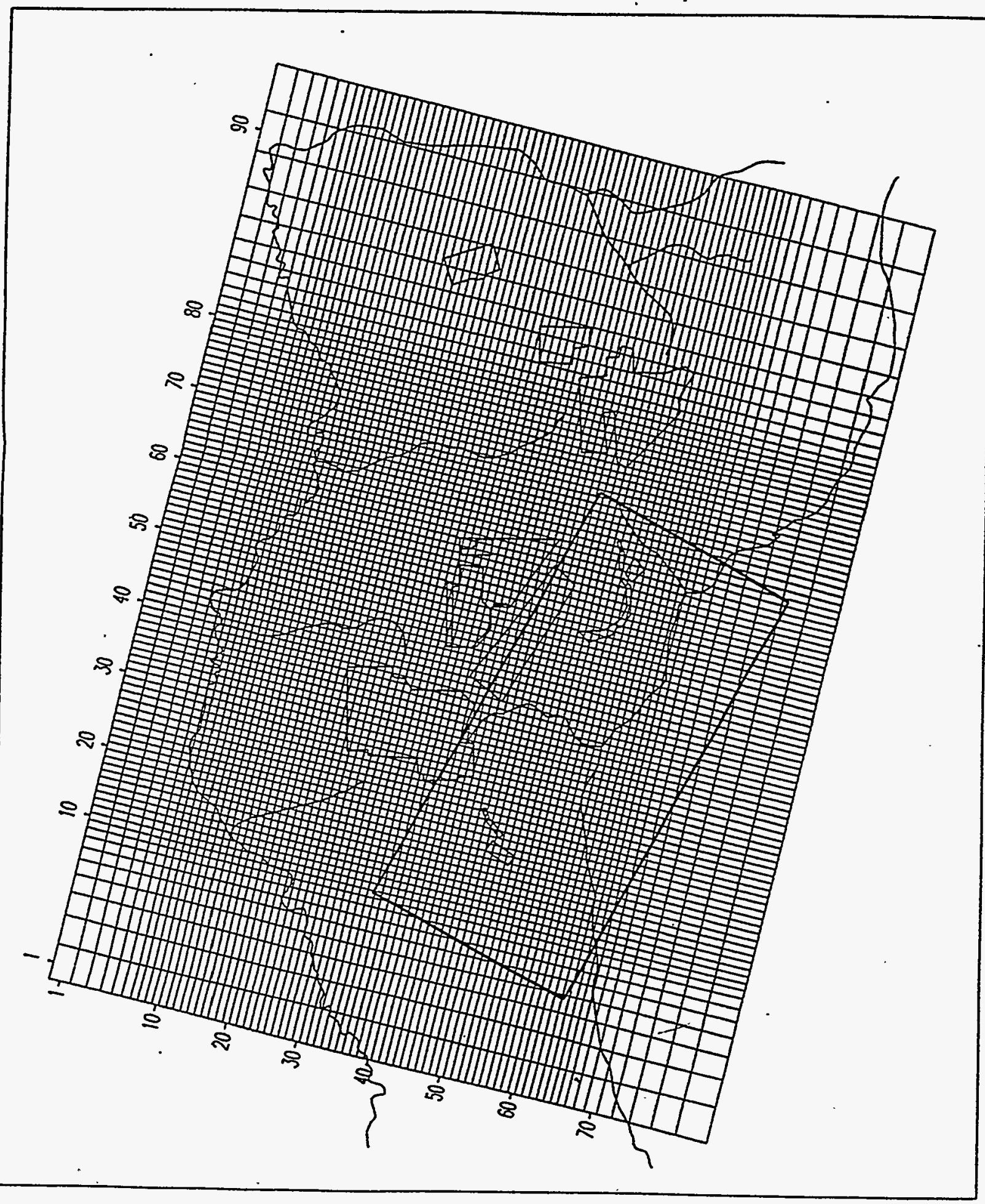

엉 
Table 2.1. Hydrostratigraphic unit represented by each model layer.

\begin{tabular}{|c|c|c|}
\hline $\begin{array}{c}\text { HYDROSTRATIGRAPHIC } \\
\text { UNIT }\end{array}$ & $\begin{array}{c}\text { REGIONAL } \\
\text { MODEL }\end{array}$ & $\begin{array}{c}\text { LOCAL } \\
\text { MODEL }\end{array}$ \\
\hline Aquifer Zone $\mathrm{IBB}_{2}$ (Water Table) & Layer 1 & Layer 1 \\
\hline Confining Zone $\mathrm{IB}_{1}-$ IIB $_{2}$ (Tan Clay) & Layer 2 & Layer 2 \\
\hline Aquifer Zone IIB (Barnwell/McBean) & Layer 3 & Layer 3 \\
\hline Confining Unit IIA-IIB (Green Clay) & Layer 4 & General Head Boundary in Layer 3 \\
\hline Aquifer Unit IIA (Congaree) & Layer 5 & General Head Boundary in Layer 3 \\
\hline
\end{tabular}

Model layer thicknesses and top elevations were estimated using stratigraphic data input into the Geographic Information System (GIS) software package ARC/INFO. The data sources and techniques used to generate these layers and the resulting stratigraphic surfaces/thicknesses are given in GeoTrans (1993).

\subsection{Boundary Conditions}

\subsubsection{Overview}

The boundary condition assignments in the current modeling effort are the same as in GeoTrans (1993) except for the stream boundary conditions along a section of Fourmile Branch. Though boundary condition assignments are similar, the parameters and specific values of the boundary conditions changed during model calibration; details of the differences are given in Section 4.2.

\subsubsection{Regional Model}

Maps delineating boundary conditions for the models are contained in GeoTrans (1993). A summary of the boundary conditions for the regional model follows.

\section{Layer 1, Aquifer Zone $\mathbb{I B}_{2}$ (Water Table):}

South: The model area is bounded on the south by a river boundary condition which corresponds to Fourmile Branch. The area south of this boundary is inactive.

North: The model area is bounded on the north by inactive cells. This corresponds to the area in which Aquifer Zone $\mathrm{IIB}_{2}$ (Water Table) does not exist due to the downward erosion of Upper Three Runs Creek.

East and West: The eastern and western boundaries of the model area are no-flow boundaries. No-flow boundaries are used at these locations because flow should be roughly parallel to the boundaries and these boundaries are adequately distanced from the area of interest.

Top: Layer 1 is treated as an unconfined aquifer. Input of recharge from precipitation and from basin discharge occurs through the top of this layer. 
Other: River boundaries are also used for the F-Area Effluent Stream, the H-Area Effluent Stream, and the upper part of McQueen Branch.

Drain boundaries are used to represent wetlands near Fourmile Branch, the northern boundary near Upper Three Runs Creek, and intermittent parts of the F-Area Effluent Stream, H-Area Effluent Stream, and the upper part of McQueen Branch.

Layer 2, Confining Zone IIB $_{1}-$ IIB $_{2}$ (Tan Clay)

South: A few cells have river boundary conditions along Fourmile Branch. All cells have no-flow conditions toward the south.

North, East, and West: No-flow conditions are assigned along the north, east, and west boundaries (inactive cells or implicit no-flow).

Other: No other type of boundaries exist in this layer.

Layer 3. Aquifer Zone IIB 1 (Barnwell/McBean):

South: The model area is bounded on the south by inactive or implicit no-flow boundaries.

North: The model area is bounded on the north by inactive cells. This corresponds to the area in which Aquifer Zone $\mathrm{IIB}_{1}$ (Barnwell/McBean) does not exist due to the downward erosion of Upper Three Runs Creek.

East and West: The eastern and western boundaries of the model area are no-flow boundaries. No-flow boundaries are used at these locations because flow should be roughly parallel to the boundaries and these boundaries are adequately distanced from the area of interest. Part of the eastern boundary also contains river boundary conditions corresponding to the midsection of McQueen Branch.

Other: River boundaries are also used for Crouch Branch and an unnamed tributary to Upper Three Runs Creek.

Drain boundaries are placed along Upper Three Runs Creek where Aquifer Zone IIB $_{1}$ (Barnwell/McBean) outcrops to land surface.

Layer 4, Confining Unit IIA-IIB (Green Clay):

All Boundaries: All boundaries for this unit are no-flow boundaries.

Other: No other type of boundaries exist in this layer.

Layer 5, Aquifer Unit IIA (Congaree):

North: The model area is bounded on the north by a river boundary condition which corresponds to Upper Three Runs Creek and McQueen Branch. The area north of this boundary is inactive.

South, East, and West: The model area is bounded on the south, east, and west by constant (specified) head boundaries.

Bottom: The bottom of Aquifer Unit IIA (Congaree) is treated as a no flow boundary.

Other: Drain boundaries are placed along Upper Three Runs Creek where Aquifer Unit IIA (Congaree) outcrops to land surface.

\subsubsection{Local Model}

The boundary conditions assigned in the local model are the same as for the regional model (for the area which the local model represents). There is greater resolution in the local model due to 
finer grid spacing. Because the local model represents only a portion of the regional model, the northern, western, and eastern boundaries of all aquifer layers in the local model are assigned constant (specified) head boundaries. The hydraulic head values used as the constant head boundaries are interpolated from the regional model for each specific model scenario simulated. No-flow boundaries surround Confining Zone $\mathrm{IBB}_{1}-\mathrm{IIB}_{2}$ (Tan Clay). The local model has only three explicit layers. Confining Unit IIA-IIB (Green Clay) and Aquifer Unit IIA (Congaree) are represented in the local model using a general head boundary. This configuration is also true for the model reported in GeoTrans (1993), though not explicitly stated in that report.

Layer 1, Aquifer Zone $\mathrm{IBB}_{2}$ (Water Table):

South: The model area is bounded on the south by a river boundary condition which corresponds to Fourmile Branch. The area south of this boundary is inactive.

North, East, and West: : The model area is bounded on the north, east, and west by constant (specified) head boundaries interpolated from the regional model.

Top: Layer 1 is treated as an unconfined aquifer. Input of recharge from precipitation and from basin discharge occurs through the top of this layer.

Other: River boundaries are also used for the F-Area Effluent Stream and the H-Area Effluent Stream.

Drain boundaries are used to represent wetlands near Fourmile Branch and the intermittent parts of the F-Area Effluent Stream and H-Area Effluent Stream.

Layer 2, Confining Zone $\mathrm{IB}_{1}-\mathrm{IIB}_{2}$ (Tan Clay)

South: A few cells have river boundary conditions along Fourmile Branch. All cells have no. flow conditions toward the south.

North, East, and West: No-flow conditions are assigned along the north, east, and west boundaries.

Other: No other type of boundaries exist in this layer.

Layer 3. Aquifer Zone $\Pi_{1}$, (Barnwell/McBean):

South: The model area is bounded on the south by inactive or implicit no-flow boundaries.

North, East, and West: : The model area is bounded on the north, east, and west by constant (specified) head boundaries interpolated from the regional model.

Bottom: A general head boundary is applied to the bottom of Layer 3, Aquifer Zone $\mathrm{IIB}_{1}$ (Barnwell/McBean). A general head boundary creates a head dependent flux. The flux across the boundary is dependent on the difference between: a constant, given head value, a simulated head value, and the hydraulic conductivity and thickness of the material separating the two head values. For the current application, the constant, given head values represent head values in Aquifer Unit IIA (Congaree) as interpolated from the regional model. The simulated head values are from Layer 3, Aquifer Zone IIB $_{1}$ (Barnwell/McBean) of the local model. The hydraulic conductivity and thickness of the material is representative of Confining Unit IIA-IIB (Green Clay) used in the regional model. Use of the general head boundary at the bottom of Layer 3 provides a realistic type boundary, however with this configuration, the tritium concentrations for Layer 5 , Aquifer Unit IIA (Congaree) can not be directly simulated. 


\subsection{Model Code and Version}

The code FTWORK was used for the current modeling effort. This code was chosen because it was used for the modeling effort in GeoTrans (1993). FTWORK was developed by GeoTrans, Inc. (Faust, et al., 1990) and is a finite difference model for simulation of flow and solute transport processes in fully saturated porous media in one, two, or three dimensions. Both flow and transport processes are estimated using a finite difference approximation of the respective equations. The modeling simulations presented in this report were accomplished using a slightly modified FTWORK Version 2.9CRC (Faust, et al., 1993).

FTWORK Version 2.9CRC was slightly modified to create output data for graphics. A special purpose SLICER code was written to convert the FTWORK graphics output into a form that is TECPLOT-ready. TECPLOT is a commercially available interactive graphics tool requiring no additional alterations. TECPLOT also has the capability to perform particle tracing given two or three dimensional velocity fields. The above programs represent the FTWORK package that has recently been placed under software management control under SRS procedures L18.20 (SRTC) and WSRC E7, 2.32 (Hamm, 1995).

TECPLOT was used to perform the horizontal particle tracking shown in most of the report figures. Horizontal particle tracking uses the horizontal (two-dimensional) velocity vectors, simulated within each layer, to advance the particle over time. MODPATH (Pollock, 1989) was used to perform three-dimensional particle tracking for: 1) assessment of the fate of injected water and 2) verification of the two-dimensional TECPLOT runs for the extraction/injection system control zone. MODPATH is maintained in the Software Distribution Control Center under WSRC 1Q, QAP 20-1 and WSRC E7, 2.32 specifications (Boltz and Weimer, 1994a, 1994b, 1994c). 


\subsection{MODELING APPROACH AND PROCESS}

\subsection{Modeling Approach}

The objective of this modeling effort is to develop a remediation well network to contain and control the required plumes near the F-Area Seepage Basins. This modeling effort is built upon a previous modeling effort of the General Separations Area (GSA) and the F- and H-Area Seepage Basins areas documented in GeoTrans (1993). Because the area near the F-Area Seepage Basins is the main focus for this effort, model parameters were modified for a selected section of the model presented in GeoTrans (1993). The modified area consists of columns 1 through 30 and rows 1 though 75 in the regional model (Figure 3.1). This is approximately the western third of the GeoTrans (1993) model. The area within the local model, corresponding to the modified area in the regional model, was changed to match the regional model. Column 30 of the regional model was chosen as a boundary for the modified area because it is a sufficient distance from both the F-Area Seepage Basins and the H-Area Seepage Basins so that parameter changes at this boundary have little to no effect in the areas of interest around the basins. The sections of the model near the H-Area Seepage Basins were not modified in this modeling effort. See GeoTrans (1993) for model calibration and results for these areas.

The current modeling effort for the F-Area Seepage Basins consisted of five simulation phases:

1) Calibration of the steady-state, regional General Separations Area (GSA) flow model based on 1991 groundwater monitoring conditions (50 model runs);

2) Simulation of the steady-state regional GSA flow model with operational seepage basins. Average flow inputs were used for each basin. (1 model run).

3) Simulation of the local quasi-transient flow and transient transport model (Section 5.1) in which the flow boundary conditions and parameters were input from the calibrated regional models ( 2 model runs);

4) Simulation of a remediation well network using both the regional and local steady-state flow models ( 36 model runs);

5) Simulation of the future effects of remediation well network operation on tritium spreading due to use of injection wells. Both the regional and local model with steadystate flow and transient transport conditions were used for this phase ( 3 model runs).

Because of the close association between the regional and local models, any simulated stress is simulated in the regional model. The regional model results are then used to interpolate values assigned to the constant head and general head boundaries set in the local model. A variation of this approach was used for simulation phase 3 . The results of simulation phase 2 were used to interpolate values for the constant head and general head boundaries. Therefore, average input rates to each basin were used to determine the boundary conditions and not the specific flow rate for a specific year. 


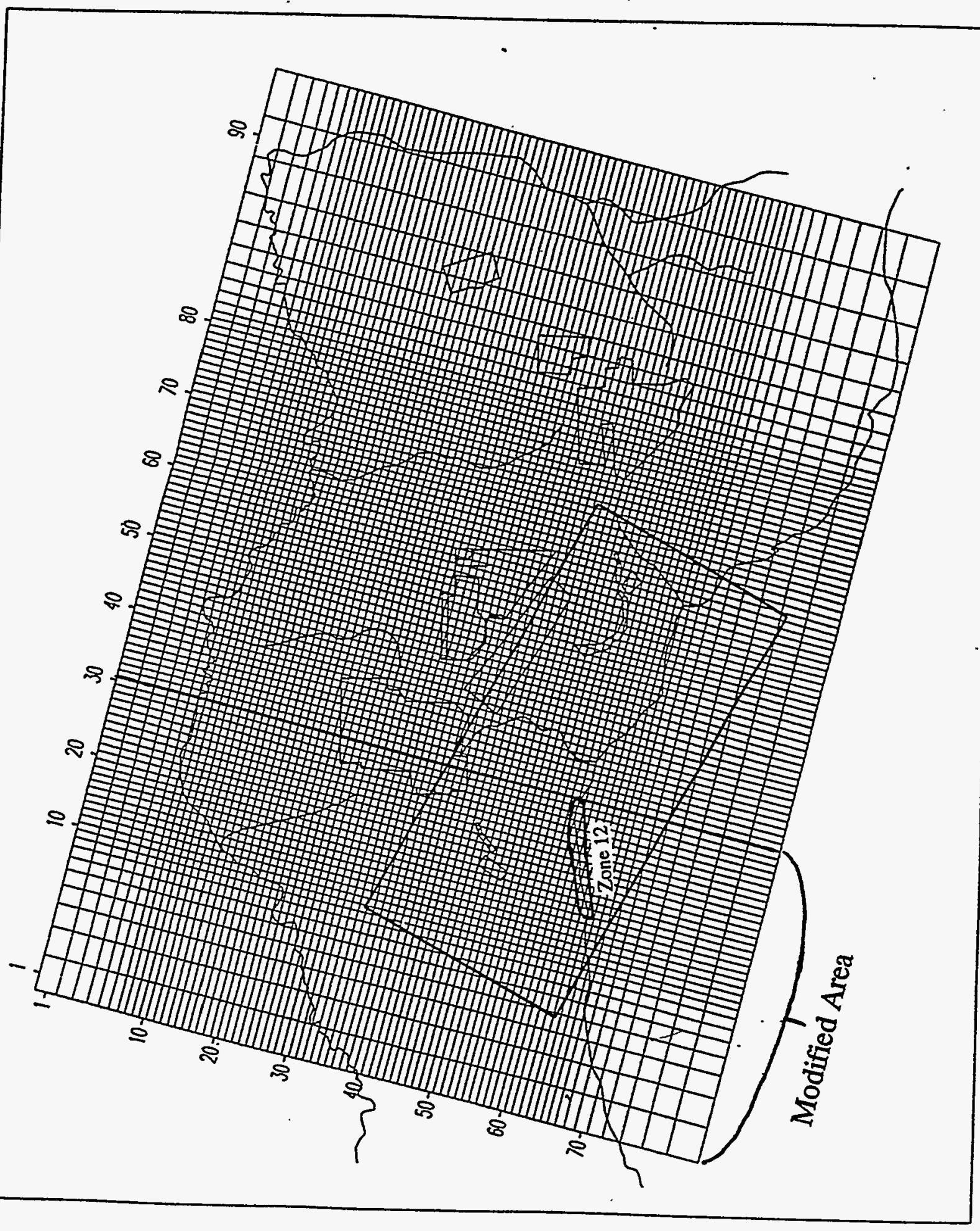




\subsection{Calibration Process}

The calibration process and targets documented in GeoTrans (1993) were used in this modeling effort except for six wells which are suspected of having sand packs constructed across confining zones (Section 4.3.1). The calibration targets used for the regional flow model were:

1) General hydraulic gradients between the groundwater divide and Fourmile Branch and vertical hydraulic gradients across the confining units;

2) Second quarter, 1991 hydraulic head elevations measured in 376 wells within the entire model area. Eighty-three of these wells are within the modified portion of the model; 55 within Aquifer Zone $\mathrm{IB}_{2}$ (Water Table) and 28 within Aquifer Zone $\mathrm{IB}_{1}$ (Barnwell/McBean);

3) General analysis of model particle tracking indicating advective trajectory of solute, approximate travel times, and number of particles entering Aquifer Unit IIA (Congaree).

4) Water gain along a section of Fourmile Branch; however, no field measurements were available for the modified portion of the model.

After the regional model was calibrated using the above targets, the calibrated parameters, boundary conditions, and interpolated regional heads were input into the local model. The simulated hydraulic head distributions of the local flow model were then compared to the simulated hydraulic head distribution of the regional model to verify they were similar (Appendix 1).

Historical transport of tritium was simulated utilizing the local flow model as a basis. Tritium transport was simulated from 1955 through 1992 using wastewater volumetric and concentration discharge data for the F-Area Seepage Basins. The values used for the wastewater input are the same as those used in GeoTrans (1993). GeoTrans (1993) presents the data on a yearly basis, explaining how the data was obtained and applied to each basin. Results of the local transport model were compared to:

1) Development and distribution of the tritium plume near the F-Area Seepage Basins from 1962 through 1992.

2) Tritium flux from the vicinity of the F-Area Seepage Basins to Fourmile Branch measured from 1967 through 1992.

3) Tritium concentrations within Aquifer Unit IIA (Congaree) near the F-Area Seepage Basins. 
Savannah River Site

Groundwater Model Recalibration and

Remediation Well Network Design at the F-Area Seepage Basins (U)

WSRC-RP-95-237

Revision 0

Page 20 of 124

\subsection{REGIONAL FLOW MODEL CALIBRATION}

\subsection{Conceptual Model}

As part of the recalibration of the regional model near the F-Area Seepage Basins, a simplified conceptual model was developed. The idea is to keep the model parameters simple and uniform until there is evidence to the contrary for a specific area. The aquifer zones near the F-Area Seepage Basins may be very heterogeneous, however, if there is no good evidence for the location and characteristics of these heterogeneities, their random inclusion in a deterministic sense can jeopardize the project goal of developing a remediation well network. With the current modeling approach, remediation well locations are specified to capture the required plumes based on model calibrated parameters, however, the design also has the capability to capture the required plumes under a variety of hydraulic conductivity distributions.

Because most groundwater models are non-unique calibrations to available data, more than one parameter can usually be altered to achieve a similar model result. The parameters altered in this modeling effort were selected based on their unlikeliness to effect the design of a remediation system. Large magnitude differences in aquifer parameters over short distances can result in large impacts on a well system design. Therefore this recalibration utilizes homogeneous, anisotropic aquifer systems. A stochastic modeling approach may be the best way to solve this problem, however, due to time constraints, this method is suggested for a future project.

The last scheduled aquifer test was performed near the F-Area Seepage Basins between the completion of model simulations and the writing of this report (Swift, 1994). This test indicates a zone of lower hydraulic conductivity in Aquifer Zone $\mathrm{IIB}_{1}$ (Barnwell/McBean). Contaminant plumes in this aquifer zone typically have two prongs, with a zone of relatively low contaminant concentrations between (Figure 4.1). The zone of relatively low contaminant concentrations may . be caused by the material in this area having a lower hydraulic conductivity than the surrounding material. The existence of a low hydraulic conductivity zone could cause most of the contaminated water thus far to flow around the zone. Because of the relative timing of this modeling and the aquifer test and because the location of the low hydraulic conductivity zone should not effect the remediation well locations, the results were not incorporated into this model. Incorporation of this zone is suggested for the future.

\subsection{Calibration Results}

\subsubsection{Overview}

The model parameters used for calibration are presented in Table 4.1. These parameters are only for model columns 1 through 30 and all rows (Figure 3.1). Zone 12 is defined as the cells which are under Fourmile Branch and which are also in columns 21 through 30. See GeoTrans (1993) for parameters near the H-Area Seepage Basins. 


\subsubsection{Hydraulic Conductivity Values}

The calibrated horizontal hydraulic conductivity values for Aquifer Zone $\mathrm{IB}_{2}$ (Water Table) and Aquifer Zone $\mathrm{IIB}_{1}$ (Barnwell/McBean) match the multiple well aquifer testing in the vicinity of the F-Area Seepage Basins (Section 1.3.1). The ratio of vertical to horizontal hydraulic conductivity $\left(\mathrm{Kv} / \mathrm{Kh}\right.$ ) values is $1 / 1000$ for Aquifer Zone $\mathrm{IIB}_{2}$ (Water Table) and 1/45 for Aquifer Zone $\mathrm{IIB}_{1}$ (Barnwell/McBean). The small ratios are considered reasonable due to the highly stratified material and the manner in which Confining Zone $\mathrm{IB}_{1}-\mathrm{IIB}_{2}$ (Tan Clay) is delineated in this modeling effort. Anderson and Woessner (1992) indicate that $\mathrm{Kv} / \mathrm{Kh}$ ratios from $1 / 1$ to $1 / 1000$ are commonly used in model applications. Further, using detailed field geologic logs describing cores from borings drilled in the modeled area and near aquifer tests (wells FIW-1MC and FIW2MA), representative hydraulic conductivity values were assigned to similar lithologies. The resultant $\mathrm{Kh}$ was near to that of the aquifer test results; the $\mathrm{Kv} / \mathrm{Kh}$ ratio ranged from $1 / 500$ to less than $1 / 1000$ for Aquifer Zone $\mathrm{IBB}_{2}$ (Water Table) and $1 / 300$ to $1 / 500$ for Aquifer Zone $\mathrm{IIB}_{1}$ (Barnwell/McBean). These ratios are for conceptual purposes only and not meant to be actual data.

The secondary reason for using $\mathrm{Kv} / \mathrm{Kh}$ values of this magnitude is to mathematically deemphasize Layer 2, Confining Zone $\mathrm{IB}_{1}-\mathrm{IB}_{2}$ (Tan Clay). The thickness of Confining Zone $\mathrm{IB}_{1}-\mathrm{IB}_{2}$ (Tan Clay) varies widely over the model; from 0 to 33 feet (see GeoTrans(1993) for data sources). Visually inspecting hydrogeologic cross sections through the area, Confining Zone $\mathrm{IIB}_{1}-\mathrm{IIB}_{2}$ (Tan Clay) may be a competent clay where the zone is delineated as being thin, and may be a mixture of sand, silt and clay in areas where the zone is delineated as being thick (WSRC, 1992a). Methods to address this variation include: $A$ ) using an average thickness and vertical hydraulic conductivity across the model; or B) lithologically evaluating each core, assigning a representative vertical hydraulic conductivity (Kv) value to the lithology, and interpreting the area over which the Kv should be applied. Because the model layers were already defined from GeoTrans (1993) and WSRC (1992a), and because method B would require more time than allotted for this modeling

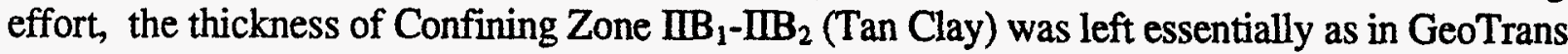
(1993) (see Section 4.2.6) and a homogeneous Kv value was applied (except for Zone 12). The low $\mathrm{Kv} / \mathrm{Kh}$ ratio for Aquifer Zone $\mathrm{IB}_{2}$ (Water Table) helps to mathematically deemphasize the thickness variations for Layer 2, Confining Zone $\Pi_{1}-\Pi B_{2}$ (Tan Clay). Therefore, if the $\mathrm{Kv} / \mathrm{Kh}$ ratio for Aquifer Zone $\mathrm{IB}_{2}$ (Water Table) is, in reality, higher than $1 / 1000$, then the average $\mathrm{Kv}$ value for Confining Zone $\Pi_{11} B_{1}-\Pi B_{2}$ (Tan Clay) would be lower than the calibrated value of $3 \times 10^{-3} \mathrm{ft} /$ day.

The $\mathrm{Kv} / \mathrm{Kh}$ ratio simulated for Layer 3, Aquifer Zone $\mathrm{IBB}_{1}$ (Barnwell/McBean) is $1 / 45$, while the conceptual ratio from the core was around $1 / 300$. Due to the highly stratified nature of this aquifer zone, the actual $\mathrm{Kv} / \mathrm{Kh}$ ratio is probably lower than the simulated value. The higher ratio of 1/45 is used due to the large model thickness of Layer 3 (50 to 70 feet near the F-Area Seepage Basins). In much of this area, the upper part of Aquifer Zone IB $_{1}$ (Barnwell/McBean) is of a coarser, sandier material than the lower part which ranges from a silt/clay/carbonate mixture to partially indurated limestone. Most of the monitoring wells from which hydraulic heads were obtained for calibration are screened in the upper part of this aquifer zone. Therefore, in areas with a significant vertical component of flow, such as near Fourmile Branch, the hydraulic 
head used for calibration may represent only the upper portion of the aquifer zone. However, in the model, the whole layer is simulated as one unit, and a fairly well connected aquifer is required to achieve calibration. For future modeling efforts, it is suggested to divide Aquifer Zone IIB $_{1}$ (Barnwell/McBean) into at least two layers.

The simulated hydraulic conductivity value of Confining Unit IIA-IIB (Green Clay) is fairly low. However, the value is within the reasonable range of unweathered marine clay as presented in Freeze and Cherry (1979) and several cores from the General Separations Area with laboratory vertical hydraulic conductivity measurements have similar values (Schiefer et al., 1993; WSRC, 1992a; and WSRC, 1992b). The large difference in hydraulic head (approximately 40 feet) between the upper part of Aquifer Unit IIA (Congaree) and the lower part of Aquifer Zone IB $_{1}$ (Barnwell/McBean) combined with the small thickness of Confining Unit IIA-IIB (Green Clay) suggests that this unit has a low vertical hydraulic conductivity.

However, the simulated vertical hydraulic conductivity value may be lower than the actual value due to:

1) the aforementioned simulated vertical hydraulic conductivity of Aquifer Zone IIB $_{1}$ (Barnwell/McBean) may be lower than in reality and is partially compensated for by Confining Unit IIA-IIB (Green Clay) being simulated as having a lower vertical hydraulic conductivity value; and

2) the exclusion of the aforementioned zone of low horizontal hydraulic conductivity recently delineated in an aquifer test in Aquifer Zone IB $_{1}$ (Barnwell/McBean). If the low hydraulic conductivity zone was included in the model, the simulated hydraulic heads in Layer 3, Aquifer Zone $\mathrm{IIB}_{1}$ (Barnwell/McBean) would be above calibration target values. To reduce the simulated heads, the vertical hydraulic conductivity of Confining Unit IIA (Green Clay) would be increased.

\subsubsection{Connection of Aquifer Zone $\mathrm{IB}_{1}$ (Barnwell/McBean) to Fourmile Branch}

Figures 1.3 through 1.5 show hydraulic head distributions for each aquifer zone near the F-Area Seepage Basins. Equipotential lines of Aquifer Zone $\mathbb{I B}_{1}$ (Barnwell/McBean) are roughly parallel to those of Aquifer Zone $\mathrm{IB}_{2}$ (Water Table) and to Fourmile Branch. Because there are no likely discharge areas on the other side of Fourmile Branch, the parallelism indicates that discharge from this aquifer zone is occurring at Fourmile Branch and that this discharge is a strong controlling factor over the hydraulic gradients within Aquifer Zone $\mathrm{IB}_{1}$ (Barnwell/McBean). During the modeling simulations, if the vertical resistance to flow between the aquifer zone and . Fourmile Branch was too great, water in Aquifer Zone $\mathrm{IIB}_{1}$ (Barnwell/McBean) in this area was simulated as flowing toward and discharging into Upper Three Runs Creek, further indicating that in reality, a good hydraulic connection exists.

During calibration, a group of wells near Fourmile Branch in Aquifer Zone $\mathrm{IBB}_{1}$ (Barnwell/McBean) (FSB-79C, FSB-102C, FSB-106C, and FSB-113C) were chronically simulated with higher hydraulic heads than observed, while a line of wells near the seepline and Fourmile Branch in Aquifer Zone $\mathrm{IB}_{2}$ (Water Table) were simulated with lower hydraulic heads than observed. Figure 4.2 shows a cross section from well cluster FSB-79, through Fourmile Branch, to well cluster FSB-115 (data from WSRC, 1992a). The hydraulic head in Aquifer Zone $\mathrm{IIB}_{1}$ (Barnwell/McBean) is approximately six feet lower than in Aquifer Zone $\mathrm{IIB}_{2}$ (Water Table). 
This is significant because cluster FSB-79 is laterally 300 feet from wetland discharge areas for Aquifer Zone $\mathrm{IIB}_{2}$ (Water Table) and 800 feet from Fourmile Branch, the ultimate discharge area for both aquifer zones. Well cluster FSB-115C is approximately 300 feet from Fourmile Branch. The hydraulic head in Aquifer Zone IIB $_{1}$ (Barnwell/McBean) is also relatively low considering Confining Zone $\mathrm{IBB}_{1}-\mathrm{IBB}_{2}$ (Tan Clay) is shown to be between the aquifer zone and Fourmile Branch. These attributes indicate the existence of a relatively low vertical conductivity between the two aquifer zones; probably from both Confining Zone $\mathrm{IB}_{1}-\mathrm{IIB}_{2}$ (Tan Clay) and anisotropy within each aquifer zone. But the attributes also indicate that Aquifer Zone $\mathbb{I B}_{1}$ (Barnwell/McBean) is well connected with Fourmile Branch; and suggests less vertical resistance to flow. In addition, the relatively low simulated hydraulic heads in Aquifer Zone $\mathrm{IB}_{2}$ (Water Table) near the seepline and Fourmile Branch suggested that the leakance values for both the drain and stream boundary conditions should be lowered.

The above situation was resolved by the following:

A) A drain leakance of 0.001 /day was used for the wetlands near the F-Area Seepage Basins. Leakance is hydraulic conductivity divided by the layer thickness. Using a conductance layer of one foot, the vertical hydraulic conductivity of this term would be similar to a silt or sandy clay. This value is considered reasonable considering the mucky layer which has developed over the wetland area due to organic buildup.

B) Visual inspection of the Fourmile Branch stream bed revealed interesting differences in stream characteristics. The stream bed was inspected in May, 1994 from C Road bridge (in the vicinity of column 35 in the regional model) to a point plant west of the F-Area Seepage Basins which corresponds approximately to column 8 of the regional model. From approximately column 21 of the regional model to the $C$ Road bridge, the stream bed was very sandy and the stream was relatively narrow and fast moving. This was also true for the area near the gravel road bridge crossing just downhill of the F-Area Seepage Basins. For the remainder of the area inspected, the stream bed was less sandy with finer grain material either making up the stream bed or covering it. Many of the these reaches had a slower moving current. Based on this one time inspection and the location of the aforementioned hydraulic head residuals in Aquifer Zone $\mathrm{IB}_{1}$

(Barnwell/McBean), columns 21 through 30 in the regional model were assigned higher stream conductance values than columns 1 through 20 .

C) To allow greater connection between Fourmile Branch and Aquifer Zone $\mathrm{IIB}_{1}$ (Barnwell/McBean), Zone 12 was created within Layer 2, Confining Zone $\mathrm{IBB}_{1}-\mathrm{IBB}_{2}$ (Tan Clay). Zone 12 is defined as the cells which are under Fourmile Branch and which also are in columns 21 through 30 of the regional model (Figure 3.1). This zone was assigned the same horizontal and vertical hydraulic conductivities as Aquifer Zone $\mathrm{IBB}_{1}$ (Barnwell/McBean) thus, mathematically removing Confining Zone $\mathrm{IIB}_{1}-\mathrm{IIB}_{2}$ (Tan Clay) from beneath Fourmile Branch at this location. Column 30 was selected because it corresponds to the edge of the model section modified for this modeling effort. Column 21 was selected based on the its general proximity to the aforementioned hydraulic head residuals in Aquifer Zone $\mathrm{IB}_{1}$ (Barnwell/McBean) and by the aforementioned visual inspection of the stream bed of Fourmile Branch. GeoTrans (1993) has a higher vertical hydraulic conductivity zone under Fourmile Branch for regional model columns 31 . through 90; mostly near the H-Area Seepage Basins. 
D) Also to allow greater connection between Fourmile Branch and Aquifer Zone $\mathrm{IBB}_{1}$ (Barnwell/McBean), stream boundary conditions were added to Confining Zone $\mathrm{IBB}_{1}-\mathrm{IBB}_{2}$ (Tan Clay) between columns 16 and 30 within the regional model. The boundary condition stream elevation remained the same for both layers and the stream surface area was divided between the two layers. Column 30 was selected because it corresponds to the edge of the model section modified for this modeling effort. Column 16 was chosen based on the calculated difference between the estimated stream bottom elevation and the estimated elevation of the top of Confining Zone $\mathrm{IBB}_{1}-\mathrm{IB}_{2}$ (Tan Clay). For much of the western two-thirds of the regional model area, this difference is small, especially compared to the accuracy of the estimates.

Information from the GIS generated model structure for these model columns is presented in Table 4.2. The elevation of Confining Zone $\mathrm{IB}_{1}-\mathrm{IB}_{2}$ (Tan Clay) in this area is not accurately known. The estimate for the top of Confining Zone $\mathrm{IIB}_{1}-\mathrm{IBB}_{2}$ (Tan Clay) near columns 20 through 30 is greatly affected by the interpretation of information collected from well FSB-116C. Based on this data, the top of Confining Zone $\mathrm{IB}_{1}-\mathrm{IB}_{2}$ (Tan Clay) is said to be approximately five feet lower than the data from well FSB-115C indicates (WSRC, 1992a). However, the data collected from FSB-116C is, at best, vague on the location of Confining Zone $\mathrm{IB}_{1}-\mathrm{IIB}_{2}$ (Tan Clay). The estimated elevation of the top of Confining Zone $\mathrm{IIB}_{1}-\mathrm{IB}_{2}$ (Tan Clay) without the use of the FSB-116C interpretation for each affected cell is shown in Table 4.2. These elevations are within three feet of the estimated bottom of Fourmile Branch specified in columns 16 through 30 . For this modeling effort, three feet is considered a small enough difference between the top of Confining Zone $\mathrm{IB}_{1}-\mathrm{IB}_{2}$ (Tan Clay) and the bottom of Fourmile Branch to consider a connection between them. This decision is prompted by the aforementioned hydraulic heads and based on:

1) stream elevation is based on air photos of a heavily vegetated area;

2) stream bed bottom is one to two feet below the stream elevation;

3) stream downcutting and then filling with alluvium may allow a deeper zone of more permeable material to lie below the stream bottom;

4) elevation of Confining Zone $\mathrm{IB}_{1}-\mathrm{IB}_{2}$ (Tan Clay) is not known accurately;

5) Confining Zone $\mathrm{IB}_{1}-\mathrm{IB}_{2}$ (Tan Clay) could consist of a relatively thin competent layer that has been dissected by Fourmile Branch.

All other boundary assignments were the same as GeoTrans (1993).

\subsubsection{Congaree and Upper Three Runs Creek}

Aquifer Unit IIA (Congaree) and the parameters affecting its discharge to Upper Three Runs Creek and associated wetlands were not modified in this modeling effort. The simulated hydraulic head for this unit in GeoTrans (1993) is several feet lower than measured hydraulic head. The reason may be related to the use of Upper Three Runs Creek elevations as a factor in assignment of constant head boundary values for the model. The hydraulic head beneath the creek may be several feet higher than the creek bed elevation.

Aquifer Unit IIA (Congaree) was not modified because: A) the objectives of this modeling effort are not directly dependent on this unit B) the hydraulic connection between this unit and the aquifer zones overlying it is small; and C) the hydraulic head difference between the upper part of Aquifer Unit IIA (Congaree) and the lower part of Aquifer Zone $\mathrm{IB}_{1}$ (Bamwell/McBean) is large, 
thus a small difference in simulated hydraulic head does not create a significant difference in the vertical hydraulic gradient between these aquifer units. The simulated hydraulic head in Aquifer Unit IIA (Congaree) for this modeling effort is within 0.25 feet of those reported in GeoTrans (1993) for all wells (Section 4.3.1).

\subsubsection{Recharge Rates}

The recharge rates used in this modeling effort are the same as GeoTrans (1993). The model wide rate of 15 inches per year is compatible with water budget studies and past modeling efforts. The rate for the capped areas is based on a 95 percent reduction in recharge.

\subsubsection{Changes in Layer Thickness from GeoTrans (1993)}

Layer thicknesses used in this modeling effort are the same as GeoTrans (1993) with the exception of two areas. One area is in the northwest portion of the modeled area near the BRR well series. The thickness of Confining Zone $\mathrm{IBB}_{1}-\mathrm{IIB}_{2}$ (Tan Clay) in this area is controlled by the report that no confining unit was encountered during the drilling of well IDL-3A. Through the use of the GIS system, a large area was assigned very low thicknesses for this layer. Since the modeling effort in GeoTrans (1993), several wells have been installed near well IDL-3A. Confining Zone $\mathrm{IB}_{1}-\mathrm{IIB}_{2}$ (Tan Clay) thicknesses of 6 to 16 feet were encountered in these wells. Therefore, Confining Zone $\mathrm{IB}_{1}-\mathrm{IB}_{2}$ (Tan Clay) thicknesses were increased in the area of these new wells. Figure 4.3 shows the model thickness of Confining Zone $\mathrm{IB}_{1}-\mathrm{IIB}_{2}$ (Tan Clay) and the area where the thickness was modified. The modified area corresponds to cells within regional model columns 1 through 23 for rows 38 through 44 and rows 1 through 37 for columns 18 through 23. The thickness of Confining Zone $\mathrm{IIB}_{1}-\mathrm{IIB}_{2}$ (Tan Clay) in this region was increased to seven feet. If the thickness was originally over seven feet, it was not modified. The same thickness which was added to Confining Zone $\mathrm{IIB}_{1}-\mathrm{IIB}_{2}$ (Tan Clay) was subtracted from Aquifer . Zone $\mathrm{IB}_{2}$ (Water Table). The effect of this increased Confining Zone $\mathrm{IB}_{1}-\mathrm{IBB}_{2}$ (Tan Clay) thickness was the simulated increase in hydraulic head at the BRR well series.

The second modification was the reduction in thickness of Confining Unit IIA-IIB (Green Clay) in the wetland area just downgradient of the F-Area Seepage Basins. The area corresponds to regional model columns 10 through 30 and rows 55 through 65 (Figure 4.4). Estimates of the thickness of this unit from well drilling information near the F-Area Seepage Basins range from two to five feet. However, the estimate from well FSB-115C is 17 feet (WSRC, 1992a). From review of the Geologic Field Log for this well, it looks as if the lower permeability zone within Aquifer Zone $\mathrm{IBB}_{1}$ (Barnwell/McBean) was included in Confining Unit IIA-IIB (Green Clay). Because this is inconsistent with the way this unit is delineated for the rest of the modeled area, the thickness was reduced to five feet. If the thickness for a cell was originally under five feet, it was not modified. The same thickness which was subtracted from Confining Unit IIA-IIB (Green Clay) was added to Aquifer Zone IIB $_{1}$ (Barnwell/McBean). This change in thickness had little effect on model results. 


\subsection{Evaluation of Calibration}

\subsubsection{Hydraulic Head and Hydraulic Gradients}

Hydraulic head distributions simulated in the regional model near the F-Area Seepage Basins are presented for each aquifer zone in Figures 4.5, 4.6, and 4.7. Hydraulic head distributions for the complete model area are in Appendix 2. The simulated hydraulic heads are similar to both measured hydraulic heads and hydraulic heads estimated from the area conceptual model. Horizontal hydraulic gradients, including the groundwater divides in Aquifer Zone $\mathrm{IB}_{2}$ (Water Table) and Aquifer Zone $\mathrm{IBB}_{1}$ (Barnwell/McBean), and vertical hydraulic gradients between aquifer zones are reasonable.

Residual hydraulic head (observed head minus simulated head) values for the calibrated regional model are listed in Table 4.3. Table (4.3a) lists wells within the modified area while Table (4.3b) lists the wells outside of the modified area. For the unmodified portion of the model, the difference between the head residuals and those listed in GeoTrans (1993) are also given. . Figures 4.8 through 4.10 show the difference in hydraulic head values between the current modeling effort and the model in GeoTrans (1993) for both the area near the H-Area Seepage Basins and for Aquifer Unit IIA (Congaree). Because these differences are small near the H-Area Seepage Basins and for Aquifer Unit ПА (Congaree), the recalibration of the area near the F-Area Seepage Basins for this project is considered justified. The calibration evaluation will concentrate : on the modified area, however, residual head maps and comparisons for the whole model are given in Appendix 2.

The wells from which hydraulic heads were used for calibration in this modeling effort are the same as those wells listed in GeoTrans (1993) except for the exclusion of wells FSB-114C, FSB91C, FBP-2A, FBP-3A, FBP-4, and FNB-4. These wells are suspected of having sand packs constructed across confining zones. Several wells within the unmodified portions of the model are also suspect, however they were left as in GeoTrans (1993).

Figures 4.11 through 4.16 present the residual hydraulic head areal distributions, residual hydraulic head histograms, and line graphs for simulated versus observed hydraulic heads within the modified area for each aquifer zone. Table 4.4 gives the residual head statistics from the model.

The residual hydraulic head maps contain well symbols for which the size is directly proportional to the residual value. Black symbols indicate that the simulated hydraulic head is lower than the measured hydraulic head, while no shading indicates that the simulated hydraulic head is higher than the measured hydraulic head. The residual hydraulic heads for Aquifer $\mathrm{Zone} \mathrm{IIB}_{2}$ (Water Table) near the F-Area Seepage Basins are very low and well distributed (Figure 4.11). Most of the wells with high residuals are FTF and FCA wells in F-Area near the modified boundary for this modeling effort. The wells were installed in the 1970's and 1980's; detailed well sandpack intervals are not readily available. Of the 12 wells with residuals greater than 1.0 feet in this aquifer zone, eight are located within columns 27 through 30 near the modified boundary for this modeling effort. Figure 4.12 shows the residual hydraulic head areal distribution for Aquifer Zone $\mathrm{IBB}_{1}$ (Barnwell/McBean) near the F-Area Seepage Basins. The residuals for this aquifer zone are 
not as low or as well distributed as for Aquifer Zone $\mathrm{IIB}_{2}$ (Water Table), however, the fit is reasonably good. The main area of bias is near Fourmile Branch, directly plant south of the basins. Methods used to reduce these residuals are given in Section 4.2.3. The incorporation of the aforementioned zone of lower hydraulic conductivity within this zone may help reduce the residuals in future modeling efforts (Section 4.1).

The residual hydraulic head histogram for Aquifer Zone $\mathrm{IB}_{2}$ (Water Table) (Figure 4.13) shows a narrow, mound shaped distribution centered around zero. The residual hydraulic head histogram for Aquifer Zone $\mathrm{IB}_{1}$ (Barnwell/McBean) (Figure 4.14) shows a distribution slightly skewed toward the negative residual values (simulated higher than observed) with maximum frequencies at zero and negative one. Each category within Figures 4.13 and 4.14 is bounded by 0.5 feet to either side of the category name. For example, category " 0 " includes all points with residuals between 0.5 and -0.5 feet; category " 1 " includes all points with residuals between 0.5 and 1.5 feet; etc.

The line graph of simulated versus observed hydraulic heads for Aquifer Zone II $_{2}$ (Water Table) also shows a well distributed fit of simulated to observed heads (Figure 4.15). The scatter on the right side of the graph is from the aforementioned FTF and FCA well series near the modified area boundary. Two lines are shown on the graph, a 45 degree line showing where the points for a perfect fit would plot, and a line through the points using a least-squares line fit. The line graph of simulated versus observed hydraulic heads for Aquifer Zone $\mathrm{IBB}_{1}$ (Barnwell/McBean) shows a reasonably well distributed fit (Figure 4.16). Two points on the left hand side of the graph are not well distributed. These correspond to the aforementioned area near Fourmile Branch.

Residual information for Aquifer Unit IIA (Congaree) is given in Appendix 2. Generally the simulated hydraulic heads are several feet lower than the observed heads. See Section 4.2.4 for a discussion on this topic.

\subsubsection{Particle Tracking}

Particle tracking was used to provide an indication of the simulated advective trajectory of solute and the approximate horizontal travel times under current conditions (seepage basins not operational). Figures 4.17 and 4.18 show horizontal particle traces for Aquifer Zone $\mathrm{IBB}_{2}$ (Water Table) and Aquifer Zone $\mathrm{IB}_{1}$ (Barnwell/McBean) respectively. The approximate advective travel time from the basins to Fourmile Branch within Aquifer Zone $\mathrm{IB}_{2}$ (Water Table) is simulated to be five years, which is similar to other estimates. The $10,000 \mathrm{pCi} / \mathrm{ml}$ tritium plume from 1992 is also shown in Figure 4.17. It is interesting to note the relatively large distribution of this plume as compared to advective flow without the seepage basins operational.

Particle tracking was also used to make sure excessive particles were not entering Aquifer Unit IIA (Congaree). Historically only very limited amounts of tritium has been detected in this aquifer unit. The number of particles simulated to enter Aquifer Unit IIA (Congaree) was very small. 


\subsubsection{Water Flux to Fourmile Branch}

No flow rate measurements were available for Fourmile Branch which encompassed the modified portion of the model. The model estimated water flux between Stations 3 and 4 which encompasses an area near the H-Area Seepage Basins is 0.62 cubic feet per second (cfs). This is similar to that of the GeoTrans (1993) model (0.65 cfs) and compares favorably to the $1 \mathrm{cfs}$ measured for discharge from both sides of the stream reach. The model estimated flux for the area near the F-Area Seepage Basins is $0.86 \mathrm{cfs}$, which seems reasonable.

\subsection{Regional Model with Seepage Basins Operational}

After calibration of the regional model under current conditions, a steady-state simulation with the seepage basins operational was performed. All parameters were the same between the two simulations (operational versus not operational seepage basins) except:

1) each seepage basin was assigned a seepage rate based on an average during operation (GeoTrans, 1993). The F-Area Seepage Basin rate was 212.5 inches per year for all areas within a basin; and

2) the burial ground caps were removed and the area was assigned a recharge rate of 15 inches per year.

The simulated mounding due to basin operation was low (less than five feet) near the F-Area Seepage Basins; similar to measurements during basin operation.

Particle tracking was used to provide an indication of the advective trajectory of solute under seepage basin operational conditions. Figure 4.19 shows horizontal particle traces for Aquifer Zone $\mathrm{IIB}_{2}$ (Water Table) along with the $10,000 \mathrm{pCi} / \mathrm{ml}$ tritium plume from 1992 . It is interesting . to note that the particle traces are similar to the distribution of this plume. Horizontal particle traces for Aquifer Zone IBB $_{1}$ (Barnwell/McBean) are shown in Figure 4.20. Location of the 1992 $10,000 \mathrm{pCi} / \mathrm{ml}$ tritium plume within Aquifer Zone $\mathrm{IB}_{1}$ (Barnwell/McBean) is due to the leakage of tritium from Aquifer Zone $\mathrm{IIB}_{2}$ (Water Table). Horizontal particle tracking uses the horizontal (two-dimensional) velocity vectors, simulated within each layer, to advance the particle over time. 


\begin{tabular}{|lr|}
\hline Savannah River Site & WSRC-RP-95-237 \\
Groundwater Model Recalibration and & Revision 0 \\
Remediation Well Network Design at the F-Area Seepage Basins (U) & Page 29 of 124 \\
\hline
\end{tabular}

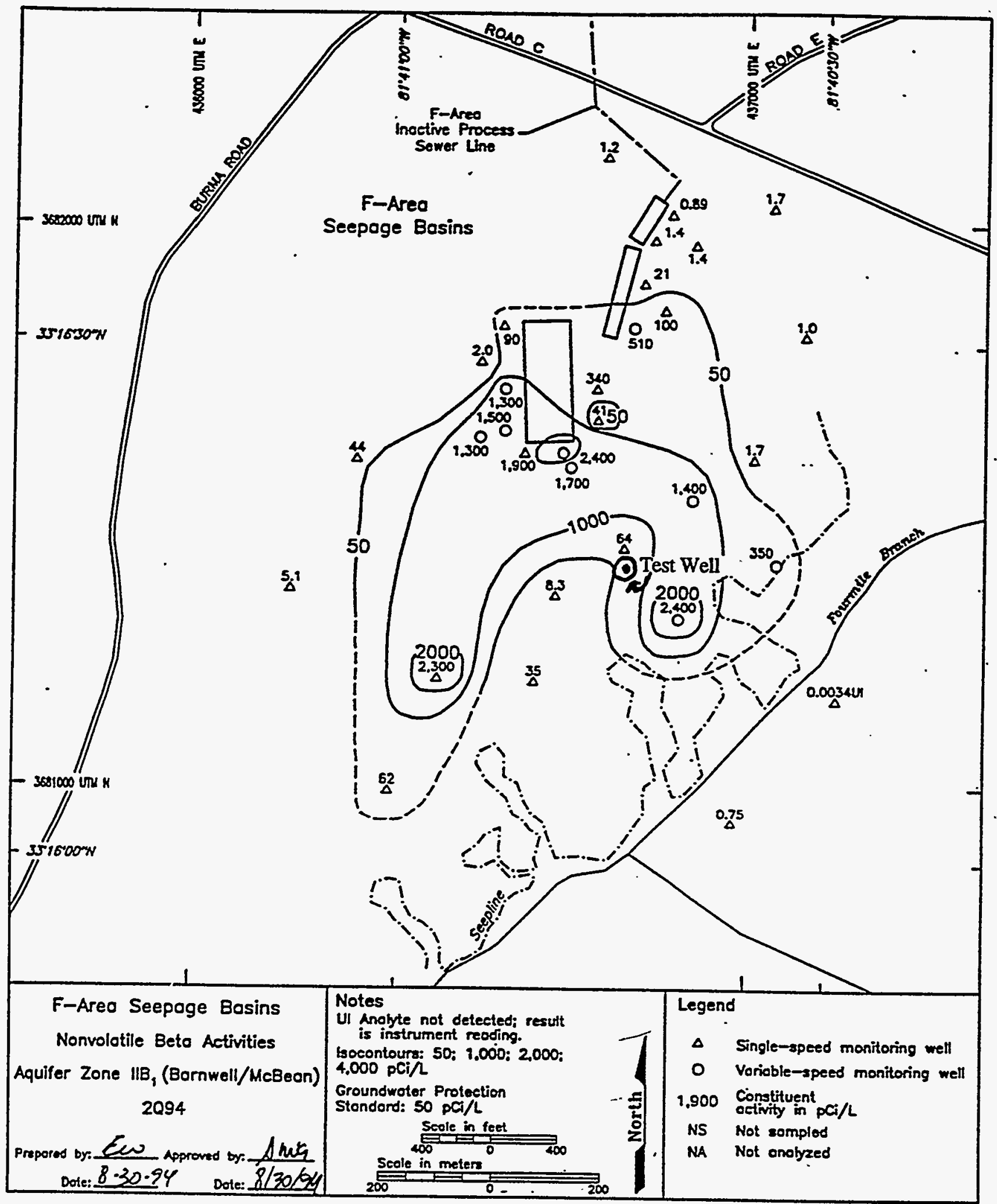

Figure 4.1. Nonvolatile Beta Activities in Aquifer Zone IBB1 (Barnwell/McBean) at the F-Area Seepage Basins, second quarter, 1994 with the location of test well FSB-0PC. (modified from WSRC, 1991) 
Table 4.1. Model parameters used for flow model calibration. The parameters are for regional model columns 1 through 30. Zone 12 is defined as the cells which are under Fourmile Branch and which also are in regional model columns 21 through 30. See GeoTrans (1993) for parameters near the H-Area Seepage Basins.

\begin{tabular}{|c|c|c|c|}
\hline $\begin{array}{l}\text { Hydrostratigraphic } \\
\text { Unit/Entity }\end{array}$ & $\begin{array}{l}\text { Model } \\
\text { Layer }\end{array}$ & Hydraulic Parameter & $\begin{array}{l}\text { Calibrated } \\
\text { Estimate }\end{array}$ \\
\hline $\begin{array}{l}\text { Aquifer Zone } \mathrm{IIB}_{2} \\
\text { (Water Table) }\end{array}$ & 1 & $\begin{array}{l}\mathrm{Kh} \\
\mathrm{Kv}\end{array}$ & $\begin{array}{l}40 \mathrm{ft} / \text { day } \\
0.04 \mathrm{ft} / \text { day }\end{array}$ \\
\hline $\begin{array}{l}\text { Confining Zone } \mathrm{IB}_{1}-\mathrm{IB}_{2} \\
\text { (Tan Clay) }\end{array}$ & 2 & $\begin{array}{c}\mathrm{Kv} \\
\mathrm{Kh} \\
\mathrm{Kv}-\mathrm{Zone} 12 \\
\mathrm{Kh} \text { - Zone } 12\end{array}$ & $\begin{array}{c}3.0 \times 10-3 \mathrm{ft} / \text { day } \\
0.4 \mathrm{ft} / \text { day } \\
0.2 \mathrm{ft} / \text { day } \\
9 \mathrm{ft} / \text { day }\end{array}$ \\
\hline $\begin{array}{l}\text { Aquifer Zone } \mathbb{I B}_{1} \\
\text { (Bamwell/McBean) }\end{array}$ & 3 & $\begin{array}{l}\text { Kh } \\
\text { Kv }\end{array}$ & $\begin{array}{l}9 \mathrm{ft} / \text { day } \\
0.2 \mathrm{ft} / \text { day }\end{array}$ \\
\hline $\begin{array}{l}\text { Confining Unit IIA-IIB } \\
\text { (Green Clay) }\end{array}$ & 4 & $\begin{array}{l}\text { Kv } \\
\text { Kh }\end{array}$ & $\begin{array}{l}1.0 \times 10-6 \mathrm{ft} / \text { day } \\
1.0 \times 10-3 \mathrm{ft} / \text { day }\end{array}$ \\
\hline $\begin{array}{l}\text { Aquifer Unit IIA } \\
\text { (Congaree) }\end{array}$ & 5 & $\begin{array}{l}\mathrm{Kh} \\
\mathrm{Kv}\end{array}$ & $\begin{array}{l}38 \mathrm{ft} / \text { day } \\
3.8 \mathrm{ft} / \text { day }\end{array}$ \\
\hline Recharge & $\begin{array}{c}1-5 \\
1\end{array}$ & $\begin{array}{c}\text { Recharge Rate - Model Wide } \\
\text { Capped Areas }\end{array}$ & $\begin{array}{l}15 \mathrm{in} / \mathrm{yr} \\
0.75 \mathrm{in} / \mathrm{yr}\end{array}$ \\
\hline Wetlands & $\begin{array}{l}1 \\
3 \\
5\end{array}$ & $\begin{array}{l}\text { Drain Leakance - 4mile and UTRC } \\
\text { Drain Leakance-UTRC } \\
\text { Drain Leakance-UTRC }\end{array}$ & $\begin{array}{c}0.001 / \text { day } \\
0.005 / \text { day } \\
0.01 \& 0.027 / \text { day }\end{array}$ \\
\hline Streams & $\begin{array}{c}1 \\
1,2 \\
5\end{array}$ & $\begin{array}{l}\text { Stream Leakance - 4mile } \\
\text { Stream Leakance - Zone } 12 \text { area } \\
\text { Stream Leakance -UTRC }\end{array}$ & $\begin{array}{l}0.03 / \text { day } \\
0.5 / \text { day } \\
2.0 / \text { day }\end{array}$ \\
\hline Intermittent Streams & 1,3 & Drain Leakance & $0.8 /$ day \\
\hline
\end{tabular}

$\mathrm{Kh}=$ horizontal hydraulic conductivity; 4 mile $=$ Fourmile Branch;
$\mathrm{Kv}=$ vertical hydraulic conductivity

UTRC = Upper Three Runs Creek 

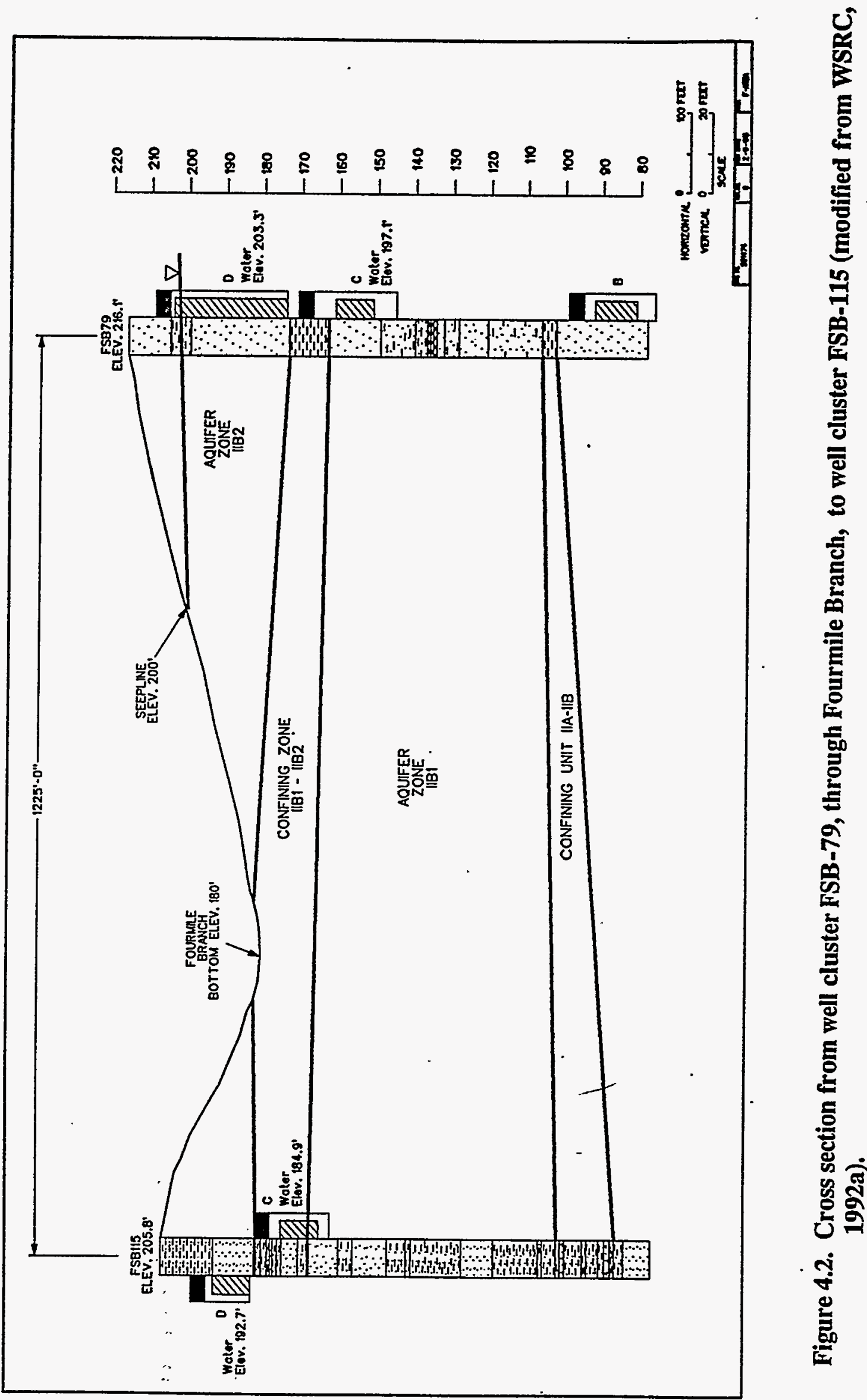


\begin{tabular}{|c|c|c|c|c|c|c|c|}
\hline \multicolumn{2}{|c|}{ Table 4.2. Model elevations of Fourmile Creek bed and top of Confining Zone $\left\|B_{1}-\right\| B_{2}$} & and the difference $b$ & etween the & $m$ in feet. & & & \\
\hline & & & & & & & \\
\hline & & & & & & Top Tan & \\
\hline & & Stream & Top & & & Clay & Difference \\
\hline & & Bottom & $\operatorname{Tan}$ & Original & & not using & with no \\
\hline Column & Row & Elevation & Clay & Difference & & FSB116C & FSB116C \\
\hline 1 & 71 & 164.27 & 163.06 & 1.21 & & & 1.21 \\
\hline 1 & 72 & 163.42 & 162.64 & 0.78 & & & 0.78 \\
\hline 2 & 70 & 166.58 & 163.3 & 3.28 & & & 3.28 \\
\hline 2 & 71 & 165.23 & 162.96 & 2.27 & & & 2.27 \\
\hline 3 & 69 & 167.14 & 163.52 & 3.62 & & & 3.62 \\
\hline 3 & .70 & 167.04 & 163.24 & 3.8 & & & 3.8 \\
\hline 4 & 68 & 169.17 & 163.7 & 5.47 & & & 5.47 \\
\hline 4 & 69 & 168.64 & 163.79 & 4.85 & & & 4.85 \\
\hline 5 & 67 & 171.01 & 164.09 & 6.92 & & & 6.92 \\
\hline 5 & 68 & 170.22 & 164.22 & 6 & & & 6 \\
\hline 6 & 67 & 171.93 & 164.58 & 7.35 & & & 7.35 \\
\hline 7 & 67 & 172.75 & 164.99 & 7.76 & & & 7.76 \\
\hline 8 & 67 & 173.57 & 165.34 & 8.23 & & & 8.23 \\
\hline 9 & 66 & 174.02 & 165.51 & 8.51 & & & 8.51 \\
\hline 9 & 67 & 173.72 & 165.62 & 8.1 & & & 8.1 \\
\hline 10 & 66 & 174.59 & 165.76 & 8.83 & & & 8.83 \\
\hline 11 & 65 & 175.29 & 166.56 & 8.73 & & & 8.73 \\
\hline 11 & 66 & 174.99 & 166.45 & 8.54 & & & 8.54 \\
\hline 12 & 65 & 175.87 & 168.37 & 7.5 & & & 7.5 \\
\hline 13 & .65 & 176.43 & 170.17 & 6.26 & & & 6.26 \\
\hline 14 & 65 & 177.15 & 171.99 & 5.16 & & & 5.16 \\
\hline 15 & 65 & \begin{tabular}{|l|l|} 
& 177.65 \\
\end{tabular} & 173.78 & 3.87 & & & 3.87 \\
\hline \multicolumn{8}{|c|}{ 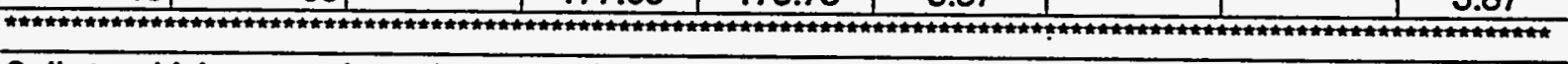 } \\
\hline \multicolumn{8}{|c|}{ Cells to which stream boundary conditions were added in Confining Zone $\left\|B_{1}-\right\| B_{2}$ (TanClay) } \\
\hline 16 & 65 & \begin{tabular}{|l|l|} 
& 178.11 \\
\end{tabular} & 175.59 & 2.52 & & & 2.52 \\
\hline 16 & 64 & 178.44 & 175.71 & 2.73 & & & 2.73 \\
\hline 17 & 64 & 178.99 & 177.51 & 1.48 & & & 1.48 \\
\hline 18 & 64 & 179.47 & 179.26 & 0.21 & & & 0.21 \\
\hline 18 & 62 & 179.87 & 178.67 & 1.2 & & & 1.2 \\
\hline 19 & 63 & 180.57 & 178.76 & 1.81 & & & 1.81 \\
\hline 20 & 62 & 181.45 & 176.93 & 4.52 & & 180 & 1.45 \\
\hline 20 & 63 & 181.04 & 178.12 & 2.92 & & & 2.92 \\
\hline 21 & 62 & 182.16 & 176.25 & 5.91 & $=$ & 180 & 2.16 \\
\hline 22 & 62 & 183.13 & 175.57 & 7.56 & & 181 & 2.13 \\
\hline 23 & 61 & 183.72 & 175.94 & 7.78 & & 181 & 2.72 \\
\hline 23 & 62 & 183.33 & 175.61 & 7.72 & & 181 & 2.33 \\
\hline 24 & 61 & 184.41 & 178.03 & 6.38 & & 182 & 2.41 \\
\hline 25 & 60 & 185.43 & 180.54 & 4.89 & & 183 & 2.43 \\
\hline 25 & 61 & 185.04 & -180.19 & 4.85 & & 183 & 2.04 \\
\hline 26 & 60 & 185.95 & 182.8 & 3.15 & & 184 & 1.95 \\
\hline 27 & 60 & 186.92 & 183.06 & 3.86 & & 185 & 1.92 \\
\hline 28 & 60 & 187.36 & 182.8 & 4.56 & & 186 & 1.36 \\
\hline 28 & 59 & 187.72 & 186.19 & 1.53 & & & 1.53 \\
\hline 29 & 60 & 188.47 & 182.54 & 5.93 & & 188 & 0.47 \\
\hline
\end{tabular}




\begin{tabular}{|c|c|c|c|c|c|c|c|c|}
\hline \multicolumn{9}{|c|}{ Table 4.2 Continued. } \\
\hline & & & & & & & & \\
\hline 29 & 59 & & 188.15 & 185.92 & 2.23 & & & 2.23 \\
\hline 30 & 60 & & 188.91 & 182.82 & 6.09 & & 190 & -1.09 \\
\hline \multicolumn{9}{|c|}{ 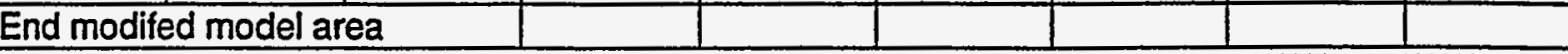 } \\
\hline \multicolumn{9}{|c|}{ 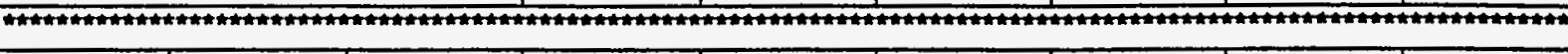 } \\
\hline & & & & & & & & \\
\hline 31 & 60 & & 189.29 & 183.98 & 5.31 & & & 5.31 \\
\hline 32 & 60 & & 189.64 & 185.14 & 4.5 & & & 4.5 \\
\hline 33 & 61) & & 190.11 & 186.59 & 3.52 & & & 3.52 \\
\hline 33 & 60 & & .189 .93 & 186.3 & 3.63 & & & 3.63 \\
\hline 34 & 60 & & 190.32 & 187.46 & 2.86 & & & 2.86 \\
\hline 35 & 60 & & 190.65 & 188.62 & 2.03 & & & 2.03 \\
\hline 36 & 60 & & 191.38 & 189.78 & 1.6 & & & 1.6 \\
\hline 36 & 59 & & 194.02 & 189.49 & 4.53 & & & 4.53 \\
\hline 36 & 58 & & 195.54 & 189.2 & 6.34 & & & 6.34 \\
\hline 36 & 56 & & 197.39 & 194.82 & 2.57 & & & 2.57 \\
\hline 36 & 61 & & 191.21 & 190.07 & 1.14 & & & 1.14 \\
\hline 36 & 57 & & 196.49 & 190.91 & 5.58 & & & 5.58 \\
\hline 37 & 56 & & 198.4 & 196.2 & 2.2 & & & 2.2 \\
\hline 37 & 61 & & 191.61 & 191.23 & 0.38 & & & 0.38 \\
\hline 38 & 61 & & 192.05 & 192.39 & -0.34 & & & -0.34 \\
\hline 38 & 55 & & 201.9 & 195 & 6.9 & & & 6.9 \\
\hline 38 & 62 & & 192.28 & 192.52 & -0.24 & & & -0.24 \\
\hline 39 & 62 & & 192.54 & 193.6 & -1.06 & & & -1.06 \\
\hline 40 & 63 & & 193.08 & 193.11 & -0.03 & & & -0.03 \\
\hline 40 & 62 & & 192.71 & 194.68 & -1.97 & & & -1.97 \\
\hline 41 & 64 & & 193.33 & 192.62 & 0.71 & & & 0.71 \\
\hline 41 & 63 & & 193.16 & 194.19 & $-1,03$ & & & -1.03 \\
\hline 42 & 64 & & 193.66 & 193.7 & -0.04 & & & -0.04 \\
\hline 43 & 64 & & 193.83 & 194.78 & -0.95 & & & -0.95 \\
\hline 43 & 65 & & 193.99 & 194.3 & -0.31 & & & -0.31 \\
\hline 44 & 65 & & 194.35 & 194.37 & -0.02 & & & -0.02 \\
\hline 45 & 66 & & 194.67 & 196.73 & -2.06 & & & -2.06 \\
\hline 45 & 65 & & 194.48 & 195.68 & -1.2 & & & -1.2 \\
\hline 46 & 67 & & 194.99 & 204.28 & -9.29 & & & -9.29 \\
\hline 46 & 66 & & 194.92 & 195.69 & -0.77 & & & -0.77 \\
\hline 48 & 66 & & 195.65 & 196.96 & -1.31 & & & -1.31 \\
\hline 48 & 67 & & 195.54 & 195.72 & -0.18 & & & -0.18 \\
\hline 49 & 66 & & 195.91 & 196.05 & -0.14 & . & & -0.14 \\
\hline 50 & 66 & & 196.29 & 195.91 & $0.38^{-}$ & & & 0.38 \\
\hline 51 & 66 & & 196.77 & 195.76 & 1.01 & & & 1.01 \\
\hline 52 & 66 & & 197.06 & 195.6 & 1.46 & & & 1.46 \\
\hline 53 & 66 & & 197.86 & 195.45 & 2.41 & & & 2.41 \\
\hline 54 & 66 & & 198.24 & 195.3 & 2.94 & & & 2.94 \\
\hline 55 & 66 & & 198.94 & 190.4 & 8.54 & & & 8.54 \\
\hline 56 & 66 & & 199.76 & 191.2 & 8.56 & & & 8.56 \\
\hline 57 & 66 & & 201.16 & 188.08 & 13.08 & & & 13.08 \\
\hline 58 & 67 & & 202.48 & 191.08 & 11.4 & & & 11.4 \\
\hline 58 & 66 & & 201.91 & 189.63 & 12.28 & & & 12.28 \\
\hline 59 & 69 & & 204.85 & 193.47 & 11.38 & & & 11.38 \\
\hline
\end{tabular}




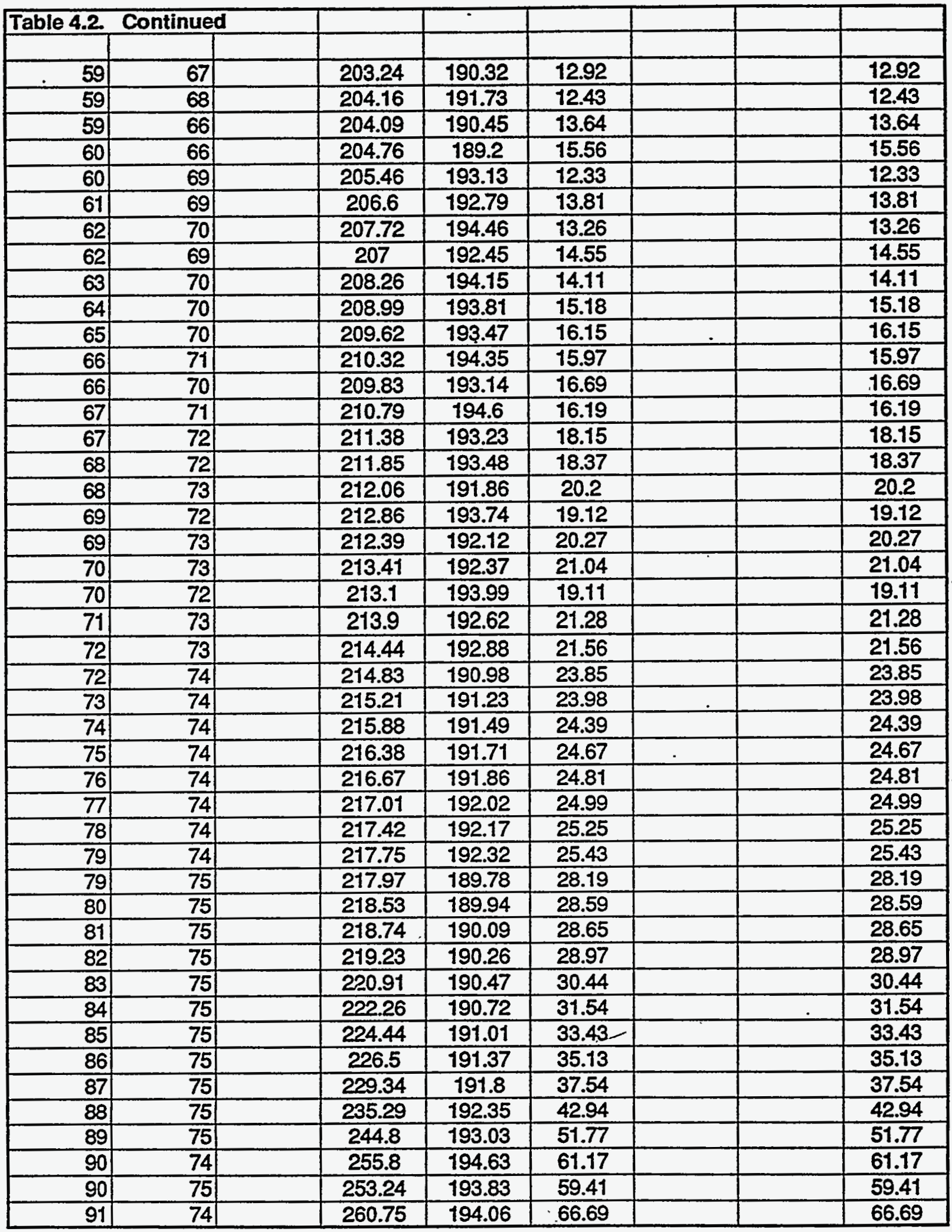


(

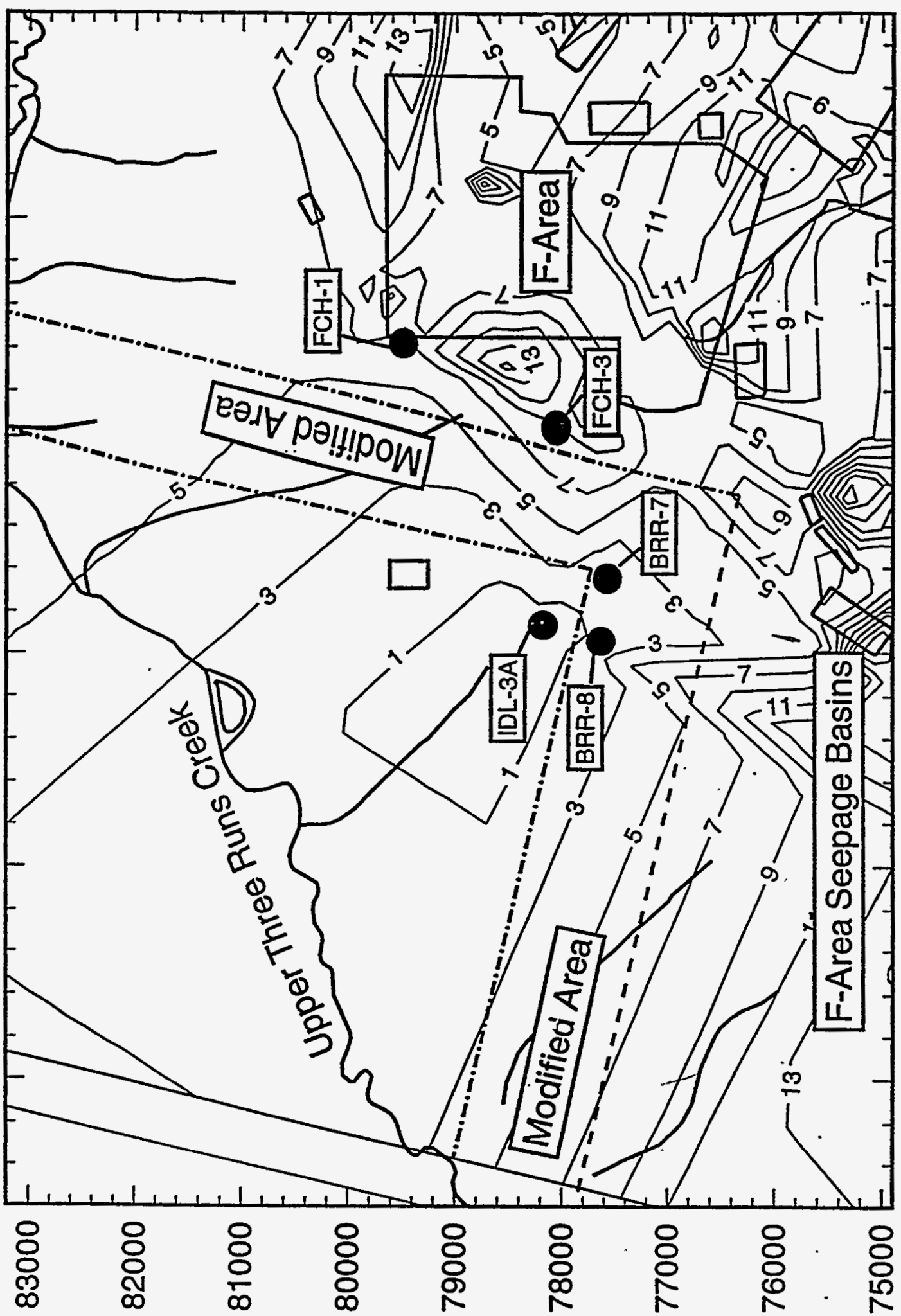

$\stackrel{9}{*}$

3

dु

등

๖

里

\begin{tabular}{l}
8 \\
8 \\
\hline
\end{tabular}

氖

ए

\$

o

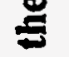

롤

○

8 홍.

N

E.

నิ

Uั

हี

8

急

틀

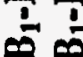

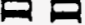

올

옹ำ

○ 올

8

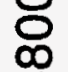

동 응

U己

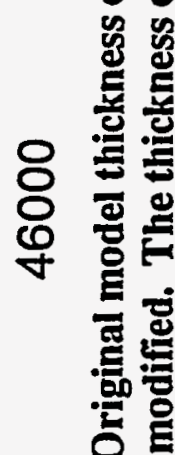




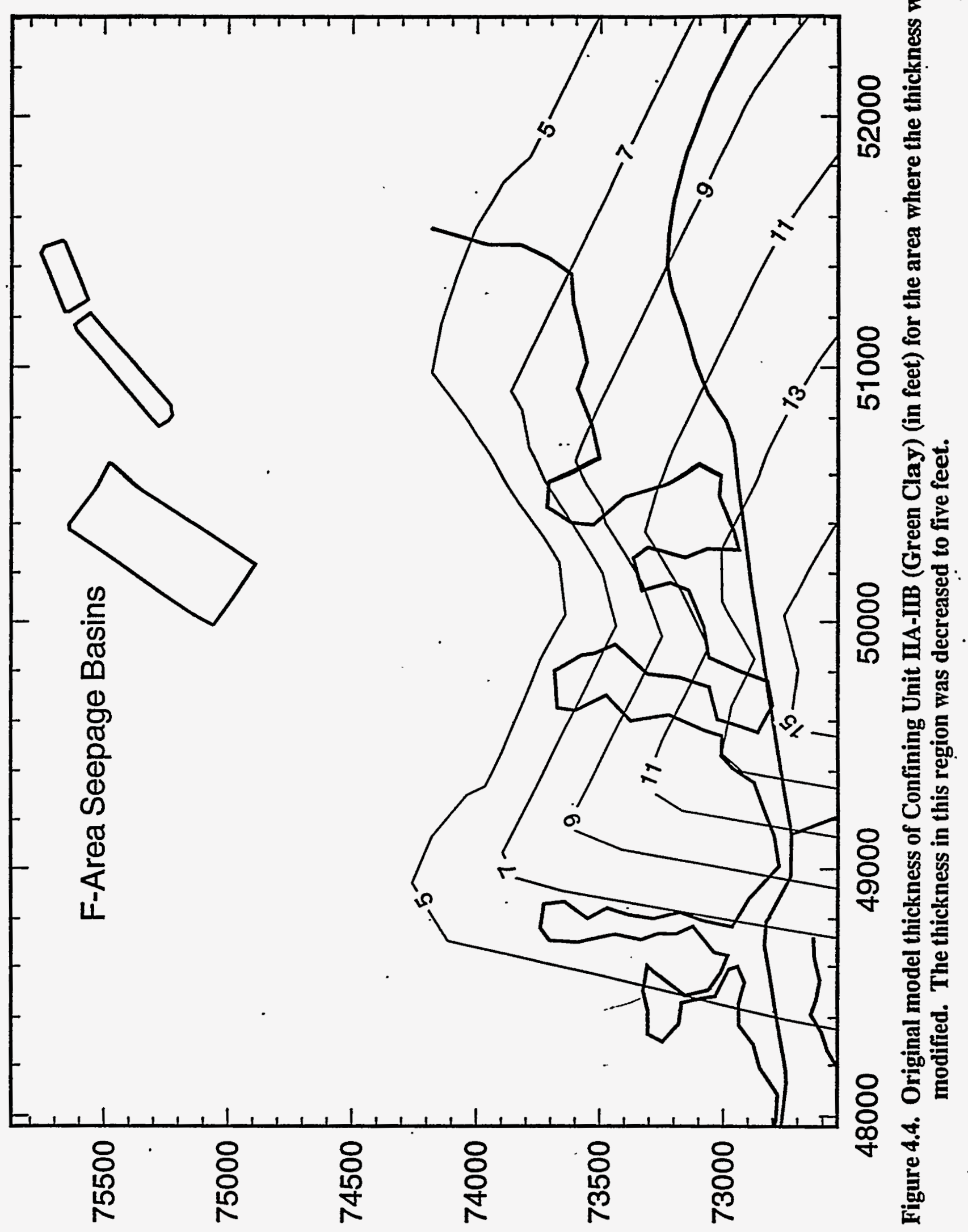




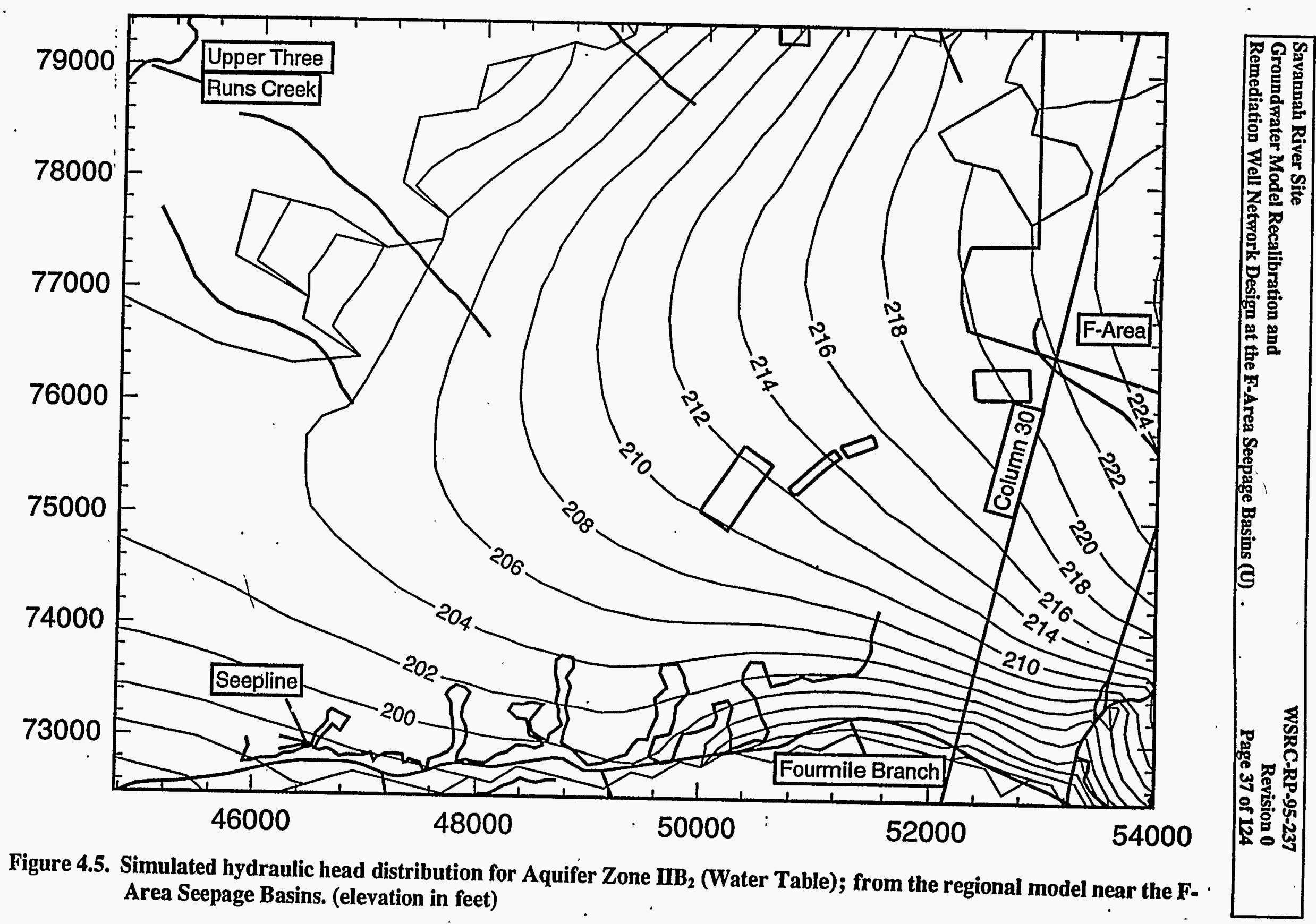


(

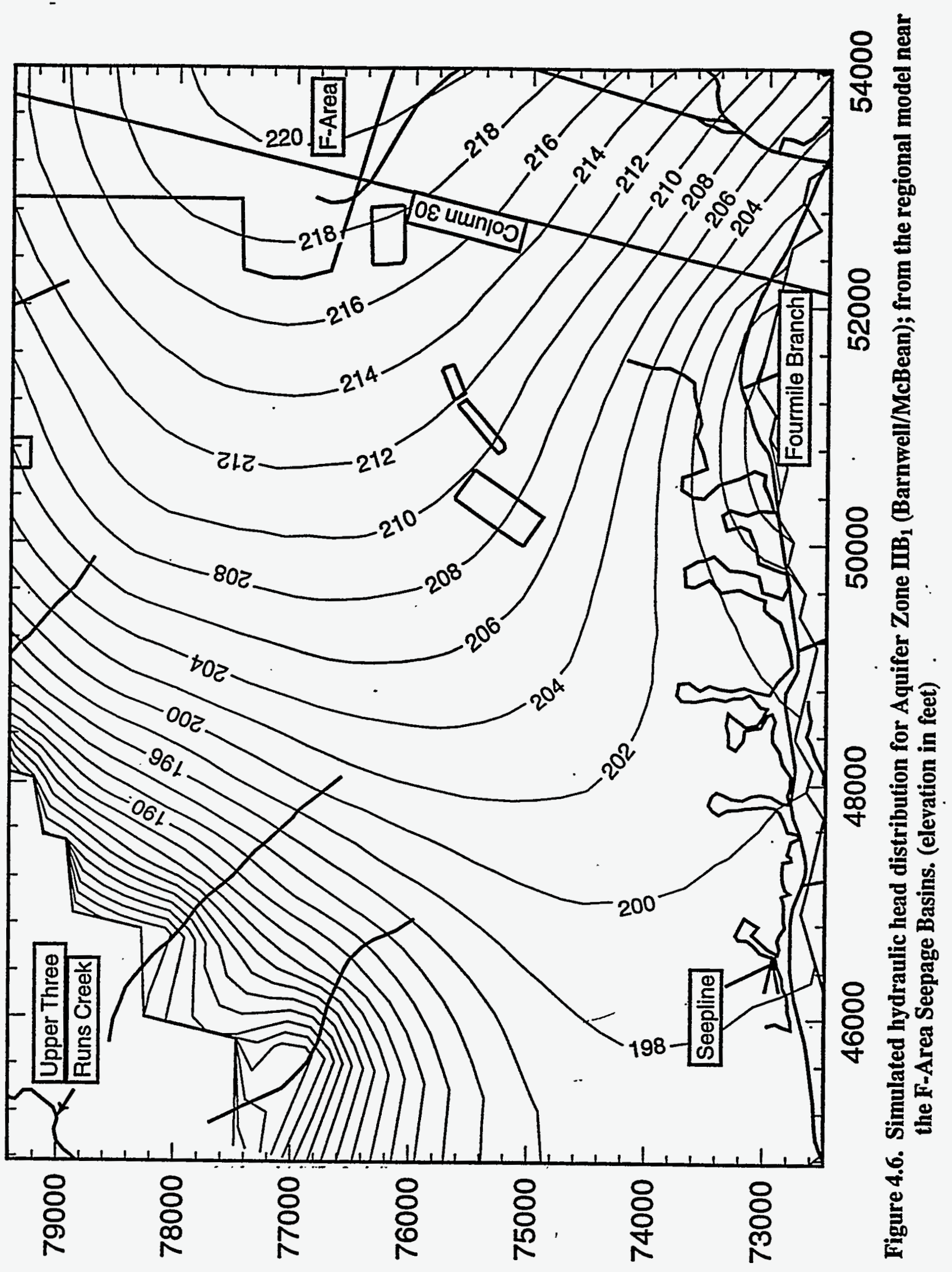



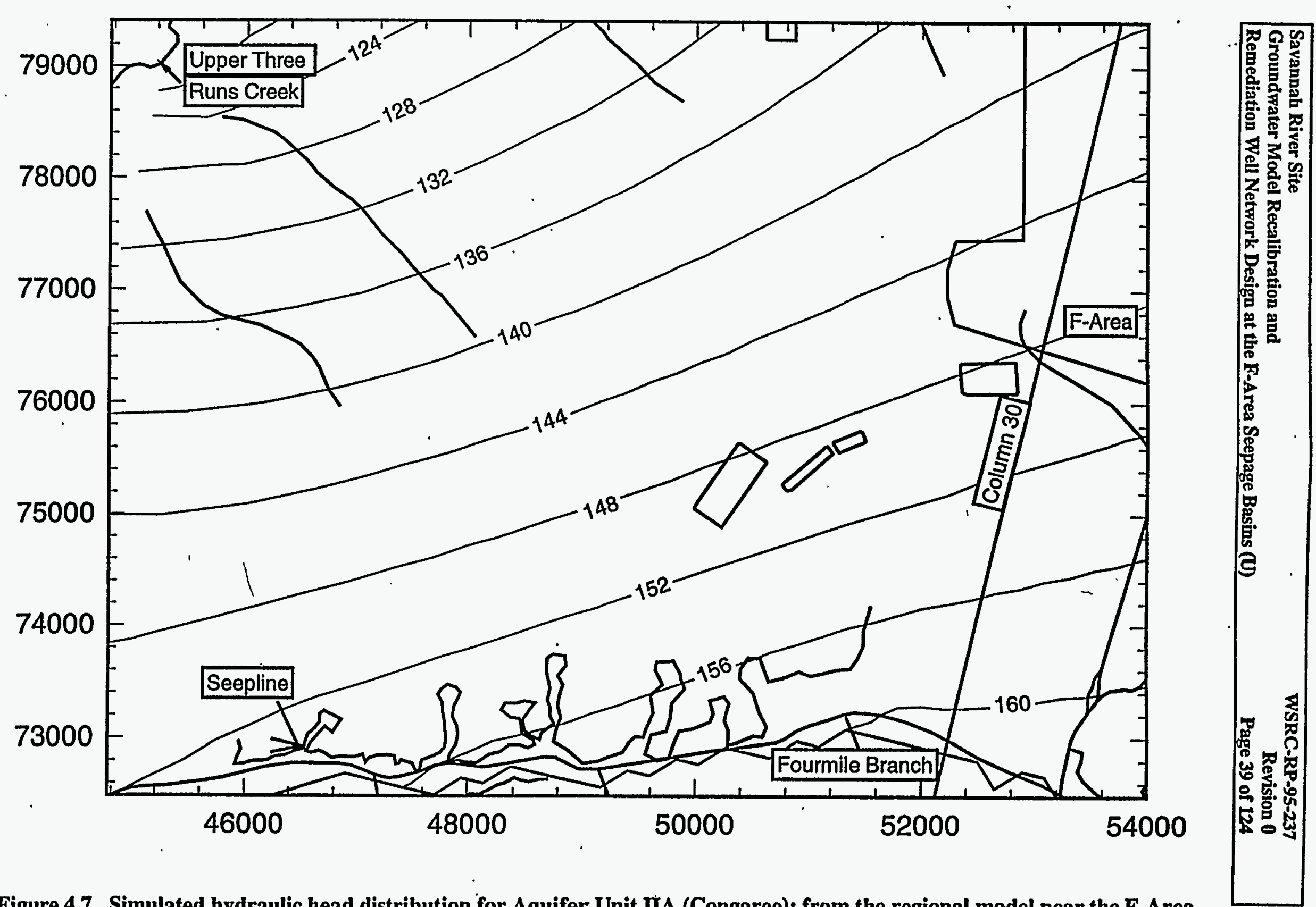

Figure 4.7. Simulated hydraulic head distribution for Aquifer Unit IIA (Congaree); from the regional model near the F-Area Seepage Basins. (elevation in feet) 
Savannah River Site

Groundwater Model Recalibration and

Remediation Well Network Design at the F-Area Seepage Basins (U)

WSRC-RP-95-237

Revision 0

Page 40 of 124

\begin{tabular}{|c|c|c|c|c|c|c|c|}
\hline & & (F-Are & Seepa & e Basins) & & & \\
\hline \multirow{2}{*}{ Well } & Column & Row & Laver & Observed & Simulated & Residual) & Residual \\
\hline & & & & Head $(\mathrm{ft})$ & Head (ft) & (ft) & Squared $\left(\mathrm{ft}^{2}\right)$ \\
\hline BRR 1D & 17 & 40 & 1 & 215.51 & 214.60 & 0.91 & 0.82 \\
\hline BRR 2D & 16 & 40 & 1 & 214.66 & 213.85 & 0.82 & 0.66 \\
\hline BRA 3D & 16 & 40 & 1 & 214.26 & 213.85 & 0.42 & 0.17 \\
\hline BRR 4D & 15 & 41 & 1 & 214.11 & 213.11 & 1.00 & 1.00 \\
\hline BRR 5D & 15 & 41 & 1 & 213.74 & 213.11 & 0.63 & 0.40 \\
\hline FCA 10A & 30 & 30 & 1 & 224.49 & 222.12 & 2.40 & 5.61 \\
\hline FCA 16A & 30 & 29 & 1 & 224.54 & 221.74 & 2.80 & 7.86 \\
\hline FSB 76 & 23 & 45 & 1 & 215.81 & 216.50 & -0.69 & 0.48 \\
\hline FSB 77 & 21 & 51 & 1 & 211.67 & 211.52 & 0.15 & 0.02 \\
\hline FSB 78D & 18 & 53 & 1 & 208.95 & 209.40 & -0.45 & 0.21 \\
\hline FSB 79D & 20 & 59 & 1 & 203.12 & 202.36 & 0.76 & 0.58 \\
\hline FSB 88D & 24 & 47 & 1 & 215.36 & 215.67 & -0.31 & 0.10 \\
\hline FSB 890 & 23 & 48 & 1 & 214.69 & 214.55 & 0.14 & 0.02 \\
\hline FSB 90D & 22 & 49 & 1 & 213.73 & 213.36 & 0.37 & 0.14 \\
\hline FSB 91D & 22 & 50 & 1 & 212.79 & 212.60 & 0.19 & 0.04 \\
\hline FSB 92D & 20 & 51 & 1 & 211.29 & 211.23 & 0.06 & 0.00 \\
\hline FSB 93D & 20 & 52 & 1 & 210.40 & 210.52 & -0.12 & 0.01 \\
\hline FSB 94DR & 18 & 53 & 1 & 209.56 & 209.40 & 0.16 & 0.02 \\
\hline FSB 95DR & 17 & 52 & 1 & 209.37 & 209.93 & -0.56 & 0.32 \\
\hline FSB 98D & 17 & 50 & 1 & 210.77 & 211.15 & -0.38 & 0.15 \\
\hline FSB 99D & 18 & 48 & 1 & 211.94 & 212.57 & -0.63 & 0.39 \\
\hline FSB104D & 15 & 59 & 1 & 205.63 & 204.57 & 1.06 & 1.13 \\
\hline FSB105DR & 16 & 51 & 1 & 209.89 & 210.35 & -0.46 & 0.22 \\
\hline FSB106D & 21 & 55 & 1 & 206.89 & $207.70^{\circ}$ & -0.81 & 0.66 \\
\hline FSB107D & 23 & 50 & 1 & 213.63 & 213.07 & 0.56 & 0.31 \\
\hline FSB108D & 21 & 45 & 1 & 215.95 & 215.53 & 0.42 & 0.17 \\
\hline FSB109D & 19 & 47 & 1 & 212.49 & 213.53 & -1.04 & 1.09 \\
\hline FSB110D & 19 & 56 & 1 & 206.17 & 206.78 & -0.61 & 0.37 \\
\hline FSB111D & 24 & 49 & 1 & 215.11 & 214.29 & 0.82 & 0.67 \\
\hline FSB112D & 12 & 57 & 1 & 206.21 & 206.03 & 0.18 & 0.03 \\
\hline FSB113D & 24 & 55 & 1 & 208.18 & 207.53 & 0.65 & 0.42 \\
\hline FSB114D & 27 & 49 & 1 & 216.53 & 215.57 & 0.96 & 0.91 \\
\hline FSB117D & 21 & 56 & 1 & 205.62 & 206.34 & -0.72 & 0.52 \\
\hline FSB118D & 24 & 52 & 1 & 212.00 & 211.57 & 0.43 & 0.18 \\
\hline FSB119D & 21 & 53 & 1 & 208.84 & 209.87 & -1.03 & 1.06 \\
\hline FSB120D & 13 & 50 & 1 & 208.45 & 209.97 & -1.52 & 2.31 \\
\hline FSB122D & 10 & 60 & 1 & 204.19 & 203.74 & 0.45 & 0.20 \\
\hline
\end{tabular}




\begin{tabular}{|c|c|c|c|c|c|c|c|}
\hline Table 4.3a. & Conti & & & & & & \\
\hline FSB123D & 26 & 52 & 1 & 212.45 & 212.31 & 0.14 & 0.02 \\
\hline FTF 12 & 28 & 38 & 1 & 226.90 & 221.65 & 5.25 & 27.54 \\
\hline FTF 13 & 30 & 41 & 1 & 222.30 & 221.88 & 0.42 & 0.18 \\
\hline FTF 16 & 29 & 40 & 1 & 222.40 & 221.73 & 0.67 & 0.45 \\
\hline FTF 17 & 29 & 40 & 1 & 221.10 & 221.73 & -0.63 & 0.40 \\
\hline FTF 18 & 29 & 39 & 1 & 221.50 & 222.04 & -0.54 & 0.29 \\
\hline FTF 19 & 28 & 39 & 1 & 221.00 & 221.43 & -0.43 & 0.19 \\
\hline FTF 20 & 27 & 40 & 1 & 220.30 & 220.51 & -0.21 & 0.04 \\
\hline FTF 21 & 27 & 40 & 1 & 221.70 & 220.51 & 1.19 & 1.41 \\
\hline FTF 22 & 27 & 41 & 1 & 220.00 & 220.19 & -0.19 & 0.04 \\
\hline FTF 23 & 28 & 41 & 1 & 220.50 & 220.73 & -0.23 & 0.05 \\
\hline FTF 24A & 28 & 38 & 1 & 220.50 & 221.65 & -1.15 & 1.33 \\
\hline FTF 25A & 29 & 38 & 1 & 221.20 & 222.26 & -1.06 & 1.12 \\
\hline FTF 26 & 29 & 38 & 1 & 220.90 & 222.26 & -1.36 & 1.84 \\
\hline FTF 27 & 28 & 38 & 1 & 220.70 & 221.65 & -0.95 & 0.91 \\
\hline FTF 5 & 30 & 39 & 1 & 222.80 & 222.50 & 0.30 & 0.09 \\
\hline FTF 6 & 30 & 38 & 1 & 219.50 & 222.83 & -3.30 & 11.10 \\
\hline FTF 7 & 30 & 38 & 1 & 221.80 & 222.83 & -1.00 & 1.06 \\
\hline FBP $1 A$ & 18 & 32 & 3 & 207.22 & 209.62 & -2.40 & 5.77 \\
\hline FSB 76C & 23 & 45 & 3 & 211.86 & 213.83 & -1.97 & 3.88 \\
\hline FSB 78C & 18 & 53 & 3 & 207.97 & 206.19 & 1.78 & 3.16 \\
\hline FSB 79C & 20 & 58 & 3 & 197.30 & 200.91 & -3.61 & 13.06 \\
\hline FSB 87C & 17 & 49 & 3 & 203.27 & 208.93 & -5.66 & 32.07 \\
\hline FSB 88C & 24 & 47 & 3 & 211.80 & 213.23 & -1.43 & 2.05 \\
\hline FSB 89C & 23 & 48 & 3 & 211.20 & 212.00 & -0.80 & 0.64 \\
\hline FSB 90C & 22 & 49 & 3 & 210.21 & 210.82 & -0.61 & 0.38 \\
\hline FSB 93C & 20 & 52 & 3 & 208.58 & 207.51 & 1.07 & 1.15 \\
\hline FSB 94C & 18 & 53 & 3 & 207.77 & 206.19 & 1.58 & 2.49 \\
\hline FSB 95CR & 17 & 52 & 3 & 206.88 & 206.85 & 0.03 & 0.00 \\
\hline FSB 97C & 17 & 51 & 3 & 207.81 & 207.61 & 0.20 & 0.04 \\
\hline FSB 98C & 17 & 50 & 3 & 208.47 & 208.31 & 0.16 & 0.02 \\
\hline FSB 99C & 18 & 49 & 3 & 209.00 & 209.35 & -0.35 & 0.12 \\
\hline FSB102C & 23 & 58 & 3 & 195.70 & 199.86 & -4.16 . & 17.33 \\
\hline FSB103C & 17 & 56 & 3 & 203.16 & 203.44 & -0.28 & 0.08 \\
\hline FSB104C & 15 & 59 & 3 & 201.73 & 201.56 & 0.17 & 0.03 \\
\hline FSB105C & 16 & 51 & 3 & 207.33 & 207.26 & 0.07 & 0.01 \\
\hline FSB106C & 21 & 55 & 3 & 201.82 & 204.29 & -2.47 & 6.10 \\
\hline FSB107C & 23 & 50 & 3 & 210.17 & 210.16 & 0.01 & 0.00 \\
\hline FSB110C & 19 & 56 & 3 & 202.26 & 203.30 & -1.04 & 1.07 \\
\hline FSB111C & 24 & 49 & 3 & 211.62 & 211.52 & 0.10 & 0.01 \\
\hline
\end{tabular}




\begin{tabular}{|l|c|c|c|c|c|c|c|}
\hline \multicolumn{2}{|l|}{ Table 4.3a. Continued } & & & & & \\
\hline & & & & & & & \\
\hline FSB112C & 12 & 57 & 3 & 202.15 & 202.78 & -0.63 & 0.39 \\
\hline FSB113C & 24 & 55 & 3 & 203.21 & 204.45 & -1.24 & 1.55 \\
\hline FSB120C & 13 & 50 & 3 & 205.43 & 206.41 & -0.98 & 0.96 \\
\hline FSB121C & 9 & 53 & 3 & 204.01 & 203.43 & 0.58 & 0.34 \\
\hline FSB122C & 10 & 60 & 3 & 200.30 & 201.38 & -1.09 & 1.18 \\
\hline FSB123C & 26 & 52 & 3 & 210.06 & 209.01 & 1.05 & 1.10 \\
\hline
\end{tabular}


Table 4.3b. Residual Values for Observation Wells Outside Modified Area.

\begin{tabular}{|c|c|c|c|c|c|c|c|c|c|}
\hline & & & & & & & & \multicolumn{2}{|c|}{ Head Difference } \\
\hline Well & Column & Row & Layer & Observed & Simulated & Residual) & Residual ! & Current - & \\
\hline & & & & Head (ft) & Head (ft) & (ft) & Squared $\left(\mathrm{ft}^{2}\right)$ & \multicolumn{2}{|c|}{ Geotrans (1993) } \\
\hline BGO 10 & 61 & 48 & 1 & 238.01 & 235.67 & 2.30 & \begin{tabular}{|l|}
5.45 \\
\end{tabular} & -0.04 & \\
\hline BGO 20 & 61 & 44 & 1 & 237.29 & 234.89 & 2.40 & 5.77 & -0.02 & \\
\hline $\mathrm{BGO} 6 \mathrm{D}$ & 56 & 35 & 1 & 230.73 & 232.18 & -1.50 & 2.11 & 0.01 & \\
\hline BGO 70 & 54 & 36 & 1 & 226.59 & 231.33 & -4.70 & 22.50 & 0.01 & \\
\hline BGO 8D & 53 & 36 & 1 & 226.74 & 230.36 & -3.60 & 13.10 & 0.02 & \\
\hline BGO 9D & 52 & 35 & 1 & 231.71 & 230.42 & 1.30 & 1.67 & 0.03 & \\
\hline BGO 11D & 48 & 36 & 1 & 230.57 & 227.61 & 3.00 & 8.78 & 0.04 & \\
\hline$B G O 12 D$ & 46 & 36 & 1 & 230.33 & 228.09 & 2.20 & 5.00 & 0.04 & \\
\hline BGO 13D & 44 & 37 & 1 & 230.04 & 227.88 & 2.20 & 4.65 & 0.02 & \\
\hline BGO 15D & 45 & 41 & 1 & 229.47 & 228.66 & 0.81 & 0.65 & -0.12 & \\
\hline BGO 16D & 47 & 41 & 1 & 230.58 & 228.48 & 2.10 & 4.42 & -0.07 & \\
\hline BGO 18D & 49 & 42 & 1 & 231.63 & 230.20 & 1.40 & 2.04 & -0.06 & \\
\hline BGO 20D & 52 & 44 & 1 & 234.75 & 233.78 & 0.97 & 0.94 & -0.06 & \\
\hline$B G 021 D$ & 54 & 45 & 1 & 234.70 & 235.19 & -0.49 & 0.24 & -0.05 & \\
\hline BGO 22D & 56 & 46 & 1 & 232.86 & 235.38 & -2.50 & 6.35 & -0.05 & \\
\hline BGO 23D & 58 & 47 & 1 & 235.46 & 235.14 & 0.32 & 0.10 & -0.04 & \\
\hline BGO 24D & 59 & 47 & 1 & 236.53 & 235.15 & 1.40 & 1.91 & -0.04 & \\
\hline BGO 26D & 40 & 41 & 1 & 227.38 & 227.59 & -0.21 & 0.05 & -0.17 & \\
\hline BGO 27D & 39 & 44 & 1 & 227.43 & 225.72 & 1.70 & 2.94 & -0.28 & \\
\hline BGO 28D & 39 & 45 & 1 & 226.34 & 225.28 & 1.10 & 1.13 & -0.30 & \\
\hline BGO 30D & 39 & 46 & 1 & 226.07 & 224.75 & 1.30 & 1.74 & -0.32 & \\
\hline BGO 31D & 41 & 47 & 1 & 227.13 & 225.04 & 2.10 & 4.37 & -0.26 & \\
\hline BGO 32D & 43 & 48 & 1 & 227.99 & 225.27 & 2.70 & 7.38 & -0.24 & \\
\hline BGO 34D & 48 & 49 & 1 & 233.39 & 230.19 & 3.20 & 10.20 & -0.14 & \\
\hline BGO 35D & 50 & 50 & 1 & 234.41 & 231.88 & 2.50 & 6.38 & -0.11 & \\
\hline BGO 36D & 52 & 50 & 1 & 236.27 & 233.59 & 2.70 & 7.19 & -0.08 & \\
\hline BGO 37D & 55 & 51 & 1 & 237.42 & 233.58 & 3.80 & 14.80 & -0.06 & \\
\hline BGO 38D & 56 & 52 & 1 & 235.21 & 232.84 & 2.40 & 5.63 & -0.06 & \\
\hline BGO 39D & 57 & 50 & 1 & 234.54 & 234.08 & 0.46 & 0.21 & -0.06 & \\
\hline$B G X-10 D$ & 63 & 35 & 1 & 226.64 & 221.00 & 5.60 & 31.80 & 0.00 & \\
\hline$B G X-12 D$ & 65 & 44 & 1 & 240.03 & 235.86 & 4.20 & 17.40 & -0.01 & \\
\hline$B G X-9 D$ & 61 & 32 & 1 & 227.42 & 219.43 & 8.00 & 63.90 & 0.02 & \\
\hline FAC 5 & 39 & 32 & 1 & 224.12 & 225.25 & -1.10 & 1.28 & 0.28 & \\
\hline FAL 1 & 32 & 33 & 1 & 218.80 & 224.59 & -5.80 & 33.50 & -0.07 & \\
\hline FAL 2 & 32 & 32 & 1 & 217.08 & 224.14 & -7.10 & 49.80 & 0.18 & \\
\hline FCA 2D & 32 & 32 & 1 & 224.39 & 224.14 & 0.25 & -0.06 & 0.18 & \\
\hline FCA 9D & 31 & 30 & 1 & 224.70 & 222.35 & 2.40 & 5.54 & 0.57 & \\
\hline FCA 16D & 31 & 29 & 1 & 224.43 & 221.90 & 2.50 & 6.39 & 0.92 & \\
\hline FCA 19D & 32 & 32 & 1 & 217.04 & 224.14 & -7.10 & 50.40 & 0.18 & \\
\hline FCB 2 & 40 & 38 & 1 & 229.18 & 228.18 & 1.00 & 0.99 & -0.07 & \\
\hline $\mathrm{FCB} 4$ & 38 & 38 & 1 & 227.82 & 227.67 & 0.15 & 0.02 & .0 .10 & \\
\hline FCB 5 & 39 & 39 & 1 & 228.10 & 227.92 & 0.18 & 0.03 & -0.11 & \\
\hline FCB 6 & 39 & 39 & 1 & 228.41 & 227.92 & 0.49 & 0.24 & -0.11 & \\
\hline FET 1D & 32 & 43 & 1 & 222.97 & 222.26 & 0.71 & 0.50 & -1.02 & \\
\hline FET 2D & 31 & 44 & 1 & 221.64 & 220.87 & 0.77 & 0.59 & -1.27 & \\
\hline FET 3D & 31 & 44 & 1 & 221.60 & 220.87 & 0.73 & 0.53 & -1.27 & \\
\hline FET 4D & 32 & 44 & 1 & 222.26 & 221.66 & 0.60 & 0.37 & -1.02 & \\
\hline
\end{tabular}




\begin{tabular}{|c|c|c|c|c|c|c|c|c|c|}
\hline able 4.3t & ntir & & & & & & & & \\
\hline FSS 1D & 36 & 46 & 1 & 223.85 & 223.16 & 0.69 & 0.47 & -0.50 & \\
\hline FSS 2D & 36 & 47 & 1 & 223.55 & 222.61 & 0.94 & 0.88 & -0.50 & \\
\hline FSS 3D & 35 & 48 & 1 & 221.40 & 221.32 & 0.08 & 0.01 & -0.59 & \\
\hline FSS 4D & 31 & 46 & 1 & 218.15 & 219.61 & -1.50 & 2.14 & -1.23 & \\
\hline FTF 15 & 31 & 40 & 1 & 223.00 & 222.83 & 0.17 & 0.03 & -1.18 & \\
\hline FTF 2 & 31 & 37 & 1 & 223.10 & 223.84 & -0.74 & 0.54 & -0.84 & \\
\hline FTF 3 & 31 & 38 & 1 & 221.50 & 223.59 & -2.10 & 4.35 & -0.97 & \\
\hline FTF 4 & 31 & 38 & 1 & 222.10 & 223.59 & -1.50 & 2.21 & -0.97 & \\
\hline HAC 1 & 76 & 53 & 1 & 270.15 & 271.32 & -1.20 & 1.36 & 0.00 & \\
\hline HAC 2 & 76 & 53 & 1 & 268.94 & 271.32 & -2.40 & 5.65 & 0.00 & \\
\hline HAC 3 & 76 & 53 & 1 & 269.98 & 271.32 & -1.30 & 1.79 & 0.00 & \\
\hline HAC 4 & 76 & 53 & 1 & 270.47 & 271.32 & -0.85 & 0.72 & 0.00 & \\
\hline HAP 1 & 85 & 55 & 1 & 272.13 & 273.92 & -1.80 & 3.20 & 0.00 & \\
\hline HAP 2 & 85 & 56 & 1 & 271.35 & 275.30 & -3.90 & 15.60 & 0.00 & \\
\hline $\mathrm{HCA} 1$ & 83 & 49 & 1 & 270.11 & 266.93 & 3.20 & 10.10 & -0.01 & . \\
\hline $\mathrm{HCA} 2$ & 83 & 51 & 1 & 271.38 & 270.87 & 0.51 & 0.26 & 0.00 & \\
\hline HCA 3 & 83 & 49 & 1 & 269.68 & 266.93 & 2.70 & 7.54 & -0.01 & \\
\hline HCA 4 & 83 & 49 & 1 & 270.09 & 266.93 & 3.20 & 9.96 & -0.01 & \\
\hline HCB 1 & 86 & 54 & 1 & 264.19 & 269.17 & -5.00 & 24.80 & 0.00 & \\
\hline HCB 2 & 86 & 54 & 1 & 269.04 & 269.17 & -0.13 & 0.02 & 0.00 & \\
\hline HCB 3 & 86 & 55 & 1 & 267.36 & 270.88 & -3.50 & 12.40 & 0.00 & \\
\hline HCB 4 & 86 & 54 & 1 & 265.76 & 269.17 & -3.40 & 11.60 & 0.00 & \\
\hline HET 1D & 72 & 55 & 1 & 269.89 & 266.29 & 3.60 & 12.90 & -0.01 & \\
\hline HET 2D & 70 . & 55 & 1 & 260.88 & 261.38 & -0.50 & 0.25 & 0.00 & \\
\hline HET 3D & 70 & 55 & 1 & 261.39 & 261.38 & 0.01 & 0.00 & 0.00 & \\
\hline HET 4D & 70 & 54 & 1 & 261.21 & 261.35 & -0.14 & 0.02 & -0.01 & \\
\hline HA3 11 & 71 & 58 & 1 & 262.66 & 264.07 & -1.40 & 1.99 & -0.01 & \\
\hline HR3 13 & 70 & 57 & 1 & 261.56 & 261.16 & 0.40 & 0.16 & -0.01 & \\
\hline HRB 11 & 67 & 56 & 1 & 248.04 & 249.44 & -1.40 & 1.95 & 0.00 & \\
\hline HR8 12 & 66 & 57 & 1 & 240.69 & 243.80 & -3.10 & 9.66 & 0.00 & \\
\hline HR8 13 & 67 & 58 & 1 & 239.78 & 249.05 & -9.30 & 86.00 & -0.01 & \\
\hline HSB 65 & 61 & 55 & 1 & 232.65 & 231.96 & 0.69 & 0.48 & -0.03 & \\
\hline HSB 65C & 61 & 55 & 1 & 232.92 & 231.96 & 0.96 & 0.93 & -0.03 & \\
\hline HSB 66 & 54 & 57 & 1 & 226.09 & 227.61 & -1.50 & 2.31 & -0.06 & \\
\hline HSB 67 & 62 & 60 & 1 & 224.79 & 225.59 & -0.80 & 0.64 & -0.01 & \\
\hline HSB 68 & 55 & 61 & 1 & 223.14 & 221.31 & 1.80 & 3.35 & -0.03 & \\
\hline HSB 69 & 53 & 62 & 1 & 220.36 & 216.78 & 3.60 & 12.80 & -0.02 & \\
\hline HSB 70 & 48 & 57 & 1 & 228.73 & 224.78 & 3.90 & 15.60 & -0.12 & \\
\hline HSB 71 & 45 & 56 & 1 & 228.16 & 222.34 & 5.80 & 33.90 & -0.18 & \\
\hline HSB 83D & 63 & 59 & 1 & 226.26 & 228.44 & -2.20 & 4.74 & -0.01 & \\
\hline HSB 84D & 52 & 62 & 1 & 219.90 & 213.11 & 6.80 & 46.10 & -0.01 & \\
\hline HSB 85C & 62 & 48 & 1 & 238.06 & 236.82 & 1.20 & 1.55 & -0.03 & \\
\hline HSB 86D & 49 & 57 & 1 & 226.18 & 225.89 & 0.29 & 0.09 & -0.09 & . \\
\hline HSB100D & 63 & $56^{\prime}$ & 1 & 234.23 & 232.98 & 1.30 & 1.57 & -0.02 & \\
\hline HSB101D & 63 & 57 & 1 & 231.44 & 232.08 & -0.64 & 0.42 & -0.03 & \\
\hline HSB102D & 62 & 57 & 1 & 228.17 & 230.89 & -2.70 & 7.39 & -0.02 & \\
\hline HSB103D & 62 & 59 & 1 & 226.63 & 228.12 & -1.50 & 2.21 & -0.01 & \\
\hline HSB104D & 61 & 61 & 1 & 226.18 & 223.13 & 3.00 & 9.28 & -0.02 & \\
\hline HSB105D & 60 & 60 & 1 & 226.66 & 226.41 & 0.25 & 0.06 & -0.02 & \\
\hline
\end{tabular}




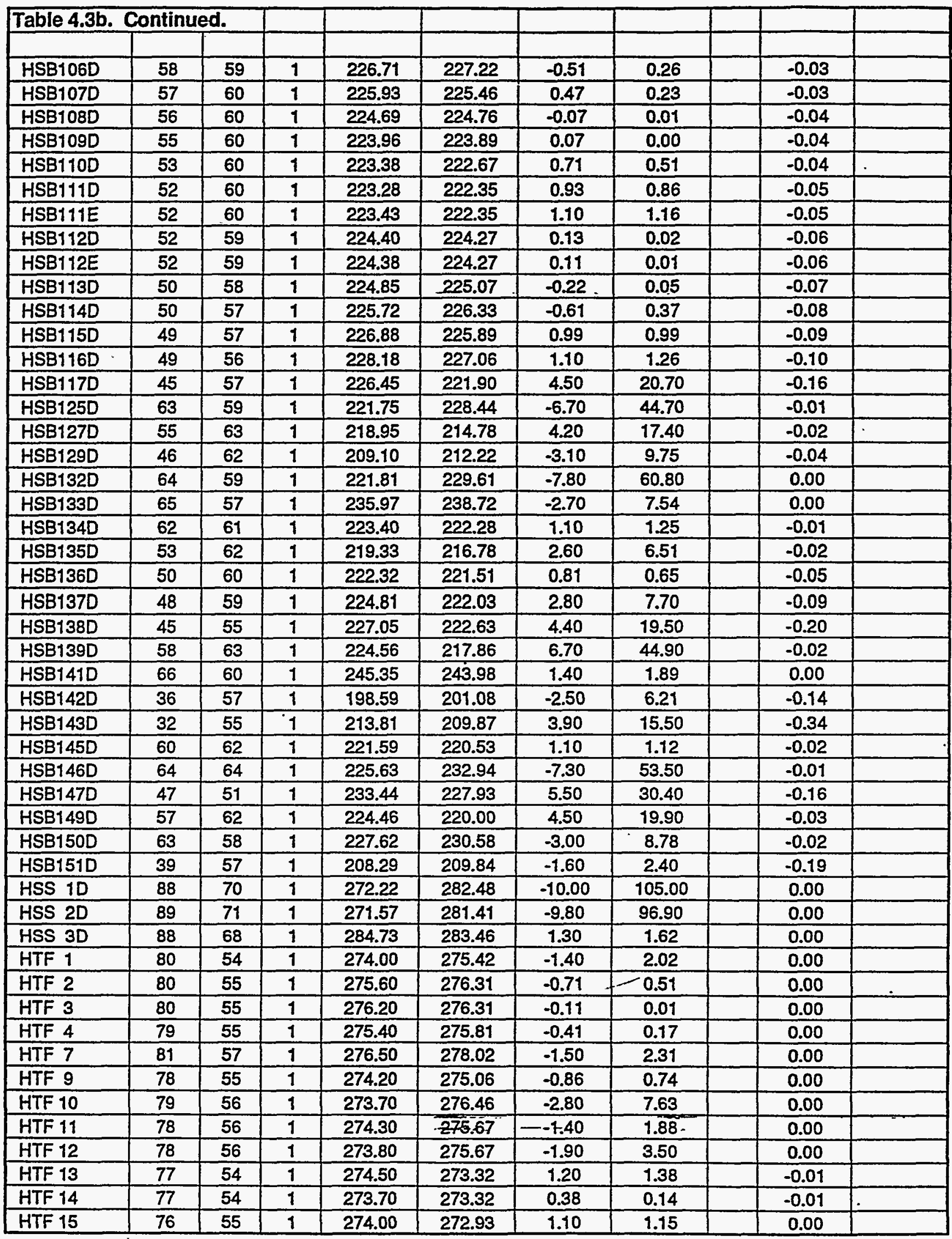


Savannah River Site

Groundwater Model Recalibration and

Remediation Well Network Design at the F-Area Seepage Basins (U)

Page 46 of 124

\begin{tabular}{|c|c|c|c|c|c|c|c|c|c|}
\hline able $4.3 b$ & ntin & & & & & & & & \\
\hline & 79 & & & & & & & & \\
\hline HTF 17 & 74 & 52 & 1 & 270.50 & 272.56 & -2.10 & 4.24 & 0.00 & \\
\hline HTF 18 & $\frac{74}{76}$ & 51 & 1 & 263.20 & 266.77 & -3.60 & 12.80 & -0.01 & \\
\hline HTF 19 & 76 & 55 & 1 & 272.50 & 272.93 & -0.43 & 0.18 & 0.00 & \\
\hline HTF 20 & 75 & 55 & 1 & 270.20 & 271.60 & -1.40 & 1.96 & 0.00 & \\
\hline HTF 21 & 75 & 54 & 1 & 269.60 & 270.97 & -1.40 & 1.88 & -0.01 & \\
\hline HTF 22 & 76 & 54 & 1 & 270.20 & 272.23 & -2.00 & 4.10 & 0.00 & \\
\hline & 82 & 55 & 1 & 276.50 & 276.65 & -0.15 & 0.02 & 0.00 & \\
\hline & 83 & 55 & 1 & 275.50 & 276.36 & -0.86 & 0.75 & -0.01 & \\
\hline & 83 & 55 & 1 & 274.80 & 276.36 & -1.60 & 2.44 & -0.01 & \\
\hline HTF 25 & 84 & 56 & 1 & 274.60 & 276.72 & -2.10 & 4.51 & 0.00 & \\
\hline HTF 26 & 83 & 57 & 1 & 275.10 & 278.32 & -3.20 & 10.40 & 0.00 & \\
\hline HTF 27 & 83 & 57 & 1 & 277.10 & 278.32 & -1.20 & 1.49 & 0.00 & \\
\hline HTF 28 & 82 & 57 & 1 & 276.80 & 278.30 & -1.50 & 2.26 & 0.00 & \\
\hline HTF 29 & 82 & 56 & 1 & 277.20 & 277.53 & -0.33 & 0.11 & 0.00 & \\
\hline HTF 31 & 83 & 58 & 1 & 276.80 & 279.17 & -2.40 & 5.60 & 0.00 & \\
\hline HTF 32 & 84 & 58 & 1 & 275.40 & 278.91 & -3.50 & 12.30 & 0.00 & \\
\hline NBG 1 & 31 & 27 & 1 & 223.54 & 220.79 & 2.70 & 7.55 & 1.66 & \\
\hline NBG 2 & 32 & 28 & 1 & 223.93 & 221.75 & 2.20 & 4.74 & 1.07 & \\
\hline NBG 3 & 33 & 28 & 1 & 217.53 & 222.01 & -4.50 & 20.10 & 0.97 & \\
\hline SBG 1 & 84 & 38 & 1 & 238.76 & 236.34 & 2.40 & 5.87 & 0.00 & \\
\hline SBG 2 & 86 & 37 & 1 & 237.46 & 234.58 & 2.90 & 8.32 & 0.00 & \\
\hline SBG 3 & 87 & 41 & 1 & 237.47 & 236.27 & 1.20 & 1.45 & 0.00 & \\
\hline SBG 4 & 87 & 48 & 1 & 241.35 & 245.10 & -3.70 & 14.10 & 0.00 & \\
\hline SBG 5 & 87 & 49 & 1 & 249.91 & 247.27 & 2.60 & 6.99 & 0.00 & \\
\hline SBG 6 & 85 & 43 & 1 & 244.72 & 242.92 & 1.80 & 3.25 & 0.00 & \\
\hline SCA 2 & 86 & 41 & 1 & 241.63 & 238.65 & 3.00 & 8.89 & 0.00 & \\
\hline SCA 3 & 86 & 41 & 1 & 240.10 & 238.65 & 1.50 & 2.11 & 0.00 & \\
\hline SCA 4 & 86 & 41 & 1 & 240.42 & 238.65 & 1.80 & 3.14 & 0.00 & \\
\hline SCA 5 & 86 & 40 & 1 & 239.75 & 237.38 & 2.40 & 5.59 & -0.01 & \\
\hline SCA 6 & 86 & 42 & 1 & 240.47 & 239.79 & 0.68 & 0.46 & -0.01 & \\
\hline SLP 1 & 86 & 46 & 1 & 245.23 & 246.80 & -1.60 & 2.46 & 0.00 & \\
\hline SLP 2 & 86 & 46 & 1 & 244.86 & 246.80 & -1.90 & 3.76 & 0.00 & \\
\hline ZBG 1 & 87 & 27 & 1 & 234.45 & 226.58 & 7.90 & 61.90 & 0.00 & \\
\hline ZDT 1 & 88 & 51 & 1 & 240.02 & 237.97 & 2.10 & 4.22 & 0.00 & \\
\hline ZDT 2 & 88 & 51 & 1 & 241.59 & 237.97 & 3.60 & 13.10 & 0.00 & \\
\hline BGO $6 C$ & 56 & 35 & 3 & 220.41 & 220.00 & 0.41 & 0.17 & 0.02 & \\
\hline BGO $8 \mathrm{C}$ & 53 & 36 & 3 & 218.50 & 221.99 & -3.40 & 11.50 & 0.02 & \\
\hline BGO 10C & 49 & 35 & 3 & 220.44 & 222.07 & -1.60 & 2.67 & 0.05 & \\
\hline $8 G 014 C$ & 44 & 39 & 3 & 222.91 & 223.51 & -0.60 & 0.35 & 0.00 & \\
\hline BGO 27C & 39 & 44 & 3 & 220.35 & 221.68 & -1.30 & 1.76 & -0.15 & \\
\hline BGO $30 \mathrm{C}$ & 39 & 46 & 3 & 219.31 & 220.85 & -1.50 & 2.39 & -0.22 & \\
\hline BGO 31C & 41 & 47 & 3 & 226.04 & 221.36 & 4.70 & $21.90^{\circ}$ & -0.22 & \\
\hline BGO 33C & 46 & 48 & 3 & 225.54 & 223.61 & 1.90 & 3.72 & -0.16 & \\
\hline BGO 35C & 50 & 50 & 3 & 228.95 & 225.17 & 3.80 & 14.30 & -0.11 & \\
\hline$B G X-12 C$ & 65 & 44 & 3 & 235.04 & 225.87 & 9.20 & 84.10 & -0.01 & \\
\hline$B G X-2 B$ & 55 & 32 & 3 & 213.50 & 217.26 & -3.80 & 14.10 & 0.04 & \\
\hline$B G X-2 D$ & 55 & 32 & 3 & 216.03 & 217.26 & -1.20 & 1.51 & 0.04 & \\
\hline$B G X-4 C$ & 49 & 30 & 3 & 215.56 & 217.63 & -2.10 & 4.30 & 0.11 & \\
\hline$B G X-4 D$ & 49 & 30 & 3 & 216.56 & 217.63 & -1.10 & 1.16 & 0.11 & \\
\hline
\end{tabular}




\begin{tabular}{|c|c|c|c|c|c|c|c|c|c|}
\hline Table 4.3b. & ntin & & & - & & & & & \\
\hline RGX-5n & 10 & דר & 0 & ת90 & & & & & \\
\hline FNB 1 & $\frac{45}{32}$ & 27 & $\frac{3}{3}$ & 210.80 & 213.75 & -3.00 & 8.71 & 0.13 & \\
\hline FNB 2 & 32 & $2<$ & & 277.00 & 206.93 & 4.10 & 16.60 & 1.77 & \\
\hline & & 27 & 3 & 207.48 & 205.14 & 2.30 & 5.49 & 1.82 & \\
\hline FIVD 3 & 37 & 20 & 3 & 209.50 & 203.39 & 6.10 & 37.30 & 2.09 & \\
\hline HMD-1DC & 47 & 26 & 3 & 210.83 & 212.48 & -1.60 & 2.72 & 0.17 & \\
\hline HMD-2DC & 47 & 21 & 3 & 202.98 & 202.20 & 0.78 & 0.62 & 0.15 & \\
\hline HMD-3DC & 50 & 21 & 3 & 202.50 & 201.28 & 1.20 & 1.50 & 0.10 & \\
\hline HMD-4DC & 52 & 23 & 3 & 202.45 & 203.65 & -1.20 & 1.44 & 0.08 & \\
\hline HSB 65B & 61 & 55 & 3 & 224.93 & 227.47 & -2.50 & 6.44 & -0.04 & \\
\hline HSB 68B & 55 & 61 & 3 & 217.95 & 218.10 & -0.15 & 0.02 & -0.06 & \\
\hline HSB $68 \mathrm{C}$ & 55 & 61 & 3 & 218.78 & 218.10 & 0.68 & 0.46 & -0.06 & \\
\hline HSB 70C & 48 & 57 & 3 & 226.15 & 223.41 & 2.70 & 7.51 & -0.11 & \\
\hline HSB 71C & 45 & 57 & 3 & 225.98 & 221.58 & 4.40 & 19.40 & -0.16 & \\
\hline HSB 83B & 63 & 59 & 3 & 223.68 & 225.16 & -1.50 & 2.18 & -0.02 & \\
\hline HSB $83 C$ & 63 & 59 & 3 & 225.41 & 225.16 & 0.25 & 0.06 & -0.02 & \\
\hline HSB 84B & 52 & 61 & 3 & 211.60 & 215.85 & -4.20 & 18.10 & -0.06 & \\
\hline HSB 84C & 52 & 61 & 3 & 214.67 & 215.85 & -1.20 & 1.39 & -0.06 & \\
\hline HSB 85B & 62 & 48 & 3 & 233.07 & 229.21 & 3.90 & 14.90 & -0.04 & \\
\hline HSB 86B & 49 & 57 & 3 & 223.55 & 220.17 & 3.40 & 11.40 & -0.10 & \\
\hline HSB $86 C$ & 49 & 57 & 3 & 226.15 . & 220.17 & 6.00 & 35.80 & -0.10 & \\
\hline HSB100C & 64 & 56 & 3 & 227.11 & 227.99 & -0.88 & 0.78 & -0.03 & \\
\hline HSB101C & 63 & 57 & 3 & 225.96 & 226.97 & -1.00 & 1.02 & -0.03 & \\
\hline HSB102C & 62 & 57 & 3 & 225.19 & 226.56 & -1.40 & 1.87 & -0.03 & \\
\hline HSB103C & 62 & 59 & 3 & 224.36 & 224.62 & -0.26 & 0.07 & -0.03 & $\cdot$ \\
\hline HSB104C & 61 & 61 & 3 & 221.37 & 221.95 & -0.58 & 0.34 & -0.03 & \\
\hline HSB105C & 60 & 60 & 3 & 220.61 & 222.44 & -1.80 & 3.36 & -0.04 & \\
\hline $\mathrm{HSB106C}$ & 58 & 59 & 3 & 222.50 & 222.26 & 0.24 & 0.06 & -0.04 & \\
\hline HSB107C & 57 & 60 & 3 & 220.21 & 220.49 & -0.28 & 0.08 & -0.05 & \\
\hline HSB108C & 56 & 60 & 3 & 219.27 & 219.91 & -0.64 & 0.41 & -0.05 & \\
\hline HSB109C & 55 & 60 & 3 & 219.78 & 219.31 & 0.47 & 0.22 & -0.06 & \\
\hline HSB110C & 54 & 60 & 3 & 220.20 & 218.67 & 1.50 & 2.34 & -0.06 & \\
\hline HSB111C & 52 & 60 & 3 & 221.43 & 217.28 & 4.10 & 17.20 & -0.07 & \\
\hline HSB112C & 52 & 59 & 3 & 223.10 & 218.69 & 4.40 & 19.50 & -0.07 & \\
\hline HSB113C & 50 & 58 & 3 & 223.75 & 219.00 & 4.80 & 22.60 & -0.09 & \\
\hline $\mathrm{HSB114C}$ & 50 & 58 & 3 & 225.64 & 219.00 & 6.60 & 44.20 & -0.09 & \\
\hline HSB1 15C & 49 & 57 & 3 & 226.72 & 220.17 & 6.60 & 42.90 & -0.10 & \\
\hline HSB117C & 45 & 57 & 3 & 224.45 & 221.58 & 2.90 & 8.25 & -0.16 & \\
\hline HSB125C & 63 & 59 & 3 & 224.40 & 225.16 & -0.76 & -0.57 & -0.02 & \\
\hline HSB127C & 55 & 63 & 3 & 210.83 & 215.33 & -4.50 & 20.30 & -0.05 & \\
\hline HSB129C & 46 & 62 & 3 & 206.44 & 207.89 & -1.50 & 2.10 & -0.11 & \\
\hline HSB133C & 65 & 57 & 3 & 231.12 & 227.63 & 3.50 & 12.20 & -0.03 & \\
\hline HSB134C & 62 & 61 & 3 & 220.94 & 222.54 & -1.60 & 2.57 & -0.03 & \\
\hline HSB135C & 53 & 62 & 3 & 207.19 & 215.20 & -8.00 & 64.20 & -0.06 & \\
\hline HSB136C & 50 & 60 & 3 & 218.93 & 215.65 & 3.30 & 10.70 & -0.08 & \\
\hline HSB137C & 48 & 59 & 3 & 222.61 & 214.90 & 7.70 & 59.50 & -0.09 & \\
\hline HSB139C & 58 & 63 & 3 & 215.26 & 217.40 & -2.10 & 4.57 & -0.03 & \\
\hline HSB141C & 66 & 60 & 3 & 229.95 & 225.52 & 4.40 & 19.60 & -0.02 & \\
\hline HSB142C & 37 & 57 & 3 & 198.96 & 208.49 & -9.50 & 90.90 & -0.60 & \\
\hline HSB143C & 32 & 55 & 3 & 209.70 & 208.21 & 1.50 & 2.22 & -1.03 & \\
\hline
\end{tabular}


Savannah River Site

Groundwater Model Recalibration and

Remediation Well Network Design at the F-Area Seepage Basins (U)
WSRC-RP-95-237

Revision 0

Page 48 of 124

\begin{tabular}{|c|c|c|c|c|c|c|c|c|c|}
\hline Table 4.3b. & ontin & & & & & & - & & \\
\hline HSB145C & 60 & 62 & 3 & 214.09 & 220.12 & -6.00 & 36.30 & -0.03 & \\
\hline HSB146C & 64 & 65 & 3 & 210.43 & 219.65 & -9.20 & 85.10 & -0.02 & \\
\hline HSB151C & 39 & 57 & 3 & 208.92 & 210.05 & -1.10 & 1.28 & -0.44 & \\
\hline HSB152C & 42 & 62 & 3 & 199.06 & 205.01 & -6.00 & 35.50 & -0.20 & \\
\hline YSC $1 \mathrm{C}$ & 87 & 18 & 3 & 223.30 & 212.29 & 11.00 & 121.00 & 0.00 & \\
\hline YSC $4 \mathrm{C}$ & 87 & 24 & 3 & 226.95 & 218.70 & 8.20 & 68.00 & 0.00 & \\
\hline BGO $6 A$ & 56 & 35 & 5 & 159.49 & 153.22 & 6.30 & 39.30 & -0.04 & \\
\hline$B G O 14 A$ & 44 & 39 & 5 & 158.81 & 151.78 & 7.00 & 49.50 & -0.09 & \\
\hline BGO 16A & 47 & 41 & 5 . & 161.44 & 154.04 & 7.40 & 54.80 & -0.07 & \\
\hline BGO 18A & 49 & 42 & 5 & 161.48 & 155.33 & 6.20 & 37.80 & -0.06 & \\
\hline BGO 25A & 44 & 40 & 5 & 161.30 & 152.40 & 8.90 & 79.30 & -0.08 & \\
\hline BGO 26A & 40 & 41 & 5 & 160.82 & 151.62 & 9.20 & 84.60 & -0.11 & \\
\hline BGO 29A & 37 & 45 & 5 & 159.53 & 153.05 & 6.50 & 42.00 & -0.12 & \\
\hline$B G X-4 A$ & 49 & 30 & 5 & 155.11 & 147.83 & 7.30 & 53.00 & -0.07 & \\
\hline FSB $76 A$ & 23 & 45 & 5 & 155.41 & 147.18 & 8.20 & 67.80 & -0.24 & \\
\hline FSB 76B & 23 & 45 & 5 & 151.67 & 147.18 & 4.50 & 20.20 & -0.24 & \\
\hline FSB 78A &. .18 & 53 & 5 & 156.06 & 150.65 & 5.40 & 29.30 & -0.18 & \\
\hline FSB 78B & 18 & 53 & 5 & 154.41 & 150.65 & 3.80 & 14.20 & -0.18 & \\
\hline FSB 79B & 20 & 59 & 5 & 157.96 & 156.23 & 1.70 & 3.01 & -0.06 & \\
\hline FSB 87A & 17 & 49 & 5 & 153.96 & 147.12 & 6.80 & 46.80 & -0.24 & \\
\hline FSB 87B & 17 & 49 & 5 & 150.80 & 147.12 & 3.70 & 13.60 & -0.24 & \\
\hline FSB 96AR & 16 & 53 & 5 & 152.95 & 149.67 & 3.30 & 10.80 & -0.19 & \\
\hline FSB 97A & 17 & 51 & 5 & 152.19 & 148.63 & 3.60 & 12.70 & -0.22 & \\
\hline FSB 98A & 17 & 50 & 5 & 151.37 & 147.87 & 3.50 & 12.20 & -0.23 & \\
\hline FSB 99A & 18 & 49 & 5 & 150.78 & 147.62 & 3.20 & 9.99 & -0.24 & \\
\hline FSB100A & 21 & 49 & 5 & 151.65 & 149.09 & 2.60 & 6.56 & -0.22 & \\
\hline FSB101A & 22 & 47 & 5 & 151.75 & 148.11 & 3.60 & 13.20 & -0.24 & \\
\hline FSB112A & 12 & 57 & 5 & 154.34 & 150.82 & 3.50 & 12.40 & -0.14 & \\
\hline FSB113A & 23 & 55 & 5 & 157.99 & 154.57 & 3.40 & 11.70 & -0.12 & \\
\hline FSB114A & 27 & 48 & 5 & 155.32 & 151.11 & 4.20 & 17.70 & -0.19 & \\
\hline FSB120A & 13 & 51 & 5 & 148.35 & 146.63 & 1.70 & 2.95 & -0.23 & \\
\hline HSB 65A & 61 & 55 & 5 & 170.99 & 167.29 & 3.70 & 13.70 & -0.02 & \\
\hline HSB $68 \mathrm{~A}$ & 55 & 61 & 5 & 171.43 & 169.18 & 2.20 & 5.06 & -0.01 & \\
\hline HSB $69 \mathrm{~A}$ & 53 & 62 & 5 & 171.73 & 169.10 & 2.60 & 6.93 & -0.01 & \\
\hline HSB $83 \mathrm{~A}$ & 63 & 59 & 5 & 172.92 & 170.35 & 2.60 & 6.61 & -0.01 & \\
\hline HSB 84A & 52 & 62 & 5 & 171.48 & 168.71 & 2.80 & 7.66 & -0.01 & \\
\hline HSB $85 A$ & 62 & 48 & 5 & 168.62 & 163.34 & 5.30 & 27.90 & -0.02 & \\
\hline HSB 86A & 49 & 57 & 5 & 168.19 & 164.55 & 3.60 & 13.20 & -0.03 & \\
\hline HSB117A & 45 & 57 & 5 & 165.96 & 163.17 & 2.80 & 7.77 & -0.03 & \\
\hline HSB118A & 48 & 57 & 5 & 167.29 & 164.20 & 3.10 & 9.53 & -0.03 & \\
\hline HSB119A & 49 & 55 & 5 & 166.69 & 163.35 & 3.30 & 11.20 & -0.03 & \\
\hline HSB120A & 50 & 53 & 5 & 165.92 & 162.48 & 3.40 & 11.90 & -0.03 & \\
\hline HSB121A & 57 & 58 & 5 & 171.24 & 167.92 & 3.30 & 11.00 & -0.02 & \\
\hline HSB122A & 58 & 57 & 5 & 171.08 & 167.61 & 3.50 & 12.00 & -0.02 & \\
\hline HSB123A & 60 & 57 & 5 & 171.33 & 168.23 & 3.10 & 9.62 & -0.02 & \\
\hline HSB139A & 58 & 63 & 5 & 173.18 & 171.53 & 1.70 & 2.72 & -0.01 & \\
\hline HSB141A & 66 & 60 & 5 & 174.29 & 171.77 & 2.50 & 6.34 & -0.01 & \\
\hline HSB144A & 51 & 60 & 5 & 170.25 & 167.09 & 3.20 & 9.99 & -0.02 & \\
\hline YSC 2A & 87 & 18 & 5 & 162.88 & 158.55 & 4.30 & 18.80 & 0.00 & \\
\hline YSC $5 \mathrm{~A}$ & 89 & 36 & 5 & 178.95 & 171.80 & 7.20 & 51.20 & 0.00 & \\
\hline
\end{tabular}



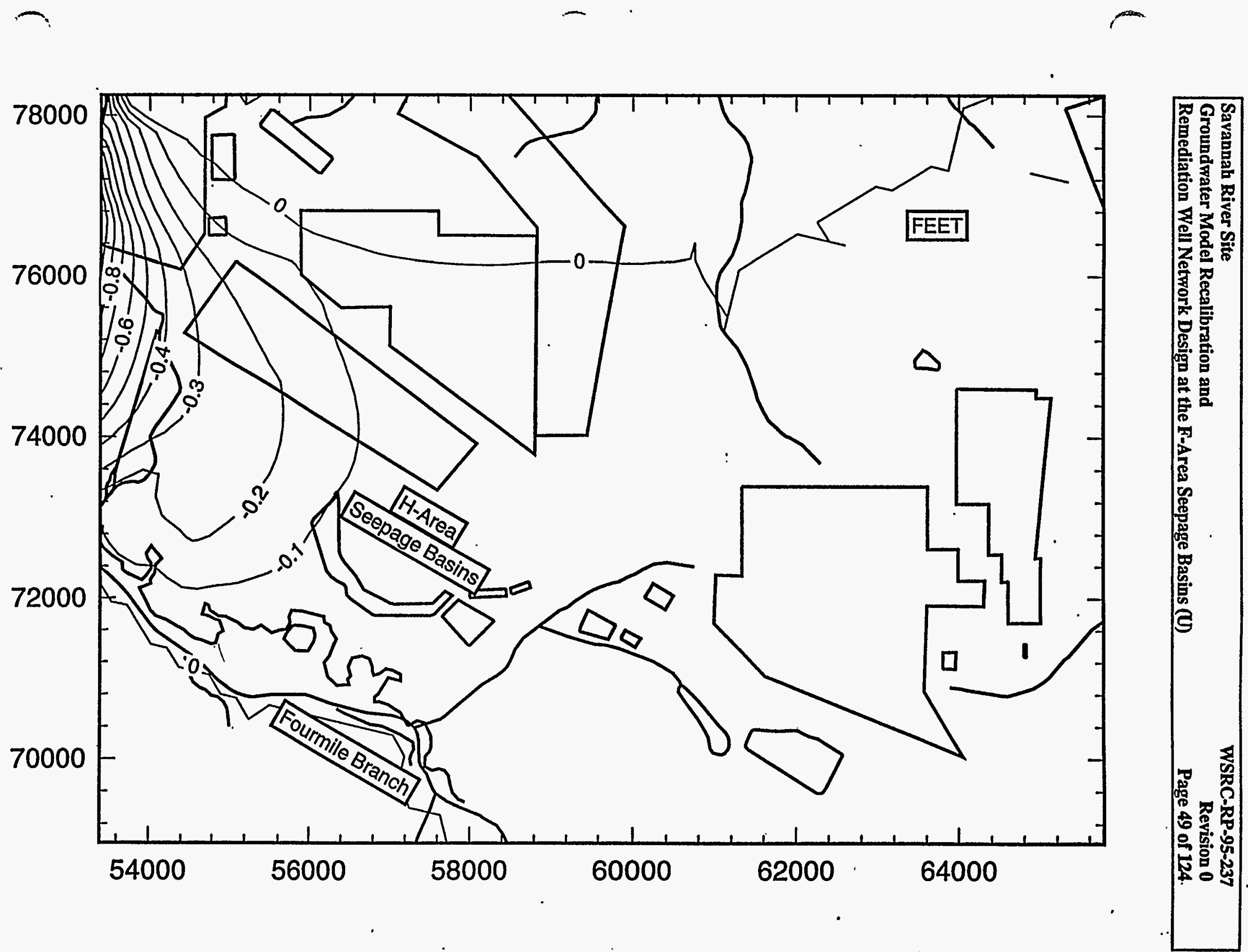

Figure 4.8. Difference in hydraulic head values between the current modeling effort and the model in GeoTrans (1993) for Aquifer Zone $\mathbf{I I B}_{2}$ (Water Table) near the H-Area Seepage Basins. (in feet) 

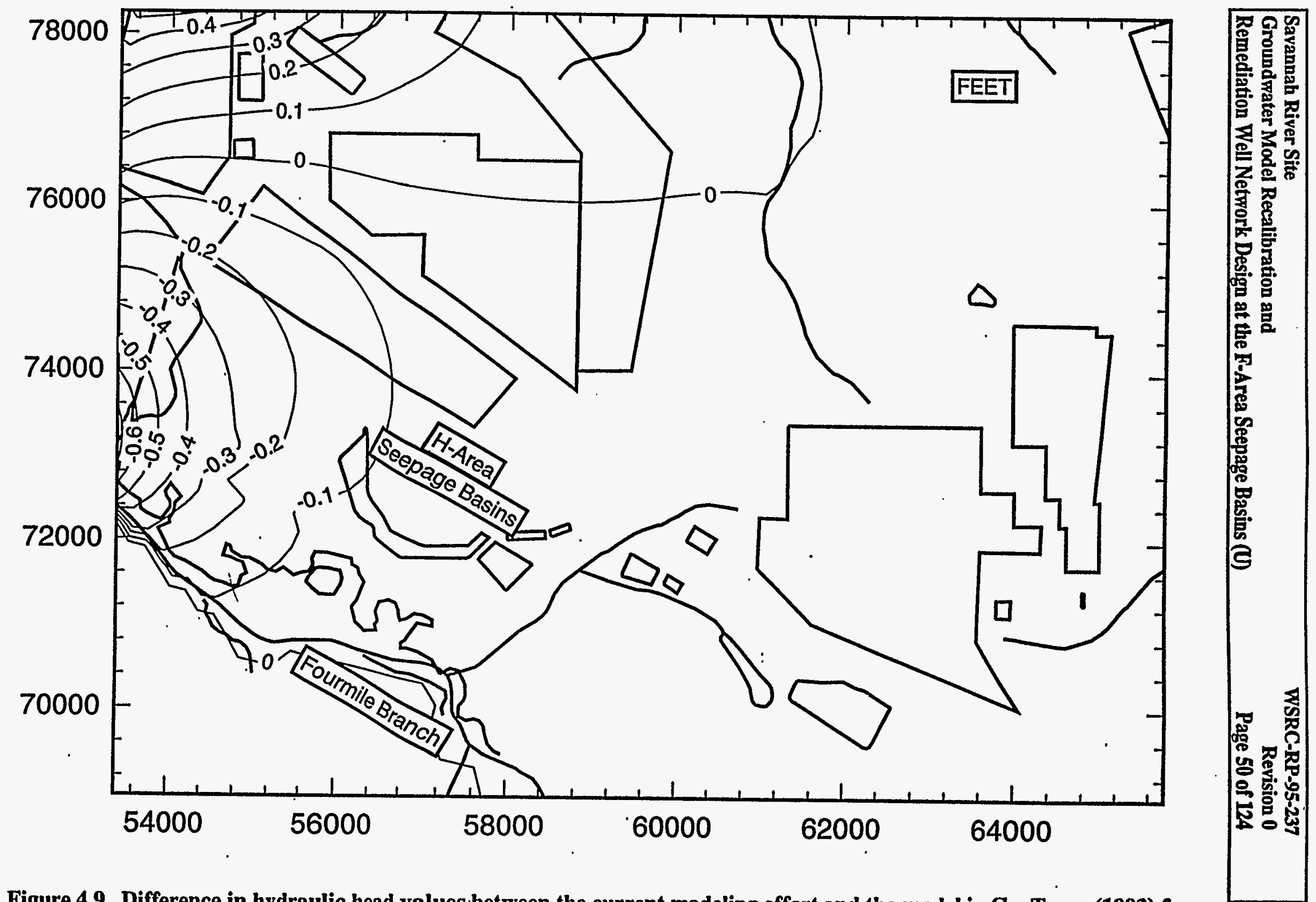

Figure 4.9. Difference in hydraulic head values between the current modeling effort and the model in GeoTrans (1993) for Aquifer Zone $\mathrm{IIB}_{1}$ (Barnwell/McBean) near the H-Area Seepage Basins. (in feet) 


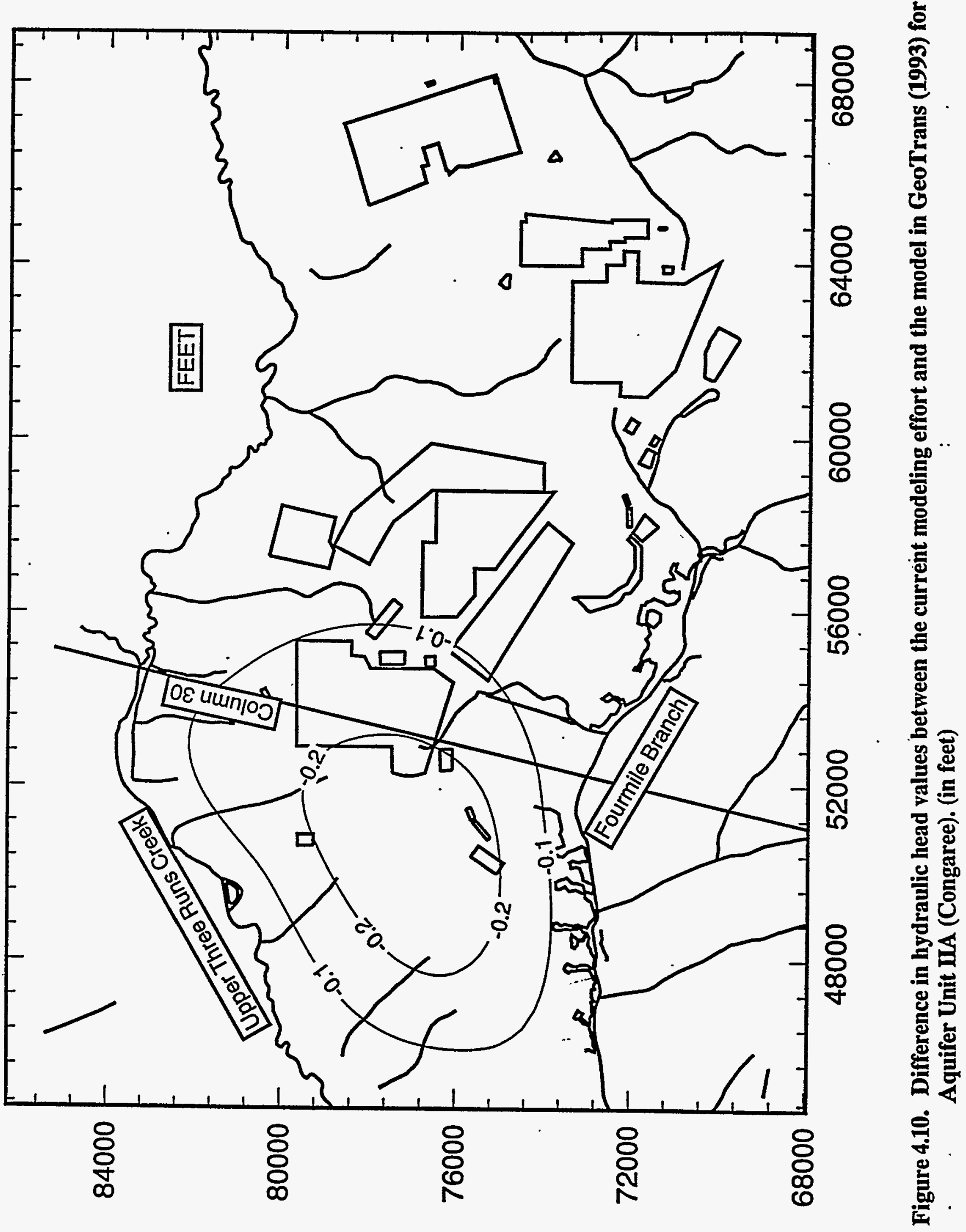




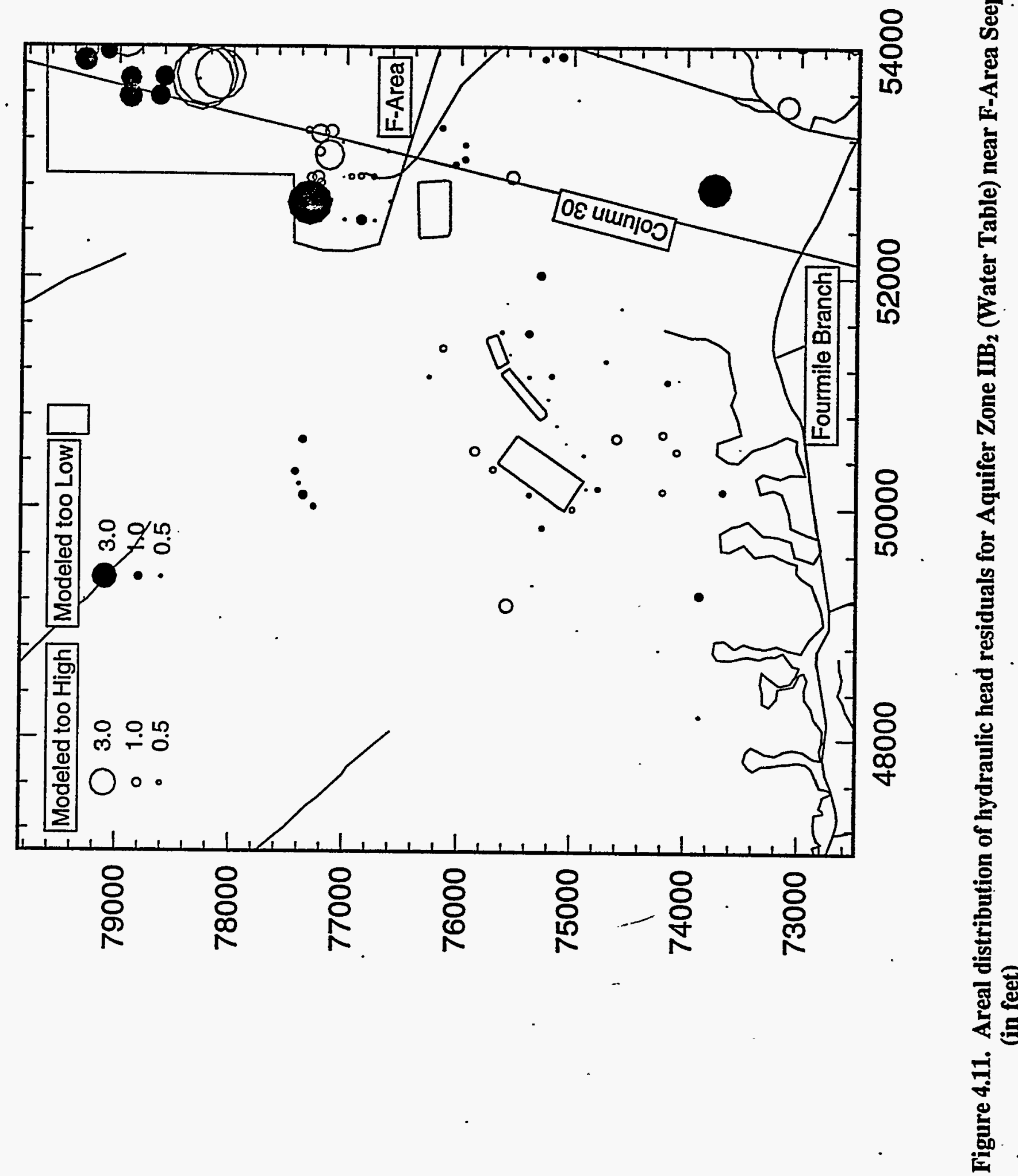



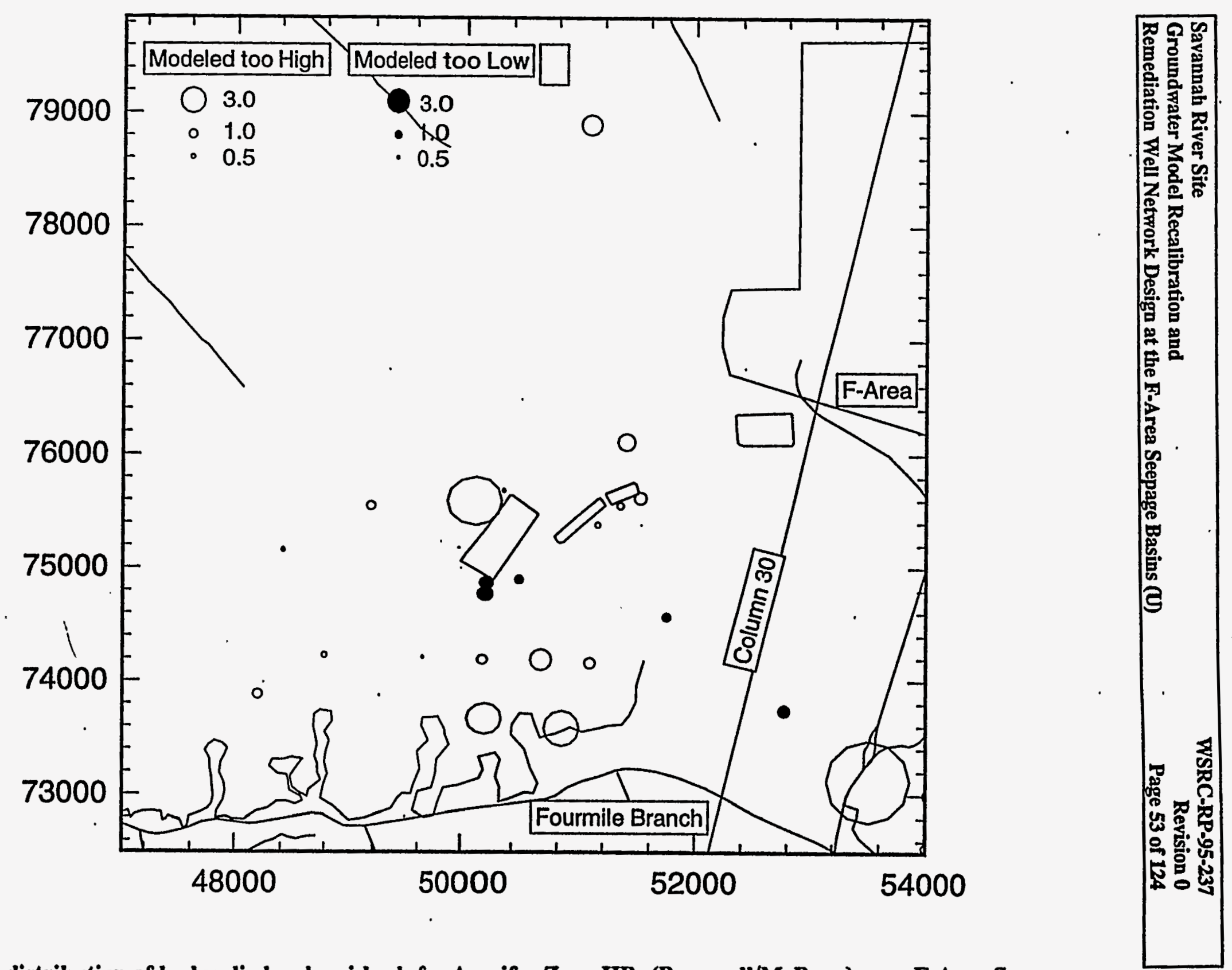

Figure 4.12. Areal distribution of hydraulic head residuals for Aquifer Zone IIB $_{1}$ (Barnwell/McBean) near F-Area Seepage Basins. (in feet) 

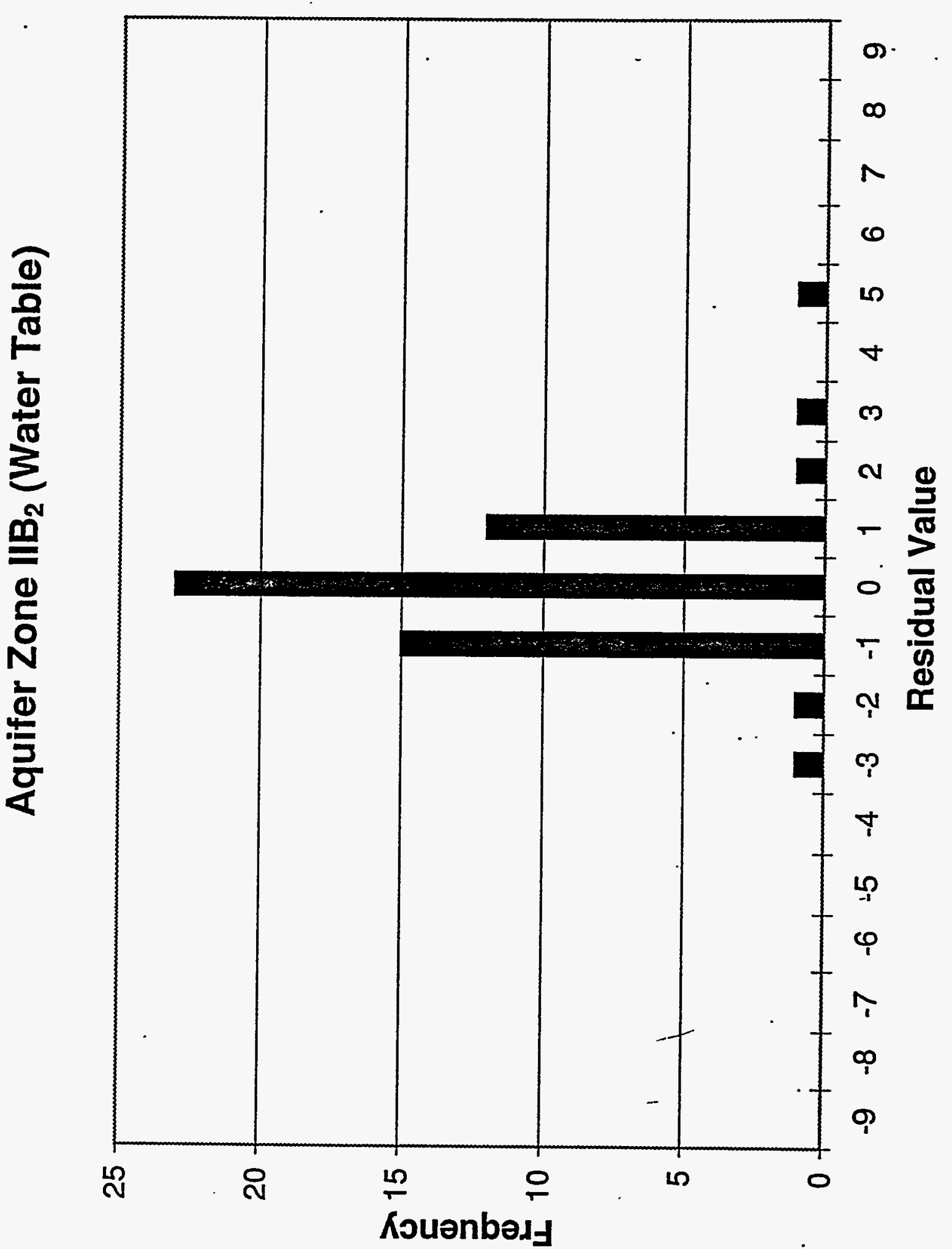
1

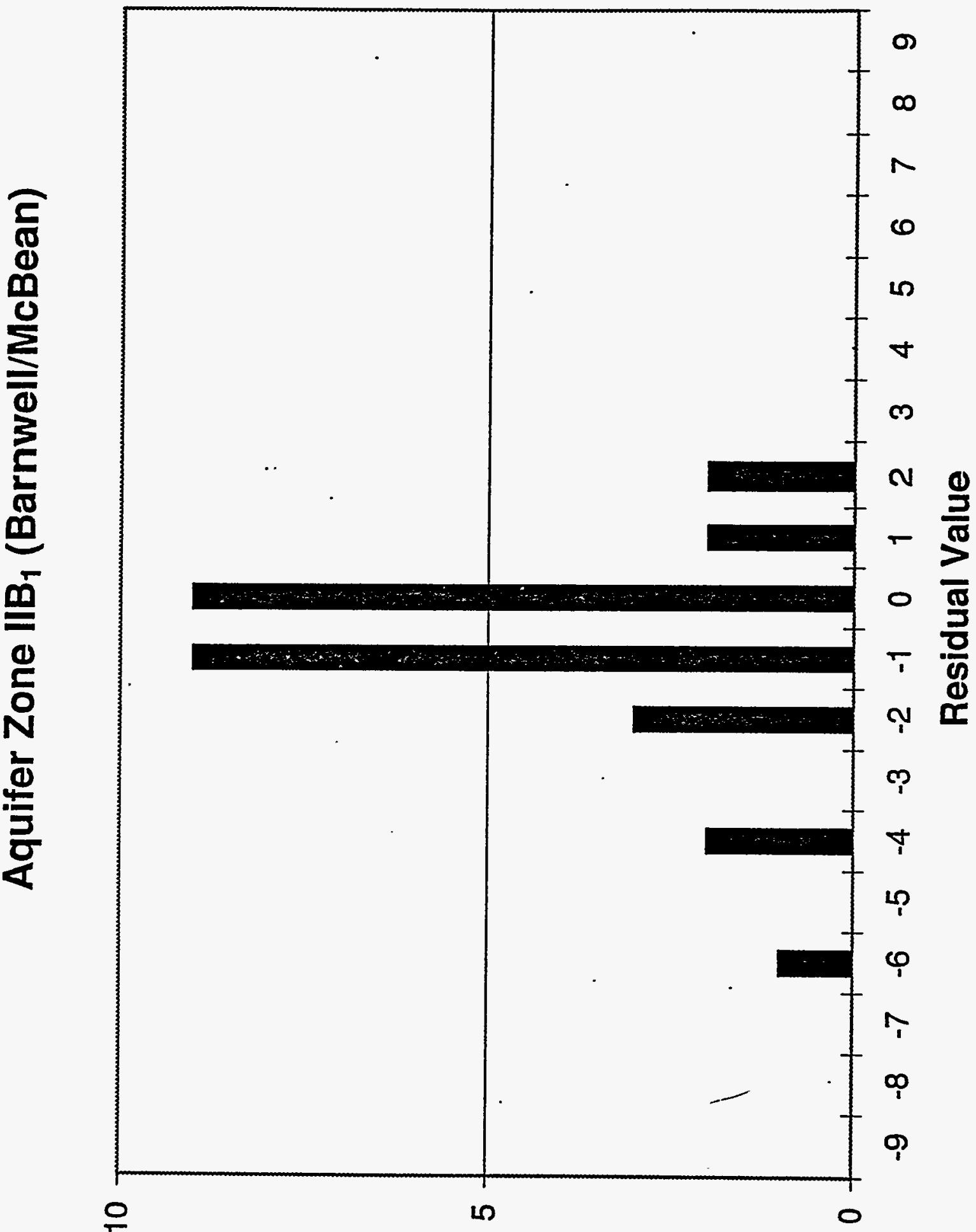

אouanbads

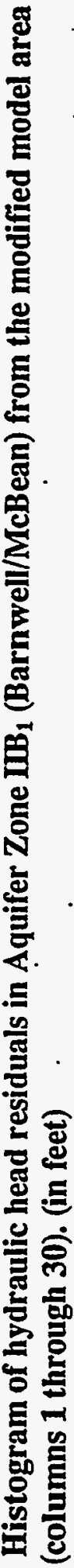




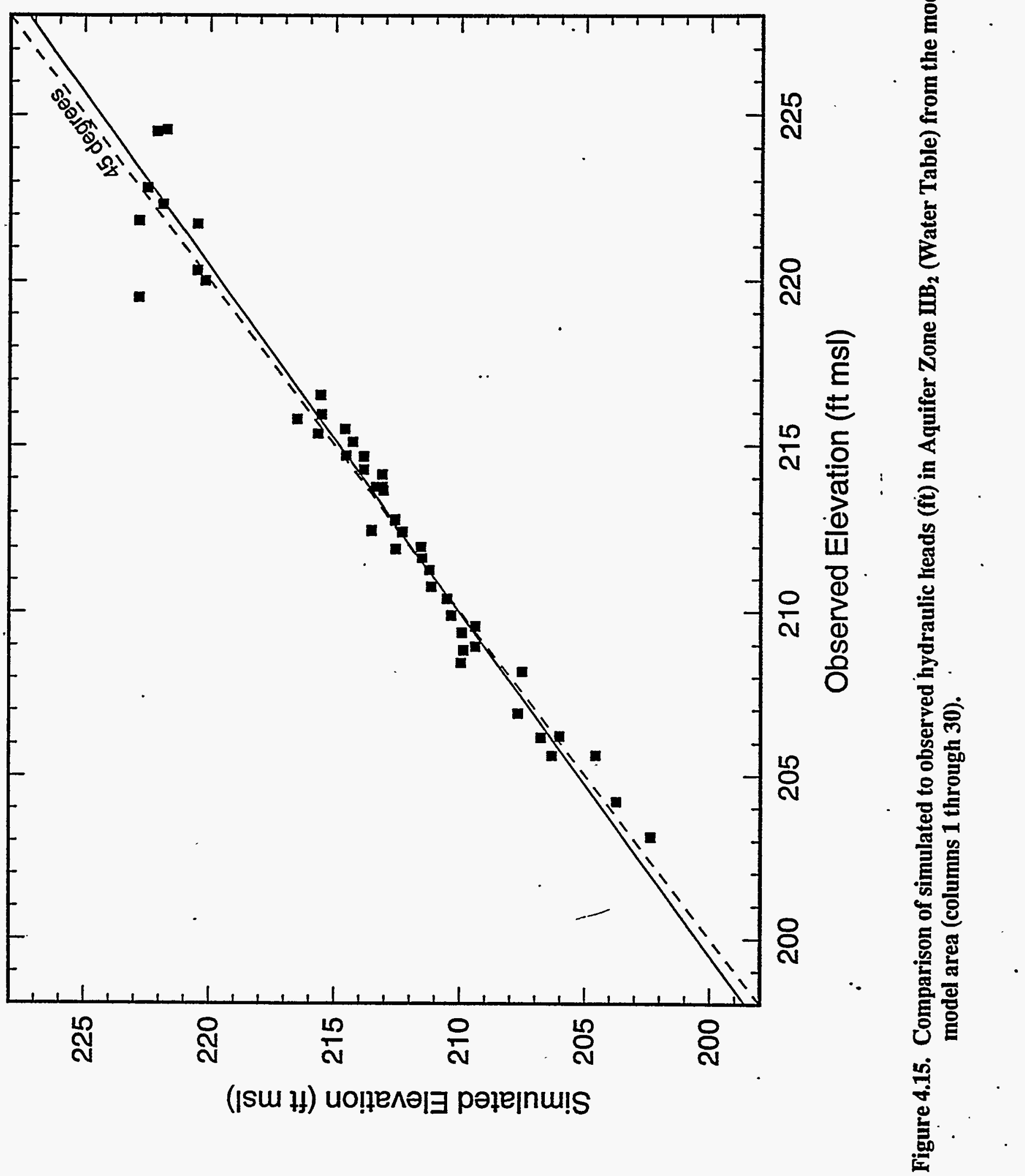




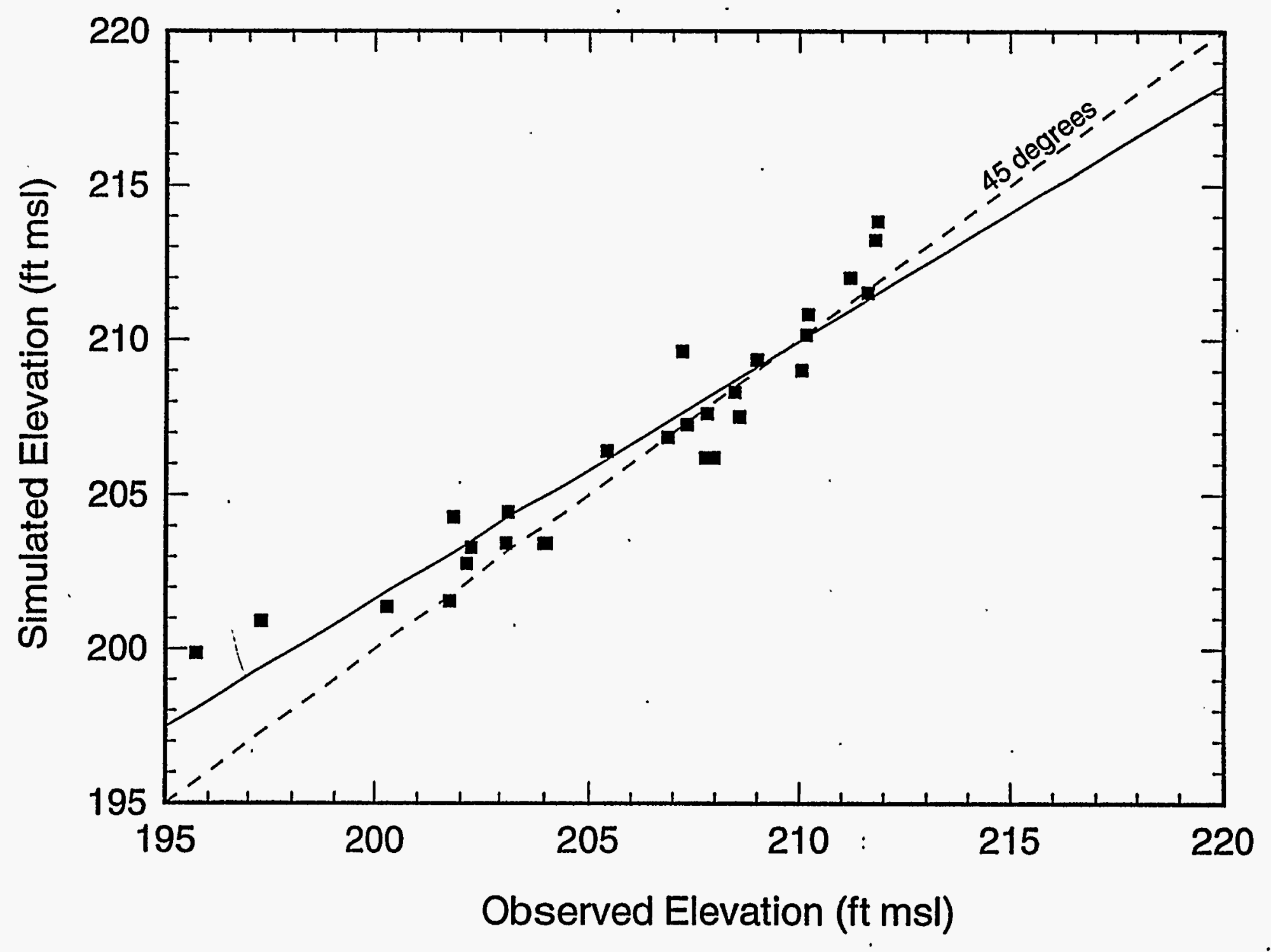

Figure 4.16. Comparison of simulated to observed hydraulic heads ( $f t$ ) in Aquifer Zone $\mathrm{MB}_{\mathbf{1}}$ (Barnwell/McBean) from the modified model area (columns 1 through 30). 
Table 4.4a. Residual head statistics for the modified area and layers.

\begin{tabular}{|l|c|c|}
\hline Parameter & Layer 1 & Layer 3 \\
\hline Number of Observations & 55 & 28 \\
\hline Residual Sum of Squares $\left(\mathbf{f t}^{2}\right)$ & 77.3 & 95.0 \\
\hline Standard Deviation $(\mathbf{f t})$ & 1.19 & 1.70 \\
\hline Residual Mean $(\mathrm{ft})$ & 0.07 & -0.78 \\
\hline
\end{tabular}

Table 4.4b. Residual head statistics for the entire model area.

\begin{tabular}{|l|c|c|c|}
\hline Parameter & Layer 1 & Layer 3 & Layer 5 \\
\hline Number of Observations & 235 & 97 & 44 \\
\hline Residual Sum of Squares $\mathbf{f t}^{2}$ ) & 1715.1 & 1252.8 & 988.5 \\
\hline Standard Deviation $(\mathbf{f t})$ & 2.71 & 3.61 & 1.99 \\
\hline Residual Mean $(\mathbf{f t})$ & 0.08 & 0.17 & 4.31 \\
\hline
\end{tabular}


(

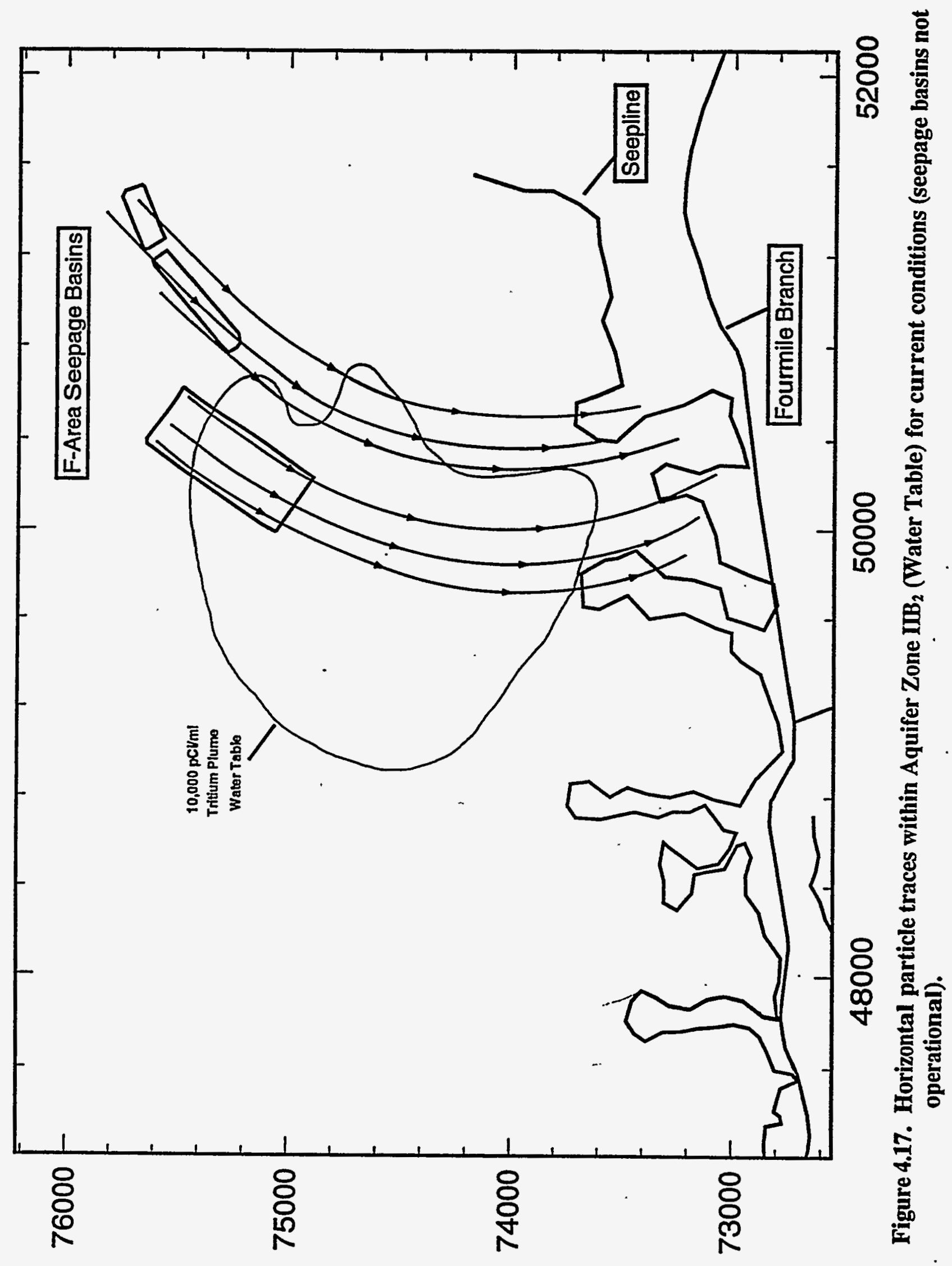


(

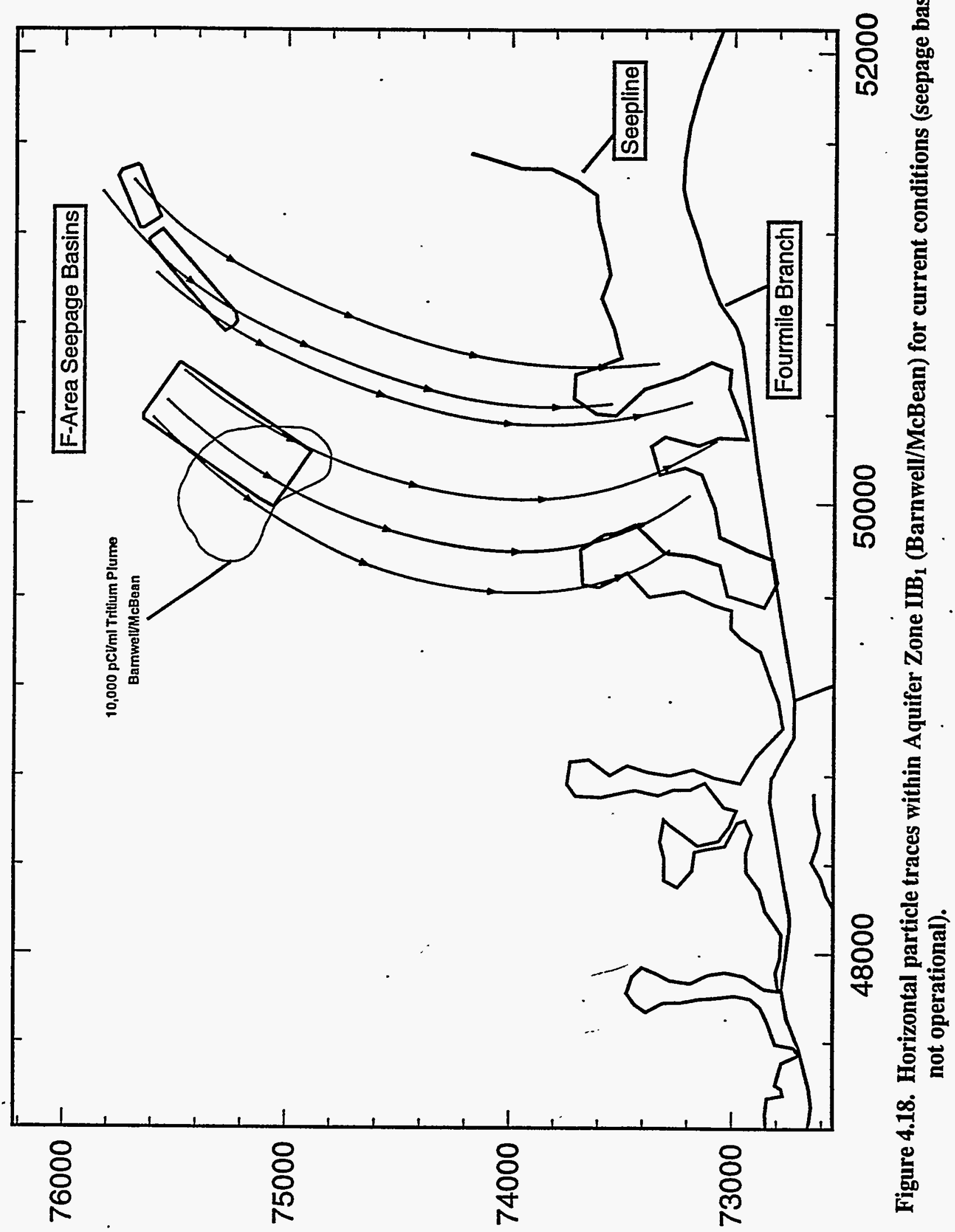


l

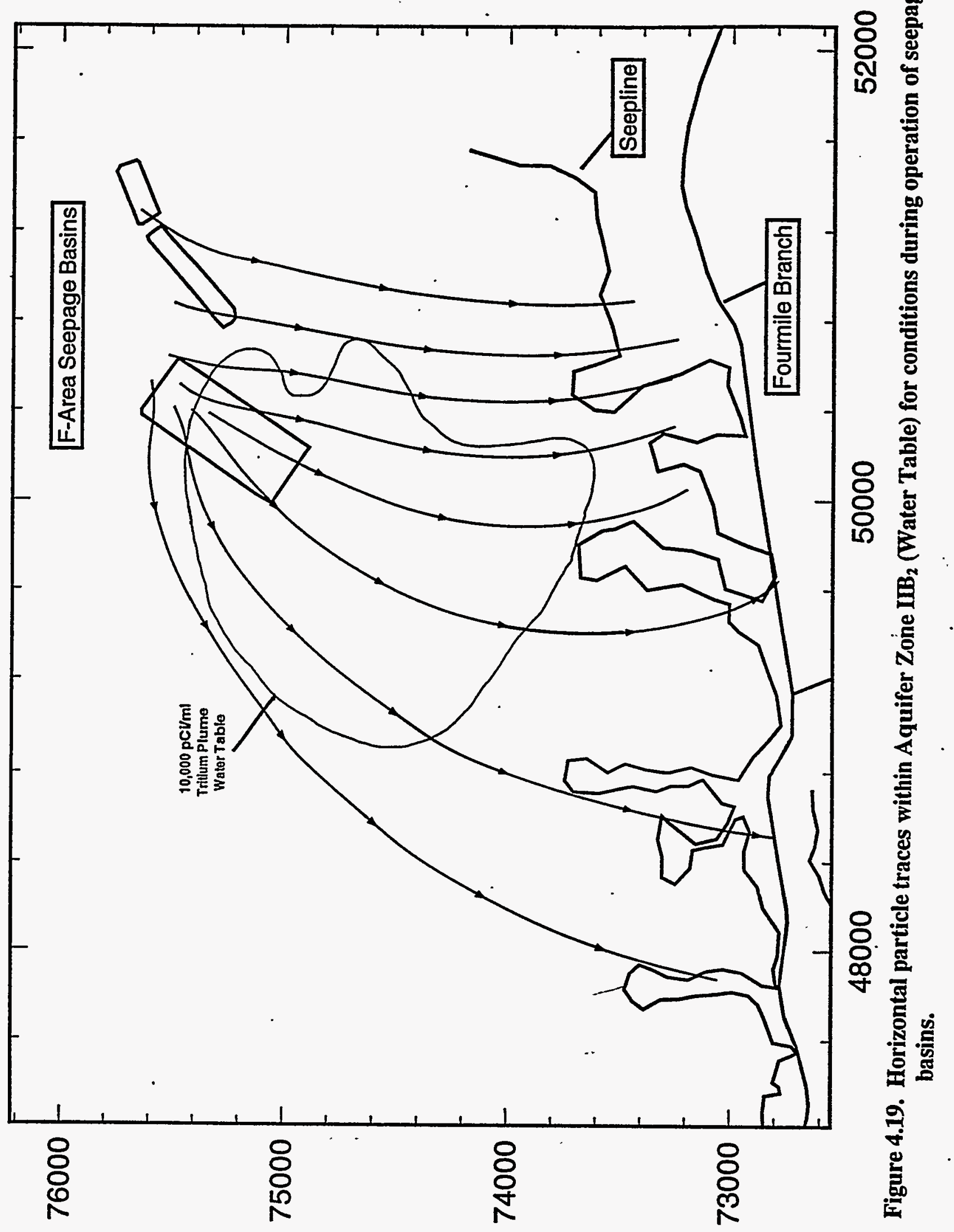


(

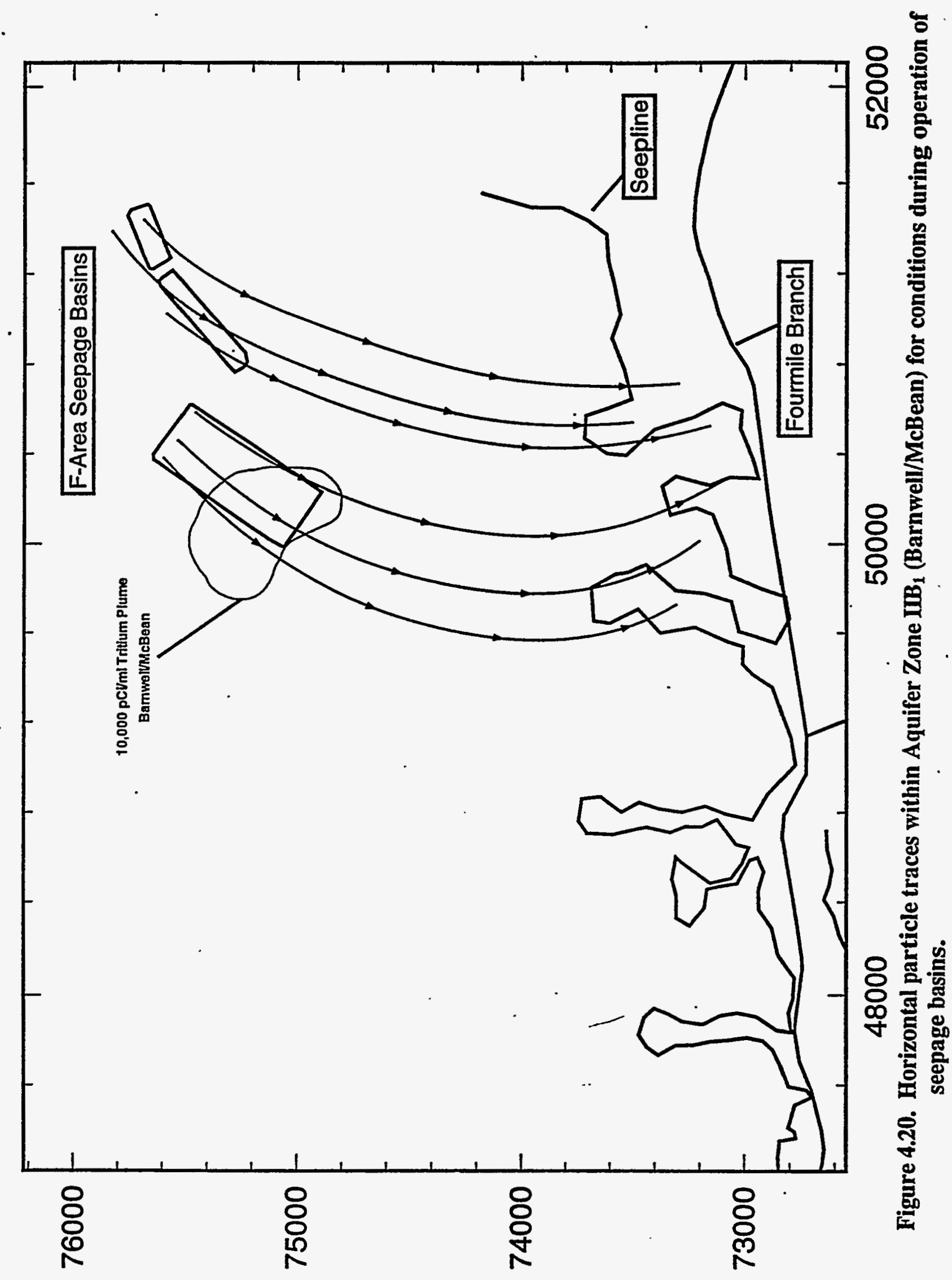


Savannah River Site

Groundwater Model Recalibration and

Remediation Well Network Design at the F-Area Seepage Basins (U)
WSRC-RP-95-237

Revision 0

Page 63 of 124

\subsection{LOCAL TRANSPORT MODEL}

\subsection{Transport Model Setup}

The local transport model was used to simulate the transport of tritium from the seepage basins from 1955 through 1992. The regional model with average seepage basin wastewater inputs was used to determine the hydraulic head values assigned to the constant head boundary nodes on three sides of the model (Section 2.4.3). To account for changes in the volumetric rates and tritium concentrations of wastewater discharged to the basins over time, the flow from the basins was changed annually in the simulations. The flow was simulated as steady-state for each year period and the concentration input was constant for each year period. However, transport was transient throughout the simulations. The same seepage rates and concentrations reported in GeoTrans (1993) were used in this modeling effort. These values and the methodology used to obtain them are discussed in GeoTrans (1993). As with the GeoTrans (1993) effort, the wastewater is assumed to enter Aquifer Zone $\mathrm{IBB}_{2}$ (Water Table) as it leaves the seepage basins (i.e. zero elapse time for solute transport through the unsaturated zone). Therefore, the transport through the unsaturated zone between the basins and Aquifer Zone $\mathrm{IIB}_{2}$ (Water Table) is assumed not to be a significant factor.

Transport parameters used in the local transport model are listed in Table 5.1 and are the same as GeoTrans (1993). The methodology used to obtain these parameter values are explained in GeoTrans (1993).

The time steps used in the transient transport simulations were kept small to reduce time truncation errors. For each change in the basin inputs (annually), the initial time step was 0.1 day. Subsequent time steps were multiplied by a factor of 1.2 until the maximum time step of 5 days was reached. The cell material Courant number is estimated to be less than 0.1 , while the cell Peclet number is 2.1 for most cells.

\subsection{Transport Model Results}

Simulated tritium concentrations for years 1962 and 1992 are presented in Figures 5.1 through 5.4. Simulated tritium concentrations for years $1970,1978,1986,1988$, and 1991 are in Appendix 3 . The simulated plumes roughly match observed plumes and are similar to those simulated in GeoTrans (1993). For 1992, the simulated plumes within Aquifer Zone $\mathbb{I B}_{2}$ (Water Table) have lower tritium concentrations in the plume center near the basins than the observed plumes, while near the plume edge the simulated concentrations are higher. Simulated tritium concentrations within Aquifer Zone $\mathrm{IB}_{1}$ (Barnwell/McBean) are similar to observed. The simulated 1962 plume within Aquifer Zone $\mathrm{IB}_{2}$ (Water Table) has much higher tritium concentrations and the plume front has advanced further than measured.

Since 1958, the quantity of tritium discharged to Fourmile Branch has been calculated. These quantities are presented in GeoTrans (1993). Figure 5.5 shows three graphs of the tritium activity 
discharged to Fourmile Branch over time from the vicinity of the F-Area Seepage Basins: 1) calculated from measurements, 2) simulated from this modeling effort, and 3) simulated from the modeling effort reported in GeoTrans (1993). In general, the two simulated graphs are more similar to each other than they are to the observed data. The simulated graphs overpredict tritium flux at earlier times, underpredict the tritium flux at later times and are reasonably close at intermediate times.

A probable cause for much of the difference between the simulated and observed tritium transport near the F-Area Seepage Basins is the inadequate definition of the tritiated wastewater input through the vadose zone into Aquifer Zone $\mathrm{IB}_{2}$ (Water Table). The unsaturated zone between the basins and the top of the water table is ignored. The unsaturated zone beneath the basins is approximately 50 feet thick, consisting of alternating sandy and clayey layers. Reichert and Fenimore (1962) describe a perched water table which developed about 5 to 20 feet below the basins. Matching fluctuations of tritium concentrations within the basins and within observation wells within the perched water table, the vertical movement of water to the perched water table was estimated to be from 0.9 to 0.1 feet per day. The report also estimates the vertical flow from the perched water table to the top of the normal water table (about 40 feet) to be on the order of 0.1 feet per day or less.

Therefore, the time lapse between wastewater addition to the F-Area Seepage Basins and its addition to Aquifer Zone $\mathrm{IB}_{2}$ (Water Table) was not negligible. In addition, during the early period of basin operation, wastewater was going into storage to create the perched water table under the basins, and to increase the water content within the pores of the still unsaturated zone. A significant amount of water is required to accomplish this. As water traveled between the basins and the top of Aquifer Zone $\mathrm{IBB}_{2}$ (Water Table), mixing of the tritium would occur along with radioactive decay. The mixing would tend to smooth out the tritium concentration highs and lows and the decay would cause a slight decrease of tritium concentrations as it entered Aquifer Zone $\mathrm{IB}_{2}$ (Water Table). After the removal of the F-Area Seepage Basins from operation, tritiated water would still be slowly added to Aquifer Zone $\mathrm{IB}_{2}$ (Water Table) as the perched water table and the pores within unsaturated zone drained. Therefore, the source of tritium would continue for some time period after the cessation of seepage at the basins.

This conceptual model would help account for:

A) the simulated tritium plume advancing further than measured at early periods (time lapse between input to basin and input to Aquifer Zone $\mathrm{IB}_{2}$ (Water Table));

B) the simulated tritium plume having lower tritium concentrations near the basins at later non-operational periods (time lapse between cease of basin operation and the cease of tritium added to Aquifer Zone $\mathrm{IBB}_{2}$ (Water Table);

C) the overprediction of tritium flux to Fourmile Branch at early periods (same reasoning as "A")

D) the underprediction of tritium flux to Fourmile Branch at late periods (same reasoning as " $B$ ") 
Because the transport modeling does not directly effect the objective of this modeling project (development of a remediation well network to control measured plumes) the incorporation of this conceptual source input was not included in the current modeling effort. However, if the simulation of tritium (or other contaminant) from the F-Area Seepage Basins becomes a critical issue, the source input should be revised. The distance between the H-Area Seepage Basins and Aquifer Zone $\mathrm{IIB}_{2}$ (Water Table) is much less than for the F-Area, and the assumption of immediate input and cessation of wastewater may be more valid.

The total amount of tritium simulated to move into Aquifer Zone IA (Congaree) from 1955 to 1992 is 2019 Curies. Considering the thickness and groundwater flow rate within this aquifer zone, the resultant concentration is small, as observed in field measurements.

\subsection{Transport Simulations for 1992 - 1997}

The transport simulations were continued from 1992 to 1997 to look at simulated tritium concentrations at the proposed startup time for the remediation well network. The results are shown in Figures 5.6 and 5.7. The simulated concentrations are low. However, because the simulated concentrations for Aquifer Zone $\mathrm{IB}_{2}$ (Water Table) for 1992 are lower than observed for the center portion (highest concentration) of the plume and because of the aforementioned questions pertaining to the modeled tritium source, the results for 1997 are questionable and should be used for trend information only. 
Table 5.1. Transport parameters used for transport model simulations. The parameters were used for the entire model.

\begin{tabular}{|ll|}
\hline Transport Parameter & Parameter Value \\
\hline Longitudinal Dispersivity & 21.3 feet \\
Transverse Dispersivity & 2.13 feet \\
Adsorption Coefficient $\left(\mathrm{K}_{d}\right)$ & 0 \\
Radioactive Decay Constant & $1.54 \times 10^{-4} /$ day \\
Effective Porosity & \\
Aquifer Units & 0.2 \\
Confining Units & 0.3 \\
\hline
\end{tabular}




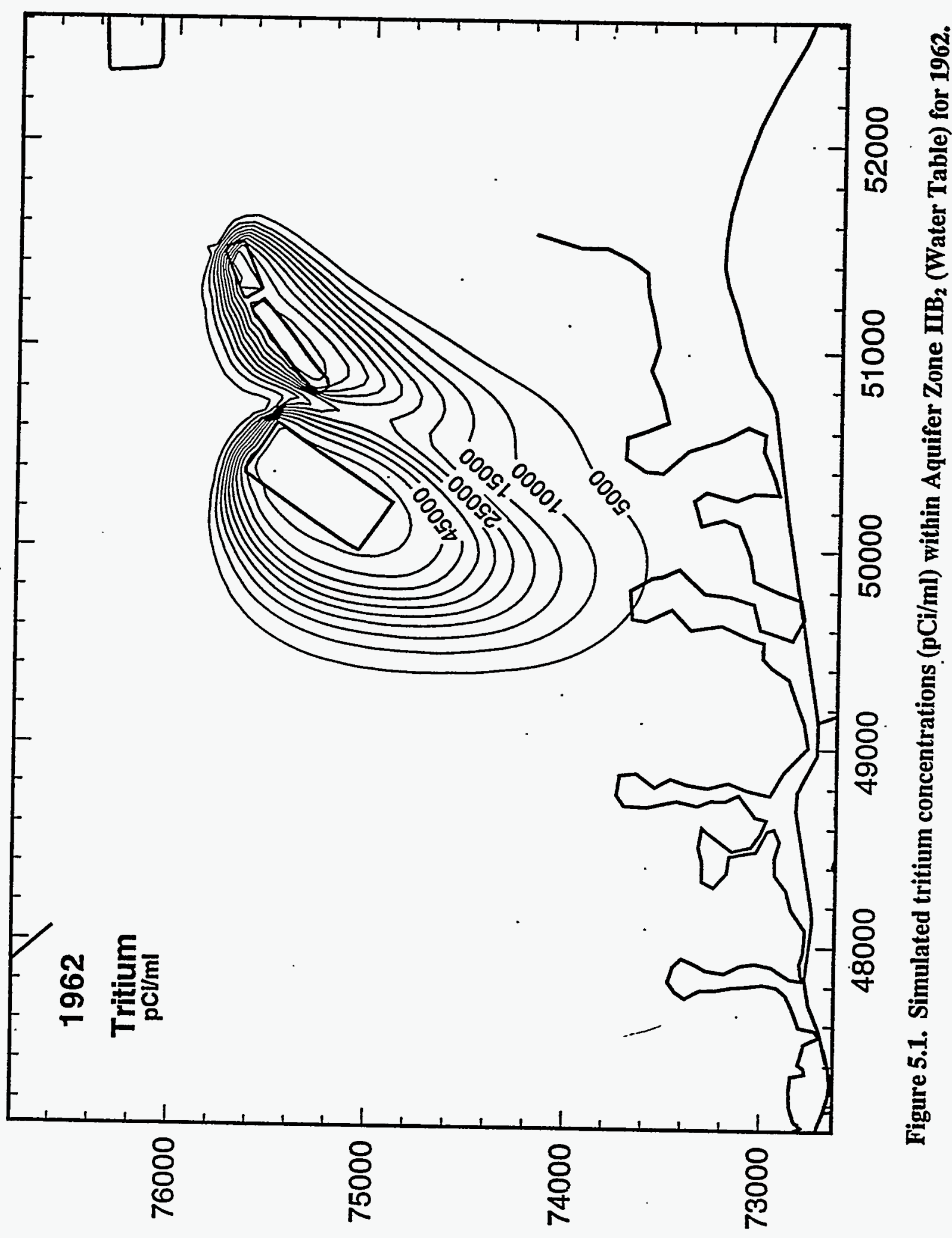




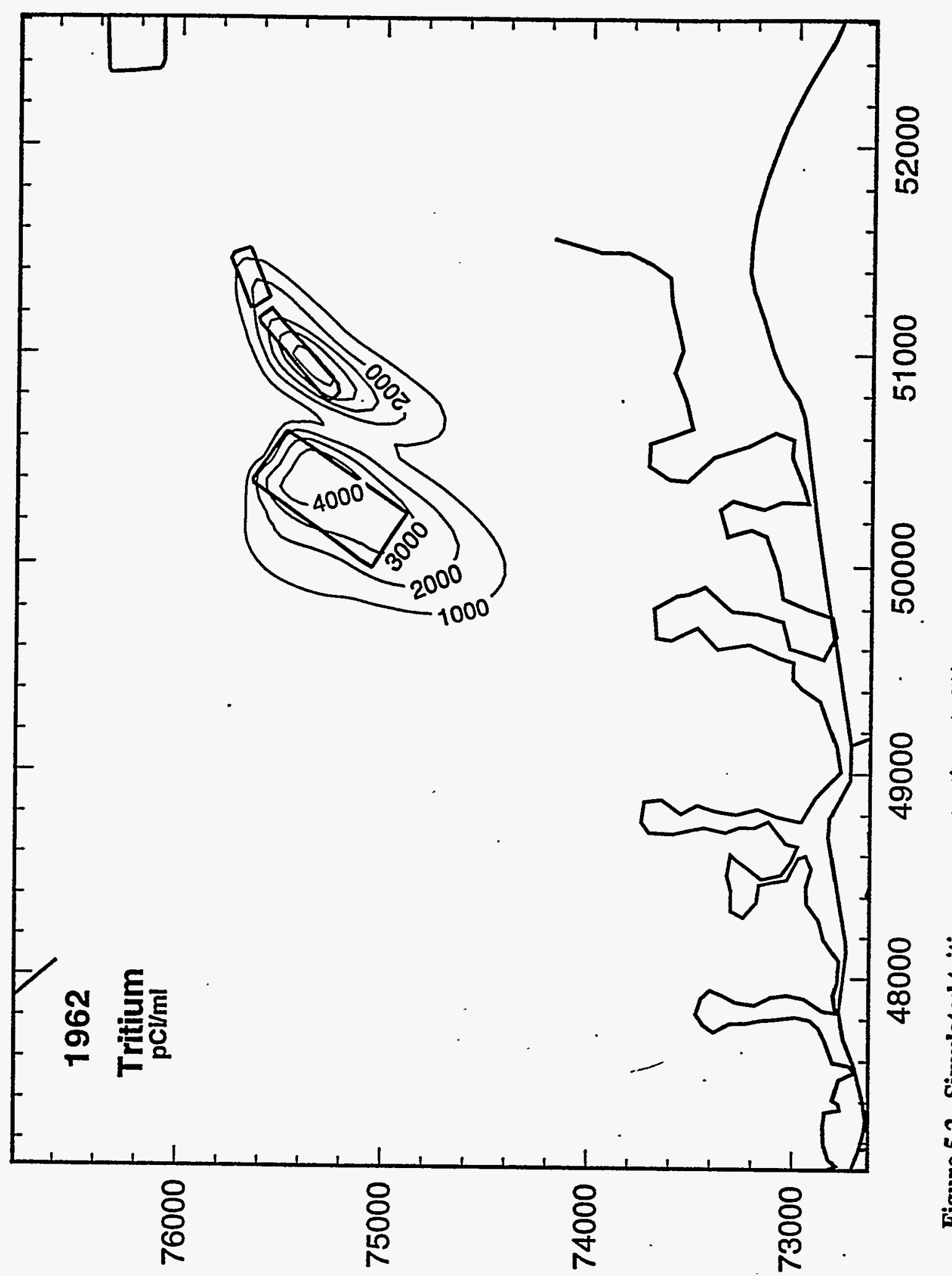

宫 


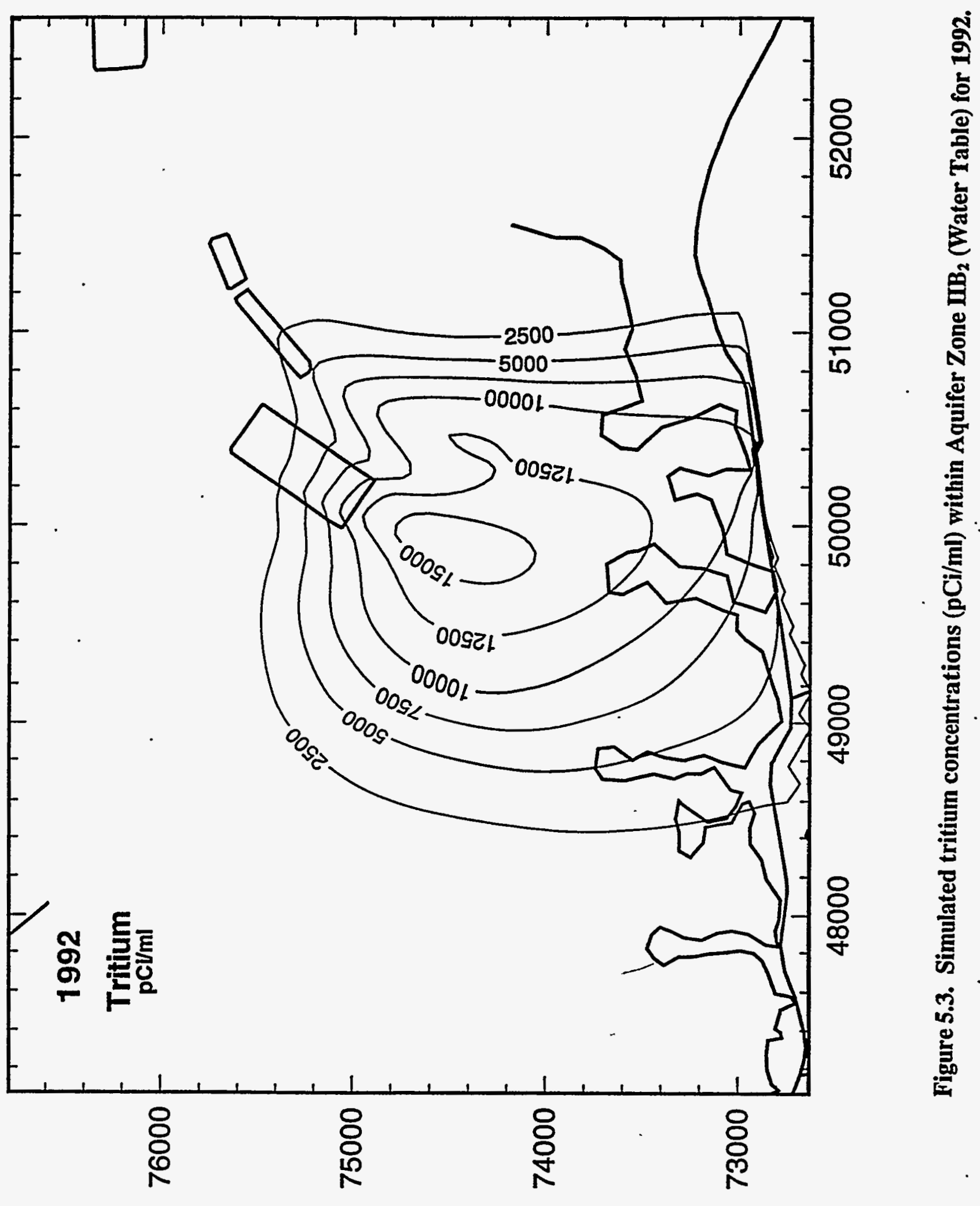




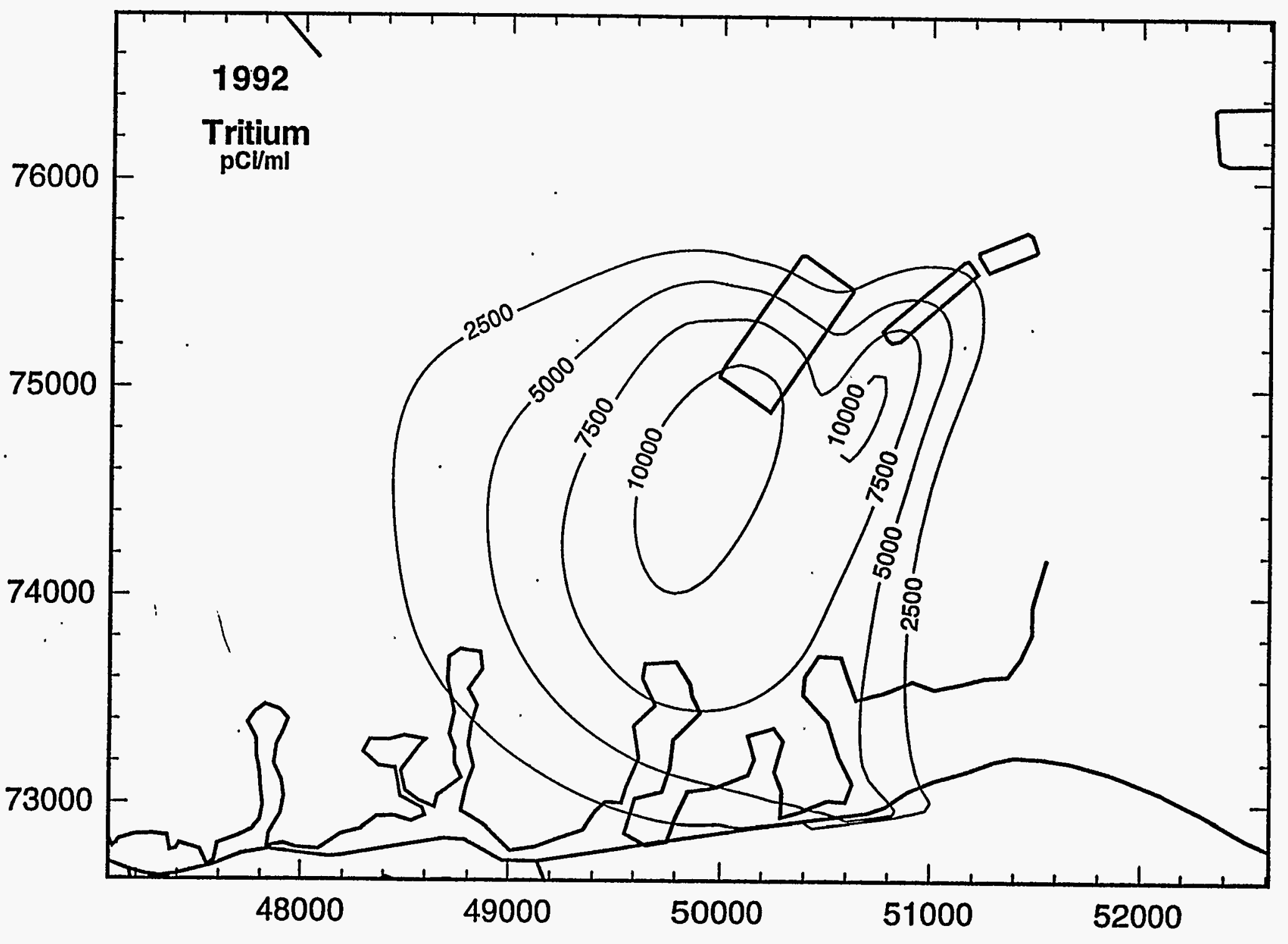

Figure 5.4. Simulated tritium concentrations (pCi/ml) within Aquifer Zone $\mathbf{U B}_{1}$ (Barnwell/McBean) for 1992. 


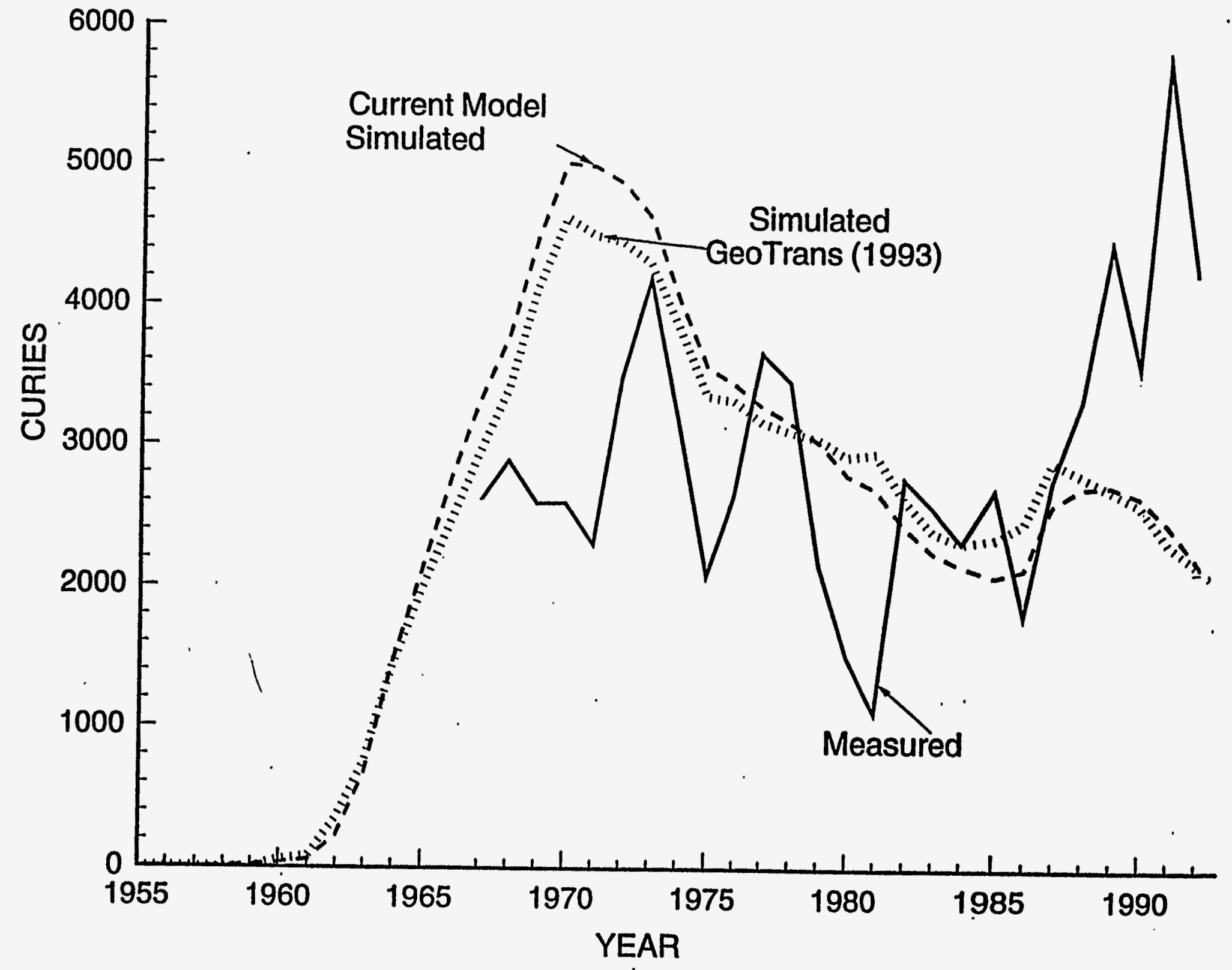

Figure 5.5. Tritium activity discharged to Fourmile Branch over time from the vicinity of the F-Area Seepage Basins. Graphs are: 1) calculated from measurements, 2) simulated from this modeling effort, and 3) simulated from modeling effort reported in GeoTrans (1993). 


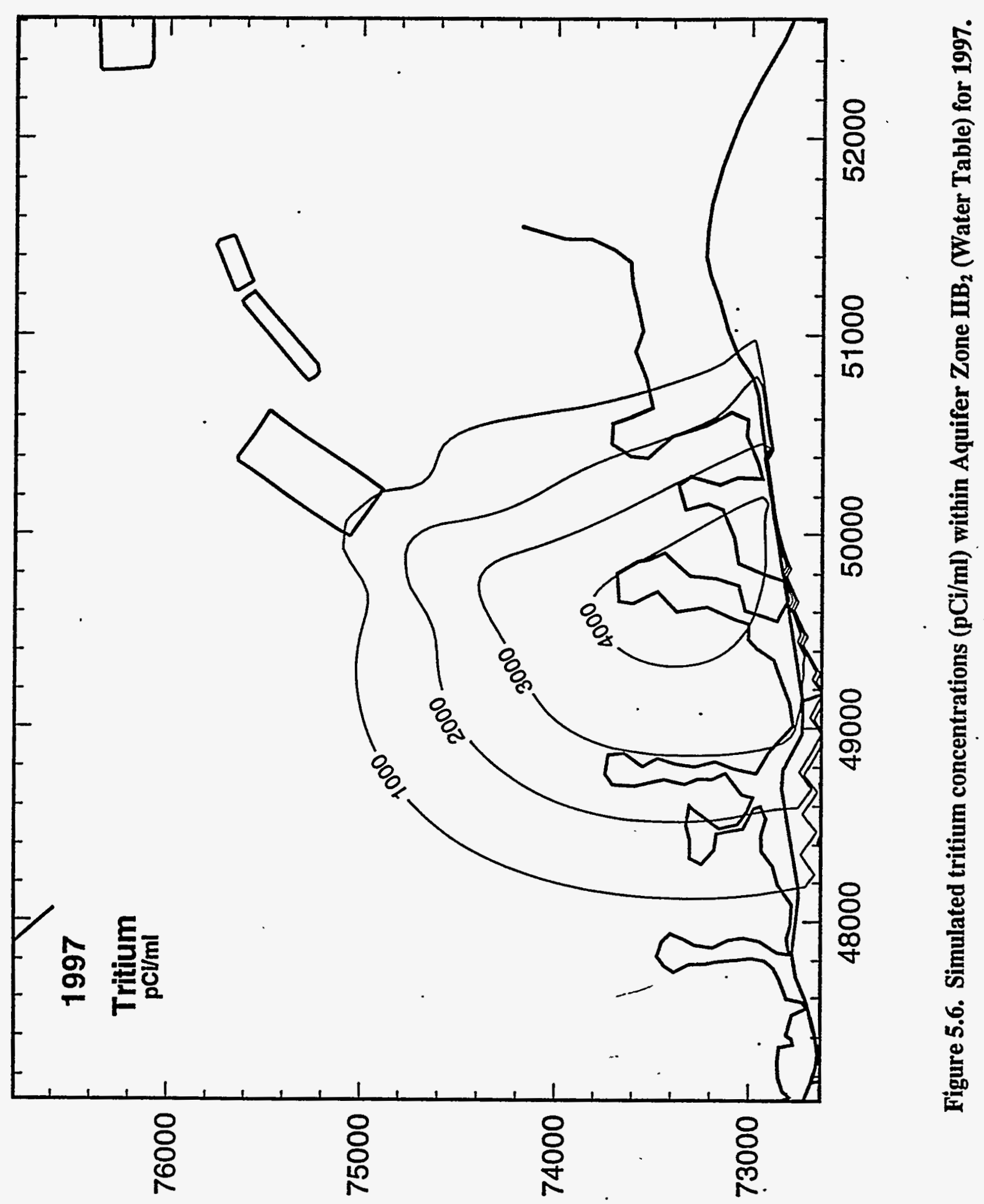




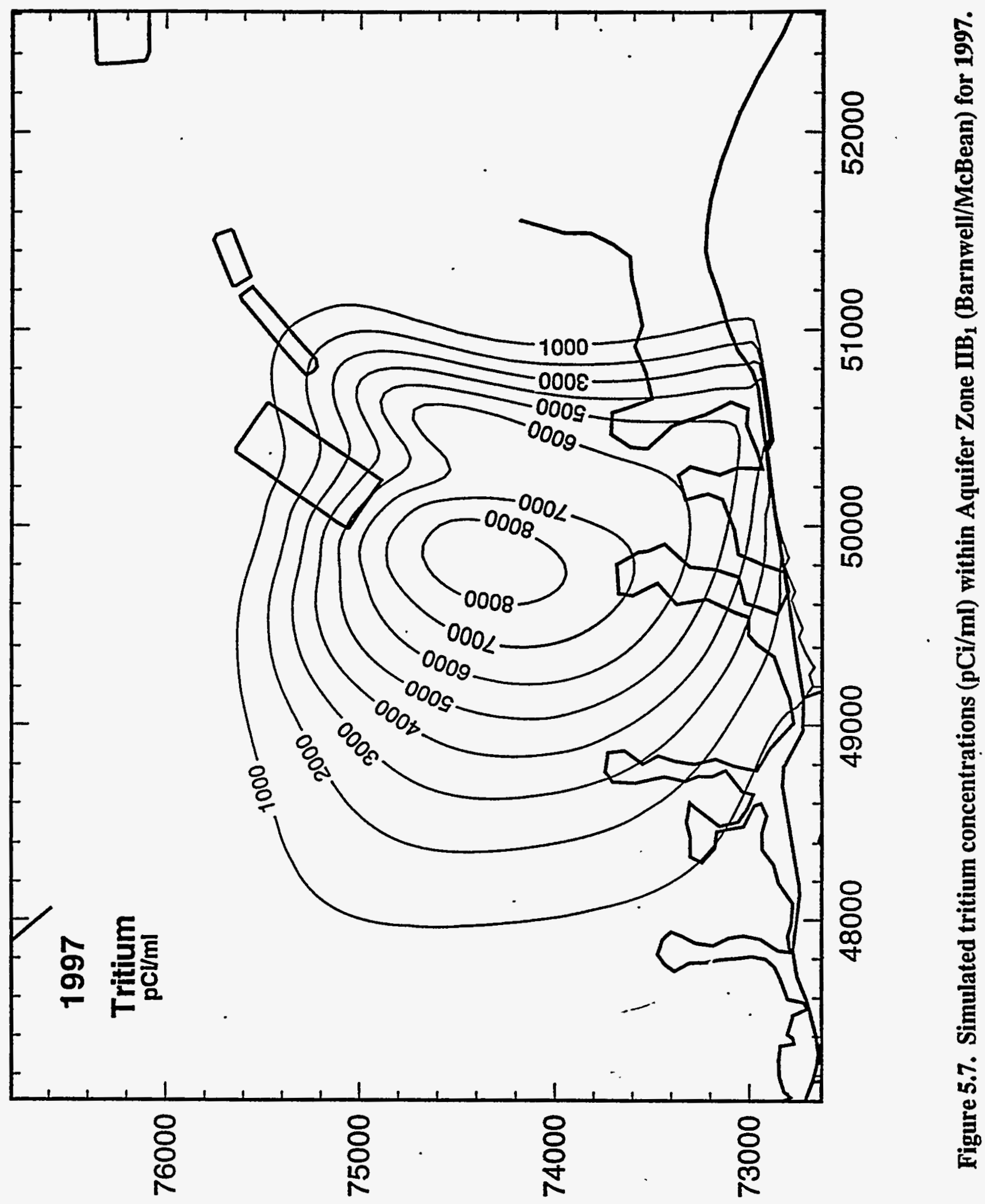




\subsection{REMEDIATION WELL NETWORK}

\subsection{Objective and Approach}

The remediation well network was simulated using both the regional and local flow models. For each well network scenario, the specific wells and flow rates were simulated using the regional model. The output from the regional model was used to create the boundary conditions for the local flow model which also simulated the specific wells and flow rates. Thirty-six different well network scenarios were simulated. All scenarios simulated the wells as being fully screened across the specified aquifer zone.

The conceptual plan for the remediation well network is to extract groundwater downgradient of the F-Area Seepage Basins which is contaminated with tritium, other radionuclides, metals, nitrate, etc. The water will be treated to remove most constituents. However, because the treated water will still be tritiated, it will be reinjected into the aquifer zones upgradient of the seepage basins. The conceptual plan will provide some recirculation of the tritium to allow more time for radioactive decay before naturally discharging to Fourmile Branch. It has been recognized that a complete recirculation system is not possible due to the addition of water to the system through natural means such as recharge from precipitation (GeoTrans, 1990a, 1990b, 1991, 1993; McMullin, 1993).

Objectives used in the development of the remediation well network were:

1) extraction well network must capture the $10,000 \mathrm{pCi} / \mathrm{ml}$ plume as defined in the Corrective Action Program section of the 1992 RCRA Part B Permit Renewal Application (WSRC, 1992a).

2) extraction well locations should conceptually have the ability to capture the required plumes under a variety of hydraulic conductivity distributions (i.e. taking into account. model uncertainties).

3) estimated drawdowns within extraction wells must be physically possible. A well efficiency of 33 percent was used to be conservative. At least 10 feet of aquifer thickness is to be left at steady-state pumping within Aquifer Zone $\mathrm{IBB}_{2}$ (Water Table) and no dewatering within Aquifer Zone $\mathrm{IB}_{1}$ (Barnwell/McBean).

4) minimize pumping. This leads to less operational costs and more time between the injection and subsequent extraction of the tritiated water (recirculation).

5) extraction well network location should allow for some metal plume movement before activation of the remediation system; tritium movement was deemed less important.

6) extraction well network location should not be located in or between wetland areas and Fourmile Branch.

7) injection well network should reinject the same amount of water into.an aquifer zone as was extracted.

8) injection well network should supply water to the extraction well network, as well as possible, to enhance recirculation. 
9) injection well locations and flow rates cause excess injection water (not recaptured by extraction network) to flow largely toward Fourmile Branch and not Upper Three Runs Creek.

10) injection well locations are upgradient of seepage basins, not within metal plumes, and not within 150 feet of the seepage basins. This is to increase time for recirculation and to reduce spreading of the metal plumes.

\subsection{Results}

Three different well network scenarios are shown in Figures 6.1 through 6.6 to show how the project progressed.

1) Figures 6.1 and 6.2 show well locations for an early well network scenario during the current modeling effort.

2) Figures 6.3 and 6.4 show well locations for the simulated well network before the decision to utilize well locations specified in GeoTrans (1993) where possible and before field verification.

3) Figures 6.5 and 6.6 and Table 6.1 presents well locations, flow rates, and estimated drawdowns for the final well network.

Most of the difference in well locations between scenarios 1 and 2 is with the injection wells; there is little change in extraction well locations. The changes in injection well locations were due to the tendency of the injected water in both aquifer zones to shift the groundwater divide, causing the injected water to travel toward Upper Three Runs Creek. To alleviate the problem, the injection wells were separated by larger distances and most were placed perpendicular to the regional gradient. The shift in the injection wells were toward plant east instead of plant west because: 1) the distance from the injection wells to the natural groundwater divide is larger in this. direction, 2) injection wells to the east will push the metal plumes toward areas of current contamination instead of in a different direction, and 3) the spread of injected water is larger with the wells placed toward the plant west.

The difference in well locations between scenarios 2 and 3 was caused by two factors; the decision to utilize well locations specified in GeoTrans (1993) where possible and a newly constructed pipeline just upgradient of the seepage basins. The four easternmost extraction wells within Aquifer Zone $\mathrm{IB}_{2}$ (Water Table) were changed to correspond to wells specified in GeoTrans (1993). The largest change due to the construction project upgradient of the seepage basins was the relocation of an injection well from near the center of the injection well line to the western end of the line.

The final remediation well network for the F-Area Seepage Basins consists of seven extraction wells and seven injection wells within Aquifer Zone $\mathrm{IB}_{2}$ (Water Table). The total simulated pumping rate for this zone is 139 gallons per minute. The well network within Aquifer Zone $\mathbb{I I B}_{1}$ (Barnwell/McBean) consists of two extraction wells and two injection wells with a simulated 
pumping rate of 26 gallons per minute. The total estimated flow rate for F-Area is approximately 165 gallons per minute.

The extraction wells within Aquifer Zone $\mathrm{IB}_{2}$ (Water Table) are spread across the front of the defined plume and located 220 to 280 feet apart. The simulated capture zone for each well is dependent on the simulated aquifer drawdown caused by the well. If the hydraulic parameters are found to be different under actual field conditions than simulated in the model, the pumping rates of individual wells can be increased or decreased to compensate. With the above well spacing and well locations relative to the plume, a wide variety of heterogeneities can be compensated for. The extraction wells within Aquifer Zone IIB $_{1}$ (Barnwell/McBean) are spaced 365 feet apart. The defined plume can probably be captured with the use of only one of these wells pumping at a higher rate. Two wells were used to reduce the risk of one well being relatively isolated from the contaminated area due to local zones of low hydraulic conductivity.

The injection wells in both aquifer zones are simulated to inject approximately one-half of the injection rate used during aquifer injection testing (Sadler, 1993). This is to account for possible local zones of reduced hydraulic conductivity and for clogging over time. Clogging of the injection wells is probable over time, however, the decision was made to address this problem as it arises and not simulate alternate injection well locations.

The drawdown/mounding within each well was estimated by:

1) calculating the theoretical drawdown in a 100 percent efficient well using total simulated drawdowns from the finite difference model. This method is described in Section 5.1 of Anderson and Woessner (1992) and includes drawdown from nearby wells;

2) calculating the theoretical drawdown in a single 100 percent efficient well using the steady-state unconfined aquifer Dupuit formula for Aquifer Zone $\mathrm{IB}_{2}$ (Water Table) and the steady-state leaky aquifer DeGlee formula for Aquifer Zone $\mathrm{IIB}_{1}$ (Barnwell/McBean) (see Kruseman and de Ridder (1991) or other for formula explanations);

3) multiplying the value from step 2 by one minus the well efficiency and adding the result to the value from step 2 . This adds additional drawdown to the estimation due to the individual well inefficiency;

4) adding the values from step 1 and step 3 for the total estimated drawdown/mounding.

Figures 6.7 and 6.8 show hydraulic head distributions for Aquifer Zone $\mathrm{IBB}_{2}$ (Water Table) and Aquifer Zone IBB $_{1}$ (Barnwell/McBean) with the remediation well network active. Extraction well capture zones for each aquifer zone are shown in Figures 6.9 and 6.10, while particle traces from the injection wells are shown in Figures 6.11 and 6.12. The objective plumes in both zones are captured by the extraction well network. Most of the recirculated water will be from the westernmost wells, however, there are particle traces from the injection wells which bypass the extraction well network on both the eastern and western ends. The result of moving the easternmost wells to the west increases the spreading of the injectate toward Upper Three Runs Creek and into uncontaminated areas further west. 


\subsection{Fate of Injectate}

To assess the percentage of injectate which is recaptured by the extraction well network, 331 particles were placed along the cell faces which contained injection wells using MODPATH (Pollock, 1989). The number of particles placed on each cell face was directly proportional to the amount of flow through the cell face. The tracking was based on the simulated steady-state flow field in three dimensions. Approximately 60 percent of the particles were recapture. Approximately 40 percent went around or under (in a separated aquifer zone) the extraction well network. The reason for the majority of this loss is addition of water to the recirculation system from precipitation recharge for Aquifer Zone $\mathrm{IIB}_{2}$ (Water Table) and from leakage across Confining Zone $\mathrm{IBB}_{1}-\mathrm{IBB}_{2}$ (Tan Clay) into Aquifer Zone $\mathrm{IB}_{1}$ (Barnwell/McBean).

To help assess the effect of the injection wells on the spread of relatively high concentrations of tritium in areas where the injectate is not recaptured, a simple transport scenario was simulated. The model scenario incorporated the same hydraulic and transport parameters as the local transport model reported in Section 5.0. However, the remediation well network was also included and the initial concentration values were set to zero. The injection wells were then simulated to inject a tritium concentration of $10,000 \mathrm{pCi} / \mathrm{ml}$ for 30 years. The resulting tritium concentrations are shown in Figures 6.13 and 6.14. These figures indicate that the concentration of tritium which is forced outside of the extraction well network capture zone by injection will be fairly low. Only a small amount of tritium may be forced toward Upper Three Runs Creek and toward the west. The largest concentration of tritium outside of the extraction well network capture zones is on the eastern side of the reinjection plume. This area may have to be addressed in Phase II of the F\&H Area Seepage Basins Groundwater Remediation Project. The existence of a Phase II for this project is one reason the injection wells were located to keep most of the uncaptured injectate in one area.

The concentrations shown in Figures 6.13. and 6.14 are less than the input of $10,000 \mathrm{pCi} / \mathrm{ml}$ because of:

1) dilution from the addition of recharge water from precipitation (zero $\mathrm{pCi} / \mathrm{ml}$ ) for Aquifer Zone $\mathrm{IB}_{2}$ (Water Table) and dilution from leakage from Aquifer Zone $\mathrm{IBB}_{2}$ (Water Table) (less than 10,000 pCi/m) to Aquifer Zone III ${ }_{1}$ (Barnwell/McBean).

2) dilution from mixing with water from upgradient (limited to plume edges)

3) loss from radioactive decay. 


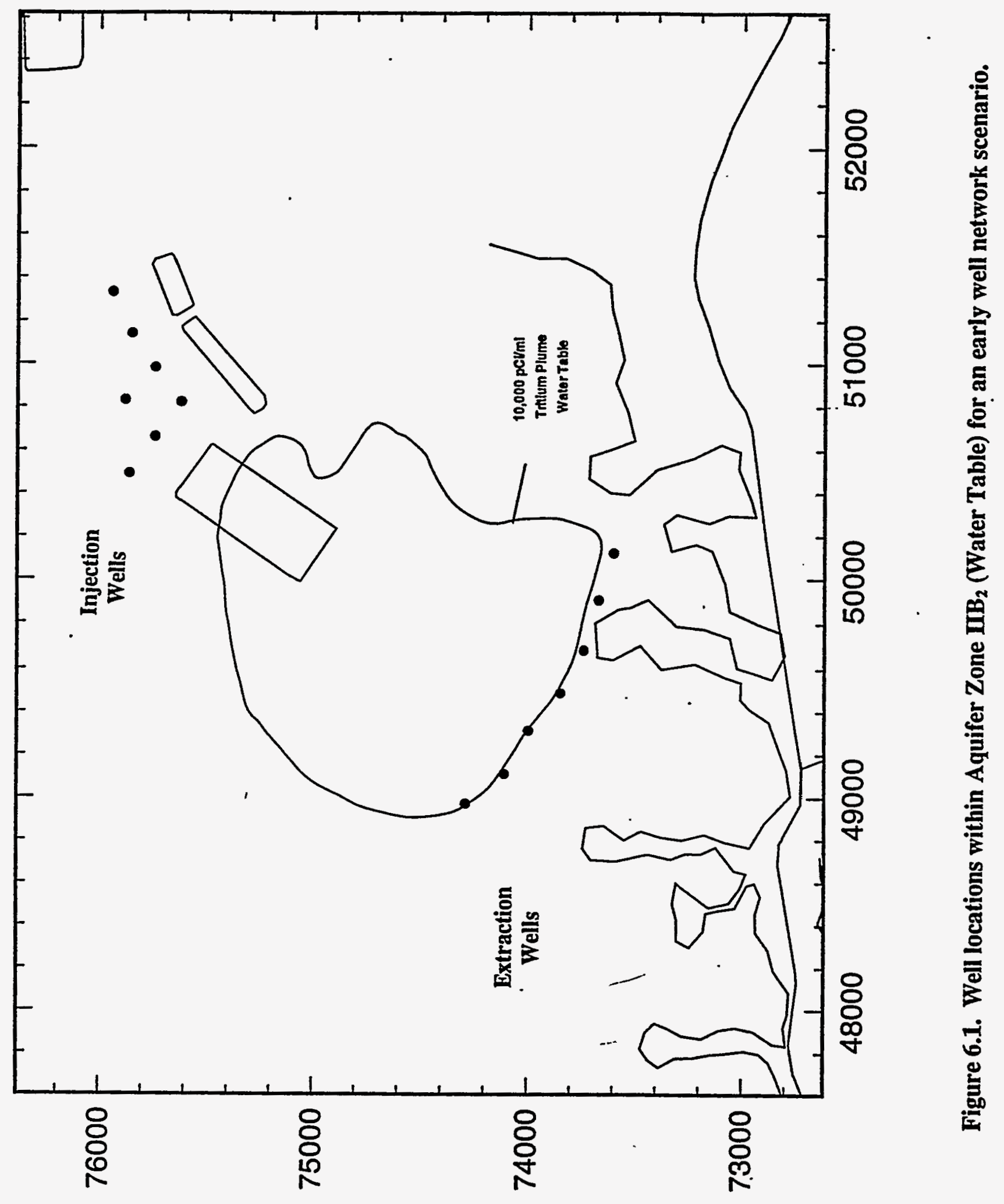




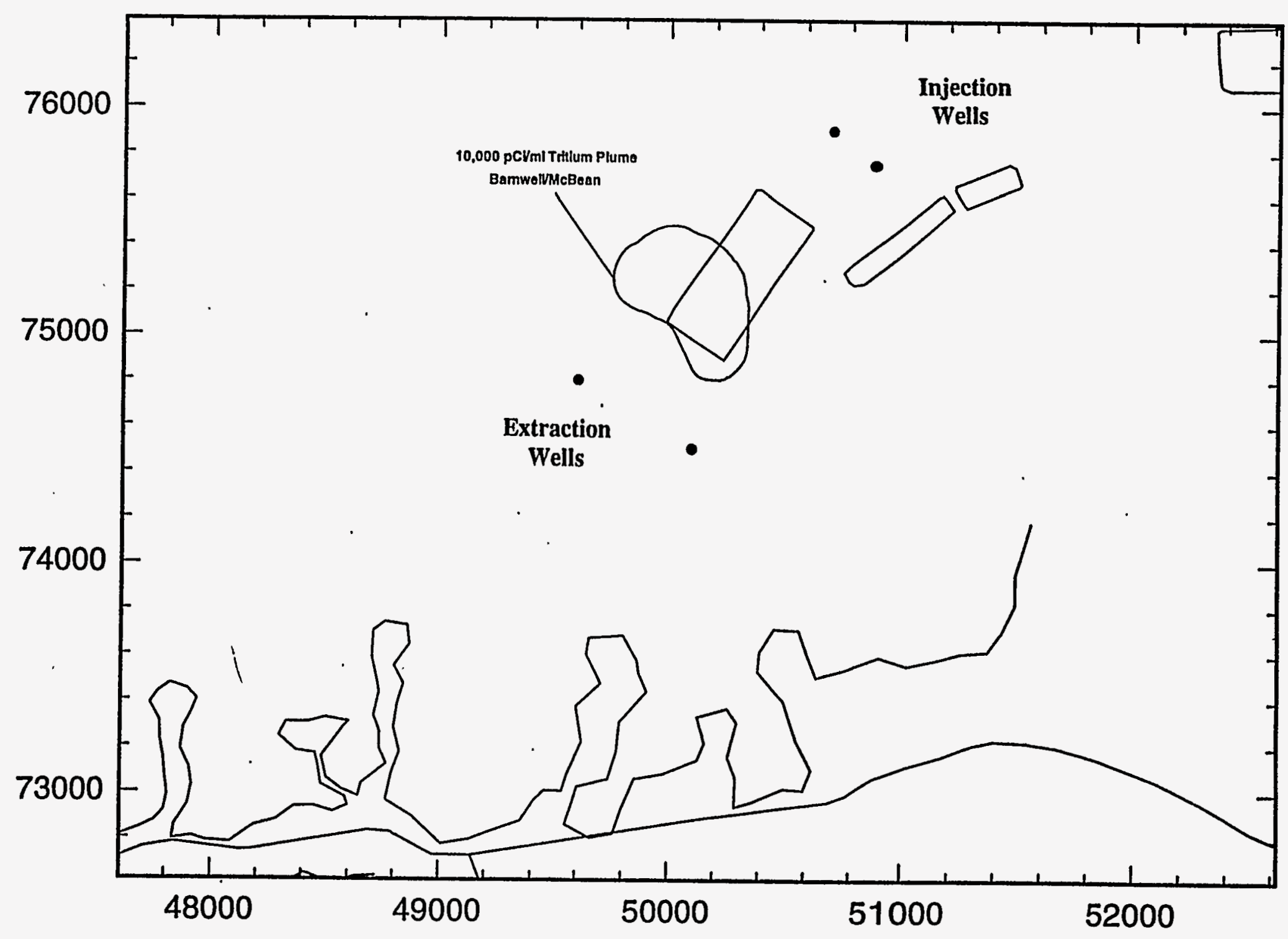

Figure 6.2. Well locations within Aquifer Zone $\mathrm{IB}_{1}$ (Barnwell/McBean) for an early well network scenario.

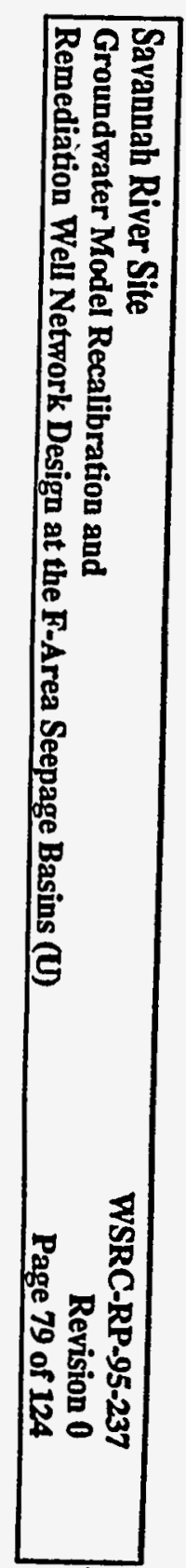




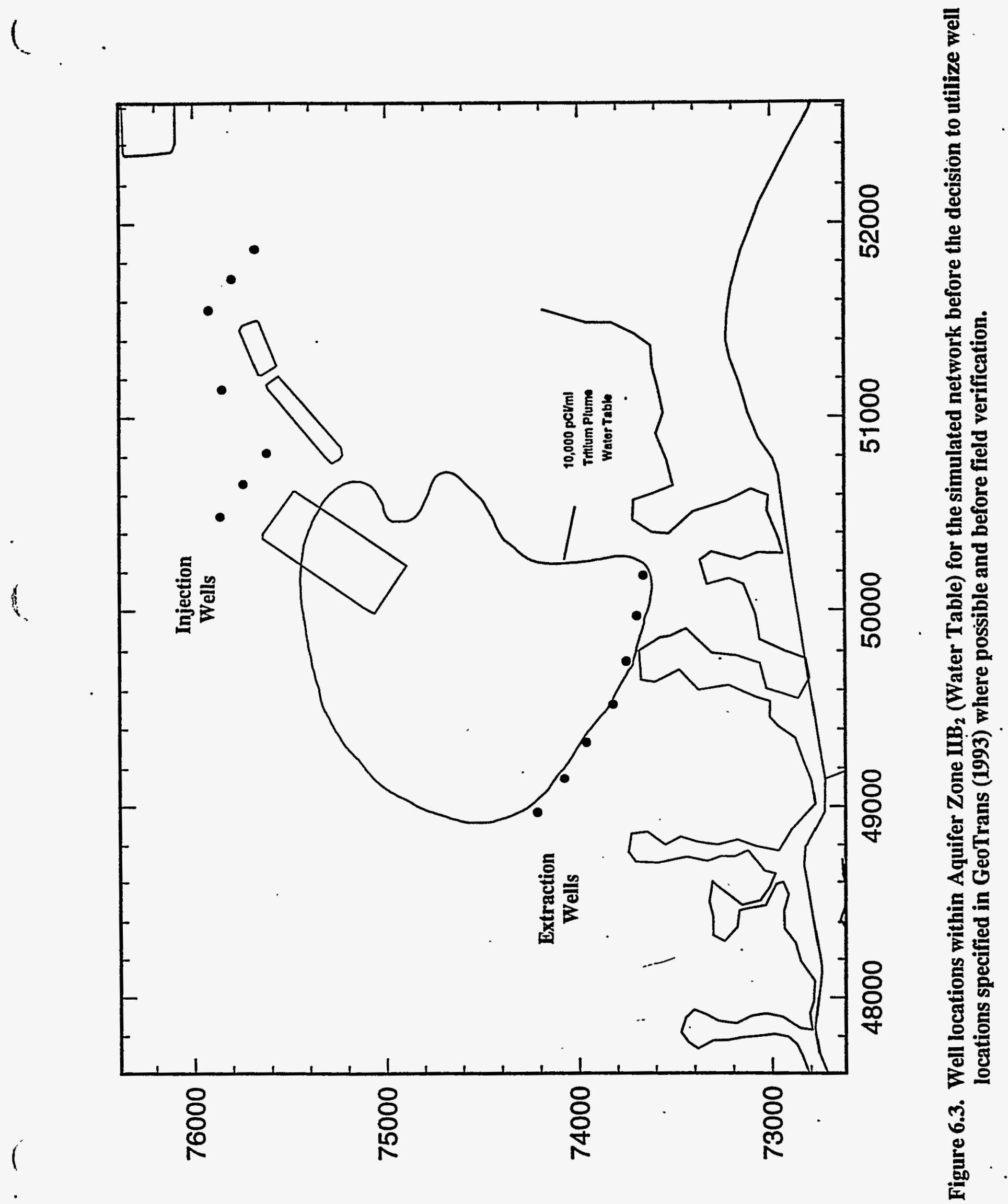




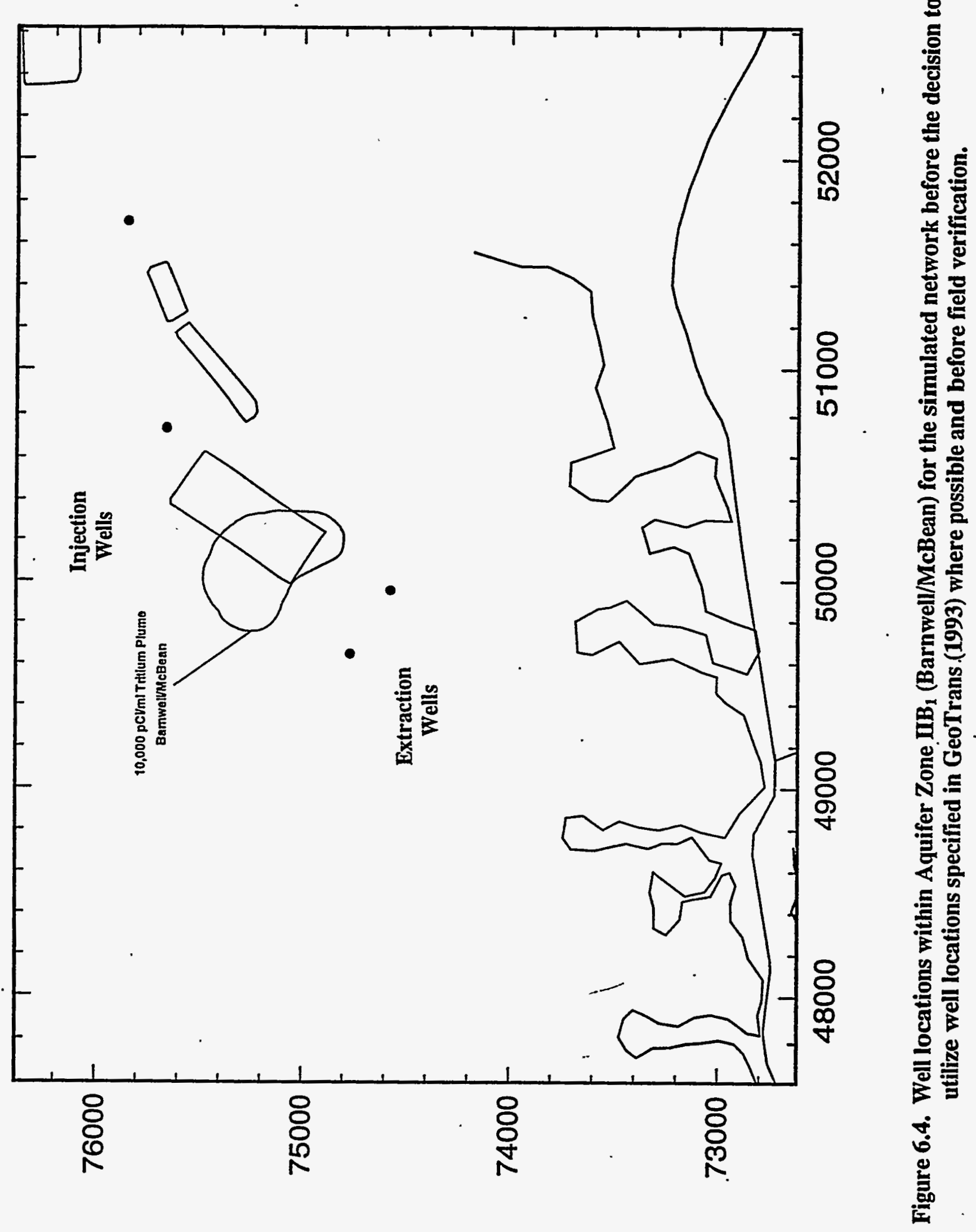



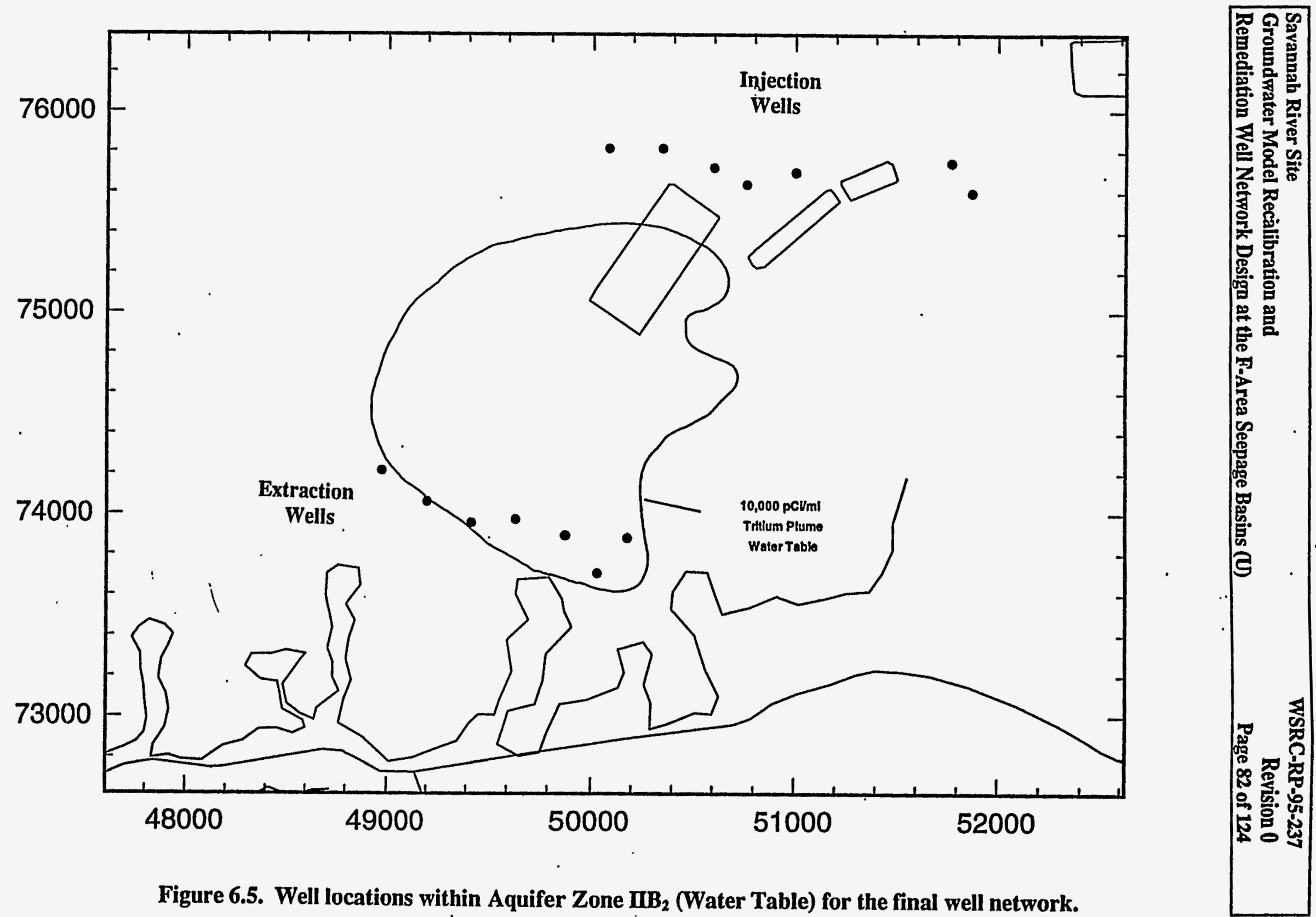

Figure 6.5. Well locations within Aquifer $Z$ one $\mathrm{IB}_{2}$ (Water Table) for the final well network. 

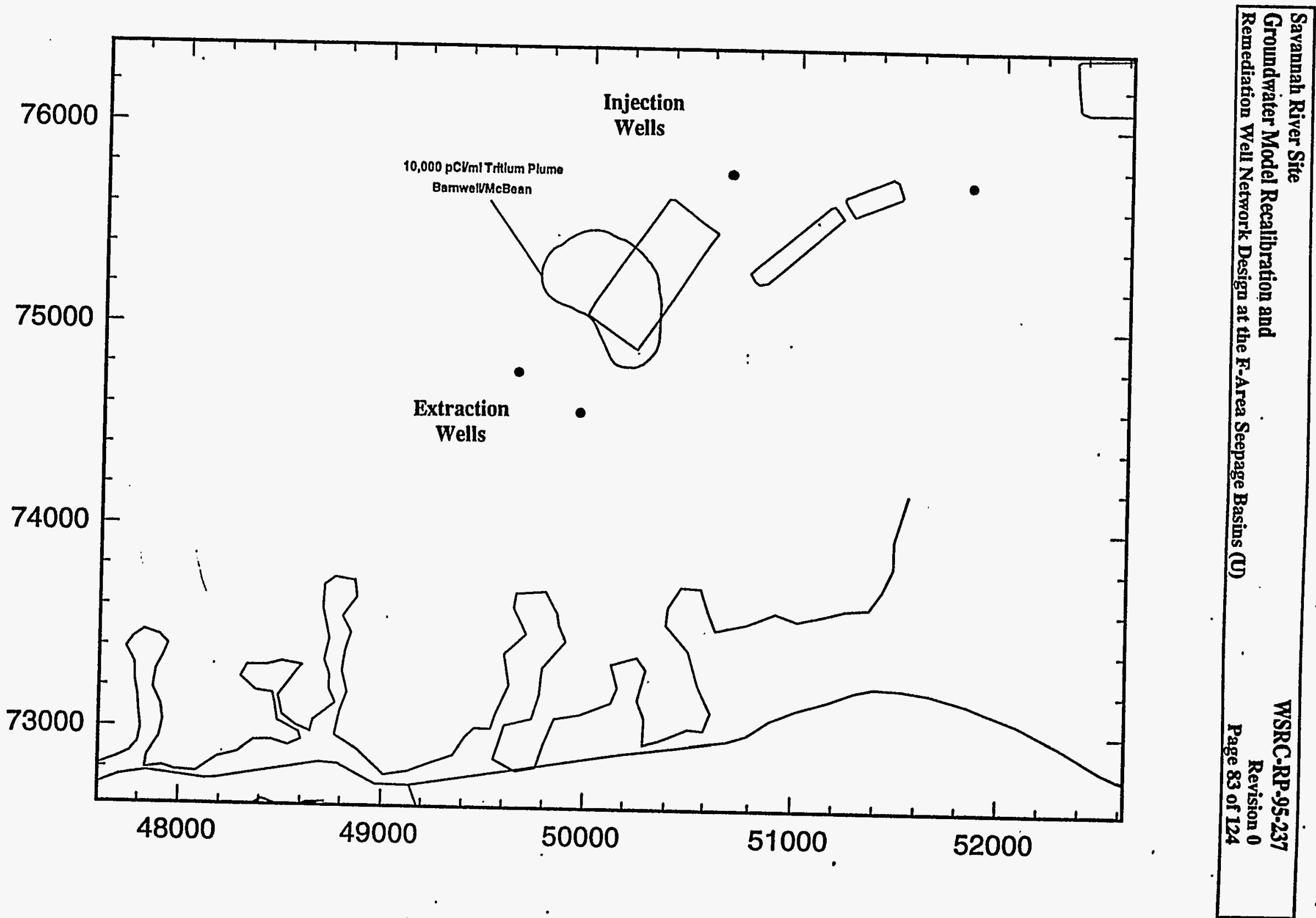

Figure 6.6. Well locations within Aquifer $\mathrm{Zone} \mathrm{HB}_{1}$ (Barnwell/McBean) for the final well network. 
Savannah River Site

Groundwater Model Recalibration and

WSRC-RP-95-237

Remediation Well Network Design at the F-Area Seepage Basins (U)

- Revision 0

Page 84 of 124

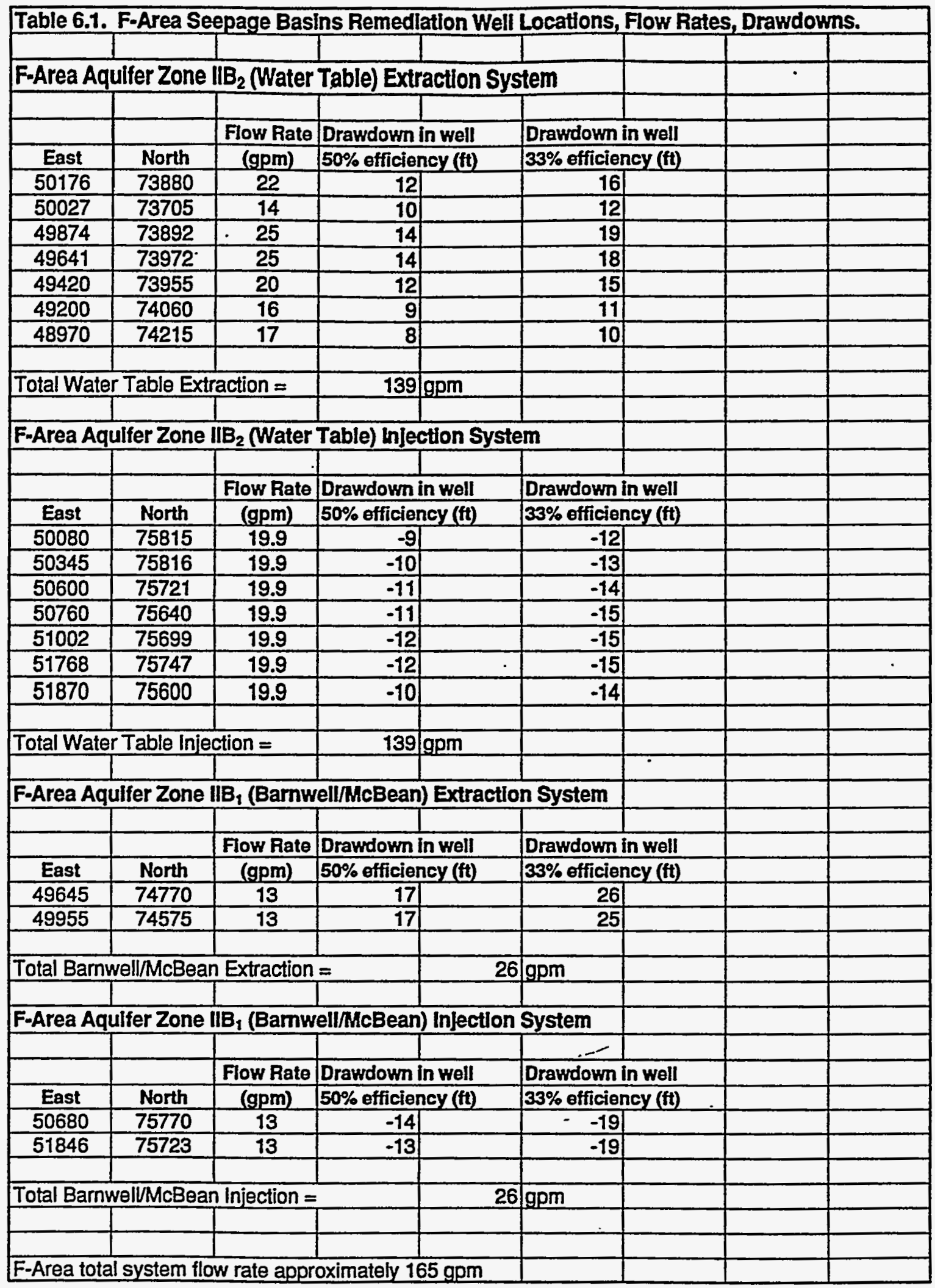




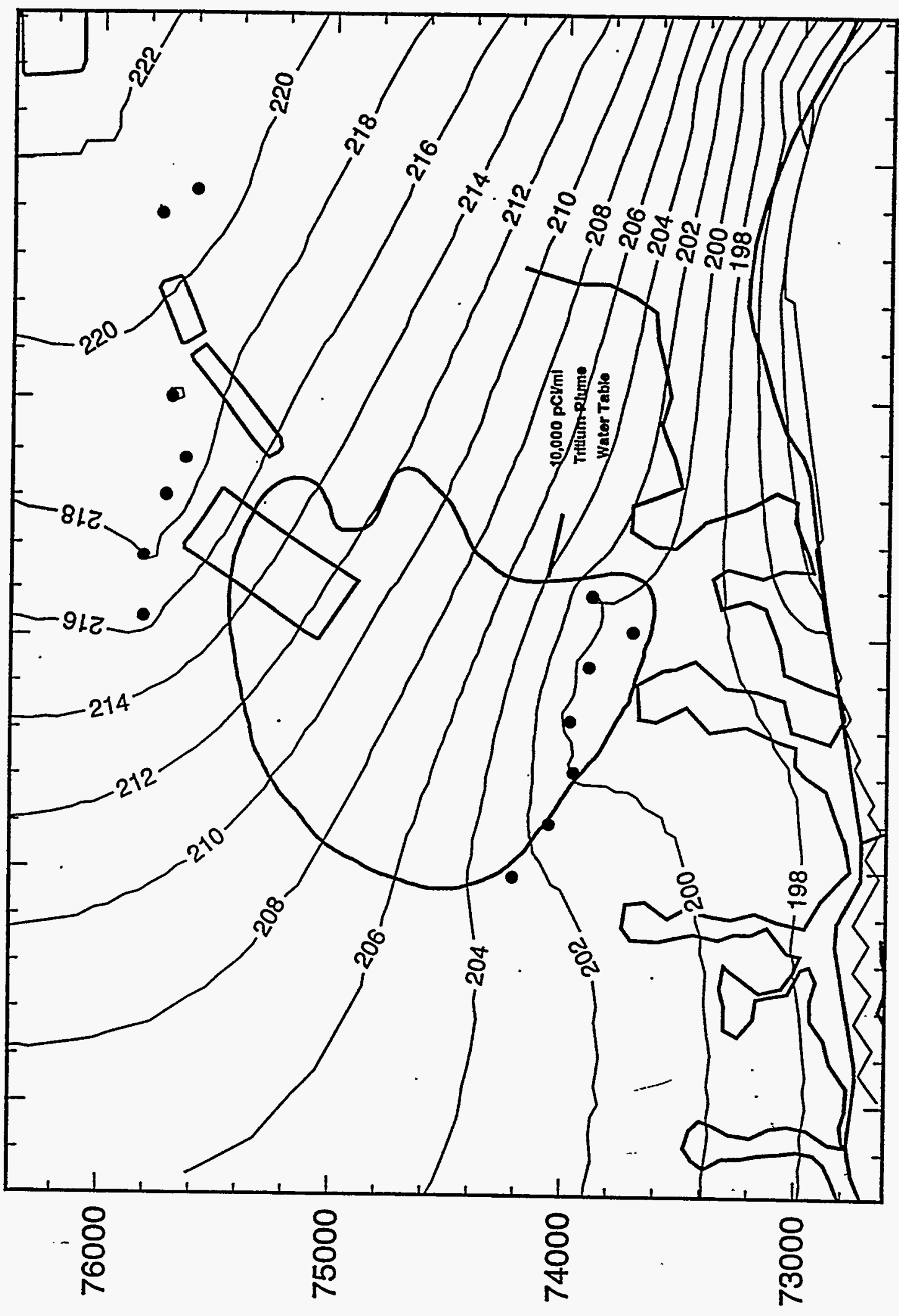




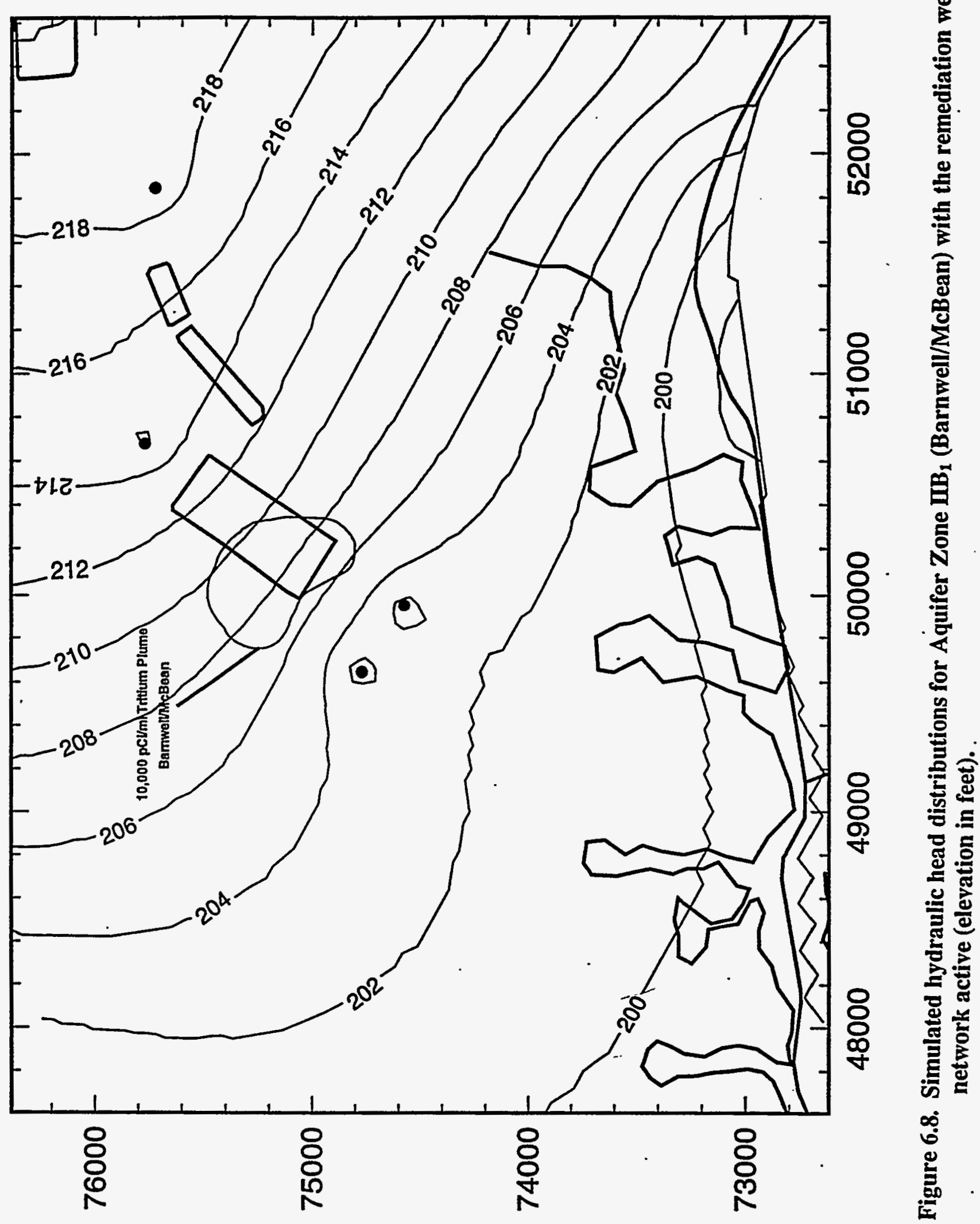




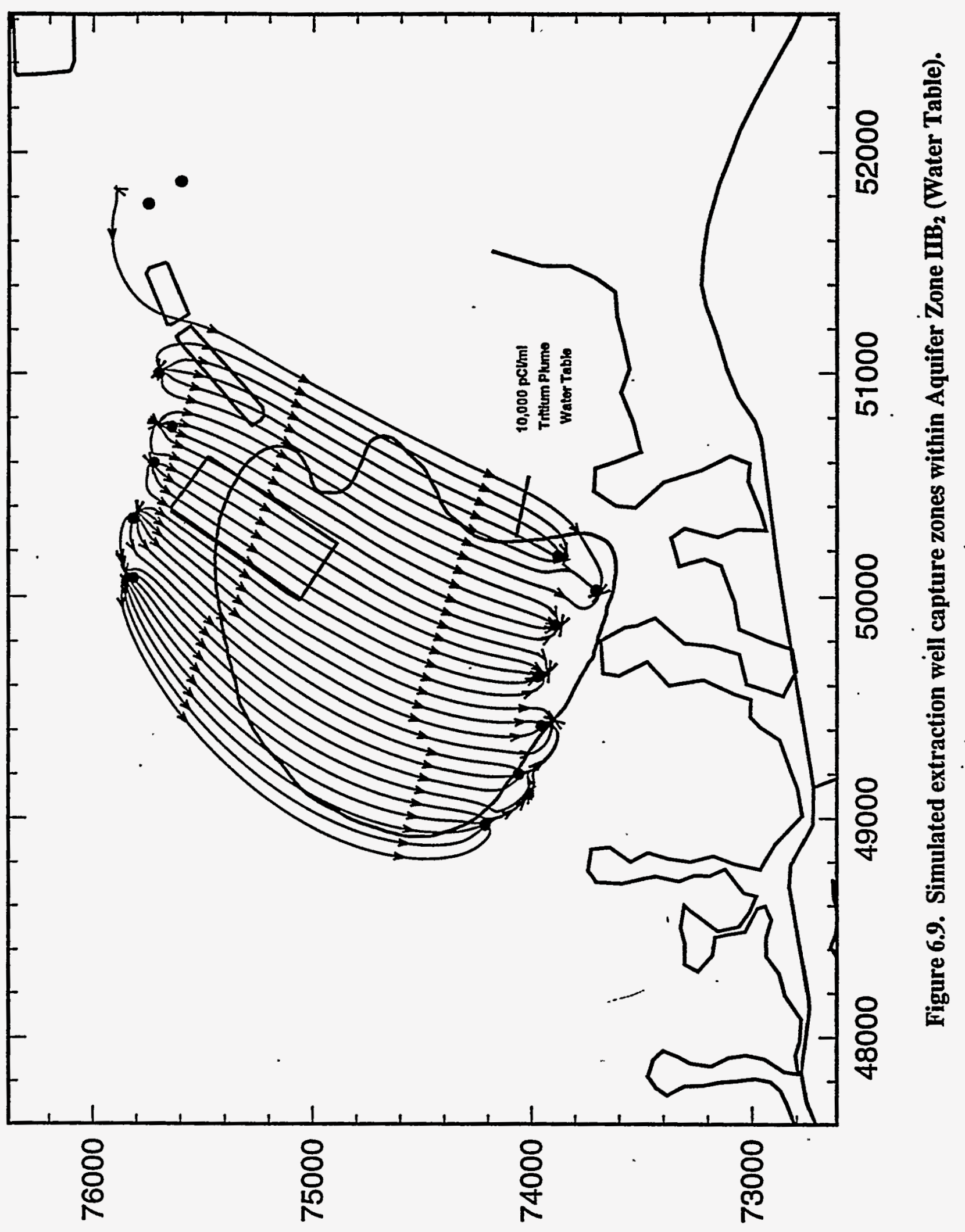




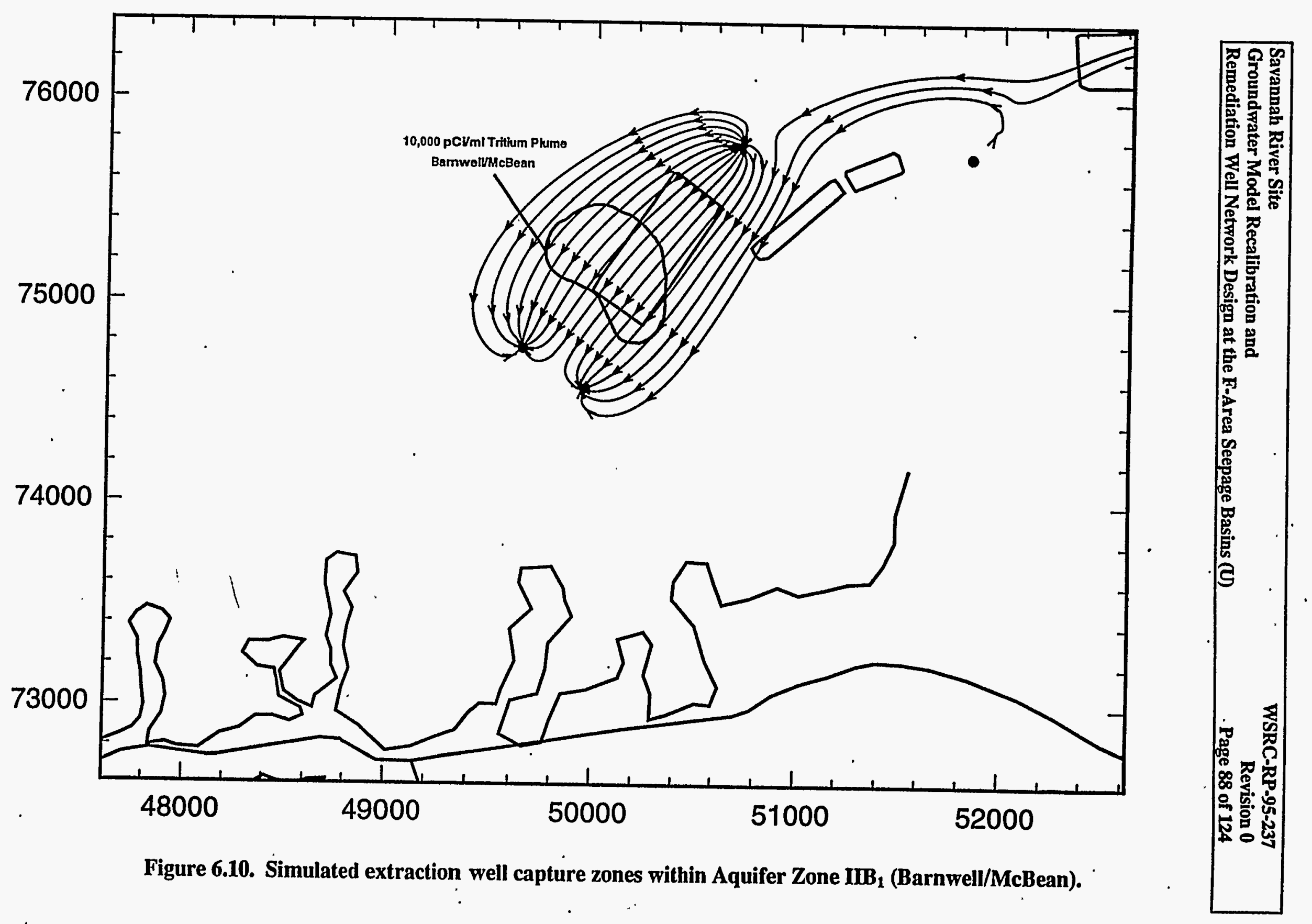




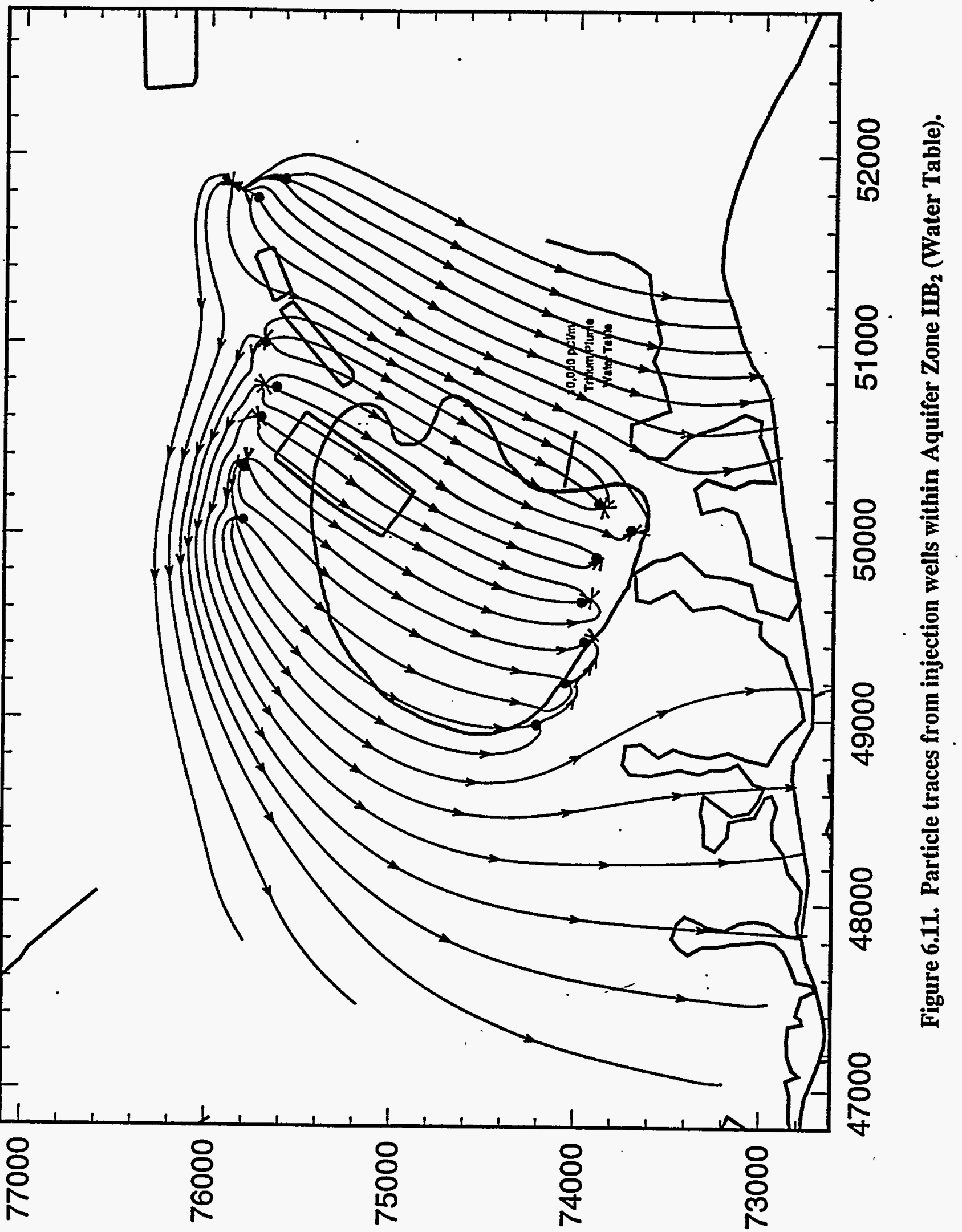




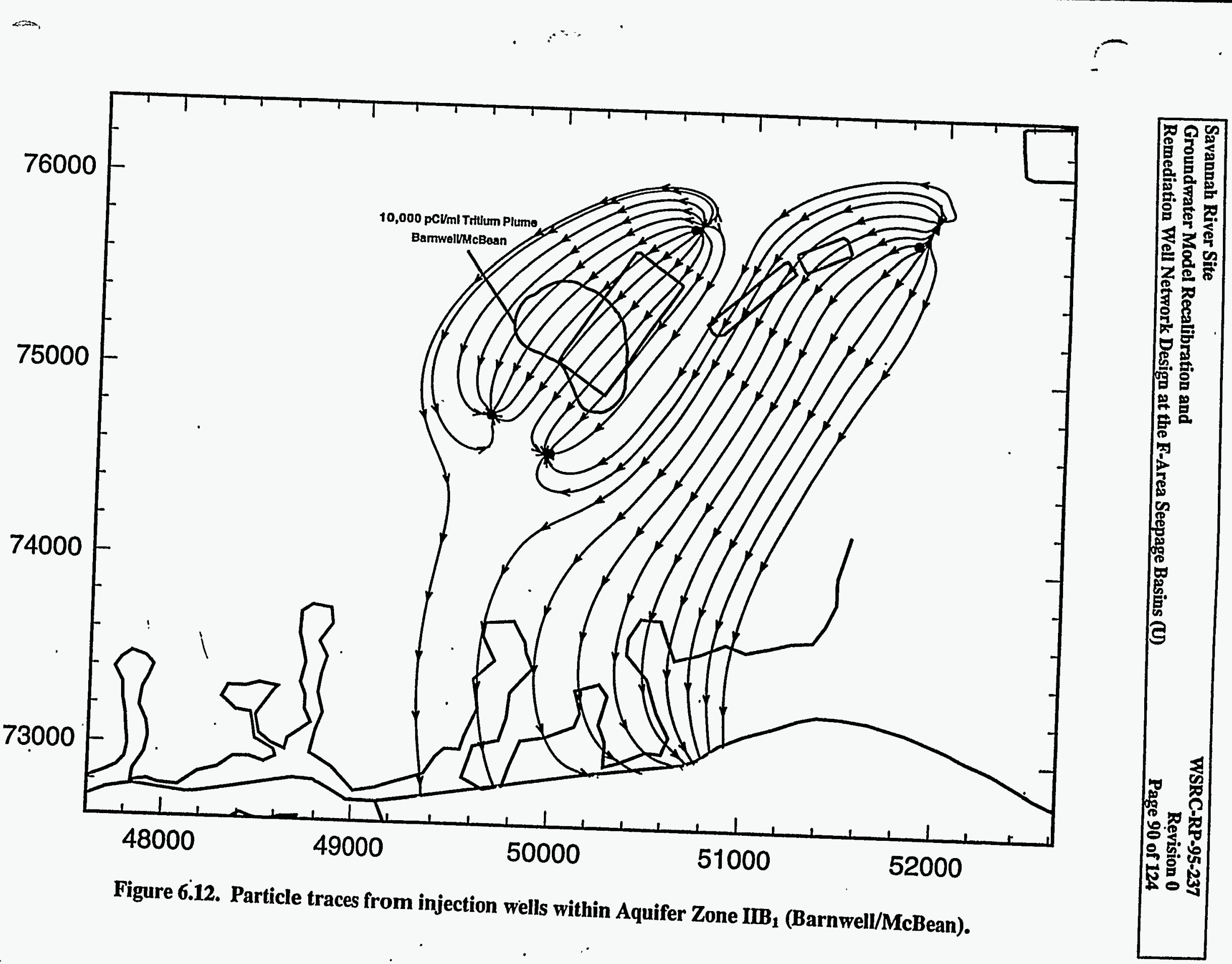




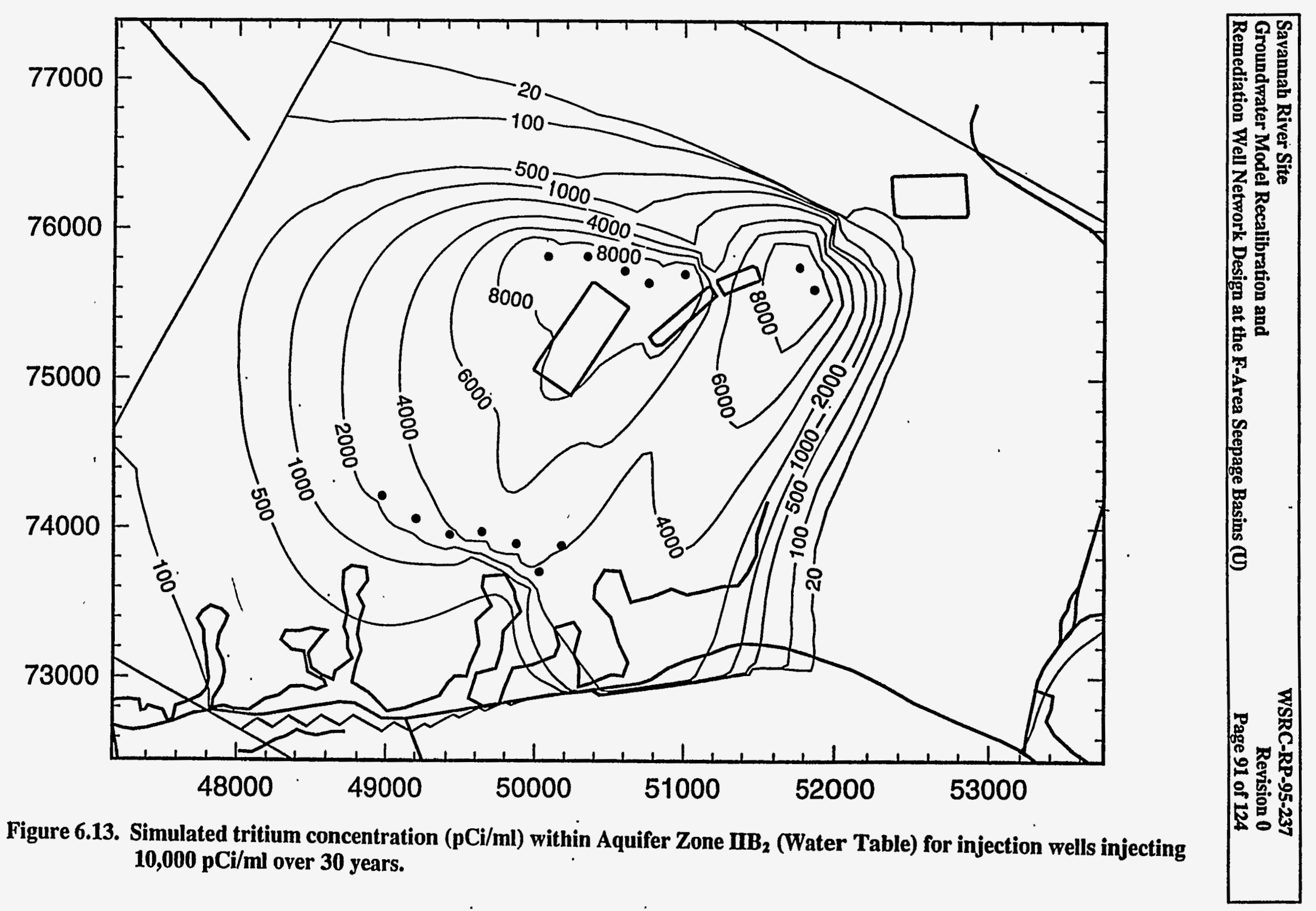




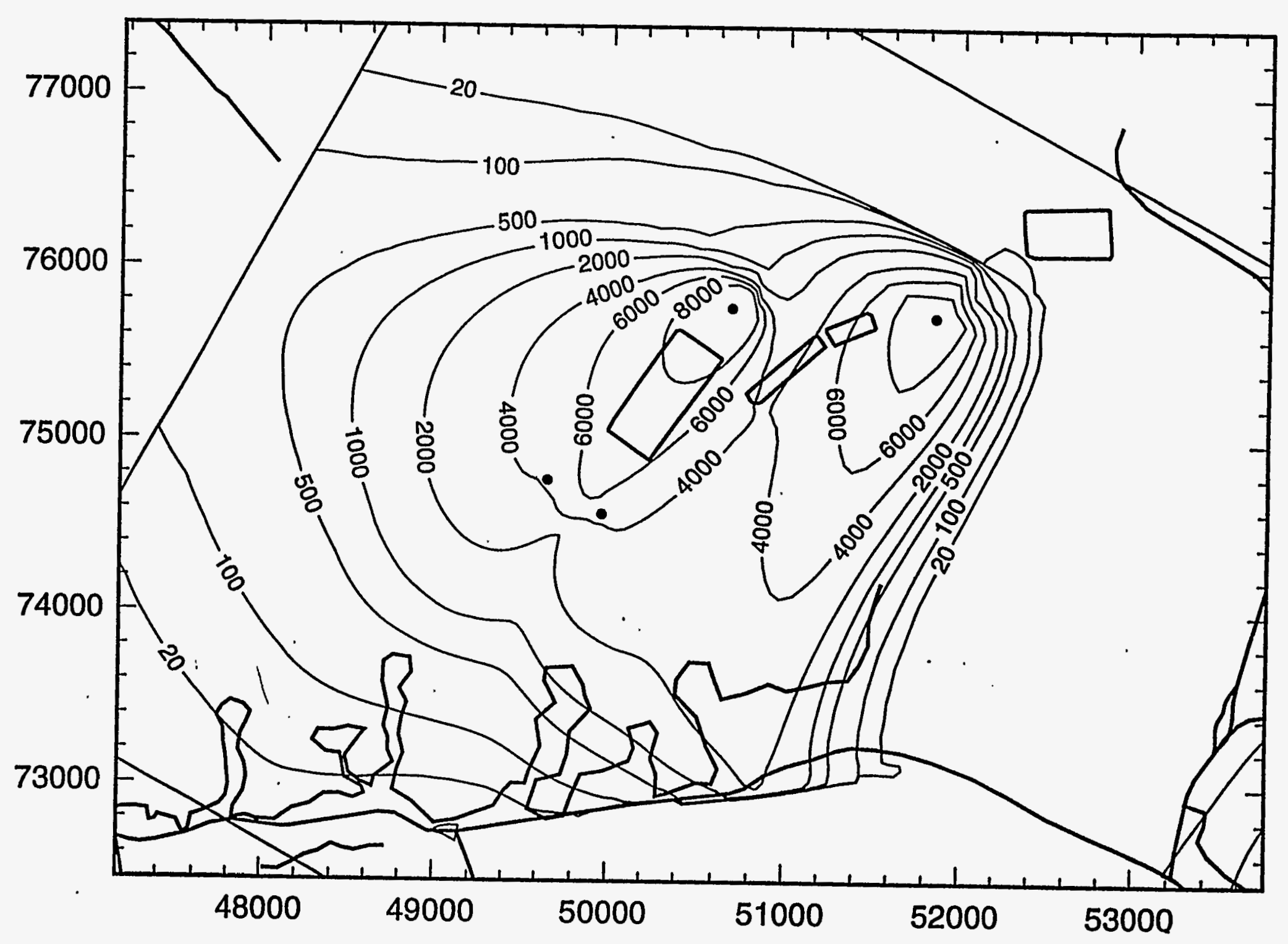

Figure 6.14. Simulated tritium concentration (pCi/ml) within Aquifer Zone $\mathrm{IB}_{1}$ (Barnwell/McBean) for the injection wells injecting $10,000 \mathrm{pCi} / \mathrm{ml}$ over 30 years. 


\subsection{RECOMMENDATIONS FOR FURTHER MODELING EFFORTS}

The F\&H Area Seepage Basins Groundwater Remediation Project Phase I is scheduled to startup in 1997. Later phases have been projected, and the total project may be in operation for 30 years. An updated groundwater model should be used throughout the project to help answer questions about 1) plume capture, 2) recirculation times and percentages, 3) water quality trends, 3) extraction/injection system changes, 4) development of additional phases, etc. The model would be updated, as warranted from the collection of data over time. Updates over the next four years would be after: A) an aquifer testing program which is currently under way, B) after the installation of the extraction and injection project wells, and $\mathrm{C}$ ) after the system has been operational for a period of time.

The current suggestions for future modeling efforts for the F-Area Seepage Basins are:

1) the incorporation of the recent aquifer test results from FSB-OPC in the F-Area Aquifer Zone $\mathrm{IIB}_{1}$ (Barnwell/McBean) as discussed in Section 4.1. This test indicates a zone of lower hydraulic conductivity within this aquifer zone; and is further substantiated by the contaminant distribution within this zone.

2) the division of Layer 2, Aquifer Zone $\mathrm{IBB}_{1}$ (Barnwell/McBean) into at least two layers. The division is needed due to the combination of large thickness, high stratification, observation point: locations, and stream/aquifer interaction for this aquifer zone (Section 4.2.2).

3) if historical contaminant transport is to be simulated, the revision of wastewater source input to Aquifer Zone $\mathbb{I B}_{2}$ (Water Table) should be revised. The revision would include a time lapse between wastewater discharge to the basins and the addition of the wastewater to the aquifer zone (Section 5.2).

4) development of a consistent method for simulating Confining Unit IIB1-IIB2 (Tan Clay)

which accounts for the variations in thickness and vertical hydraulic conductivity (Section 4.2.2).

5) collection of needed field parameters to validate the remediation system once it is operational. 


\subsection{REFERENCES}

Aadland, R.K., 1990, Classification of Hydrostratigraphic Units at Savannah River Site, South Carolina, Savannah River Laboratory, WSRC-RP-90-987, Westinghouse Savannah River Company, Aiken, SC.

Anderson, M.P. and W.W. Woessner, 1992, Applied Groundwater Modeling: Simulation of Flow and Advective Transport, Academic Press, Inc., San Diego, California, 381 p.

Boltz, D.R. and M.L. Weimer, 1994a, Software Evaluation for MODPATH, WSRC, K-EVR-G00005.

Boltz, D.R. and M.L. Weimer, 1994b, Software Quality Assurance Plan for MODPATH, WSRC, K-SQP-G-00029.

Boltz, D.R. and M.L. Weimer, 1994c, Software Validation Report for MODPATH, WSRC, KSVR-G-00003.

C.T. Main, Inc., 1990, F-Area Aquifer Pump Test Report, October 22, 1990.

Daniel, R., 1991, Estimation of Hydraulic Conductivity of Aquifer in the F and H Seepage Basin Areas (U), WSRC Inter-Office Memorandum EPD-SE-91-2014:24 to S. Serkiz, contained within Schiefer, et.al. 1993, Pump \& Treat Process Alternatives Study for F- and H- Area . Seepage Basins Groundwater Remediation Project (U), WSRC-RP-92-336, Rev. 1.

Day, G.D., 1995a, Pumping Test Analysis, Well Cluster FSB-PD, Aquifer Zone IIB2, F-Area Seepage Basins, K-ESR-F-00001, Savannah River Site.

Day, G.D., 1995b, Oral and written communication, Senior Hydrogeologist, Bechtel Savannah River Inc., Site Geotechnical Services Department.

Faust, C.R., P.N. Sims, C.P. Spalding, P.F. Andersen, B.H. Lester, M.G. Shupe, A. Harrover, 1993, FTWORK: Groundwater Flow and Solute Transport in Three Dimensions, Documentation Version 2.9, GeoTrans, Inc., Sterling, Virginia

Faust, C.R., P.N. Sims, C.P. Spalding, P.F. Andersen, and S.E.Stephenson, 1990, FTWORK: A Three-Dimensional Groundwater Flow and Solute Transport Code, Westinghouse Savannah River Company, WSRC-RP-89-1085.

Freeze, R.A. and J. A. Cherry, 1979, Groundwater, Prentice-Hall, 604 p.

GeoTrans, Inc., 1993, Groundwater Model Calibration and Review of Remedial Alternatives at the F- and H-Area Seepage Basins, prepared for Westinghouse Savannah River Company, WSRC-TR-93-384. 
GeoTrans, Inc., 1990a, Preliminary Evaluation of Remedial Alternatives for the F-Area Seepage Basins.

GeoTrans, Inc., 1990b, Preliminary Evaluation of Remedial Alternatives for the H-Area Seepage Basins.

GeoTrans, Inc., 1991, Groundwater Modeling of Remedial Alternatives for the F- and H-Area Seepage Basins, prepared for Westinghouse Savannah River Company.

Hamm, L.L., 1995, Software Management for the FTWORK Package. (L18.20 \& 5.1), SRT-ESS-95-197.

Kruseman, G.P. and N.A. de Ridder, 1990, Analysis and Evaluation of Pumping Test Data, 2nd Edition, Publication 47, International Institute for Land Reclamation and Improvement, Wageningen, The Netherlands.

McMullin, 1993, F- and H-Area Seepage Basins Surface Enhancement: Conceptual Plan, WSRC Inter-Office Memorandum SWE-ERG-930610, July 27, 1993.

Pollock, D.W., 1989, Documentation of Computer Programs to Compute and Display Pathlines using Results from the U. S. Geological Survey Modular Three-Dimensional FiniteDifference Groundwater Flow Model, U.S. Geological Survey Open File Report 89-381.

Reichert, S.O. and J.W. Fenimore, 1962, Lithology and Hydrology of Radioactive Waste Disposal Sites at the Savannah River Plant, Savannah River Plant, E.I. du Pont de Nemours and Company, DPSPU 62-30-21B.

Sadler, W.R., 1993 Interim Report on Hydraulic Conductivity Values Estimated from Three Constant Rate Injection "Tests Near the F-Area and H-Area Seepage Basins (U), Westinghouse Savannah River Company, WSRC-RP-93-1235.

Schappell, B.G. and W.R. Sadler, 1993, Site Geotechnical Services Comments on the May, 1993 Draft Modeling Report by GeoTrans for the F- and H-Area Seepage Basins (U), WSRC Inter-Office Memorandum 400:EPD-SGS-93-0073 to W.W. Pidcoe, June 23, 1993.

Swift, W.F., 1994, RE: Update for the Extraction Test at F-Area Seepage Basins Aquifer Zone IIB1, WSRC Inter-Office Memorandum E\&PD-SGS-94-0452 to J.A. Adams and J.E. Sciarro, November 22, 1994.

Westinghouse Savannah River Company (WSRC), Conduct of Engineering and Technical Support (U), Procedure Manual E7.

Westinghouse Savannah River Company (WSRC), Quality Assurance Manual (U), Procedure Manual 1Q. 
Westinghouse Savannah River Company (WSRC), 1992a, 1992 RCRA Part B Permit Renewal Application (U), Savannah River Site, F-Area Hazardous Waste Management Facility Postclosure, WSRC-IM-91-53.

Westinghouse Savannah River Company (WSRC), 1992a, F- and H-Area Seepage Basins Well Installations for Aquifer Injection Testing, Data Summary (U), Savannah River Site, WSRC-RP-92-896.

Westinghouse Savannah River Company (WSRC), 1991, F-Area Seepage Basins, Second Quarter, 1991, Groundwater Quality Assessment Report (U), WSRC-TR-91-516. 


\section{APPENDIX 1}

\section{COMPARISON OF HYDRAULIC HEAD} FROM REGIONAL AND LOCAL MODEL 
The regional flow model was calibrated to the targets described in Section 3.2. Calibrated parameters, boundary conditions, and interpolated regional heads (provided constant head along north, east, and west boundaries) were input into the local model. The local model was then run. Figures A1.1 and A1.2 present the hydraulic head distributions of the regional and local models with no extraction/injection wells and with caps in place over the basins. The cell area represented by a node in the local model is 20 times less than the area represented by a regional model node. The differences between the local and regional model contours may be due to the discretization differences in the assignment of model boundaries (drains, streams, seepage basin caps, etc.) and discretization differences used by the plotting routine. 


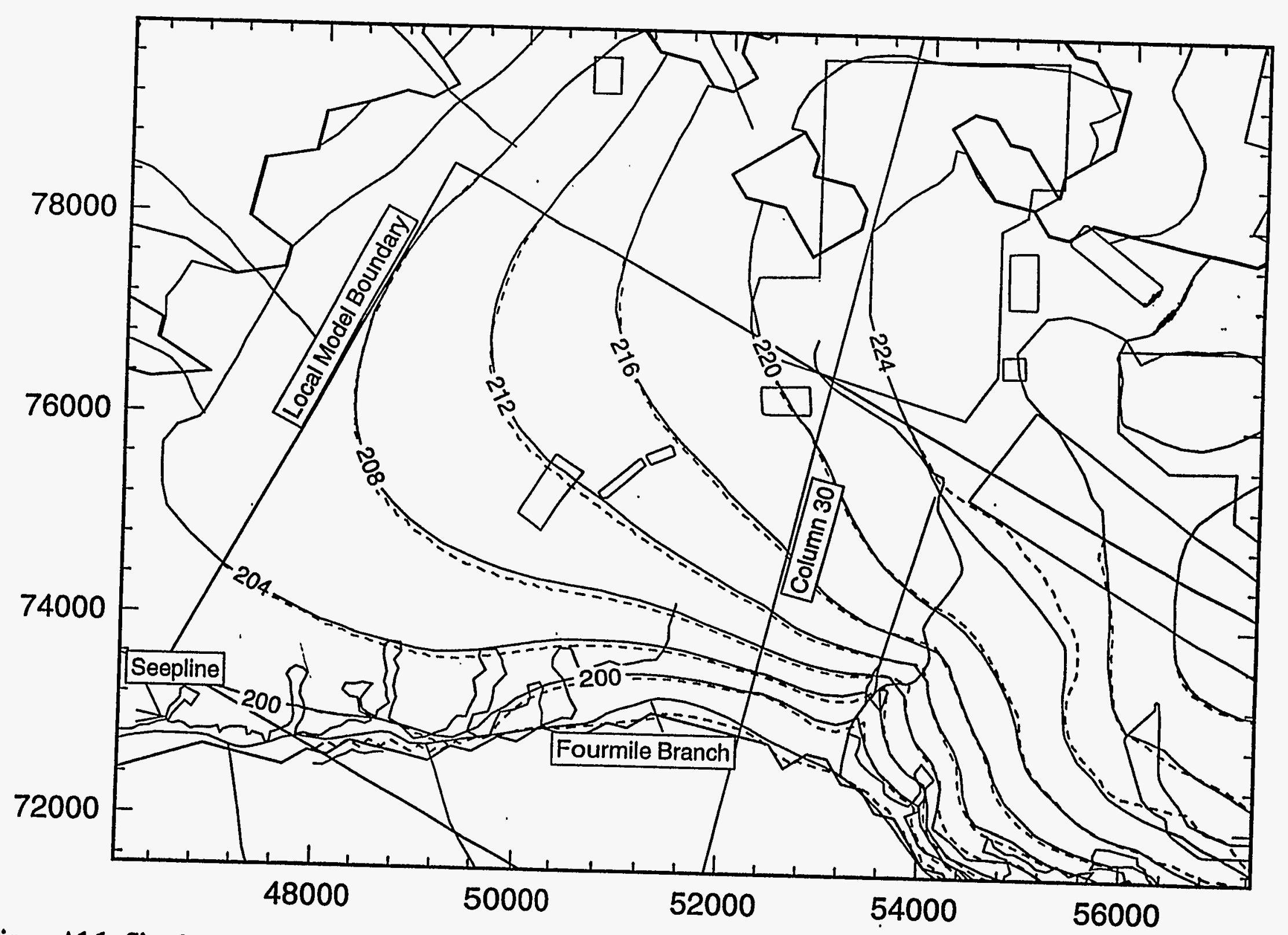
Figure A1.1. Simulated hydraulic head distribution for Aquifer $\mathrm{Zone}_{\mathrm{IB}}$ (Water Table) (elevation in feet) from the regional
and local models. Dashed equipotential lines represent the local model output and solid equipotential lines
represent the regional model output. 


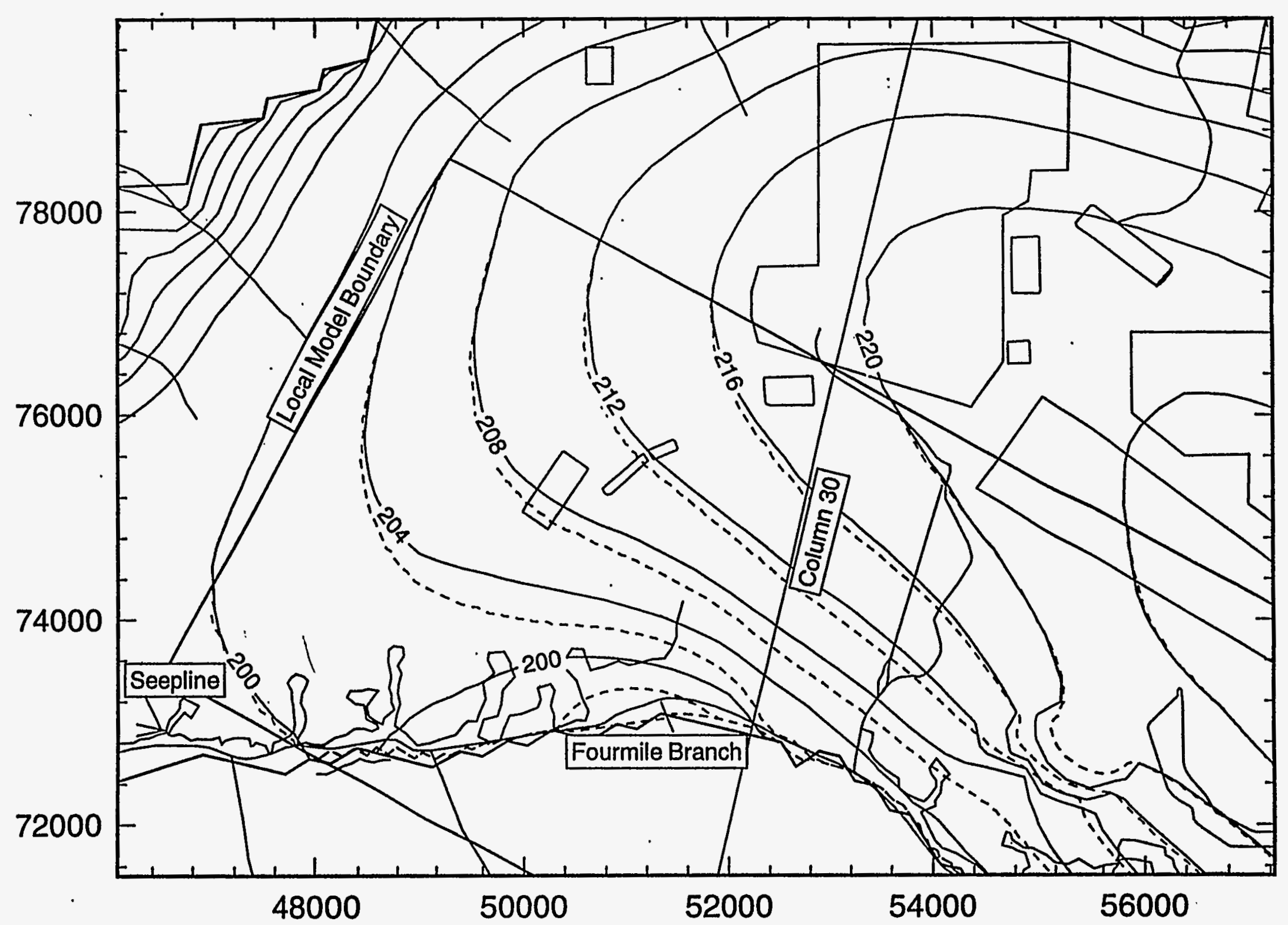

Figure A1.2. Simulated hydraulic head distribution for Aquifer Zone $\mathbf{I B}_{\mathbf{1}}$ (Barnwell/McBean) (elevation in feet) from the regional and local models. Dashed equipotential lines represent the local model output and solid equipotential lines represent the regional model output. 


\section{APPENDIX 2}

CALIBRATION RESULTS FOR TOTAL MODEL AREA 


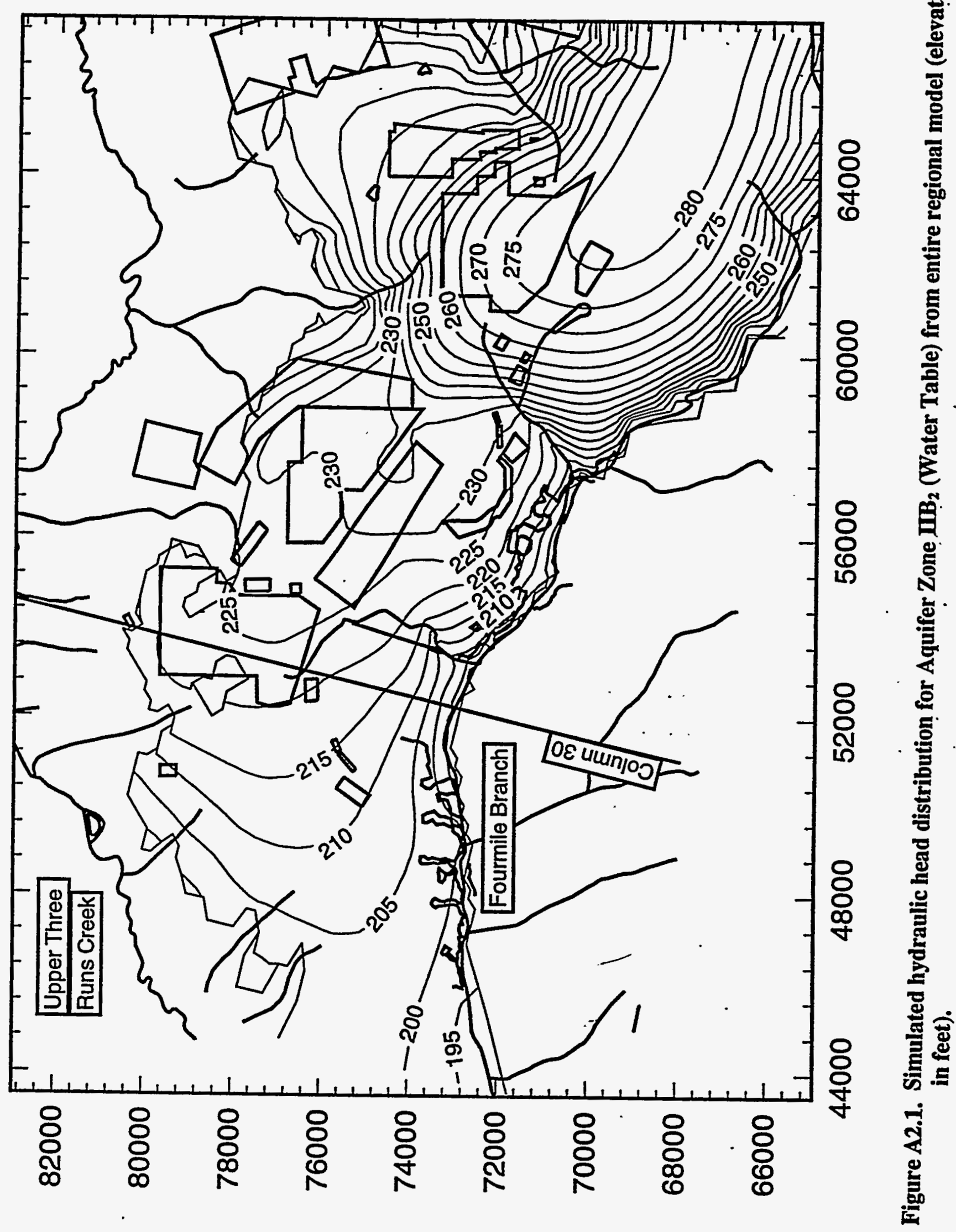




\begin{tabular}{|lr|}
\hline Savannah River Site & WSRC-RP-95-237 \\
Groundwater Model Recalibration and & Revision 0 \\
Remediation Well Network Design at the F-Area Seepage Basins (U) & Page 103 of 124 \\
\hline
\end{tabular}

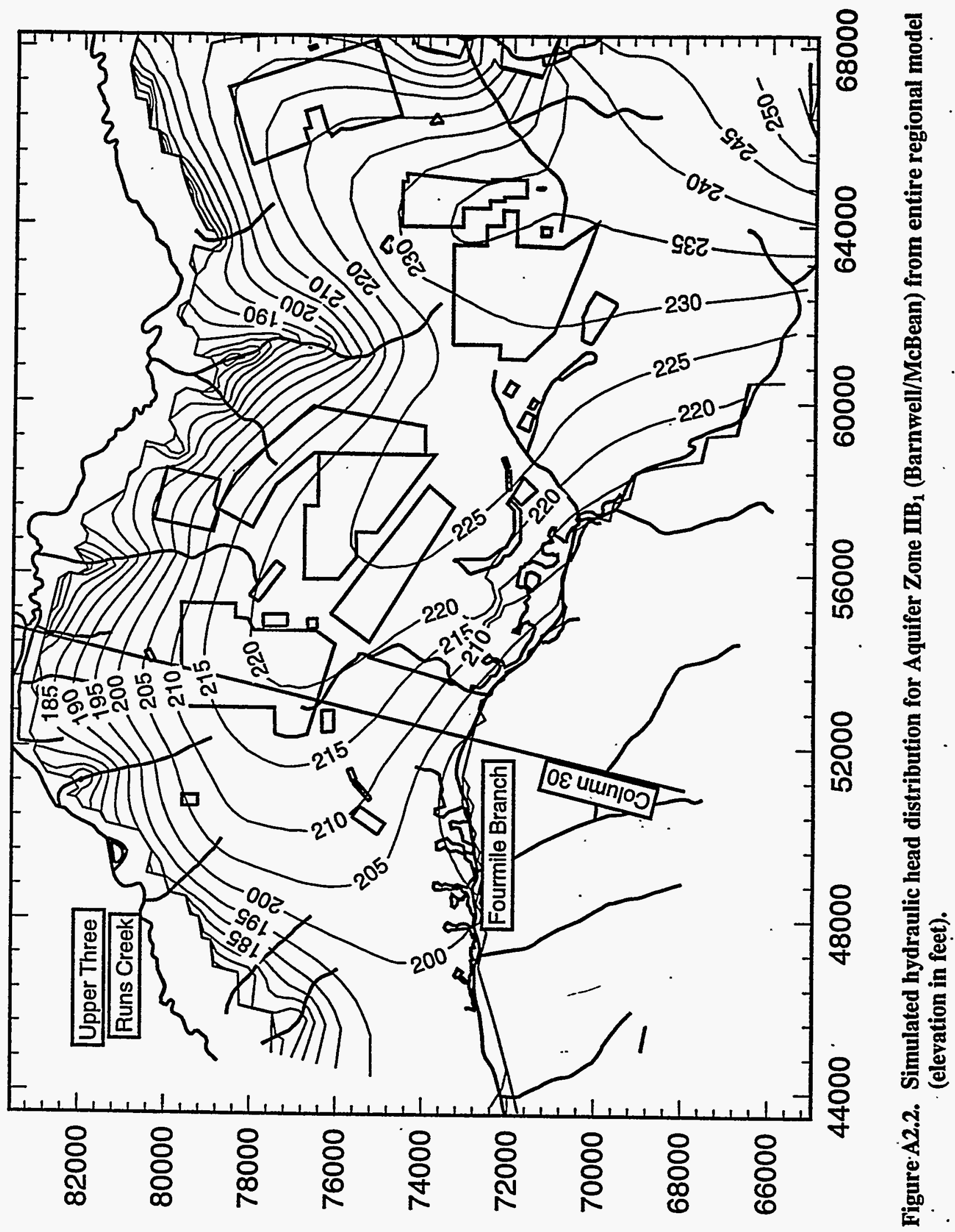


1

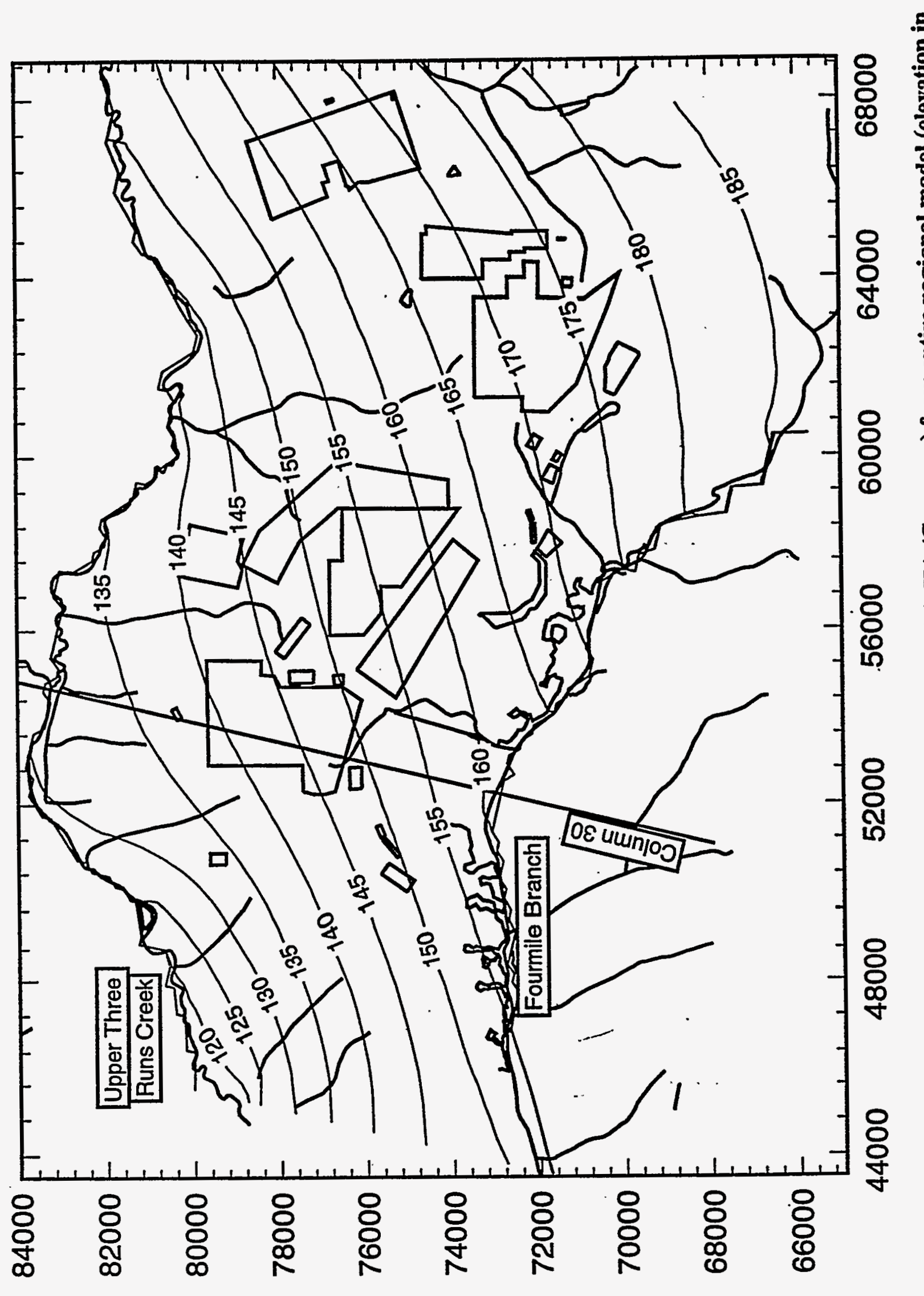

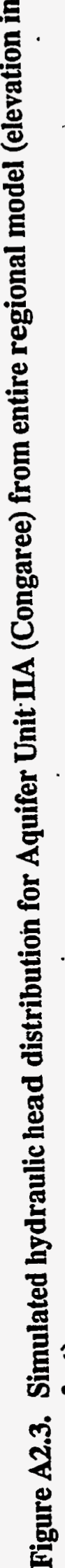




\begin{tabular}{|lr|}
\hline Savannah River Site & WSRC-RP-95-237 \\
Groundwater Model Recalibration and & Revision 0 \\
Remediation Well Network Design at the F-Area Seepage Basins (U) & Page 105 of 124 \\
\hline
\end{tabular}

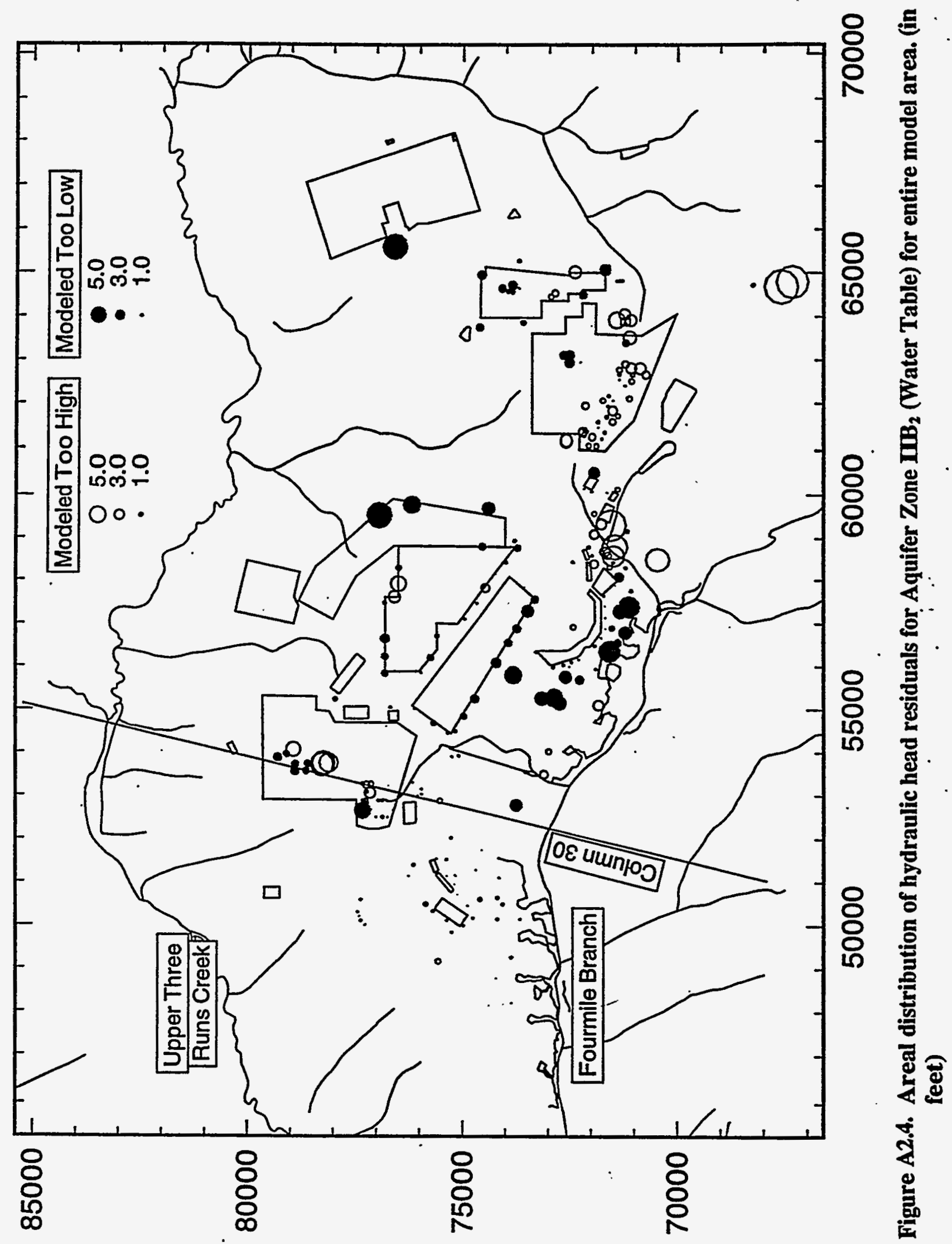




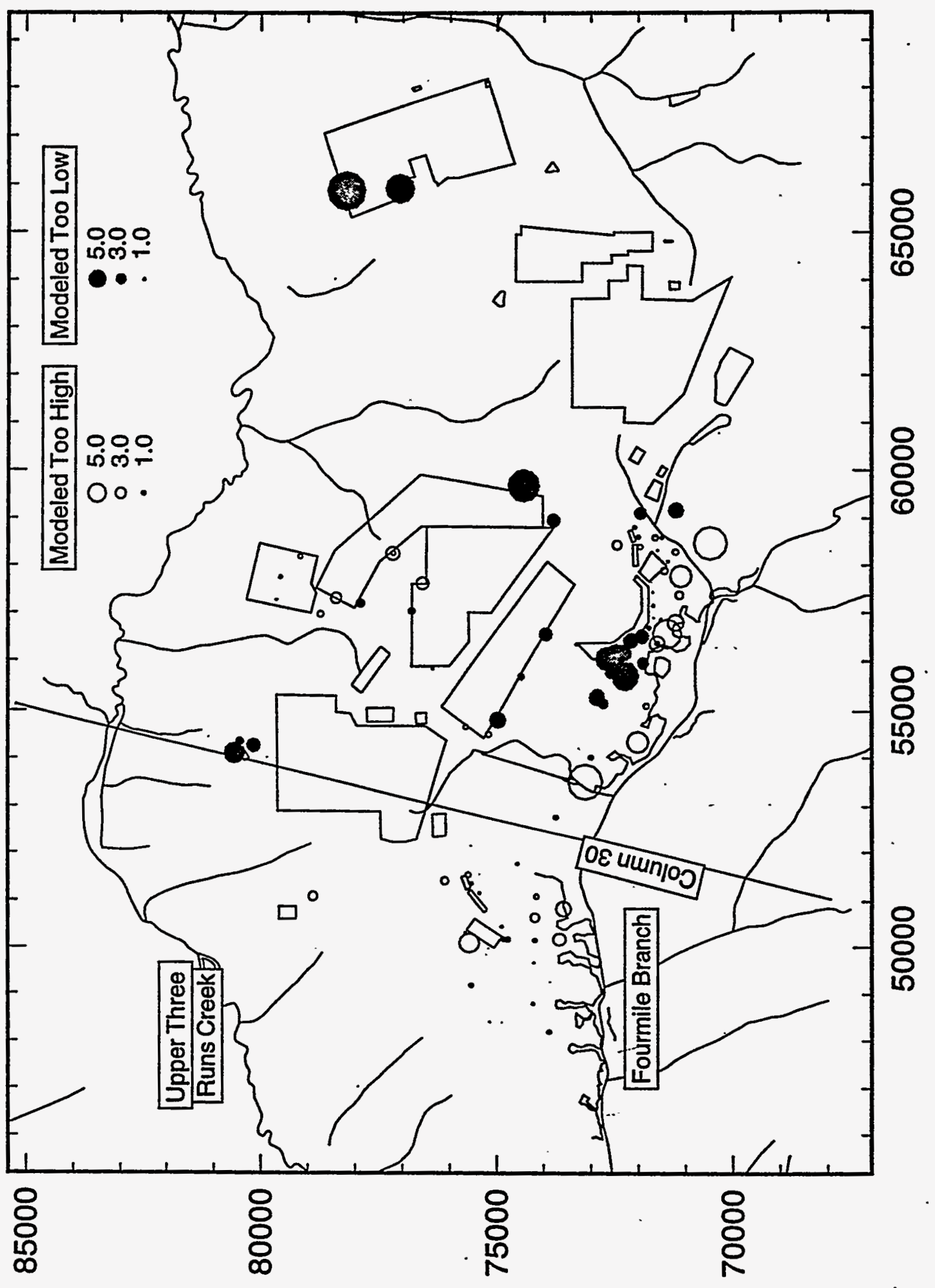




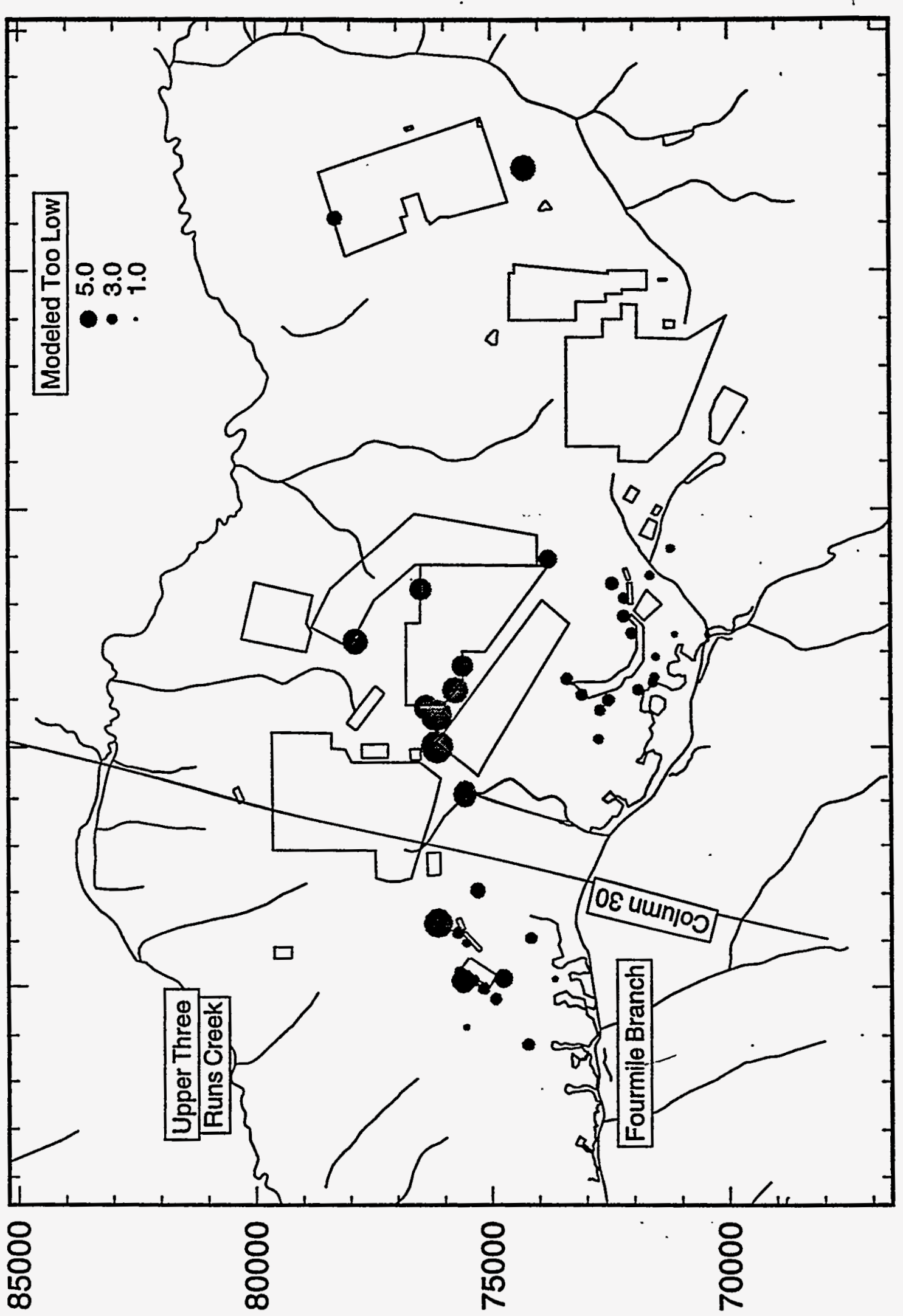

\begin{tabular}{l}
8 \\
8 \\
\hline
\end{tabular}

웡 
?

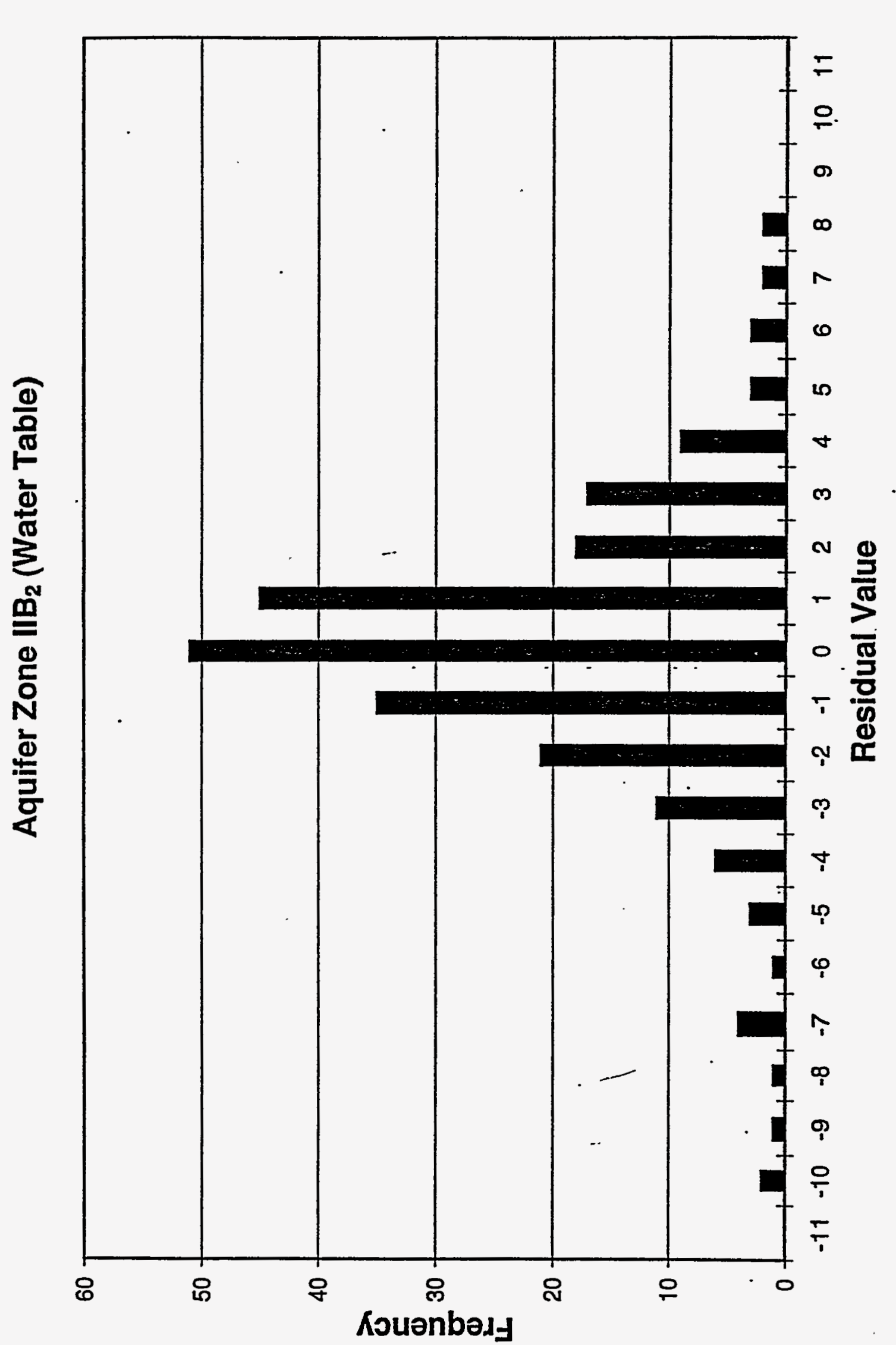

헝 


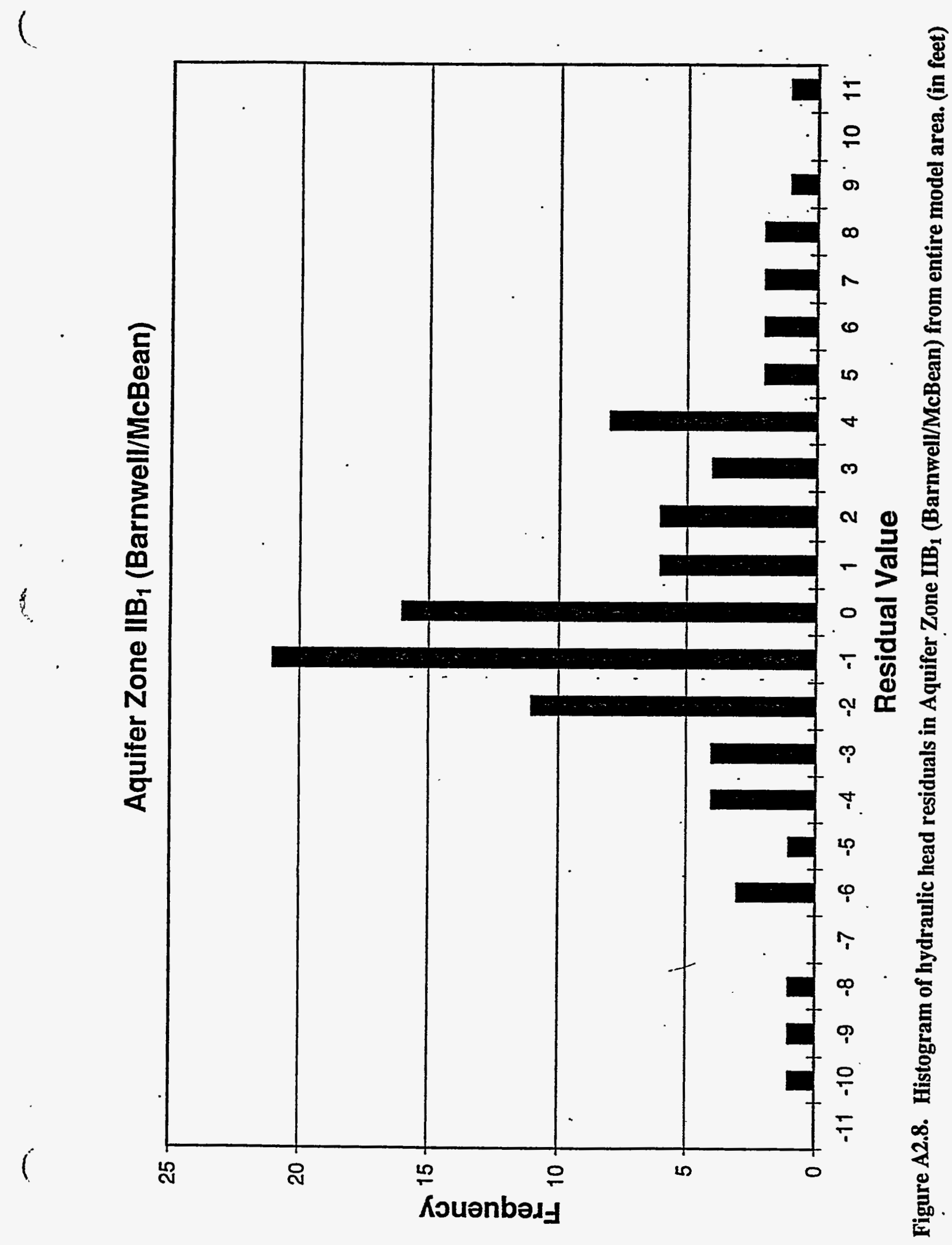




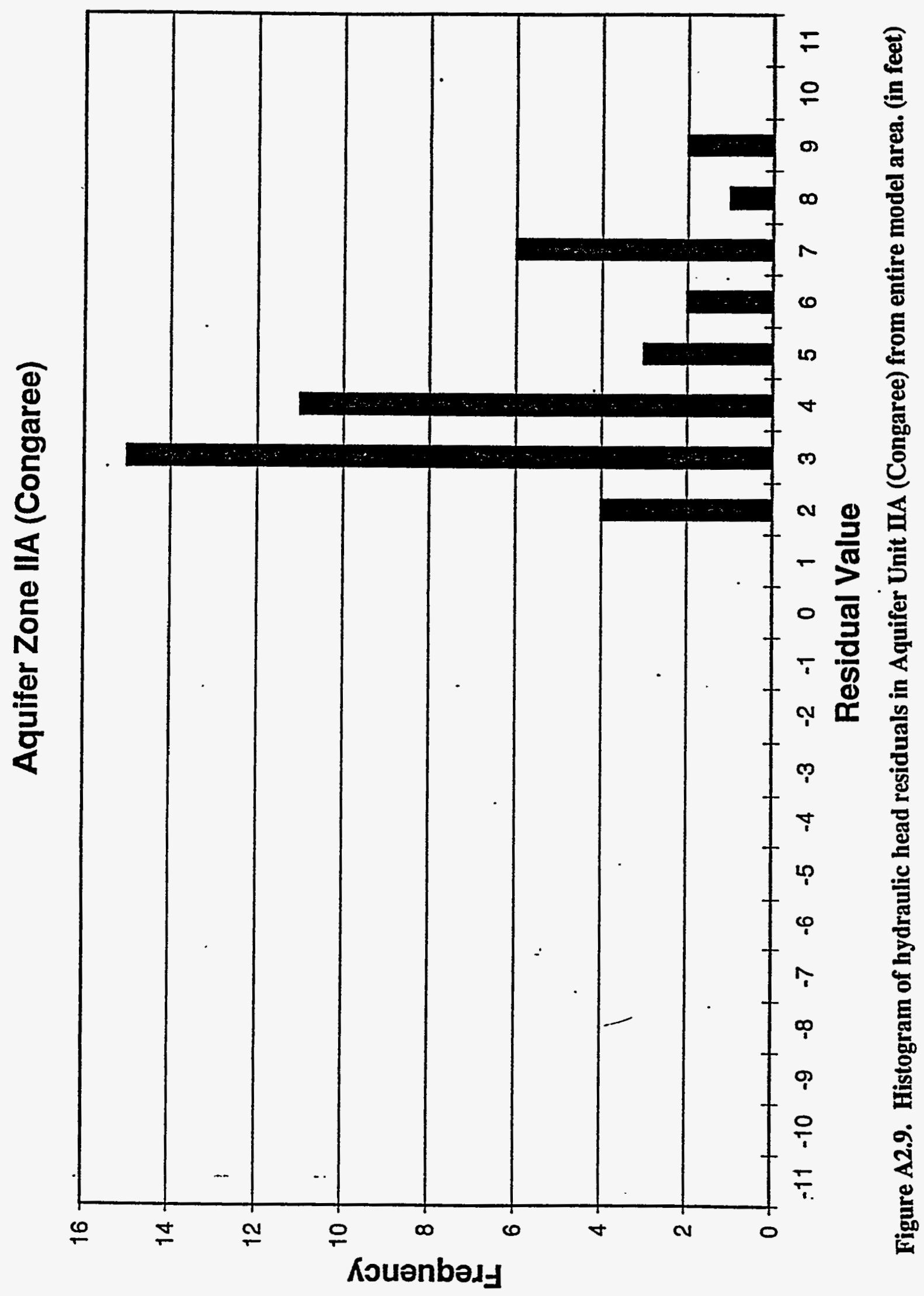




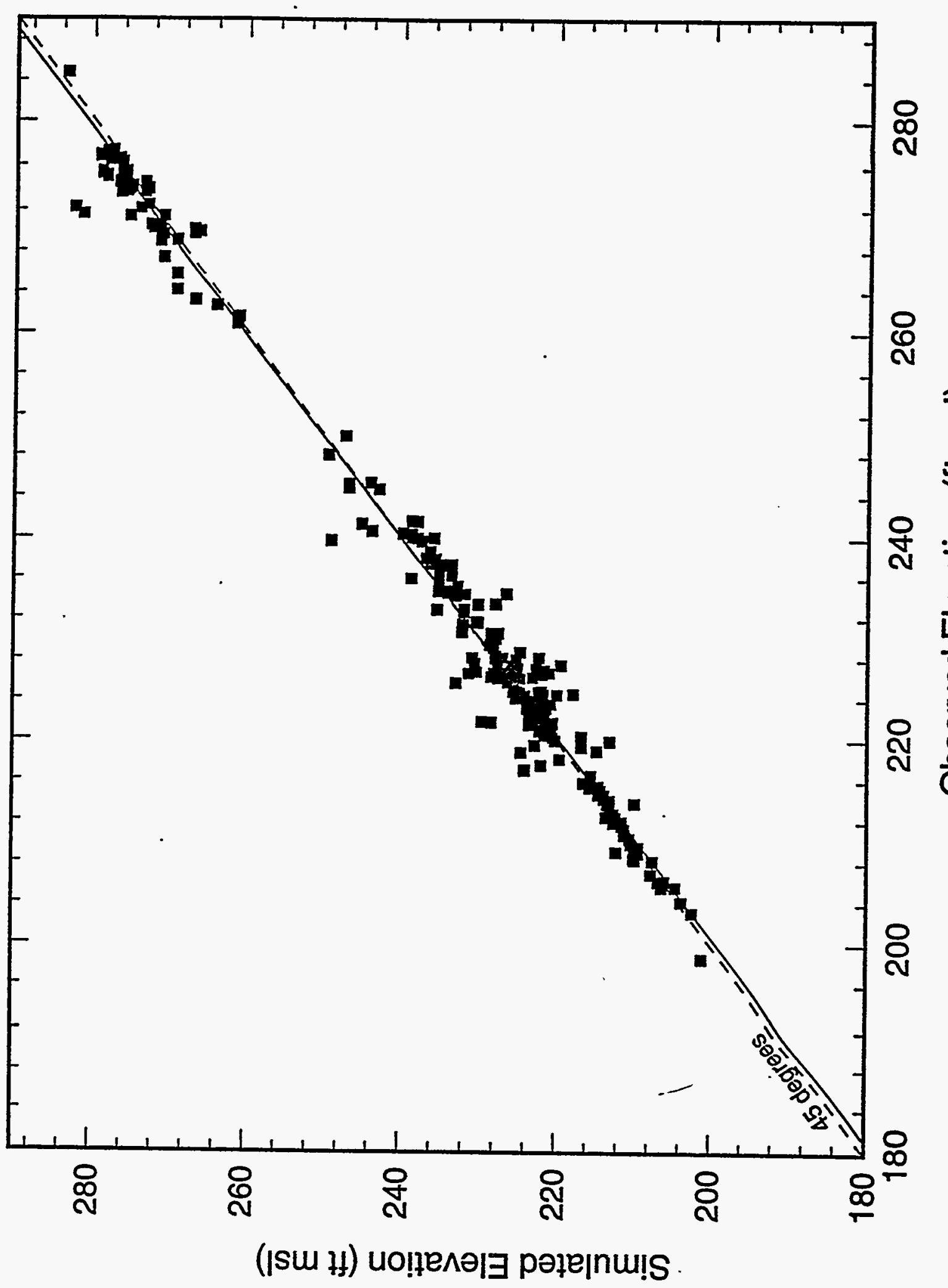




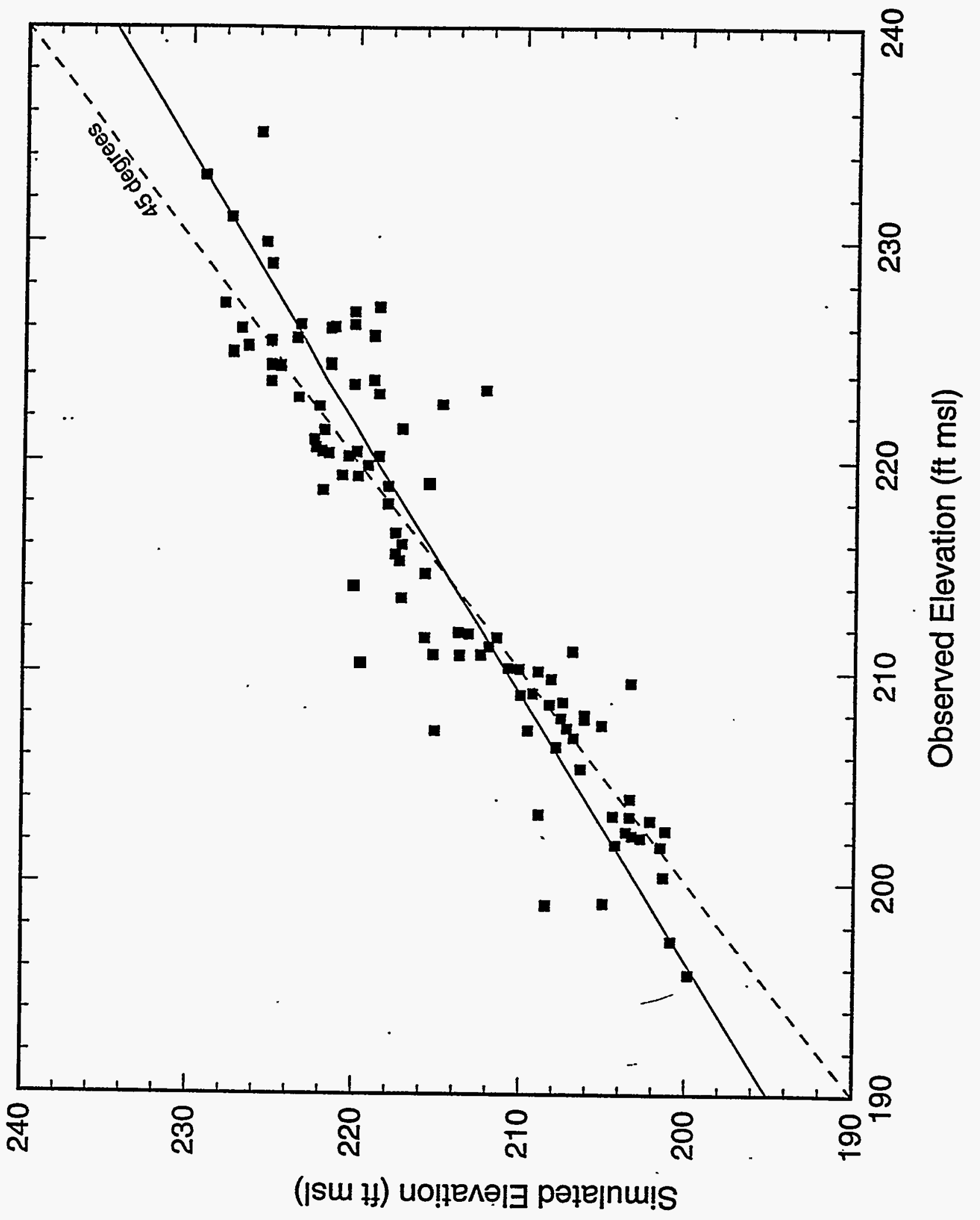

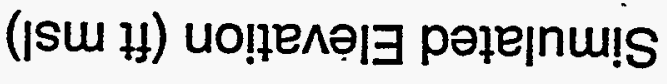




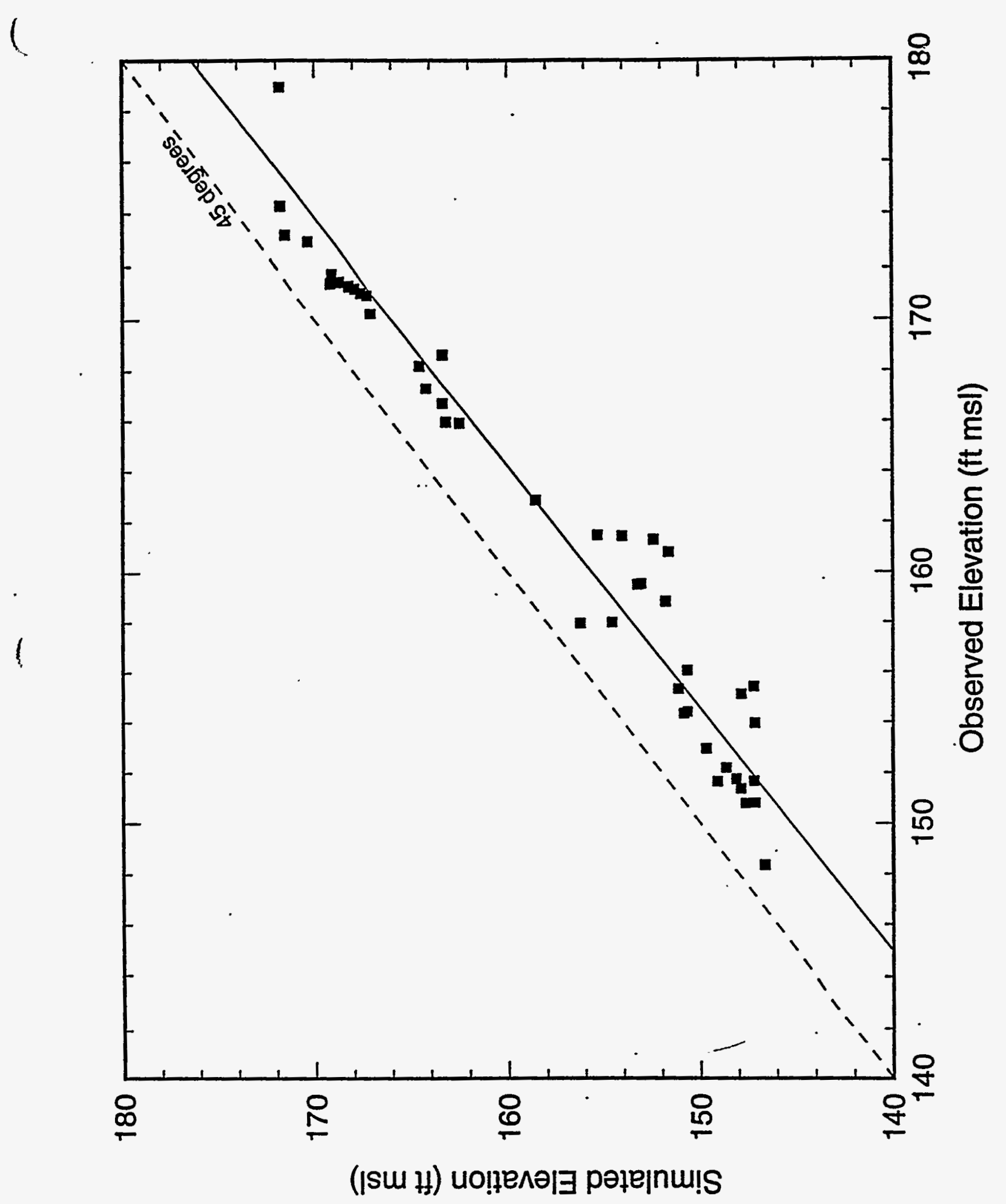




\section{APPENDIX 3 \\ SIMULATED TRITIUM CONCENTRATIONS FOR YEARS 1991, 1988, 1986, 1978, AND 1970}




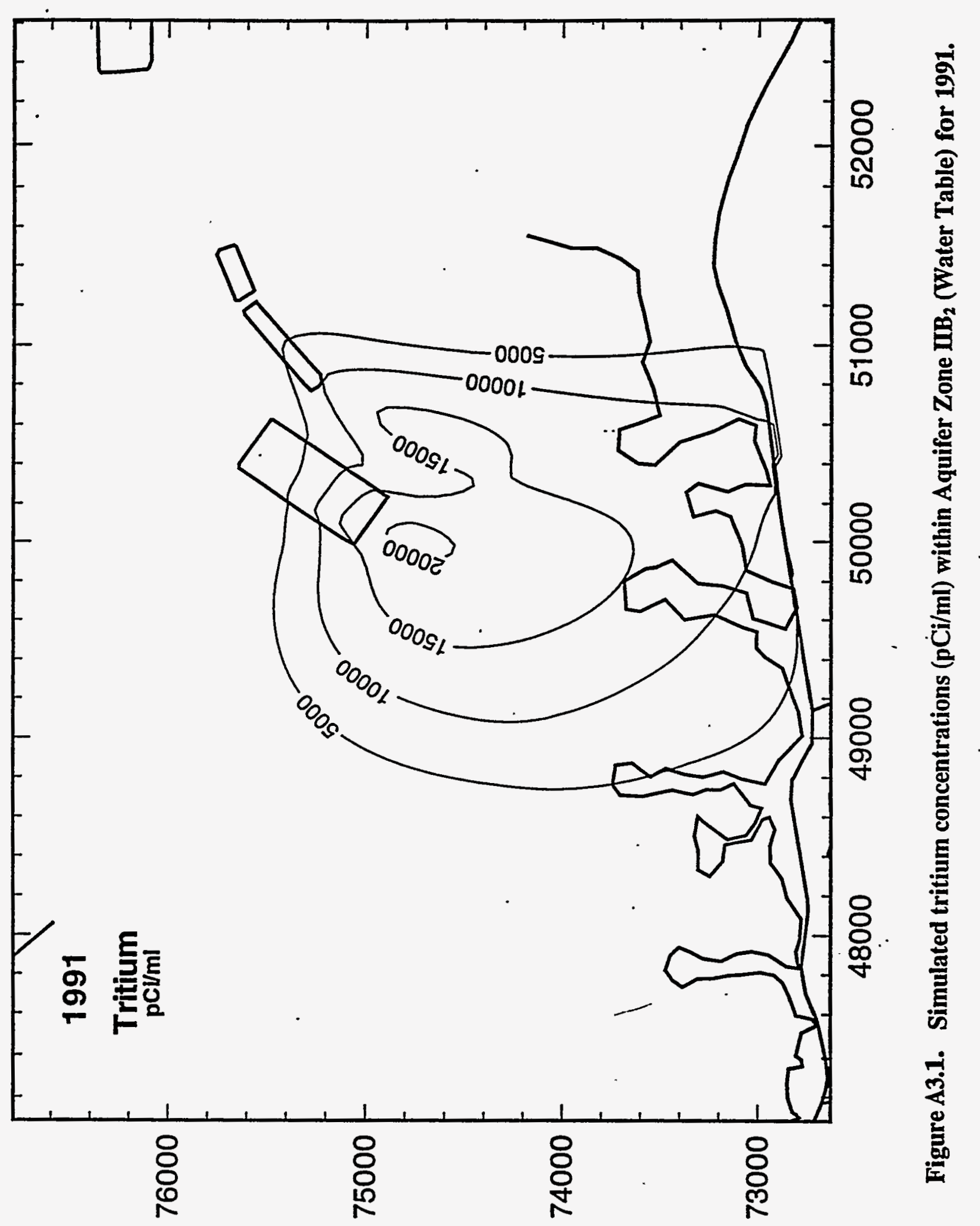




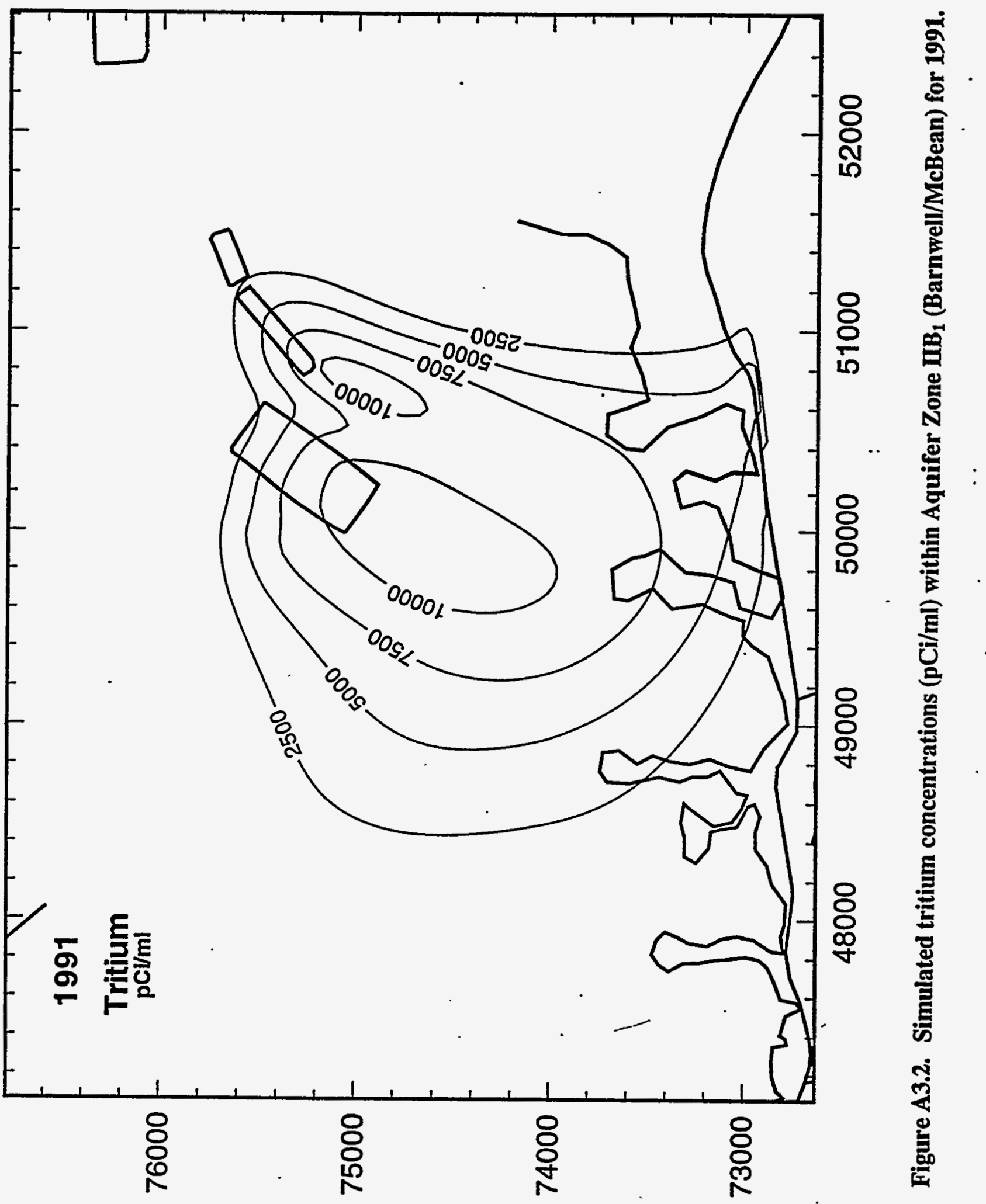




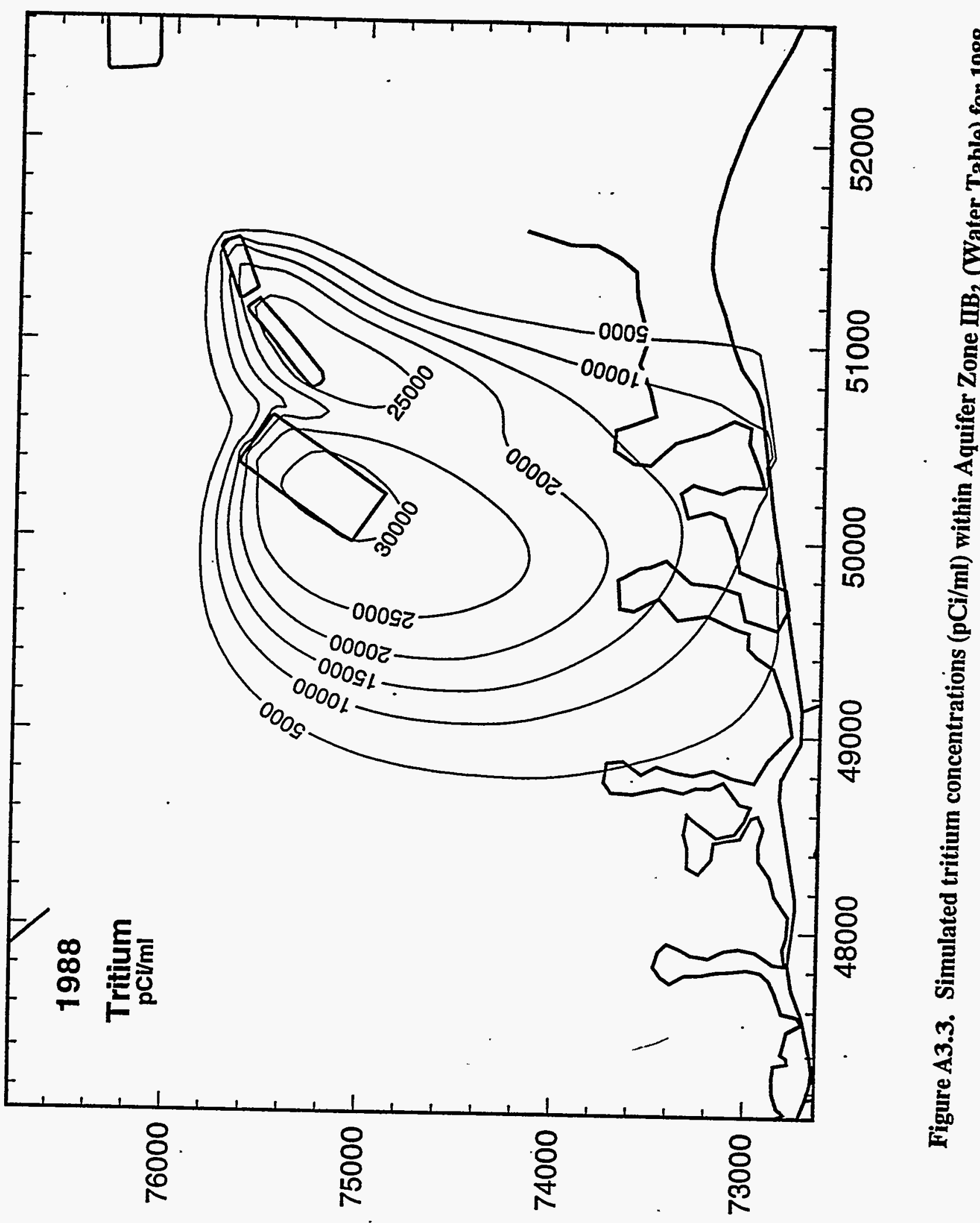




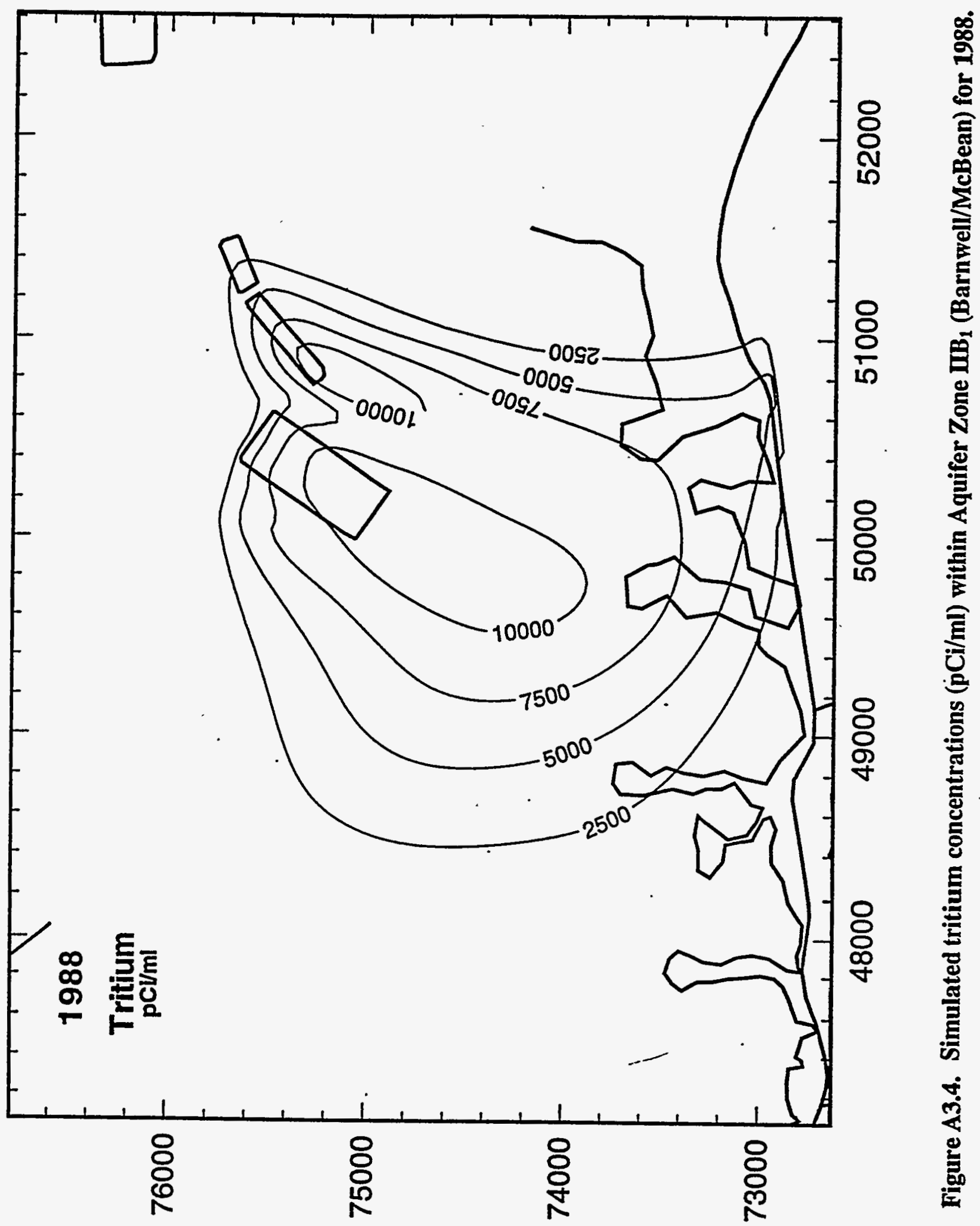




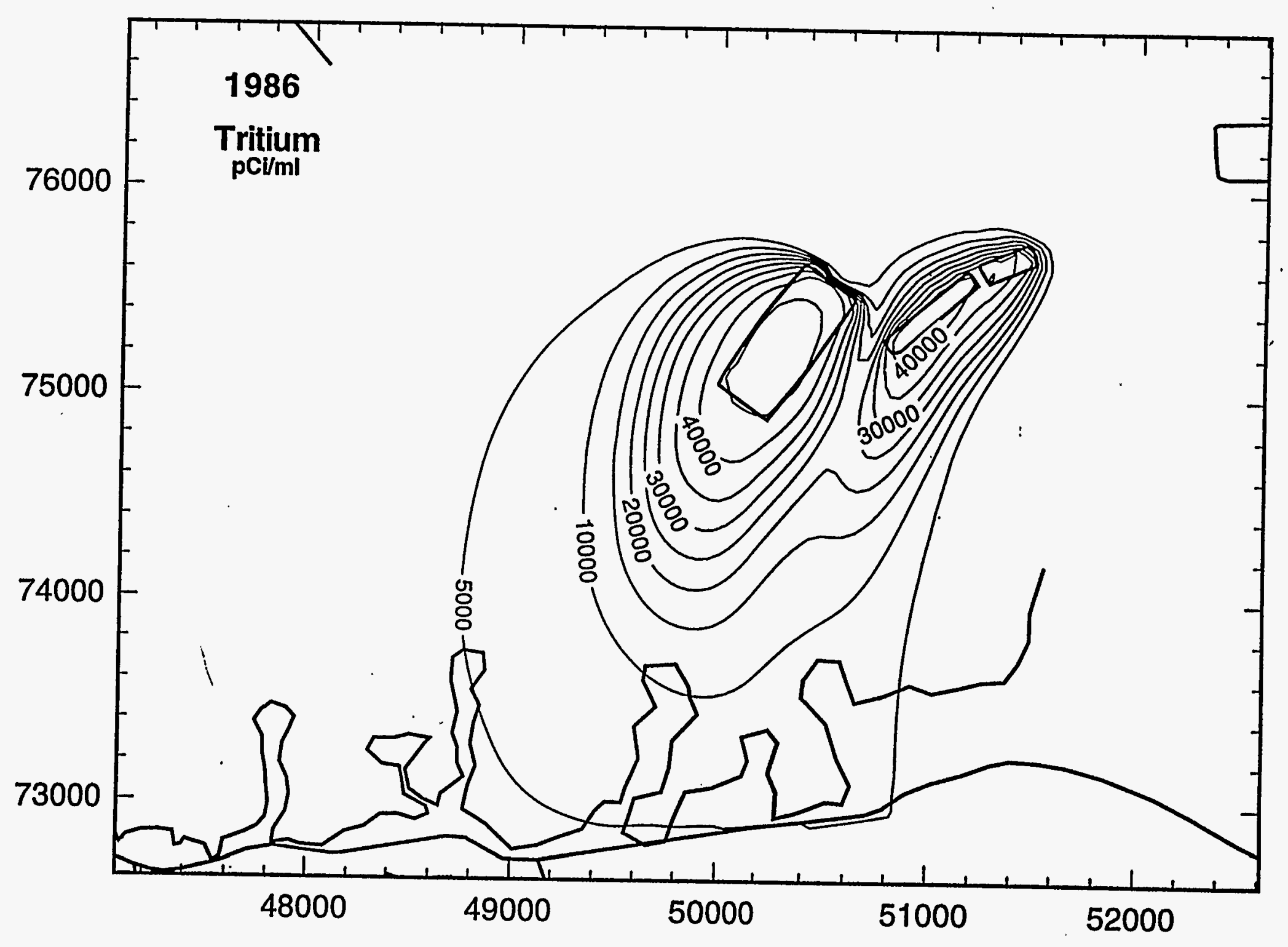

Figure A3.5. Simulated tritium concentrations (pCi/ml) within Aquifer $\mathrm{Zone}^{\mathrm{nB}} \mathrm{B}_{2}$ (Water Table) for 1986.

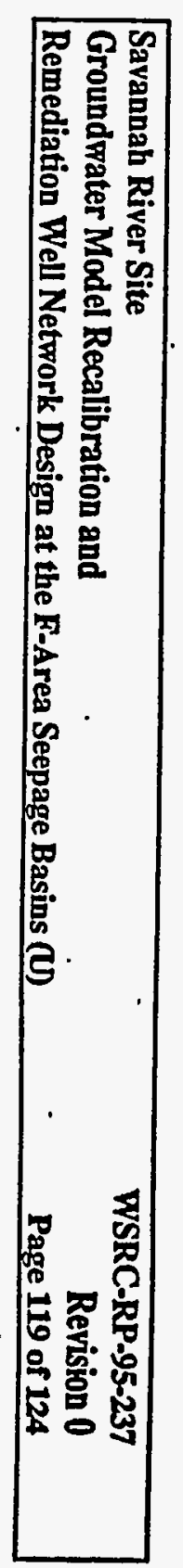




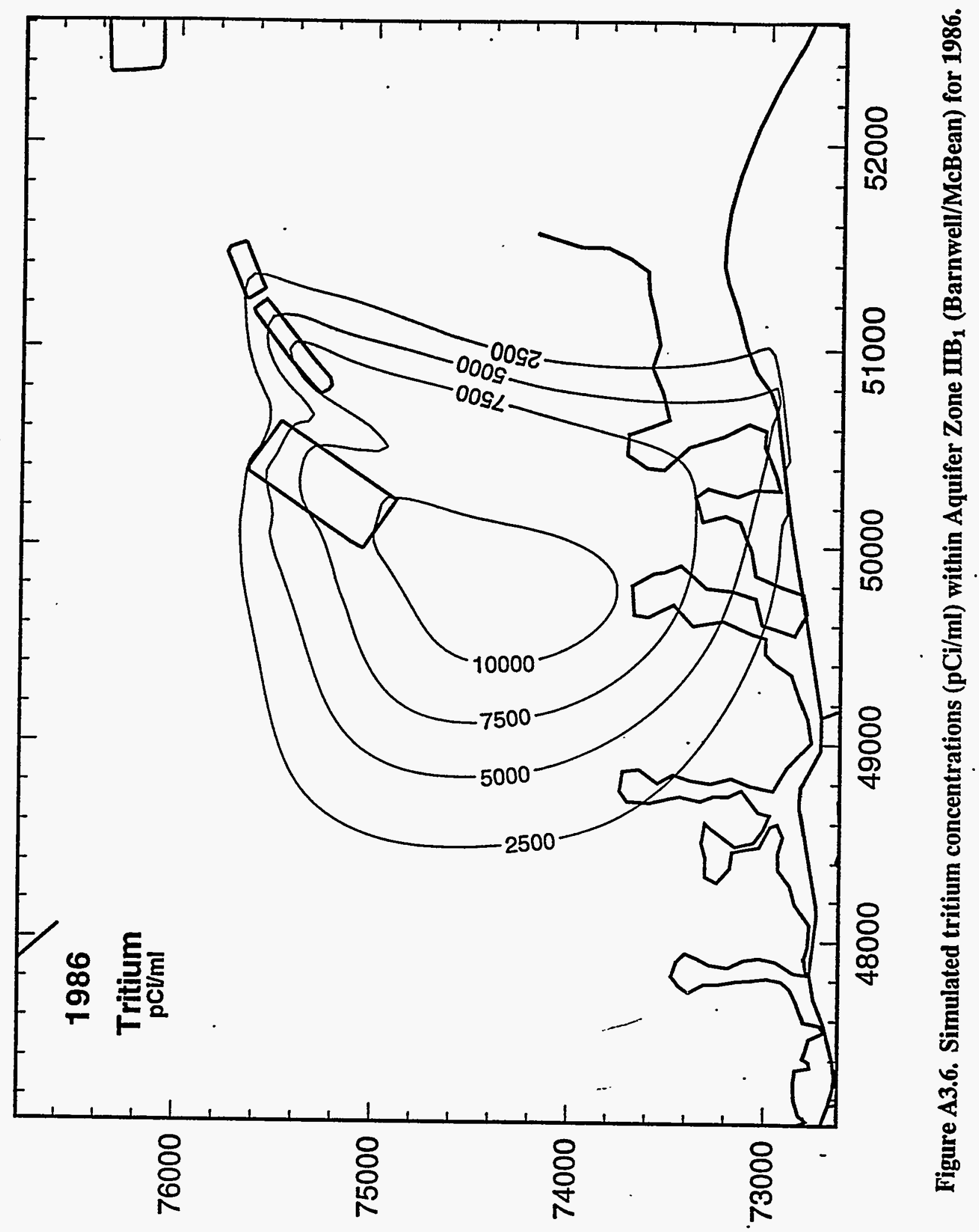




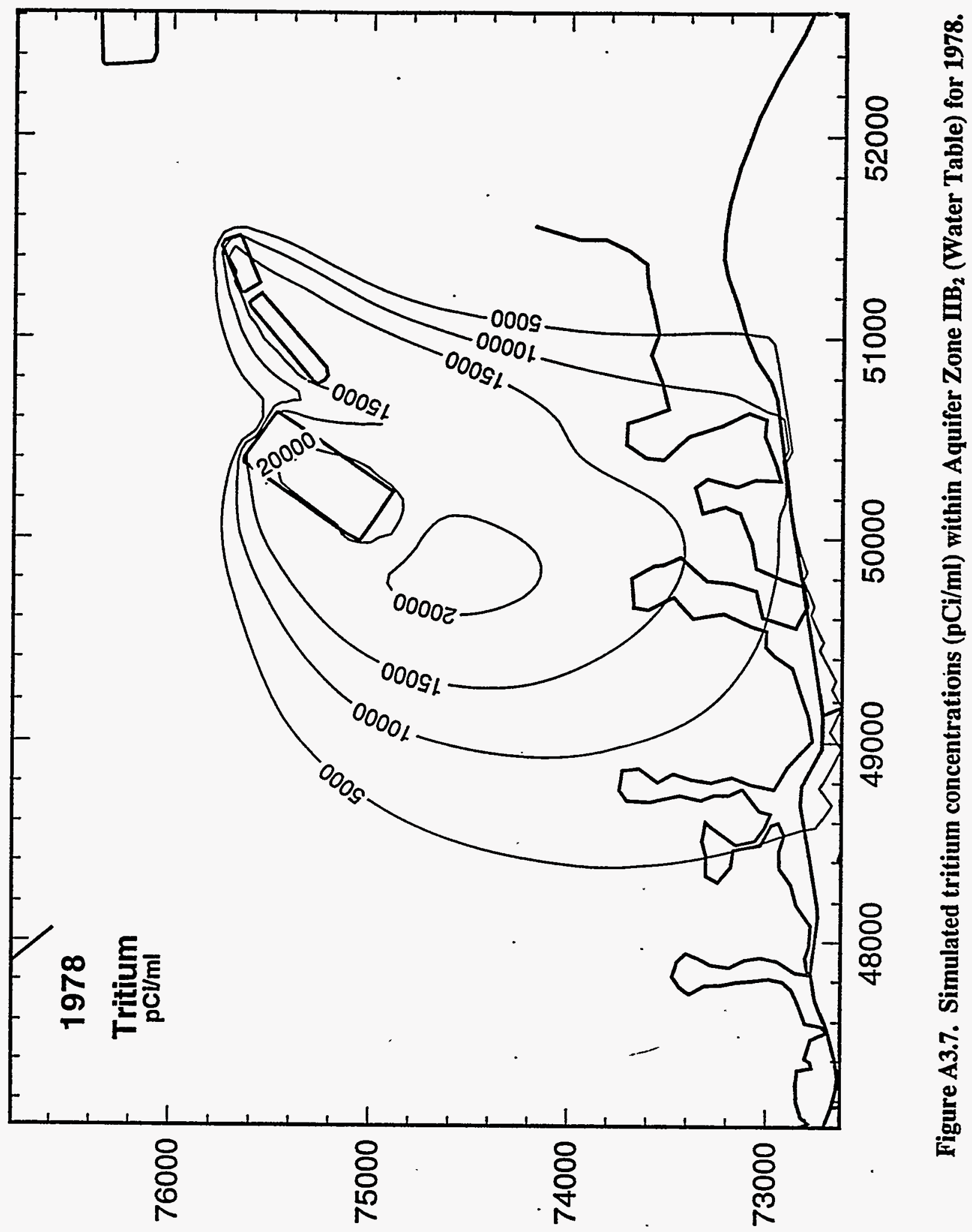



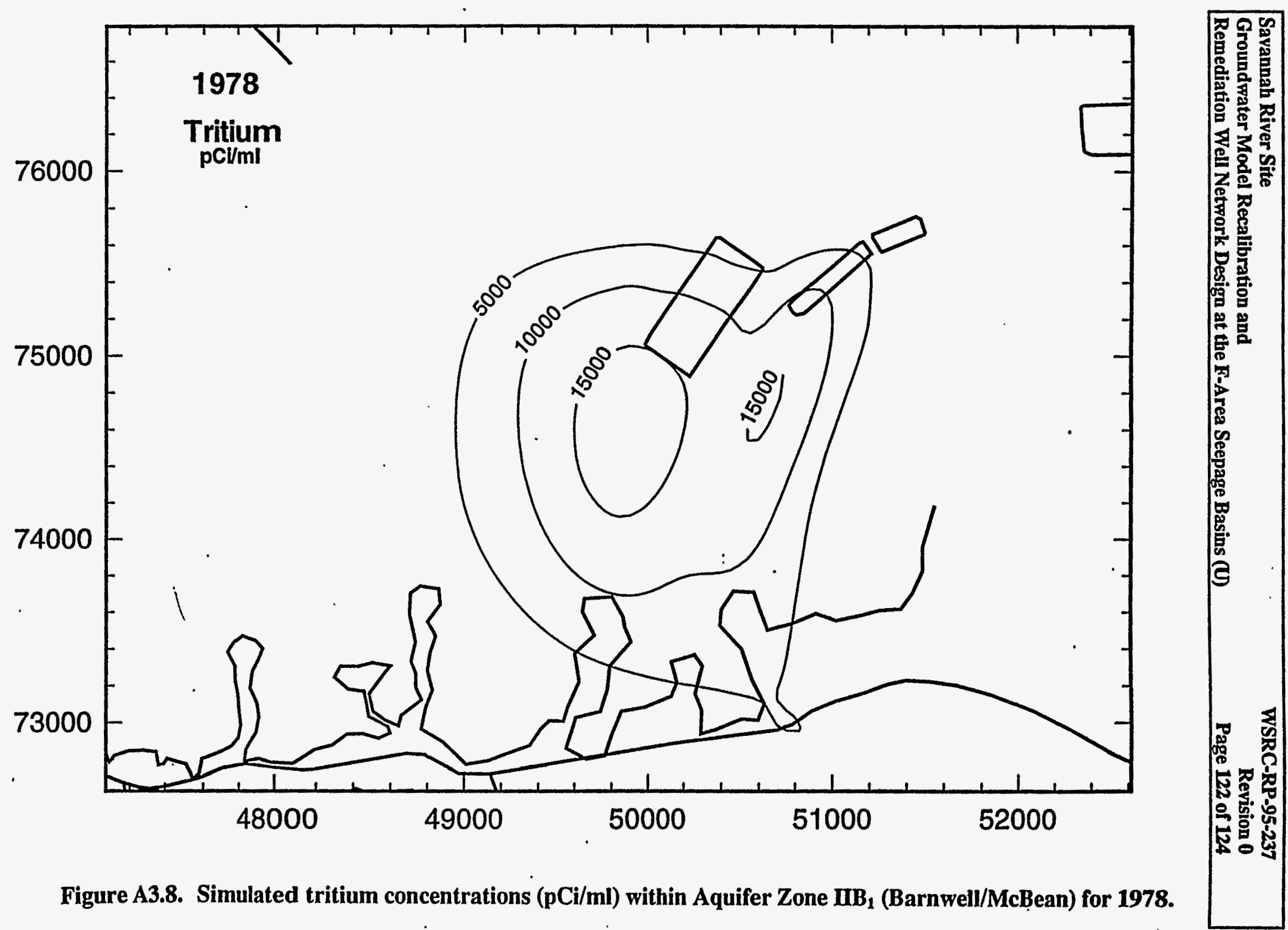

Figure A3.8. Simulated tritium concentrations ( $\mathrm{pCi} / \mathrm{ml}$ ) within Aquifer Zone $\mathbf{H B}_{\mathbf{1}}$ (Barnwell/McBean) for 1978 . 


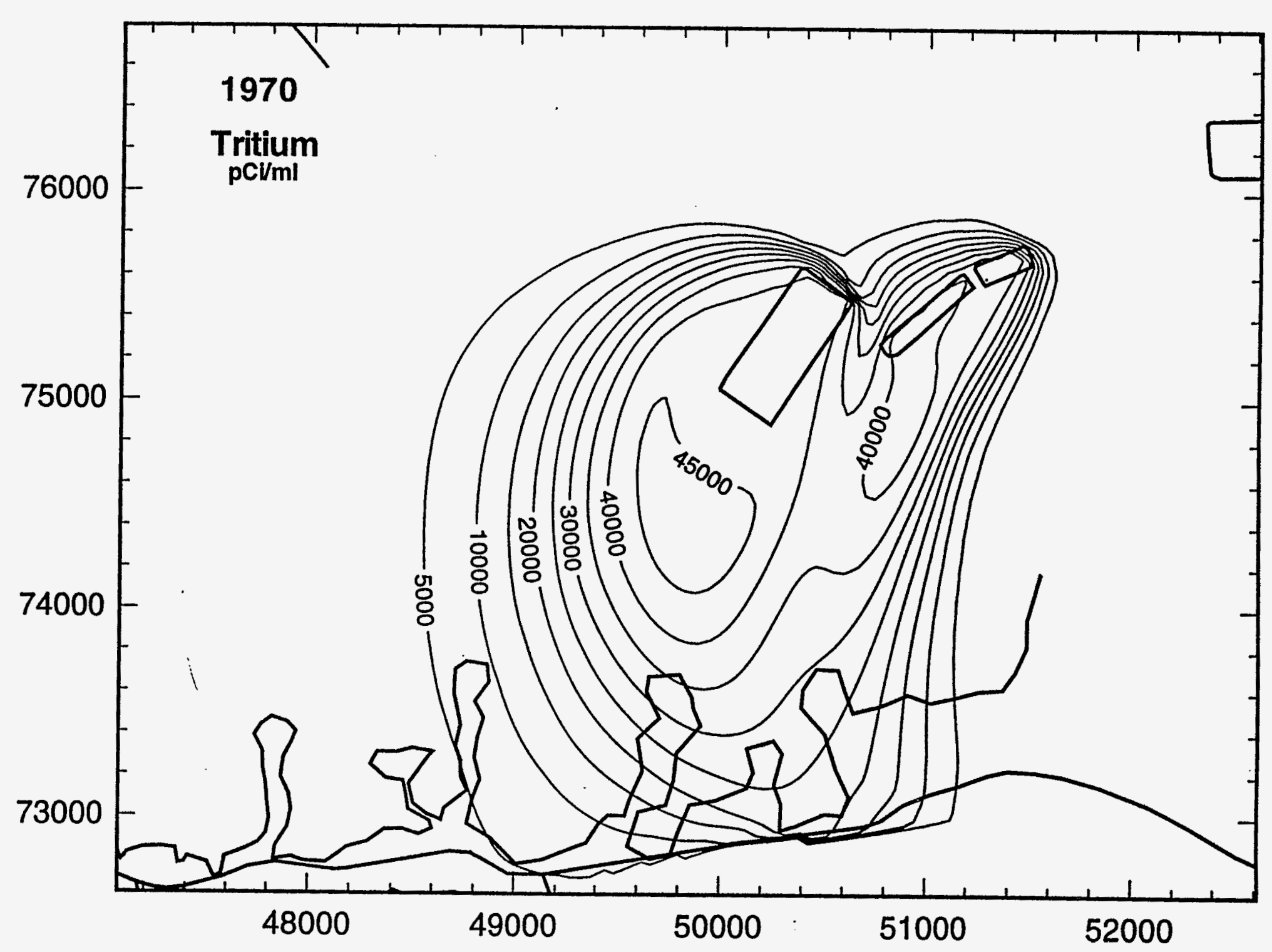

Figure A3.9. Simulated tritium concentrations $\left(\mathrm{pCi} / \mathrm{ml}\right.$ ) within Aquifer $\mathrm{Zone}^{1 \mathrm{IB}_{2}}$ (Water Table) for 1970. 


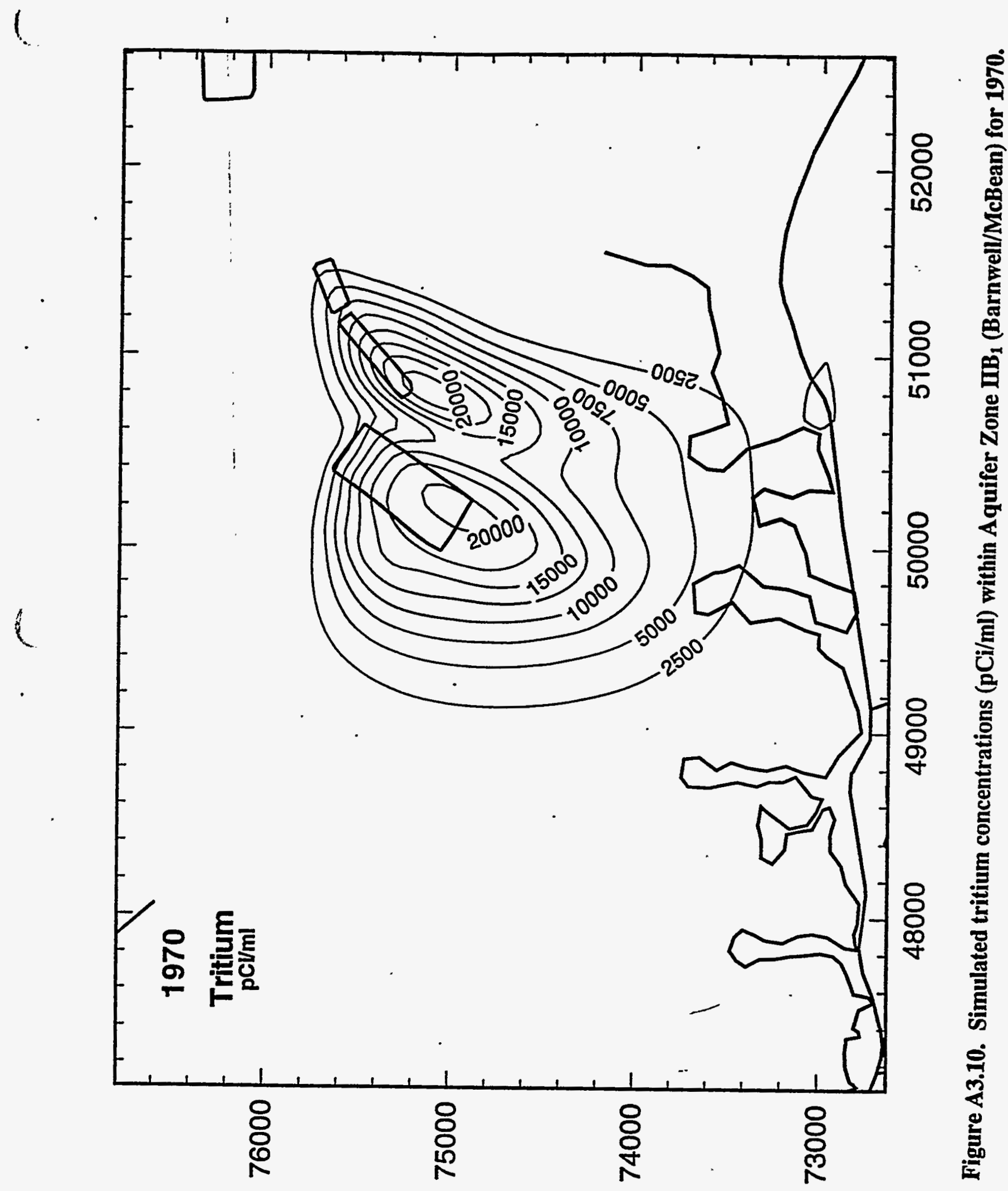

